Historic, Archive Document

Do not assume content reflects current scientific knowledge, policies, or practices. 



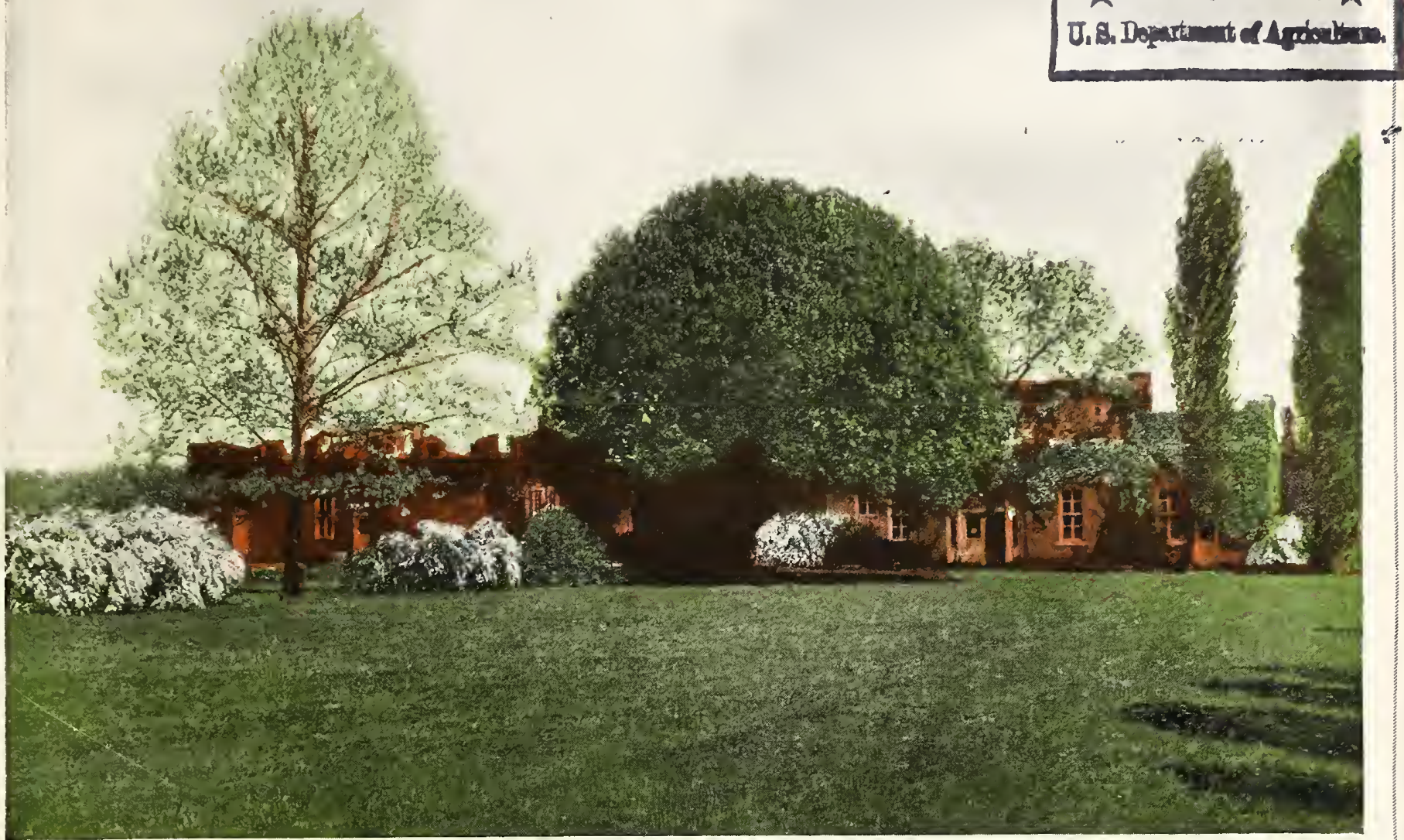

Front view of Office and Packing House. Spirea in full bloom.

Trees are Sycamore, White Ash, Black Walnut and Lombardy Poplars.
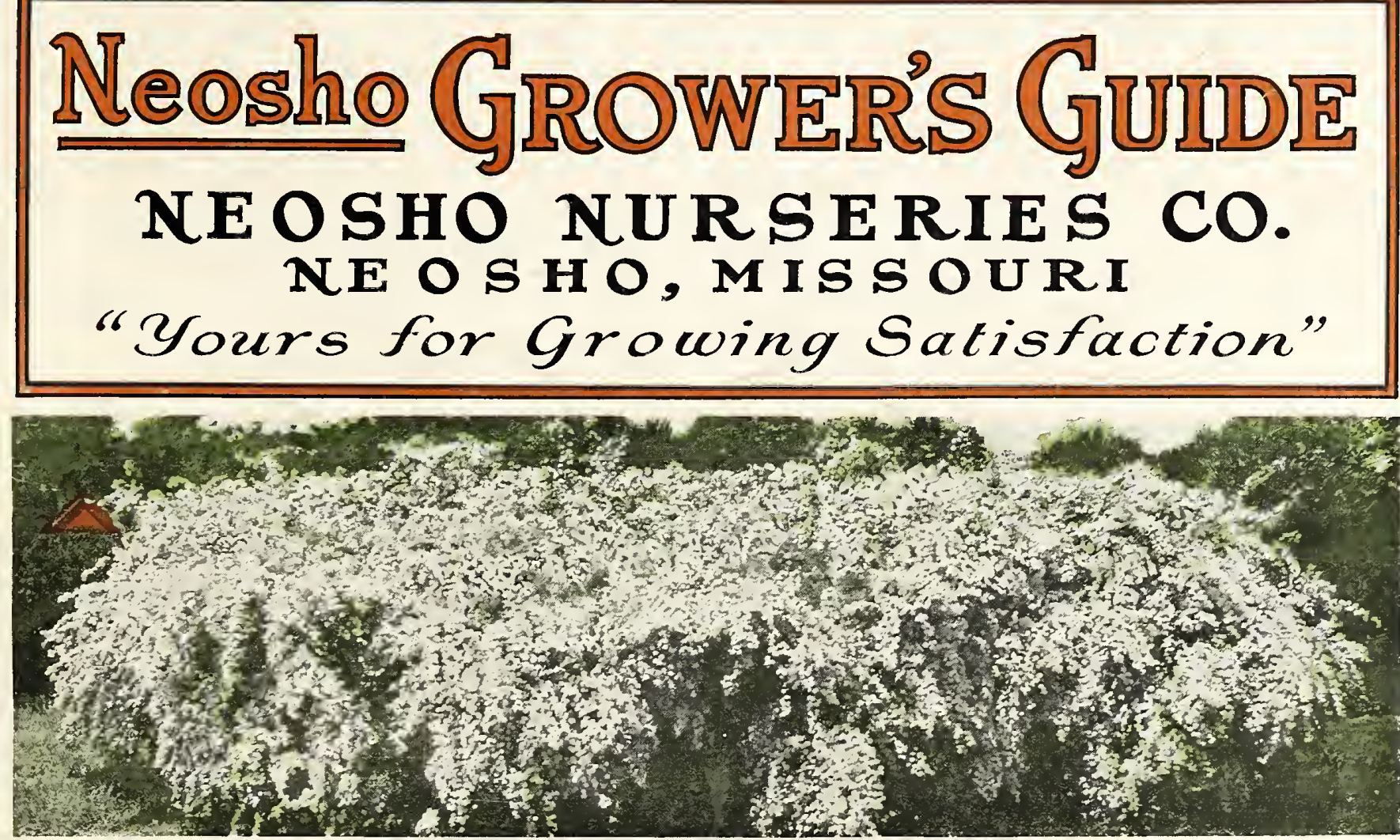

Spirea Van Houttei in all its glory-On our lawn. 


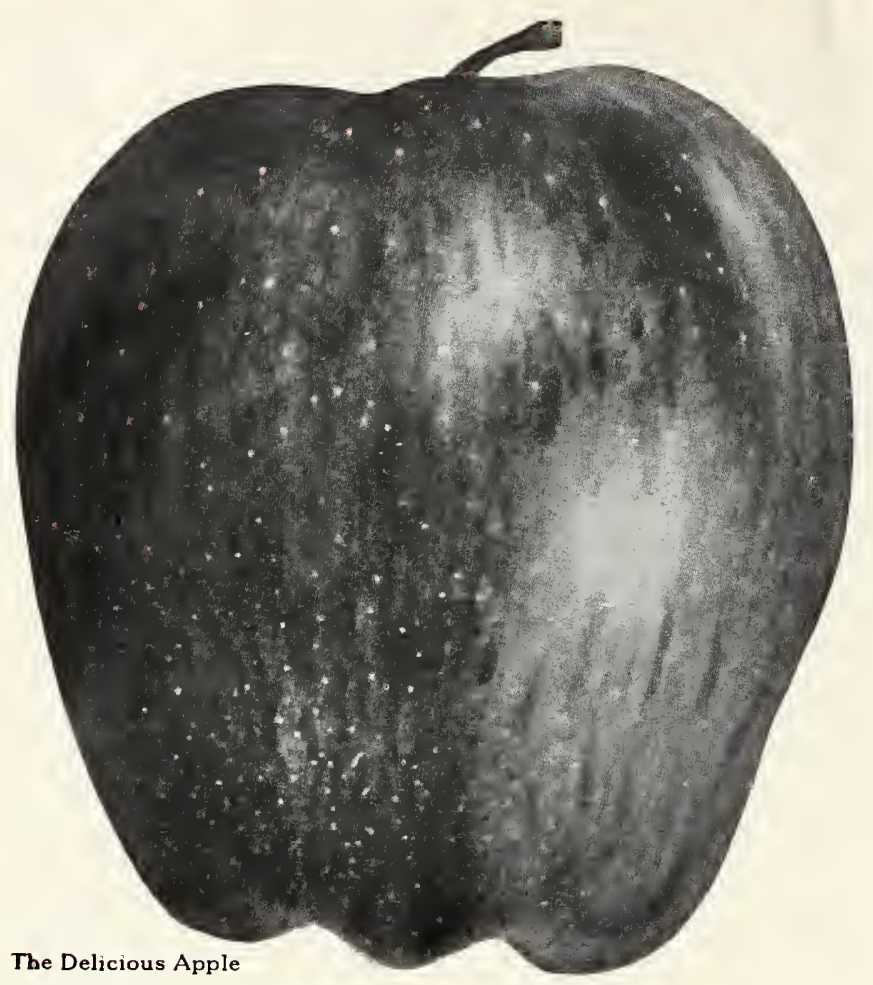

\section{or Flowers}

TOW good the taste of fruit picked fresh and fully ripe! Many people never realize it. Yet it is comparatively easy to attain. It only requires some thought, a little labor and surprisingly little money.

Most everybody has room for at least a few grape vines, trained over a trellis, wall, fence or on a building. They are attractive, too.

If you are looking for profit in fruit growing you can find it, as many others do.

But in any case your success depends chiefly upon yourself. When you buy such things as a pair of gloves, or an automobile, you get the benefit and satisfaction of their use at once. But with nursery stock, with few exceptions, perfection of fruit, foliage or flower comes only with time plus some care and attention. Your rewards will be in proportion to your careful thought in planning, to your insistence in securing trustworthy trees or plants, and to your thoughtful care of them after they reach you.

The same is true with making one's home more attractive and more valuable with ornamental trees and plants. Many hesitate because they do not realize how much can be accomplished with a few well-chosen, well-placed shrubs, vines or trees.

We hope this book will help you to enjoy growing satisfaction.

J. H. Hale Peach 


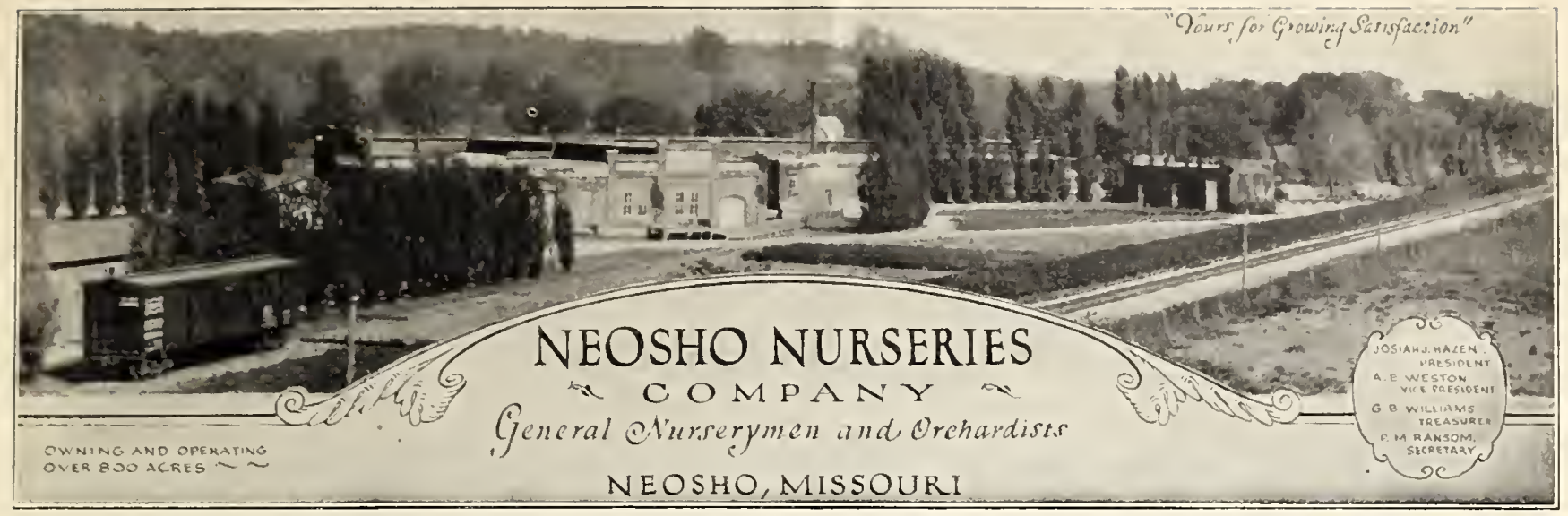

\section{A Few Words About Our Service}

\section{Your Success in Growing Fruit or Ornamentals}

depends upon many factors which we have tried to make plain and simple in these pages so that you may enjoy growing satisfaction.

\section{How to Use This Catalog}

First, you will no doubt thumb through these pages to get a general idea of the spirit of this organization. Then possibly you will turn to the index on page 48 which tells where you will find the things in which you are particularly interested.

\section{Prices}

Prices are printed separately because it is more convenient for you and because we print enough catalogs (or Grower's Guides) to use two seasons, thus effecting a considerable saving in printing cost.

\section{What Makes a Good Tree or Plant}

Nursery stock is difficult to describe because different kinds and varieties vary so much in habits of growth. But diameter of trunk and character of top can, in most instances, be stated. No one can describe vitality or trueness-to-name. These will be present only if the Nursery has the ability and the desire to provide them.

\section{Our Advantages}

Here in the Ozarks, 1,200 ft. above sea level, ten miles east of Neosho we have about 600 acres of deep fertile soil which is peculiarly adapted to growing most sorts of nursery stock. This Hagerstown loam occurs in limited areas and land a few miles distant does not produce such well-rooted sturdy stock.

We also have a long growing season and short winters although zero temperatures or below are experienced at intervals.

\section{Insurance of Quality and Vitality}

Our stock is carefully graded or sorted in a concrete building at our nursery fields and is then put into our up-to-date warehouse in Neosho where it is held at the right degree of temperature and moisture. From the time of digging up to the shipping of your order there is no chance for loss of vitality from exposure to drying sun or winds nor from freezing.

\section{Our Facilities}

Our five acre Test Orchard of fruit trees and about twenty acres of Grapes are a valuable check on varieties. We also have a young commercial apple orchard of eighteen acres. Our brick office and warehouse at Neosho covers 37,000 square feet. Here we have also a few acres in Evergreens, peonies, iris, etc.

\section{Who Buys Our Stock}

Three railroads serve Neosho-The Frisco, The Kansas City Southern and the Missouri \& North Arkansas. A spur track of the K. C. S. Railway comes to our warehouse. Our stock is shipped in car lots, and in small lots by freight, express and Parcel Post to other nurserymen and to planters who appreciate first class trees and plants.

\section{Organization}

The people who propagate, grow, handle and pack your order in the field, in the packing house and in the office have years of experience in this business and, I am proud to say, are not only skilled and interested, but are actuated by a keen desire to please the customer. So that our friends in nearly every state testify that we chose the right slogan :

"Yours for Growing Satisfaction,"

NEOSHO NURSERIES CO.
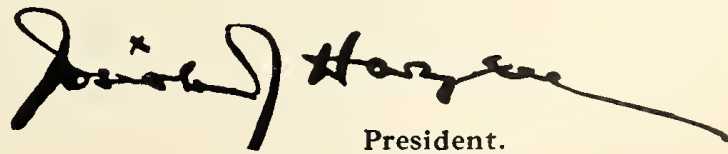


\section{Growers in Every State Endorse Neosho Stock Wherever the Variety Succeeds Neosho Trees Thrive}

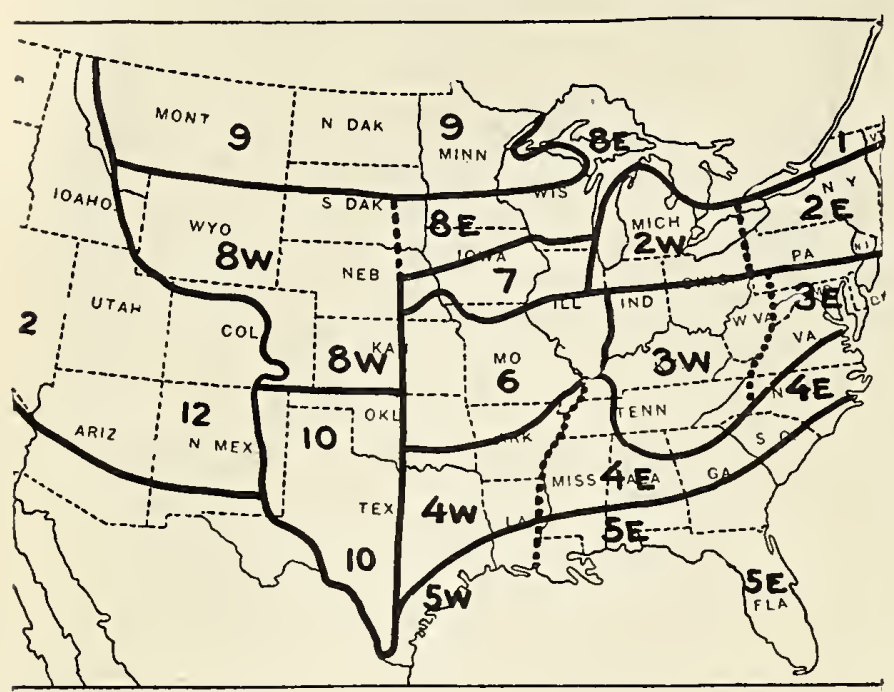

\section{What Varieties to Plant}

This map shows the fruit districts of the United States. In the tables a star indicates that the variety is known to succeed, two stars indicate the most dependable.

It is advisable to consult with any of your neighbors who may have had experience in fruit-growing in your locality. Your State Experiment Station will also be glad to give you the benefit of their investigations.

The varieties are listed in their approximate order of ripening.

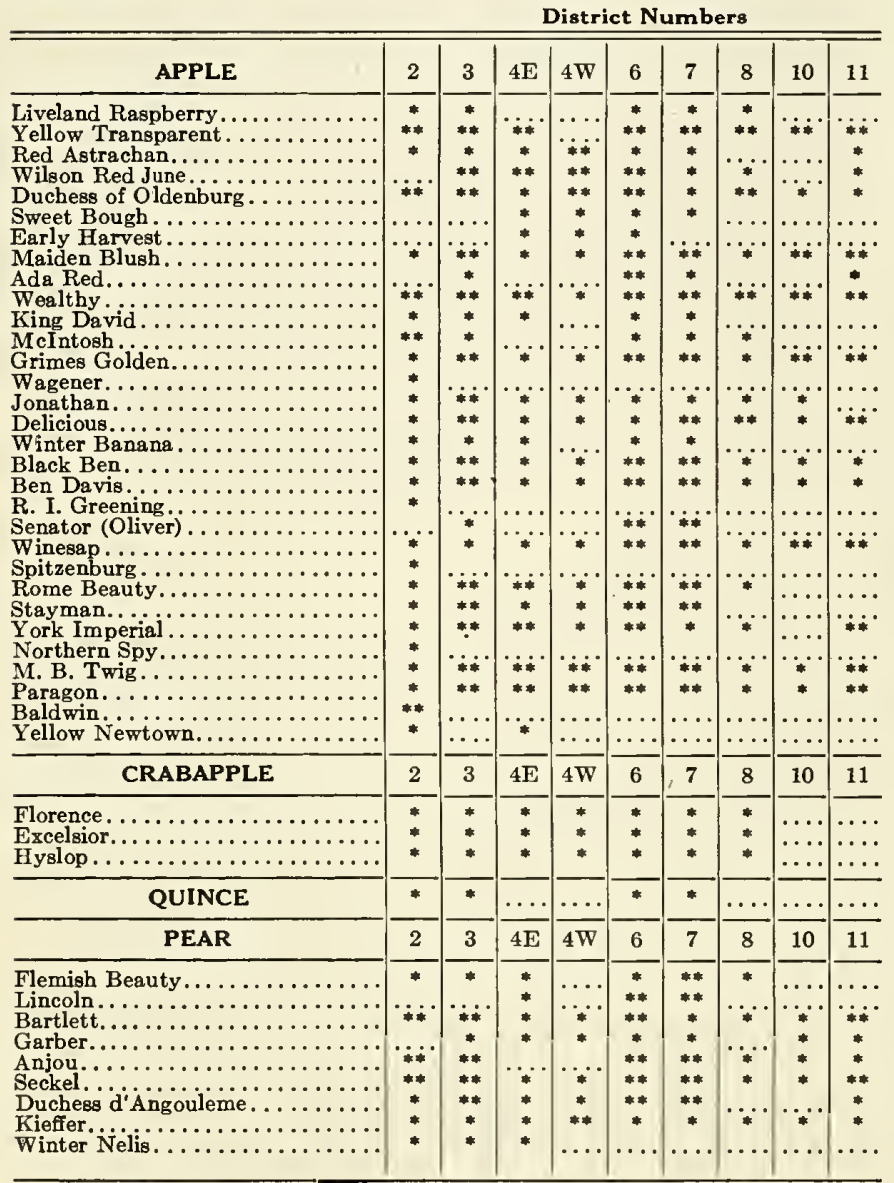

\begin{tabular}{|c|c|c|c|c|c|c|c|c|c|}
\hline \multirow[b]{2}{*}{ PEACH } & \multicolumn{9}{|c|}{ District Numbers } \\
\hline & 2 & 3 & $4 \mathrm{E}$ & $4 \mathrm{~W}$ & 6 & 7 & 8 & 10 & 11 \\
\hline 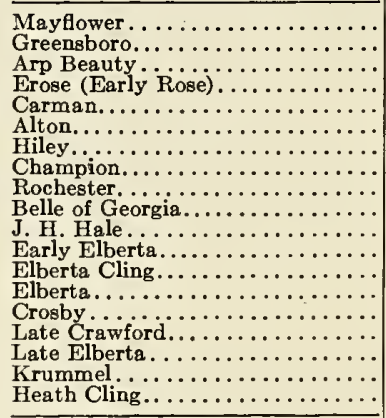 & $\begin{array}{c}\because * \\
\cdots * \\
\cdots * \\
* \\
\cdots \\
\cdots \\
\cdots \\
\cdots \\
* \\
* \\
* \\
* * \\
* \\
\cdots \\
\cdots \\
\cdots\end{array}$ & $\begin{array}{c}* \\
* * \\
* \\
* \\
* \\
* * \\
* * \\
* \\
* \\
* \\
* \\
* \\
* * \\
* \\
*\end{array}$ & $\begin{array}{c}* \\
* * \\
* * \\
* * \\
* * \\
* \\
* * \\
\cdots \\
\cdots \\
* \\
* \\
* \\
\cdots \\
\cdots \\
\cdots \\
\cdots \\
\cdots\end{array}$ & $\mid \begin{array}{l}\cdots \\
\cdots \\
\cdots \\
\cdots \\
\cdots \\
\cdots \\
\cdots \\
\cdots \\
\cdots \\
\cdots \\
\cdots \\
\cdots \\
\cdots \\
\cdots \\
\cdots\end{array}$ & $\begin{array}{l}* \\
* * \\
* * \\
* * \\
* * \\
* * \\
* * \\
* \\
* * \\
* * \\
* * \\
* \\
* \\
* \\
* \\
* \\
*\end{array}$ & $\begin{array}{l}*: * \\
* * \\
* * \\
* * \\
* * \\
* * \\
* * \\
* * \\
* * \\
* * \\
* \\
* \\
* * \\
* \\
* \\
* \\
*\end{array}$ & $\begin{array}{c}\cdots \\
\cdots \\
\cdots \\
\cdots \\
\cdots \\
\cdots \\
\cdots \\
\cdots \\
\cdots \\
\cdots \\
* \\
* \\
* \\
\cdots\end{array}$ & $\begin{array}{c}* \\
* * \\
* \\
* * \\
\ldots \\
\cdots \\
\cdots \\
* \\
* \\
* \\
* * \\
* \\
* \\
\cdots \\
* \\
* \\
* \\
* \\
*\end{array}$ & 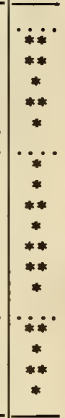 \\
\hline PLUM & 2 & 3 & $4 \mathrm{E}$ & $4 \mathrm{~W}$ & 6 & 7 & 8 & 10 & 11 \\
\hline 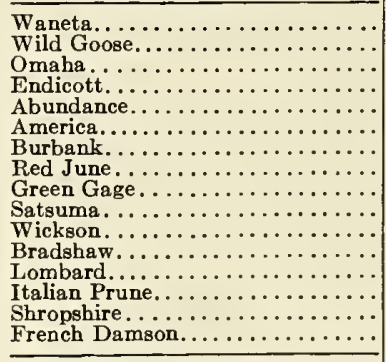 & $\begin{array}{l}\cdots \\
* \\
* \\
* \\
* \\
* \\
* * \\
* \\
* \\
* \\
* \\
* \\
* \\
*\end{array}$ & $\begin{array}{c}\cdots \\
* \\
* \\
* * \\
* \\
* \\
* \\
\cdots \\
\cdots \\
* \\
* \\
* \\
* \\
\end{array}$ & $\begin{array}{c}\because * \\
\cdots \\
\cdots * \\
* * \\
* * \\
* \\
\cdots \\
\cdots \\
\cdots \\
\cdots \\
* \\
*\end{array}$ & $\begin{array}{c}\because * \\
\cdots \\
\cdots * \\
* \\
* \\
\cdots \\
\cdots \\
\cdots \\
\cdots \\
\cdots \\
\cdots \\
\cdots \\
\cdots \\
\end{array}$ & \begin{tabular}{|c|}
$*$ \\
$*$ \\
$* *$ \\
$* *$ \\
$* *$ \\
$* *$ \\
$*$ \\
$\cdots$ \\
$\cdots$ \\
$\cdots$ \\
$* *$ \\
$* *$ \\
$* *$ \\
\end{tabular} & $\begin{array}{c}* \\
* * \\
* * \\
* * \\
* * \\
* * \\
\cdots \\
\cdots \\
\cdots \\
\cdots \\
* * \\
* * \\
* * \\
\end{array}$ & 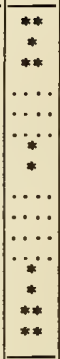 & $\begin{array}{c}\because \cdots \\
\cdots \\
\cdots \\
\cdots \\
\cdots \\
\cdots \\
\cdots \\
\cdots \\
\cdots \\
\cdots \\
\cdots \\
\cdots \\
\cdots \\
\cdots\end{array}$ & {$\left[\begin{array}{c}\because \\
\cdots \\
\cdots \\
\cdots \\
\cdots \\
\cdots \\
\cdots \\
\cdots \\
\cdots \\
\cdots \\
\cdots \\
\cdots \\
\cdots\end{array}\right.$} \\
\hline APRICOT, Superb & * & * & * & $*$ & 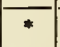 & $\bar{*}$ & $\ldots$ & 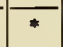 & $\ldots$ \\
\hline CHERRY & 2 & 3 & $4 \mathrm{E}$ & $4 \mathrm{~W}$ & 6 & 7 & 8 & 10 & 11 \\
\hline 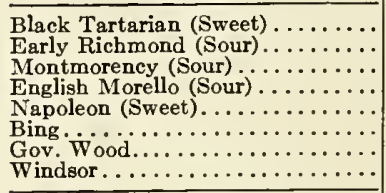 & \begin{tabular}{c|}
$*$ \\
$* *$ \\
$* *$ \\
$* *$ \\
$*$ \\
$*$ \\
$*$
\end{tabular} & $\begin{array}{c}* \\
* \\
* * \\
* * \\
\cdots \\
\cdots \\
\cdots \\
\cdots\end{array}$ & $\left(\begin{array}{c}\cdots \\
* \\
\cdots \\
\cdots \\
\cdots \\
\cdots\end{array}\right.$ & $\begin{array}{l}\cdots \\
\cdots \\
\cdots \\
\cdots \\
\cdots \cdots \\
\cdots \cdots \\
\cdots\end{array}$ & \begin{tabular}{c|}
$*$ \\
$* *$ \\
$* *$ \\
$* *$ \\
$*$ \\
$\cdots$ \\
$\cdots$ \\
$\cdots$ \\
\end{tabular} & \begin{tabular}{c|}
$*$ \\
$* *$ \\
$* *$ \\
$*$ \\
$\cdots$ \\
$\cdots$ \\
$\cdots$ \\
$\cdots$
\end{tabular} & $\mid \begin{array}{c}\cdots * \\
* * \\
* \\
* \\
\cdots \\
\cdots \\
\cdots\end{array}$ & $\begin{array}{c}\because * \\
* * \\
\cdots \cdots \\
\cdots \cdots \\
\cdots \cdots \\
\cdots \cdots \\
\cdots \cdots\end{array}$ & $\begin{array}{l}\cdots \\
\cdots * \\
\cdots \\
\cdots \\
\cdots \cdots \\
\cdots \cdots \\
\cdots \cdots\end{array}$ \\
\hline GOOSEBE & 2 & 3 & $4 \mathrm{E}$ & $4 \mathrm{~W}$ & 6 & 7 & 8 & 10 & 11 \\
\hline Oregon Champion........... & * & * & $\cdots$ & $\cdots$ & * & * & * & * & * \\
\hline CURRANT & 2 & 3 & $4 \mathrm{E}$ & $4 \mathrm{~W}$ & 6 & 7 & 8 & 10 & 11 \\
\hline $\begin{array}{l}\text { London Market........... } \\
\text { Perfection................ } \\
\text { White Grape......... }\end{array}$ & ** & $\because *$ & $\cdots \cdots$ & 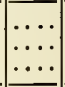 & $*$ & ** & * & * & $\cdots$ \\
\hline GRAPE & 2 & 3 & $4 \mathrm{E}$ & $4 \mathrm{~W}$ & 6 & 7 & 8 & 10 & 11 \\
\hline 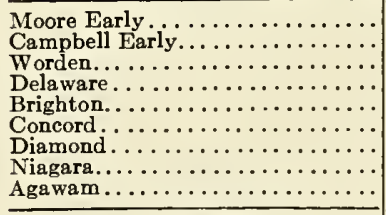 & $\begin{array}{c}* \\
* * \\
* * \\
* \\
* * \\
* * \\
* * \\
\cdots \\
\end{array}$ & $\begin{array}{l}* * \\
* \\
* * \\
* * \\
* \\
* * \\
* \\
* \\
* \\
\end{array}$ & $\begin{array}{l}* * \\
* \\
* \\
* \\
* * \\
* * \\
*\end{array}$ & $\begin{array}{c}* \\
* \\
* \\
* \\
* \\
* \\
* \\
\cdots\end{array}$ & $\begin{array}{l}* * \\
* * \\
* * \\
* * \\
* * \\
* * \\
*\end{array}$ & $\begin{array}{l}* * \\
* \\
* * \\
* \\
* \\
* \\
* * \\
* *\end{array}$ & $\begin{array}{l}* \\
* \\
* \\
* \\
*\end{array}$ & $\begin{array}{c}\cdots \cdots \\
\cdots \cdots \\
\cdots \\
\cdots \\
\cdots \\
\cdots \\
\cdots \\
\cdots\end{array}$ & $\begin{array}{l}\ldots \ldots \\
\cdots \cdots \\
\cdots \cdots \\
\cdots \cdots \\
\cdots \cdots \\
\cdots \cdots \\
\cdots \cdots \\
\end{array}$ \\
\hline BLACKBERRY & 2 & 3 & $4 \mathrm{E}$ & $4 \mathrm{~W}$ & 6 & 7 & 8 & 10 & 11 \\
\hline Eldorado.................... & $\because \cdots$ & * & $\begin{array}{c}* * \\
\cdots \\
\cdots \\
\end{array}$ & $\begin{array}{c}* * \\
* \\
\cdots\end{array}$ & * & $\because \cdots$ & $\because \ldots$ & 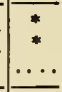 & $\cdots$ \\
\hline DEWBERRY, Lucretia & * & * & 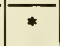 & * & * & $\cdots$ & $\ldots$ & $*$ & * \\
\hline RASPBERRY & 2 & 3 & $4 \mathrm{E}$ & $4 \mathrm{~W}$ & 6 & 7 & 8 & 10 & 11 \\
\hline 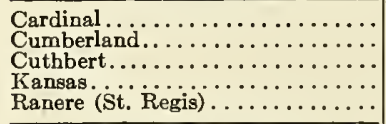 & $\cdots$ & $\begin{array}{l}\cdots \\
\cdots \\
*\end{array}$ & $\cdots$ & $\begin{array}{l}\cdots \cdots \\
\cdots \cdots \\
\cdots\end{array}$ & $\begin{array}{c}* * \\
* * \\
* * \\
*\end{array}$ & * & $\cdots$ & $\begin{array}{l}\cdots \\
\cdots \\
\cdots \\
\cdots \\
\cdots\end{array}$ & $\begin{array}{l}\cdots \\
\cdots \cdots \\
\cdots \cdots \\
\cdots \cdots\end{array}$ \\
\hline STRAWBERRY & 2 & 3 & $4 \mathrm{E}$ & $4 \mathrm{~W}$ & 6 & 7 & 8 & 10 & 11 \\
\hline 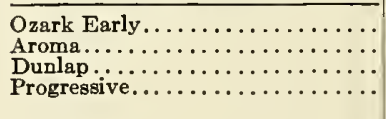 & $\because$ & $\begin{array}{c}\cdots \\
* \\
* *\end{array}$ & $\cdots$ & $\cdots$ & $\begin{array}{l}* \\
* * \\
* *\end{array}$ & $\begin{array}{l}* \\
* \\
*\end{array}$ & $\because \cdots$ & $\cdots$ & $\begin{array}{l}\cdots \\
\cdots \cdots \\
\cdots \cdots\end{array}$ \\
\hline
\end{tabular}




\section{Profit and Pleasure in the "Home Fruit Garden"}

Many people do not know how good is the taste of quality fruits picked fresh and ripe in the home garden, because they have tasted only fruits shipped in, which have to be picked before fully ripened. Furthermore, the varieties grown for the market are selected for productiveness, color, and to stand shipping rather than for high quality.

You can grow first class fruit if you will do your part. We guarantee what you order from us to be satisfactory upon arrival and will show you how to take care of it. It is a question of taking only one step at a time. (For information on varieties adapted to your district, see page 2.)

The First step is to select a location. I is better to have the fruit garden some distance from the house than to sacrifice success by planting on a poor site or soil A site that is higher than the land around it is preferable since it has better air an from frost and avoiding wet feet, which from frost and avoiding wet fee

most fruit trees and plants abhor. You could have the following in a plot 162 by 131 ht.

162 by 131 ft.: 5 Apple, 33 ft. apart, $15 \mathrm{ft}$. from the fence. Space between rows $30 \mathrm{ft}$ from the fence. Space between rows $30 \mathrm{ft}$. between row: 5 Appl

Third row: 5 Sour Cherry, 3 Peach, 20 f. apart. Space between rows $20 \mathrm{ft}$

Fourth row: 5 Plum, 1 Apricot, 2 P a

20 ft apart. Sipace between rows $15 \mathrm{ft}$.

Fifth row: $18 \mathrm{Grape} V$ ines, 8 ft. apart. Space between rows $10 \mathrm{ft}$

Sixth row: 50 Blackberry, 3 ft. apart. Srace between rows $6 \mathrm{ft}$.

Seventh row: 50 Raspberry, 3 ft. apart. Srace between rows $6 \mathrm{ft}$.

Eighth row: 100 Asparagus, 15 inches apart, and 5 Rhubarb, 2 ft. apart.

Some varieties need more room when full grown than others of same kind. Yellow Transparent, a small upright grower, and Rhode Island Greening, a large spreadin

\section{Planting Distances}

Usual Distance

Apple. . ...3 30 by $30 \mathrm{ft}-25$ to $50 \mathrm{ft}$. apart Apricot. Cherry, sweet.25 by $25 \mathrm{ft}-20$ to $30 \mathrm{ft}$. apart Cherry, Sweet. 25 by $25 \mathrm{ft}-20$ to $30 \mathrm{ft}$. apart Peach or Plum 20 by $20 \mathrm{ft} .-16$ to $20 \mathrm{ft}$. apart Peach or Plum 20 by $20 \mathrm{ft} .-16$ to $20 \mathrm{ft}$. apart Pear, Stand'rd.25 by $25 \mathrm{ft}$ - -20 to $30 \mathrm{ft}$. apart Pear, Dwarf..12 by $12 \mathrm{ft}-10$ to $15 \mathrm{ft}$. apart Plants Rows Blackberry.......2 to $5 \mathrm{ft} . \quad 5$ to $7 \mathrm{ft}$. Red Raspberry.....2 to $3 \mathrm{ft}$. 5 to $6 \mathrm{ft}$. Currant.......... Gooseberry........ Grape......... to $10 \mathrm{ft}$. $10 \mathrm{ft}$. Asparagus.........

To determine number of trees per acre for any given distance, multiply distance between trees in row by width of row Take resulting answer and divide 43,560 by it. For example: To determine number of trees, planted $30 \times 30$, required to set one per acre.

The Third Step is to send us your order first page for terms, when we can ship, etc.)

\section{Preparing the Ground}

Land that has been in some cultivated farm or garden crop is usually in the best deep and work the ground thoroughly.

An ideal soil mellow, deep, fertile loam

is not often avaliable and it may even be necessary to go to considerable trouble to imrrove the dirt you have; for instance, for fruit trees dig a hole 5 feet in diameter, throwing the surface soil to one side, then digging out the subsoil to a depth of 6 to 12 inches, putting it in a pile by itself. Then throw in a few shovelfuls of welldecayed manure. Next throw in the surface soil. In this set the tree and use other surface soil to fill the hole. The other pile of subsoil can be scattered on the surface. Well-rotted manure, wood ashes and ground bone or cottonseed meal can be mixed in with the surface soil used to fill the hole, but care should be taken to avoid having too much of any fertilizer come in and currants the holes should be about blackberries dig a trench 15 to 18 inches wide.

\section{Handling Trees on Arrival}

If possible plant at once. or bundle in a cool but frost-proof cellar. ready to weather is warm and you are not the stock in a cool cellar, covering the roots with damp packing from the box or bundle and spread old sacks or canvas or bundle and spread old sacks or canvas trees to keep them from drying out, but do not drench the roots and tops. If pos sible heel them in, preferably at the north protection from the sun and their deprotection from the sun and
velorment will be retarded.

\section{Heeling in Trees}

Select a well-drained location. Dig a trench deep enough and wide enough to hold the roots without crowding. Fine, about the roots. Then heap more soil on the roots and a third or more of the tops. Some growers completely cover the trees. If the ground is too dry moisten the dirt about the roots. Some growers get their trees in the fall and heel them in over hand when conditions are right for planting in the spring.

Treatment for "Dried Out" Trees

Sometimes trees are somewhat dried out in transit but can be restored by burying to three days.

\section{Handling Trees at Planting}

Success is largely a matter of avoiding exposure of roots and tops to the sun or the soil about the roots. Cut off any bruised or broken ends and shorten any roots that are extra long and rut the trees at once in a barrel or tub about one-fourth full of water. Some use a semi-liquid of water and dirt (not heavy clay).

\section{Setting the Trees}

Assuming that the ground has been properly prepared, it will not be necessary to dig large holes. 12 to 18 inches square and about the same depth will be large

Tough for the average size apple tree. so that it can be used to fill in about the roots.

After a tree has been flaced in its exact position and about as deer as it stood in the nursery, the roots are spread out and
good top soil worked under and around

\section{Care of Transplanted Trees}

The first two years is the critical period. It is of vital importance to have them make a good start, for summer drought is likely to prove fatal to trees of low vigor and slow growth. So it is necessary to cultivate thoroughly and systematically to conserve the moisture and aerate the soil. The first summer the soil should be frequently stirred to make a soil mulch and prevent baking and crusting of the surface. The second summer the ground should first be plowed deep, as early in the spring as possible. Cultivation should be stopped about July 15 th to August 1st that the trees may have time to mature and harden in preparation for winter. them. Moving the tree slightly up and down will help to get the soil under the tramp the soil firmly. After this fill the hole to the top and again tramp the soil. Lastly throw a few shovelfuls of loose dirt about the tree to prevent loss of moisture.

If you have to plant when the ground poured around the roots water should be poured around the roots after they have filled. Ordinarily watering is the hole is sary and might do more harm than good. Don't rut manure or other fertilizer in the holes in contact with the roots; spread the holes in contact with the roots;
it on the ground around the tree.

\section{Pruning the Tops}

Even with a special tree-digger and particular care, part of the roots of trees dug in the nursery are cut off and the small feeding roots are lost anyway, so the tops have to be cut back to restore the balance. This is done either just before or after planting.

One year apple trees, without side branches, are cut off just above a sound

bud, 24 to 30 inches from the ground.

ike Jonathaties of one-year budded apple they.have been pruned in the nursery. but 3 to 5 side branches cut of have al close to the trunk. Select these branches on different sides of the trunk and spaced 6 to 8 inches apart. Leave also one branch growing from the top. Shorten this leader a little and cut back the selected side ranches $1 / 3$ to $1 / 2$ their length.

Pear trees are pruned like apple but usually headed lower, 12 to 15 inches rom the ground.

Dware Pears are usually trained to pyramid form, which calls for a centra trunk with side branches, the longest earest the ground.

Peach-The fruit is borne on last year's wood. After the tree is planted, cut off and cut off any side branches about an inch from the trunk, leaving one or two good buds.

Plums and Apricots are pruned like each trees.

One-year Sweet Cherry are usually whirs which are cut off just above a bua $2 \frac{1}{2}$ to $3 \mathrm{ft}$. from the ground.

Sour Cherry, even one-year, are almost always branched and the general practice is to cut off close to the trunk all but central leader unpruned. high.

quince are headed low, about 18 inches

\section{Common Causes of Failure to Grow}

1. Planting trees that were dug in the ursery before they became dormant.

2. Drying out from exposure to sun or drying winds, or freezing in the cold before setting out.

3 . Crowding the roots into small holes cut in the sod.

4. Failure to firm the soil closely about the roots.

5. Leaving the trees or plants uncultivated.

6. Leaving the tops unpruned.

7. Not planting at the proper depth.

8. Planting in soil too wet or too dry. 


\section{Buy Fruit Trees by Diameter or Thickness}

We grade our fruit trees by diameter, measuring the thickness of the trunks two inches above the ground. This insures better values to our customers. The reason is this: At planting time you have to cut off $1 / 3$ to $1 / 2$ the tops in order to restore the balance between tops and roots, because some of the roots are bound to be lost when the trees are dug in the nursery. Surely you are not concerned about the part you throw away, but rather about the part you have left.

Neosho Trees Graded by Diameter This is a bundle of 10 two-year Apple trees 11/16 in. up in diameter, 5 to $7 \mathrm{ft}$. tall. Note how uniform the trunks are, graded by the diameter about two inches above the ground. They are headed 28 to 30 inches high and have plenty of tops to cut off and throw away after you plant them. They are well-rooted, clean, healthy and in prime condition. Ten of them weigh about 20 pounds and have to go by
freight or express. There are none better at any price.

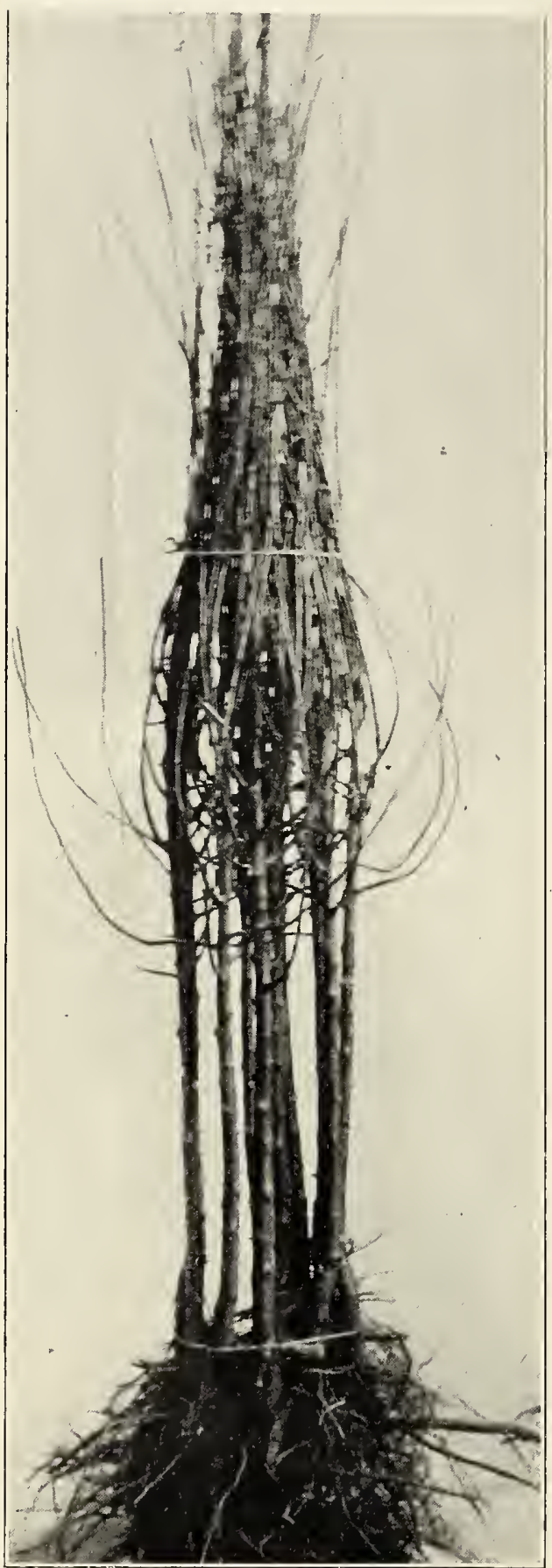

Suppose you prefer the largest size one-year apple ( $2 \mathrm{yr}$. root). We would send you trees whose trunks are $\frac{9}{16}$ of an inch thick and from 4 to $6 \mathrm{ft}$. tall. But if we graded by height only we could send you trees as small as a lead pencil, but just as tall as the $\frac{9}{16}$ in. You can see what a difference there would be by looking at the following illustration of sizes according to diameter.

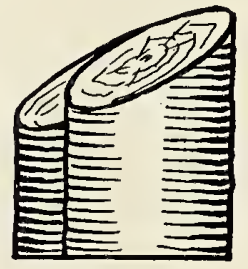

$11 / 16$ UP

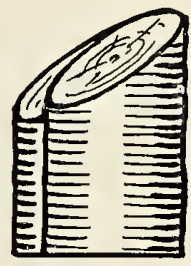

$9 / 16^{\text {TO } 11 / 16}$

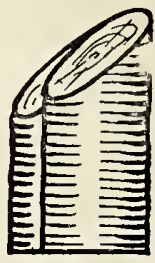

$7 / 16^{\text {TO } 9 / 16}$

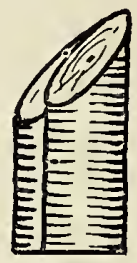

$5 / 16^{\mathrm{T} 0} 7 / 16$

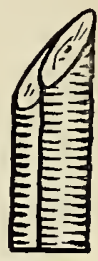

$3 / 16^{\text {T0 } 5 / 16}$

When nurserymen buy fruit trees from other nurserymen, they are graded by diameter. The buyer can tell in advance what he will receive only when he buys by diameter.

We took 100 of each size Jonathan apple trees (one-year top, two-year root) at random from our stock and regraded them by height. Out of the 400 trees, 306 were $4 \mathrm{ft}$. to $6 \mathrm{ft}$. tall, 73 were 3 to $4 \mathrm{ft}$., and 21 were 2 to $3 \mathrm{ft}$. These 400 trees graded by height would have cost you at the 100-rate, $\$ 105.27$, but the same trees graded by diameter according to our method would have cost you only $\$ 79.00$ - a saving of $\$ 26.27$.

Our trees are noted for their root systems and vitality. They are clean and healthy, free from injurious insects and disease, such as aphis, nematodes and crown gall. There are no better trees obtainable at any price.

\section{Plant This Attractive Novelty}

\section{Five-in-one Apple Trees}

We have a limited number of apple trees with from 3 to 5 different varieties budded or grafted on as many different branches.

These varieties ripen from early sum mer to late fall-Duchess, Wealthy, Grimes Golden, Jonathan and Delicious -all dependable high grade apples.

You ean inagine what a beautiful sight one of these trees will present in bearing.

The only pruning you will need to do is to cut back the side branches about one-half their length, and shorten any roots that are too long.

The top branch and trunk is the Delicious, the other branches are labeled.

These trees are 3 years old with trunks $11 / 16,3 / 4$ and 1 inch or more thick.

The white bands around branelies ir photograph at the right indiente where limbs should be eut of winen planted.

"l ain ohighly pleased with the trees I have purchased from you during the last two years, and find them superior to trees purchased from other companies."-Eden C. Booth, Missouri.

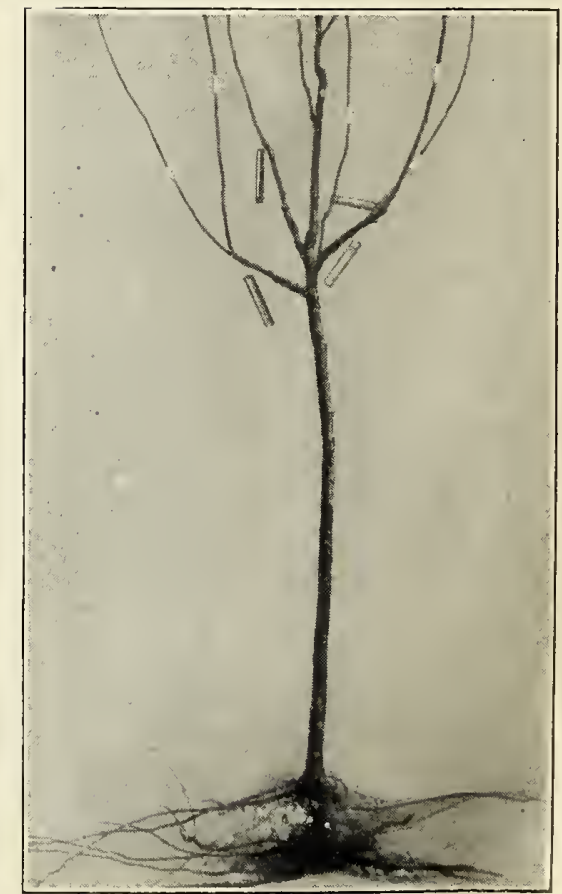




\section{Apples! King of Fruits!}

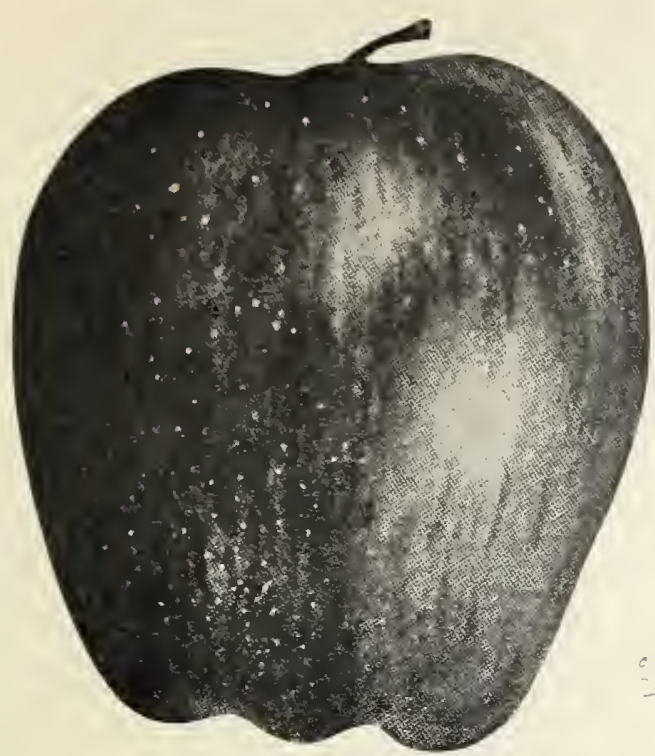

The Incomparable Delicious

“ACCLIMATED" NERSERY STOCI

Experience proves that it makes no difference where stock is grown provided it is first-class and the variet. is adapted. land and other foreign countries.

"I wish to state that all the trees I bought from you were perfectly satisfactory. This is more than I can say of two other concerns that purchased from at the same time, as your trees are all alive at this date, while many of the others Carter, Ilassachusetts.

"At this time I wish to express my thanks for the fine trees sent me last year. All started very well and I believe I will now have a $100 \%$ stand. I am glad to say that the trees you have sent me the past two years were the finest I have ever had from any nursery, and I have purchased well over 2,000

"I shall be glad to recommend your stock to others in the future, as I have in the past, and when I am again in the market will get in touch with you." -Wm. Rosin, Ohio.

\section{TRIPLE THE LIFE OF YOUR GRIMES TREES}

\section{by planting our double-worked trees. The Grimes part is} bydped about is inule-worked trees. The Grimes part is not susceptible to collar-rot. These Donble-worked Grimes have roots and stock that are two seasons growth. Prices are the same as for two-year apple.

\section{Plant Neosho Quality}

Every home garden and farm should have at least a few apple trees of summer, fall and winter varieties. They will give satisfaction far beyond the time, labor and money required.

This condensed table will help to choose an assortment that will give you afples the year round if you have a good cellar Most summer and fall varieties ripen over a period of several weeks and many are good for cooking before ripe. Winter varieties are picked when mature but before they are ripe enough to eat. Maturity can be told by the changing from a hard dead green color to warmer reds and wellows, by the seeds turning brown and by the readi rates from the twig.

Varieties marked are adapted only to northern climate: V-I-Very Large

Under "Quality," F-Fair; G-Good; V-G-Very Good; B-Best. Under "Use," Ć means for Cooking; D for Dessert.

Varieties

Color

Size

Quality

Keepe in

EARLY SUMMER:

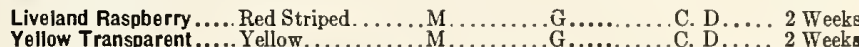
MIDSUMMER:

Red Astrachan ........ Red Striped . ........ . to L.....G. to V. G...C. D. ... 3 Weeks Duchess of Oldenburg.. Red Striped.................. to V. G...C...... 2 Weeks Wilson Red June ....... Deep Crimson......... to L..... V. G....... C.... 3 Weeks Sweet Bough.........Greenish-Yellow....M............ to V. G...C. D .... 2 Week LATE SUMMER:

Maid en Blush........ Yellow-Red Blush...M.......G.......... D....7 Weeks

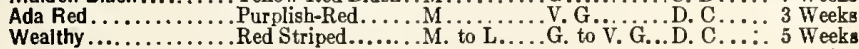
FALL:

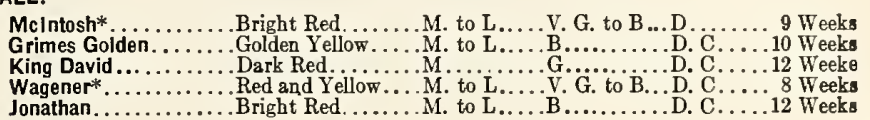
WINTER:

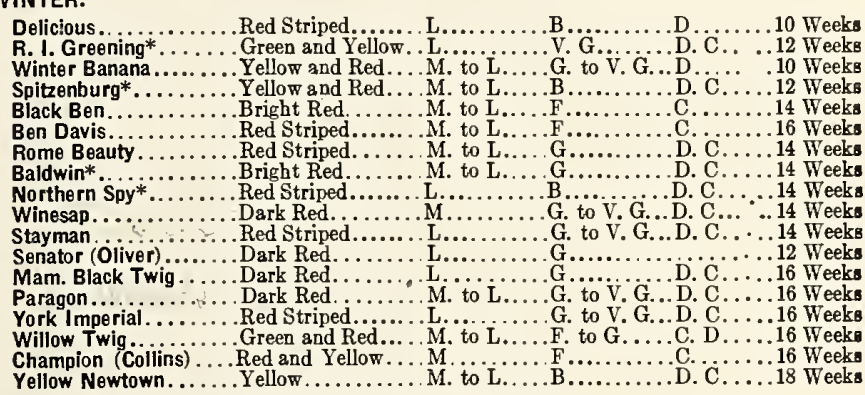

CRABAPPLES: These varieties ripen about two weeke apart.

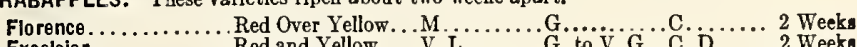

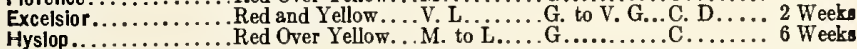

This 4 yr. old Black Ben is one of 500 of our trees planted by W. S. Cope.

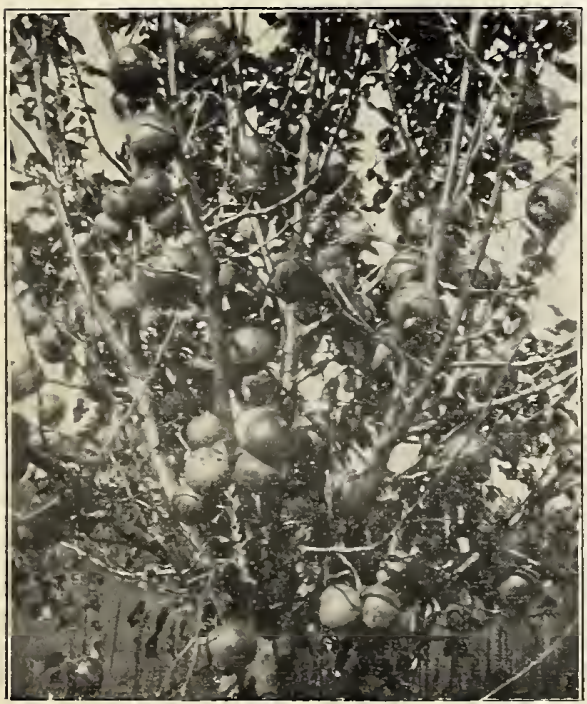

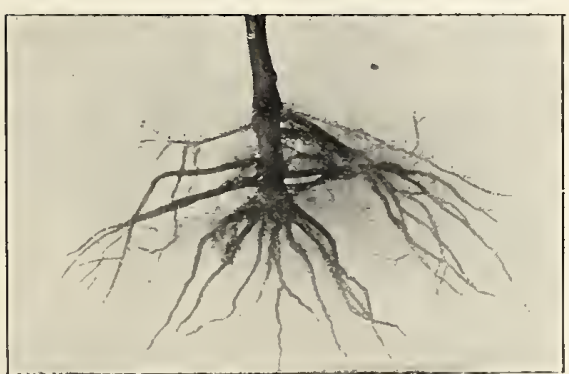

\section{Neosho Trees Have}

Superior Root Systems

We challenge comparison of our trees with those from any other source.

If you try our trees you will come back to us for any new plantings.

"I wish to express my thanks for the 1,000 apple trees I bought of you one year ago. They have made a fine growth. I like your way of doing business."-J. E. Anderson, loiva.
This Delicious apple tree is 4 years old and has about a hundred apples.

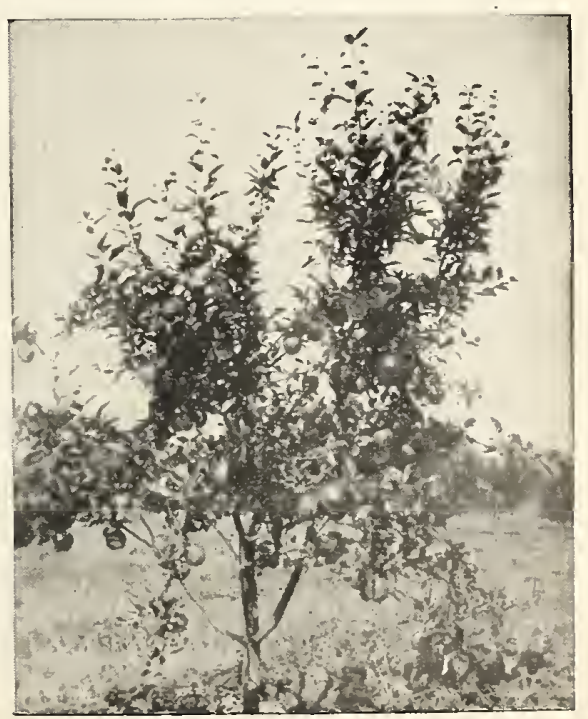




\section{"Your Trees Are Bearing Big Beautiful Crops"}

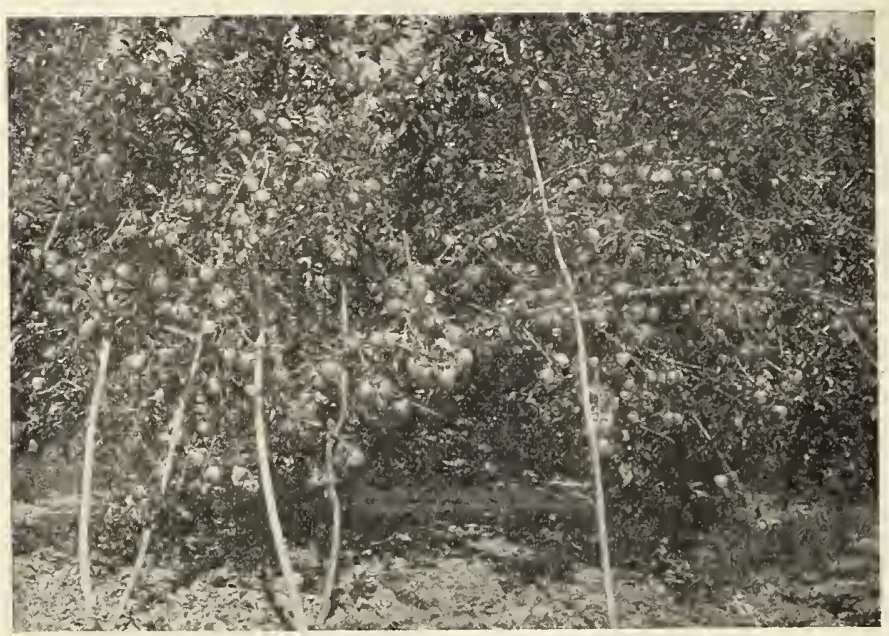

Delicious apple tree showing wonderful productiveness. Thls Washington orelard began hearing the third year and when nlne years old averaged five barrels per tree. They sold por B6.00 to $\$ 7.50$ per barrel.

ADA RED (Late Summer)-Originated in Northwest Arkansas where the only two orchards now in bearing are located and is harvested about August 15. It has not been tested in other districts to our knowledge. It is a particularly early bearer. The fruit is medium size, roundish; yellow, nearly covered with red and broken stripes of purplish crimson; flesh whitish; flavor mild subacid; quality good; good for dessert, excellent for cooking.

\section{ALBEMARLE PIPPIN-(See Yellow Newtown.)}

BALDWIN (Winter)-The Baldwin is the leading variety in the commercial orchards of New York, New England, and certain parts of Canada; also in Michigan and Northern Ohio. In the South and Southwest it is not desirable, because it ripens too early, and drops from the trees before its good qualities are developed. It does fairly well in the Pacific Northwest, but cannot be grown in competition with the Northeastern States. The tree is a strong grower, long-lived, and vigorous. It is somewhat slow in reaching maturity, but usually begins to bear abundantly about the seventh year. Fruit large to very large, uniform in size; form, roundish to conical; skin is tough and smooth, blushed and mottled with bright red; flesh yellow, firm, moderately coarse, crisp, tender, juicy, agreeably subacid, good quality.

BLACK BEN (Winter)-The best of the Ben Davis family. It attains a much higher color than the Ben Davis or Gano. The tree is hardier, more vigorous, and more prolific than the Ben Davis. Bears about the sixth year; fruit is large, solid dark red; flesh is white, firm, juicier than Ben Davis, mild subacid, fair quality. It is preeminently successful in Virginia, Kentucky, Tennessee, Illinois, Missouri, Arkansas, and portions of adjoining states.

CHAMPION (Collins Red) (Winter)-Tree hardy, very heavy, regular and early bearer. Fruit medium in size, roundish; attractive deep red striped with purplish carmine, but when not fully colored is yellow striped with red; picking season, Southwest Missouri, mid-October. Comparatively low quality but good for such a late keeper. Cold storage limit May or June. Sells well on Southern markets.
DELICIOUS (Winter)-Who is not familiar with this justly popular apple? Who does not appreciate its unexcelled flavor, its beauty of form and color, its fragrant aroma? It is mild in flavor, crisp and juicy, the best in quality. It is large in size and the five knobs at the blossom end are a distinctive characteristic. In color it varies with climate, soil and management; more or less striped with dark red, often a dark crimson. It finds a ready sale at high prices. The tree is vigorous, hardy and is fruiting in nearly every state.

DUCHESS OF OLDENBURG (Midsummer) - Attractive yellow apple, almost covered with red stripes; medium size. One of the most profitable summer varieties. The flesh is tender, juicy, subacid; very good for culinary purposes even before fully ripe. Tree is a moderate grower; can be planted close and is often used as a filler. Comes into bearing young, often fourth year. Bears heavy crops annually; great market apple and especially good cooker. Ripens in succession, requiring several pickings. Extremely hardy.

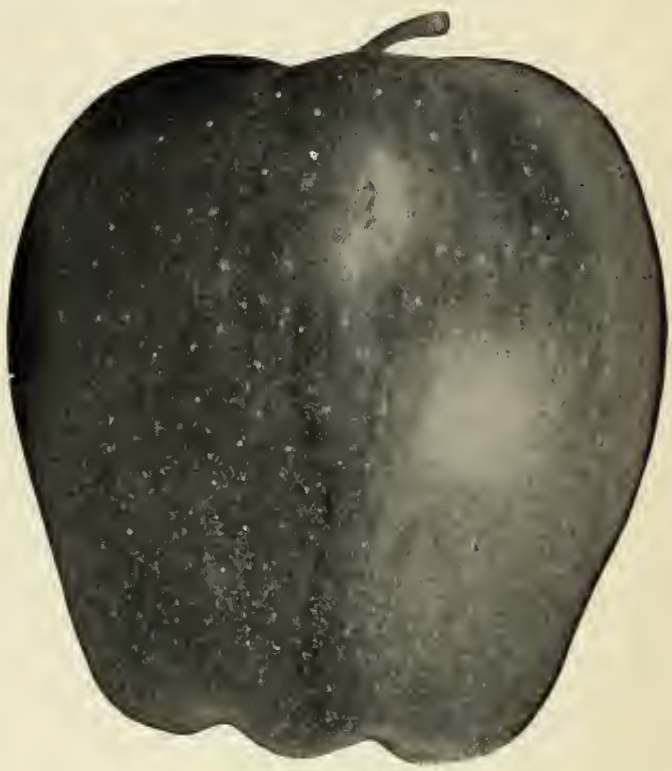

The Incomparable Delicious

EARLY HARVEST (Midsummer)-A pale yellow, medium sized apple of very good quality for either dessert or cooking. The tree is a fairly good grower, medium sized and comes into bearing young. Widely grown for home use.

GRIMES GOLDEN (Fall)-The standard of excellence, the best quality, profitable yellow apple; rich golden color, often showing a pinkish blush. Flesh is yellow, very firm, crisp but tender, rich, aromatic and juicy; very good to best quality; medium to large; an ideal dessert apple and a splendid cooker. Tree is a hardy, vigorous, upright, spreading grower and heavy regular cropper. Bears about the fourth year. The highest quality yellow apple and one of the best for home use and commercial planting. It is a leading commercial variety in Missouri, Arkansas and is successfully grown in many other middle latitude states. Plant double-worked trees only. 


\section{For Profit, Plant Varieties Known to Succeed}

\section{Science Wins!}

Practically the only fault of Grimes Golden, "Collar-rot" is now eliminated by planting o $\mathrm{ur}$ d o u b l e-worked trees.

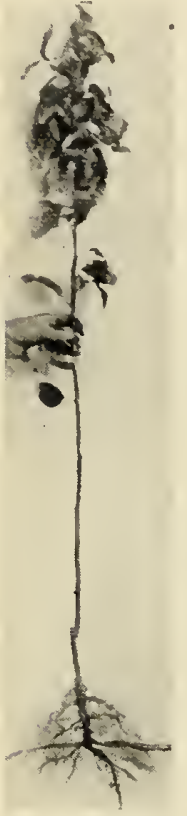

A

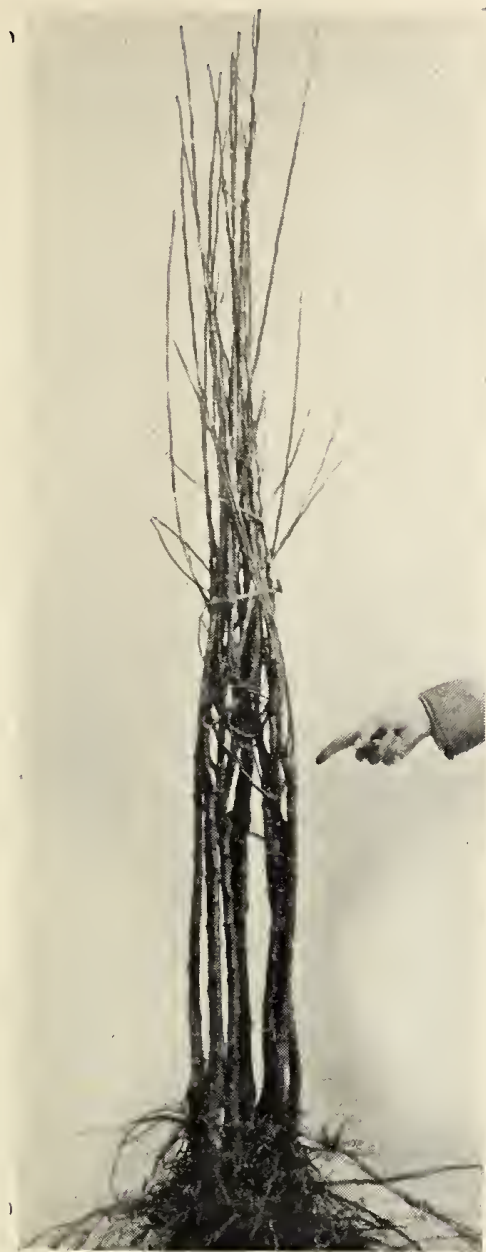

\section{TRIPLE THE LIFE OF YOUR GRIMES}

There are orchards of this variety 15 years old which are dying out on account of collar-rot which attacks the tree near the ground. They will live and retain their usefulness three times as long if the Grimes part is grown on a vigorous variety which is not subject to collar-rot.

In the spring we plant a graft of a hardy variety. Then in midsummer we insert the Grimes bud in the trunk 18 inches from the ground. (See Fig. A above.) This bud doesn't grow until the following spring when the top is cut off just above the bud. The tree is ready to dig in the fall. The roots and the lower part of the trunk are then two years old. The Grimes part is one year old. (See Fig. B.) Some are whips and some are well branched.
JONATHAN (Fall)-A grand, good apple; once tasted, always wanted. Bright solid red, deep red on the sunny side. Flesh whitish, sometimes tinged with red. Firm, fine, very crisp and tender. It has an aromatic flavor and juice which is full of snap and sparkle. Medium size; very good to best quality. Tree is moderately vigorous, long-lived, an upright grower. Bears about fourth year. Produces good crops regularly. Fine for home and commercial planting.

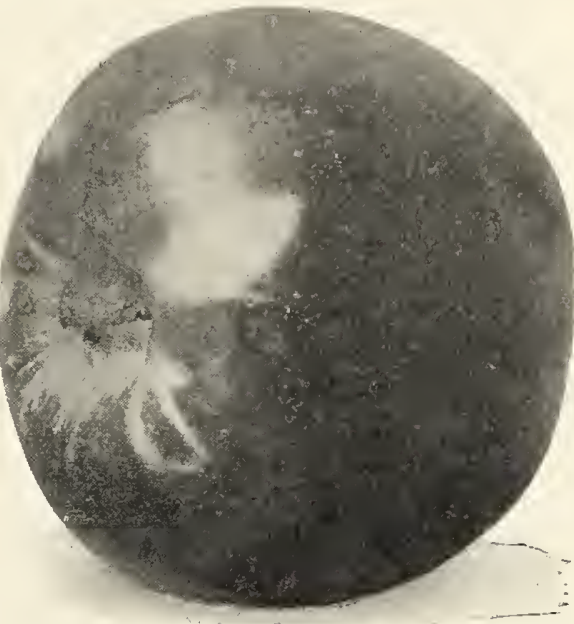

The Beautiful Red Jonathan

The Best Quality Commercial Apple of Its Season.

KING DAVID (Fall)-Enormously productive, bearing heavy crops year after year. Uniform shape, tapering toward the blossom end. Medium size; very dark rich garnet red, showing almost a purplish-black on the sunny side. Similar to Jonathan but more tart. Tree is a hardy, vigorous grower, comes into bearing about the fourth year. Sometimes used as a filler.

LIVLAND RASPBERRY (Early Summer)-Beautiful red and yellow apple. Medium size; flesh is snow-white, tender, fine-grained, crisp and juicy. Very good. Tree is a strong, vigorous grower. Bears fourth to sixth year.

MAMMOTH BLACK TWIG-(The correct name is Arkansas. Often confused with Paragon.) A large apple of good. quality; a dull green or deep yellow overspread with red; good quality; excellent keeper. Formerly quite extensively planted in middle South and Southwest, bur not at present, because it is often a shy bearer. The tree is one of the best, making a fine, vigorous, spreading growth.

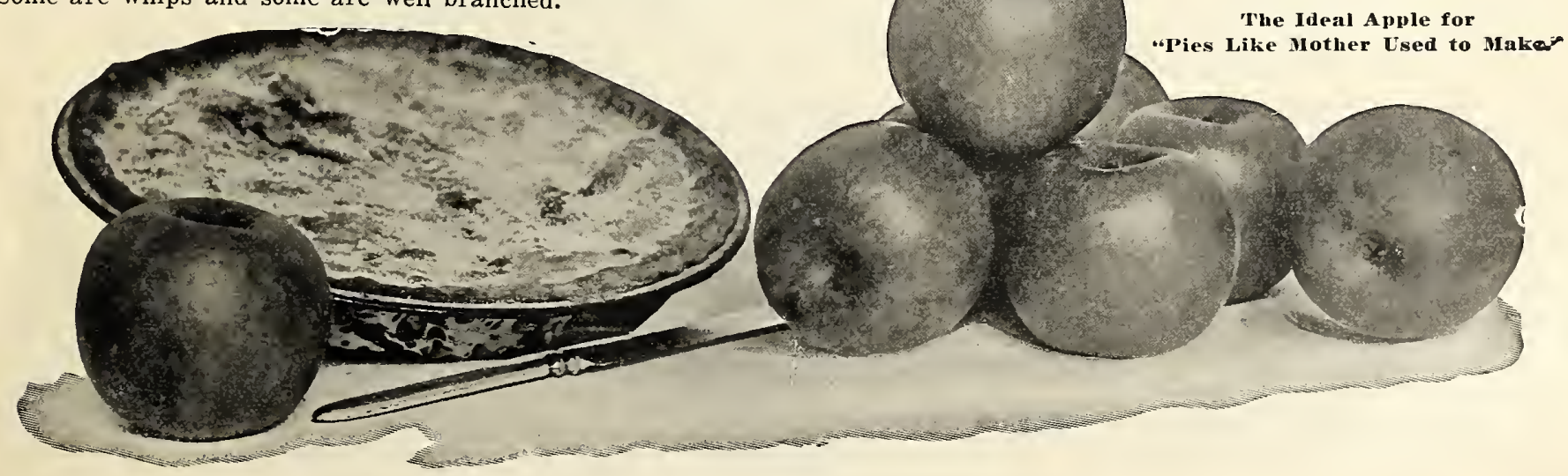




\section{'Your Trees Have Done Better Than Any Others'}

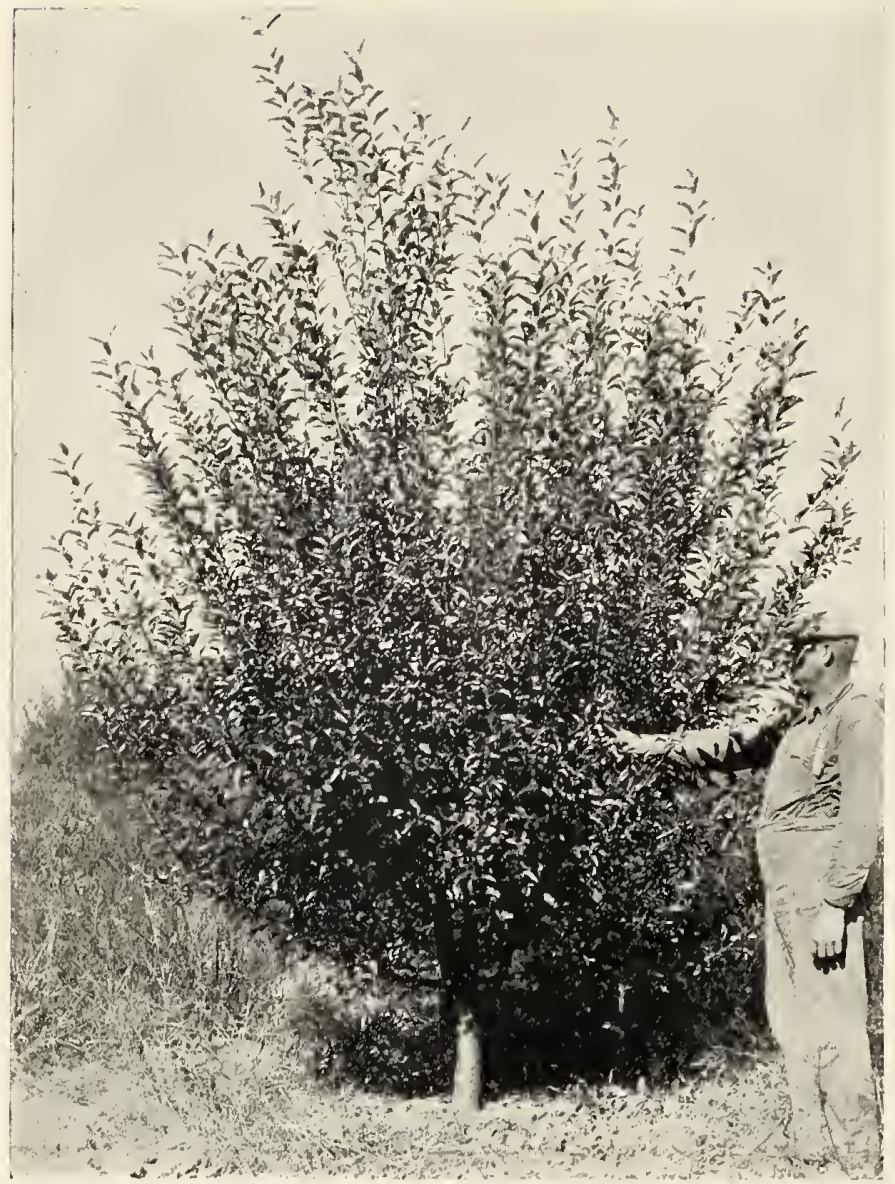

This picture, taken October 23, 1024, shows one of a thousand one-year Neosho Nurseries Apple Trees planted in the spring about 6 pt. $4 \mathrm{~m}$. tall. No wonder he is proud of his orehard.

PARAGON WINESAP (Winter)-Paragon has the large size and very good quality of the Stayman combined with the dark red color of the old Winesap. The true Paragon was introduced and named by Dr. W. L. Moores of Lincoln County, Tennessee, and has been largely planted under name of Mammoth Black Twig, giving the latter an undeserved reputation. Tree is equal in every respect to Winesap; a more vigorous, open grower. Bears sixth to seventh year, and thrives wherever Wine. sap can be grown.

RED ASTRACHAN (Midsummer) - A general-purpose apple for home use and local market. Nearly covered with light and dark red stripes, overspread with bloom like a plum; large, roundish; white flesh tinged with red; flavor aromatic, brisk, subacid; very good. Good for eating fresh out of hand when fully ripe; an ideal cooker. Tree is hardy, of the Russian type, moderately vigorous, upright, spreading; adapted to every state where apples grow. Bears fourth year.
MAIDEN BLUSH (Late Summer)-Striking, highly colored, yellow apple, with a deep crimson blush on one cheek. Round, flat, medium size; flesh white, crisp, tender, very juicy; a good eating and excellent cooking apple. Tree is vigorous, spreading, and open. Usually bears fourth to fifth year.

McINTOSH (Fall)-One of the best early winter apples for northeastern states; noted for its high quality and delightful fragrance. Medium to large size, roundish, slightly flattened at the stem end. Beautiful deep crimson, striped with carmine and overspread with a heavy blue bloom. Crisp, snow-white flesh; is very tender and juicy, entirely different from "meaty" apples like Spitzenburg and York. Makes a strong appeal to people who pay high prices for fancy fruit. Tree is longlived, a strong, vigorous grower, with an open, spreading head, and very hardy. Bears fourth to fifth year. One of the best apples of its season, both for home planting and to supply not-too-distant markets.

MINKLER (Winter)-A light red attractive apple of good size and fairly good quality, mild subacid. Keeps exceptionally well in common storage. Widely distributed in the Ozarks of Missouri and Arkansas, but not planted extensively. The tree grows large and very vigorous, a regular but light producer.

NORTHERN SPY (Winter)-Attractive, red-striped winter apple; large, roundish and plump, tapering slightly toward the blossom end. Flesh is firm, fine-grained, crisp, rich, subacid, very fine quality. It appeals to those who like a brisk, spicy apple that is not actually sour. Tree is a vigorous and unusually healthy grower. Bears seventh to twelfth year. An old-time favorite in the North and Northwest.

RHODE ISLAND GREENING (Winter)-A large, roundish, green winter apple, yellow when fully ripe. Tender and full of sparkling juice, with rich flavor surpassed by few apples. One of the best dessert apples and an excellent cooker. Tree is a large, vigorous grower, with wide spreading branches, drooping and dense, usually late in coming into bearing. A North and Northeastern variety.

ROME BEAUTY (Winter)-Large, roundish, oblong apple, handsomely colored and striped with bright red; one of the most beautiful and profitable late winter apples. Flesh is firm, crisp, juicy and of good quality. Splendid storage apple. Tree is a vigorous, upright spreading grower; hardy, except along the Canadian border. Very profitable in the central United States, Rocky Mountain country, and some Southern states; a splendid bearer, blooms late. Bears fourth to fifth year.
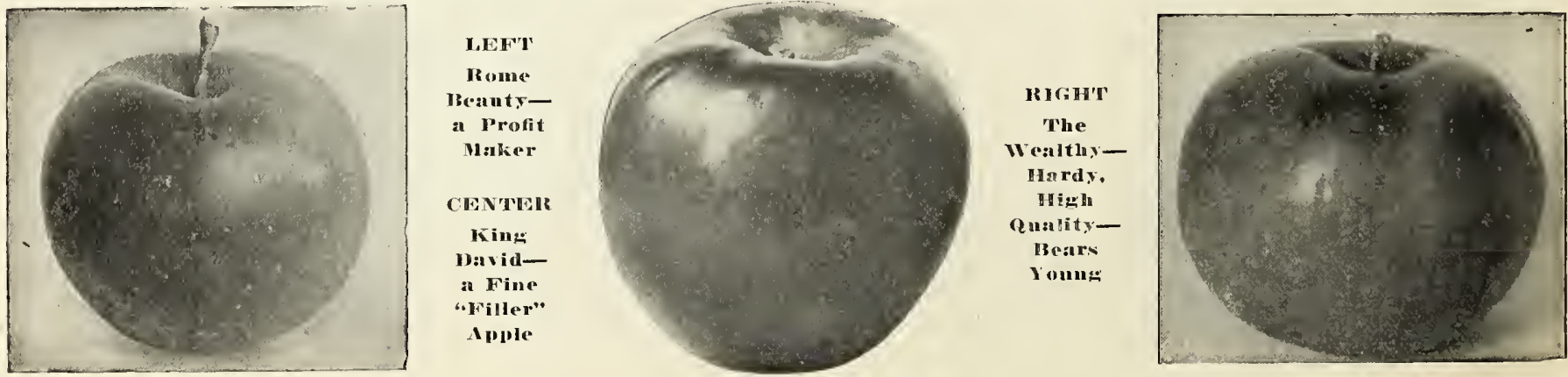


\section{Every Neosho Apple Is a Tried and Proven Variety}

SENATOR (Oliver-Red) (Winter)-A medium to large, attractive, roundish apple of good to very good dessert quality. Under color yellow, washed over nearly entire surface with bright red and with numerous gray or russet dots. A fall apple in the Ozarks of Missouri usually picked early in September.

SPITZENBURG-(Esopus Spitzenburg) (Winter)-Large, handsomely colored, bright purplish-red, shaded with yellow and striped with darker red; flesh firm, tinged with yellow; moderately juicy, spicy, very best quality. Tree is moderately vigorous, spreading; a rather moderate cropper. Thrives in favored Northern localities, particularly in the Northwest. Should be planted in deep, fertile, well-drained soil. Bears about the seventb year.

STAYMAN WINESAP (Winter)-The largest of the Winesap family. Striped and splashed with dark crimson, resembling Winesap, except that the color is not quite so brilliant; flesh tinged with yellow, firm, crisp, sprightly pleasant, with a rich subacidity that appeals to everyone. Splendid quality. Tree has a dark, heavy foliage, closely resembling its parent, the Winesap; thrives on thin dry soil where Winesap would fail. Reliable annual cropper; bears the fourth to fifth year. It does best in middle latitudes.

SWEET BOUGH (Midsummer)-A sweet apple, juicy, good to very good for dessert, excellent for cooking. Begins to ripen about the first week in July. Color is a greenish yellow changing to yellowish white.

WAGENER (Fall)-Bright red apple, strongly contrasting yellow background color; medium to large; whitish flesh, tinged light yellow, firm, fine-grained, juicy, very good quality. Tree is straight, vigorous, upright grower; enormously productive, usually bears third to fourth year. Often used as a filler. A Northern variety.

WEALTHY (Late Summer)-A most dependable and widely planted late summer apple; bright red striped; medium to large size; white crisp flesh tinged with red; good for cooking before it ripens. Ripens over a long season. Very good quality. Tree is an upright grower; often used as a filler; very hardy; bears fourth or fifth year. Adapted to many soils and climates, but especially suited for Northern planting where extreme hardiness is required. Good shipper; especially recommended for home use and commercial planting.

WILLOW TWIG (Winter)-Medium to large yellowish green, washed and striped with dull red; flesh yellowish, mild subacid; good quality; a good, long keeper. Tree strong grower, spreading, with drooping willowy branches. Rather early and regular bearer. A semiSouthern variety.

\section{"I NEVER HAD BETTER TREES"}

October 23. 1924.

"The trees I bought of sou to plant the 40-acre orehard were fine and $I$ never had trees that made a better growth. I con-

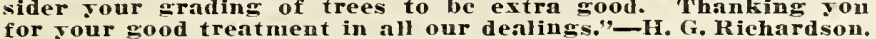

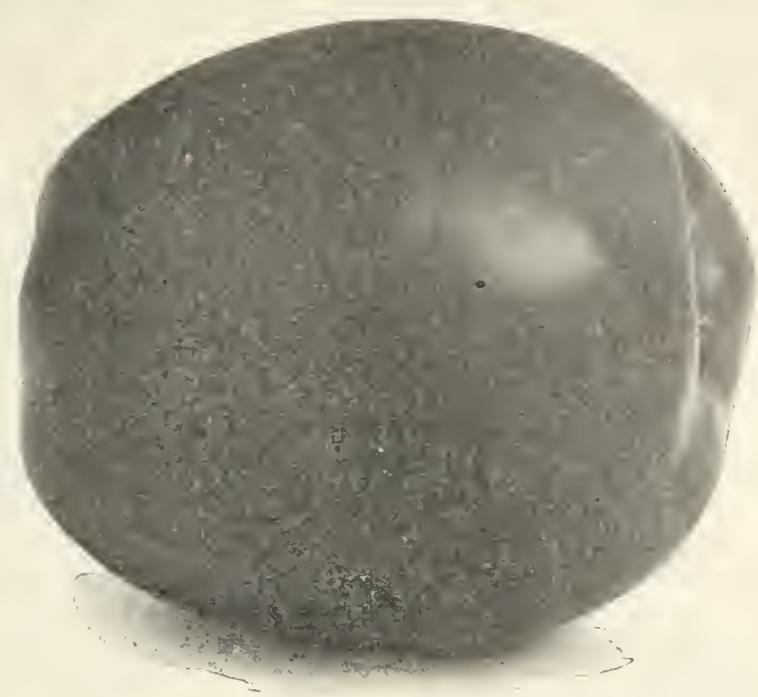

The Big Crimson Wilson June

The Most Beantiful of its Season, Good Shipper.

WILSON JUNE (Midsummer)-A deep, solid crimson, like a Red June; large; firm white flesh; good quality. Tree makes a moderately strong growth, is hardy, vigorous, very productive, bears young. Most beautiful of its season; good shipper.

WINESAP (Winter)-One of the oldest and most popular apples, a good shipper and an exceptionally good keeper in ordinary and cold storage. Well-grown Winesaps command a premium over most other winter apples with commercial buyers. Splendid bright red, indistinctly striped with dark purplish-red. Flesh is tinged with yellow; very firm, juicy, very good quality. Medium size; a favorite with everyone. Tree is a vigorous, spreading, open grower. Hardy, adapted to planting in every part of the country, except in the extreme Northern states. Will succeed on many different kinds of soils, preferring a deep loam. It is a heavy, regular bearer. Produces the first crop about the fifth year.

WINTER BANANA (Winter)-Very showy, bright yellow, with a pinkish-red cheek; noted for its brilliant, transparent, waxen appearance; medium size; good quality, with a rich, spicy flavor. Tree is a good average grower, adapted to many conditions; flat, spreading top; hardy, except in extreme North; regular cropper; bears about the fifth year.

This picture, taken october $\mathbf{2 3 ,} \mathbf{1 9 2 4}$, is the 10 -acre orehard of $\mathbf{H}$. G. Richnrdson, whose letter is quoted above. These trees werc

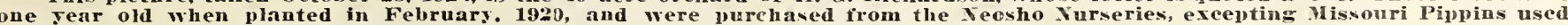
as fillers.

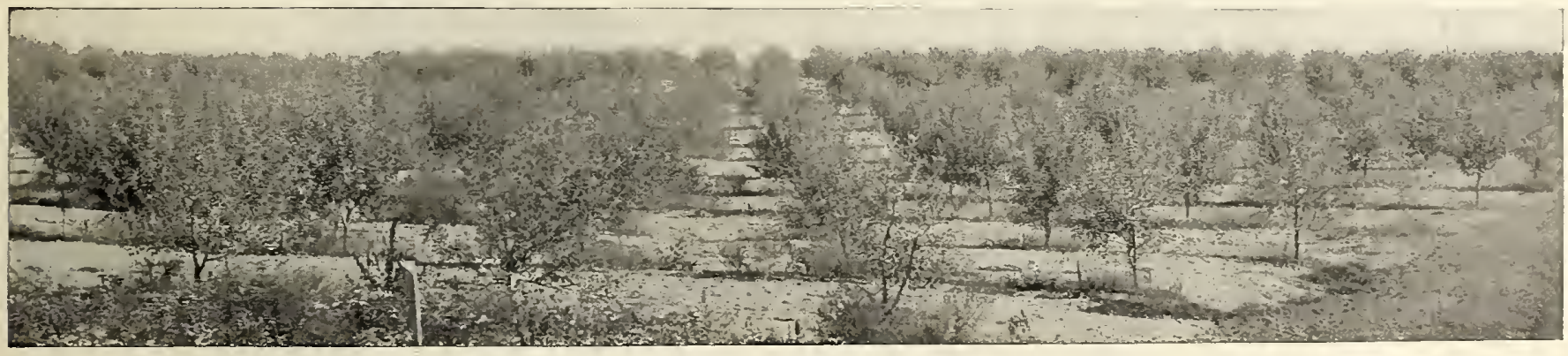




\section{"Your Trees Are Bearing All True-to-Name"}
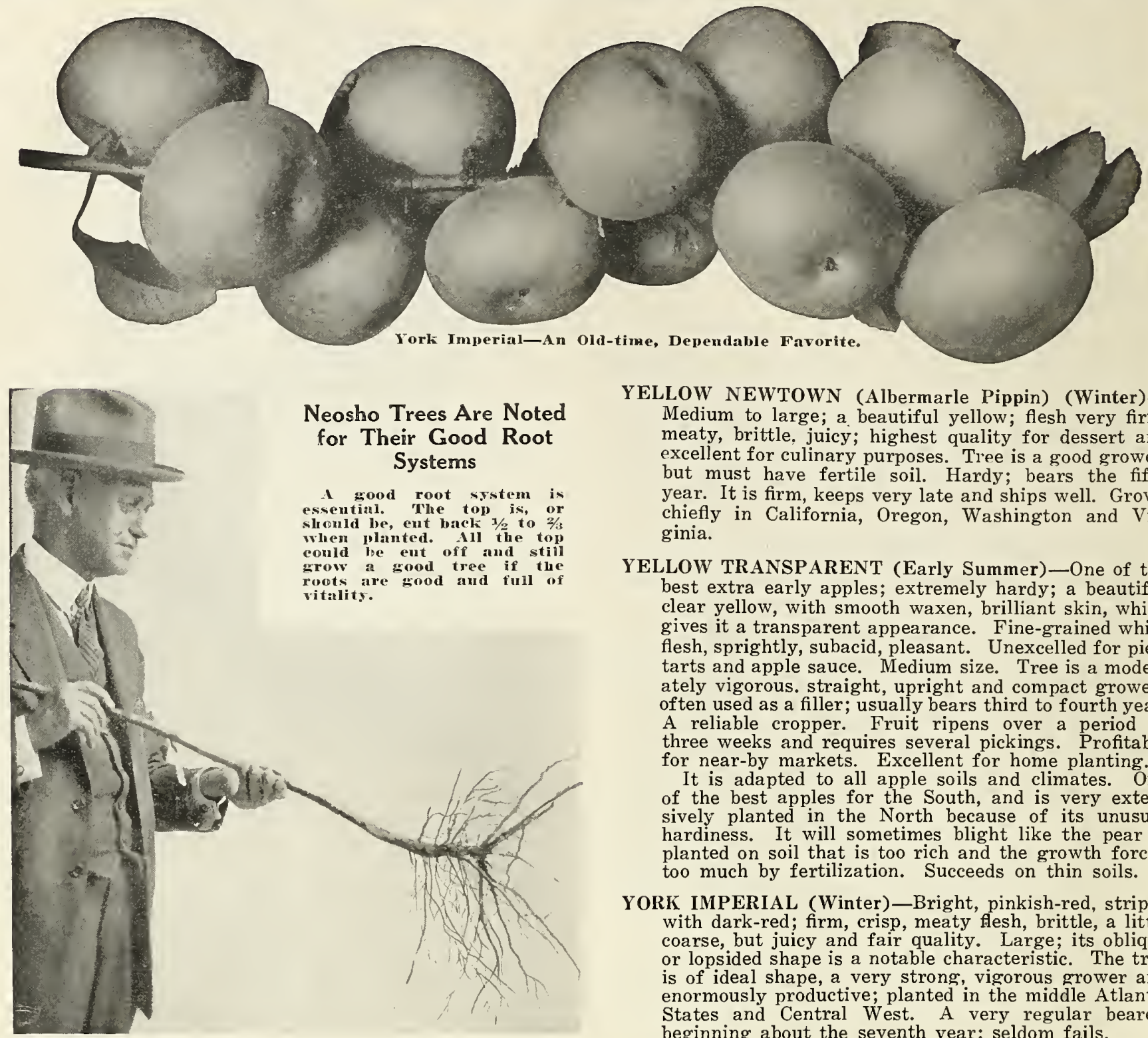

YELLOW NEWTOWN (Albermarle Pippin) (Winter)Medium to large; a beautiful yellow; flesh very firm, meaty, brittle, juicy; highest quality for dessert and excellent for culinary purposes. Tree is a good grower, but must have fertile soil. Hardy; bears the fifth year. It is firm, keeps very late and ships well. Grown chiefly in California, Oregon, Washington and Virginia.

YELLOW TRANSPARENT (Early Summer)-One of the best extra early apples; extremely hardy; a beautiful clear yellow, with smooth waxen, brilliant skin, which gives it a transparent appearance. Fine-grained white flesh, sprightly, subacid, pleasant. Unexcelled for pies, tarts and apple sauce. Medium size. Tree is a moderately vigorous. straight, upright and compact grower; often used as a filler; usually bears third to fourth year. A reliable cropper. Fruit ripens over a period of three weeks and requires several pickings. Profitable for near-by markets. Excellent for home planting.

It is adapted to all apple soils and climates. One of the best apples for the South, and is very extensively planted in the North because of its unusual hardiness. It will sometimes blight like the pear if planted on soil that is too rich and the growth forced too much by fertilization. Succeeds on thin soils.

YORK IMPERIAL (Winter)—Bright, pinkish-red, striped with dark-red; firm, crisp, meaty flesh, brittle, a little coarse, but juicy and fair quality. Large; its oblique or lopsided shape is a notable characteristic. The tree is of ideal shape, a very strong, vigorous grower and enormously productive; planted in the middle Atlantic States and Central West. A very regular bearer, beginning about the seventh year; seldom fails.

\section{Crabapples-Every Home Should Have One}

CRABAPPLES should be planted for beauty of tree and fruit, as windbreaks, and for the value of the fruit. They are delicious for cooking, preserving and jellies. Excelsior is delicious for eating fresh.

EXCELSIOR (Fall)-Very large for a crabapple, nearly as large as a medium sized apple. Very attractive yellow almost covered with bright red. Flesh is white, juicy, subacid, excellent in quality for dessert and for culinary uses. Tree is good, strong grower; hardy, healthy; comes into bearing rather young, and bears good crops alternate years.

FLORENCE (Late Summer)-Medium size, yellowish-white, mostly overspread with brilliant pinkish red. Flesh tinged with yellow, juicy, quite subacid, somewhat astringent. Tree is moderately vigorous; at first upright spreading but eventually inclined to droop. Bears very young, is very productive, reliable cropper and the fruit is of good size, very attractive and good quality.

HYSLOP (Early Winter)-Large, very brilliantly colored, dark red or purplish, overspread with thick blue bloom. Tree is a good grower, very hardy, reliable bearer, usually biennially. Flesh yellow, subacid, astringent; good for culinary purposes.

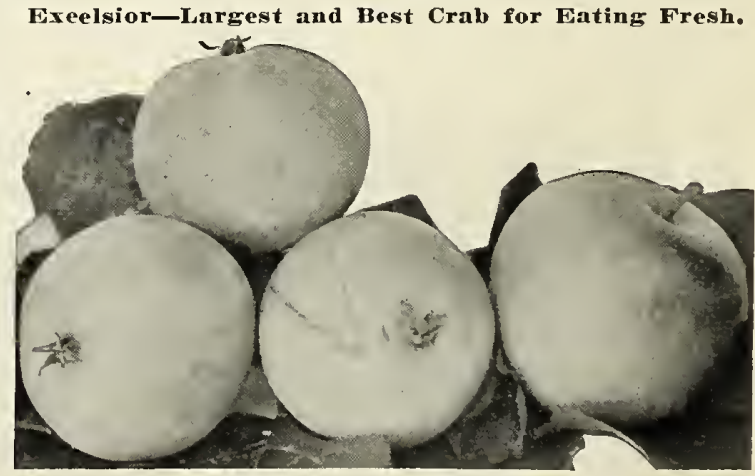




\section{Cherries-Home Grown Are Best}

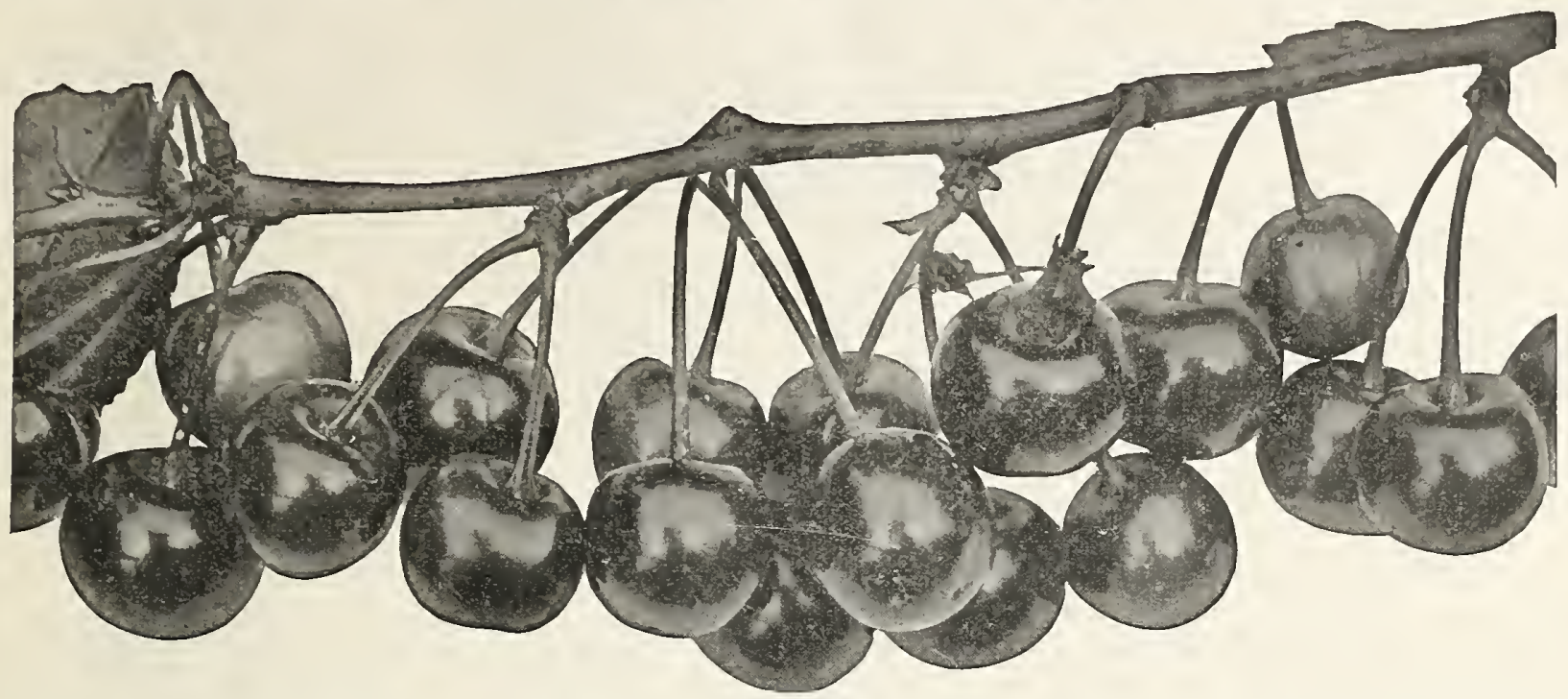

YOU may buy cherries fresh or canned; but if you ever tasted any fresh and ripe from the tree, you I will surely want a few trees of your own. Possibly you cannot grow sweet cherries, since they thrive only in favored localities, preferring a sunny, equable climate and a deep, dry, gravelly or sandy loam; they also require particular attention and care, especially in spraying. But the sour cherry can be grown almost anywhere. It is notably hardy and quite adaptable to different soils and climates, preferring a moderately heavy loam. The soil must be well drained. It does better under neglect than any other tree fruit. The three leaders-Early Richmond, Montmorenev and English Morello-ripen over a season of nearly forty-five days.

The sour cherry makes a fine ornamental windbreak, gives great satisfaction in the home garden and offers great possibilities for profit for the grower who supplies local markets.

\section{Sour Cherries--Dependable Varieties}

EARLY RICHMOND (Sour)-The favorite early sour cherry, and next to the Montmorency the most popular of all cherries. Fruit is medium size, roundish shape, flattened at the end; flesh light color, tender, and sprightly. A good canner, but not so firm as Montmorency. Tree is medium size, vigorous, upright, spreading, productive and long-lived. Ripens about a week earlier than Montmorency.

MONTMORENCY (Sour)-The most widely and most numerously planted cherry. It is the most productive and regular bearer. Colors early before ripe-a distinct advantage for shipping. The fruit is roundish, plump, flattened at the end, and a beautiful glowing red. It hangs in clusters, making picking easy.

The fruit does not crack or rot even in very hot, rainy weather. It hangs on without dropping after it is dead ripe. The flesh is rich, sprightly, and pleasant; flesh is reddish color, tender, and melting, but firm. A good ship. per and a good canner. Does not mash down in the box.

The tree is the largest, most vigorous grower of all the sour cherries. Round, spreading, upright head, especially hardy and productive; a very reliable cropper. Bloom is hardy and seldom injured by late frost or severe winter freezes. The Montmorency can be grown in practically every part of the country except the low lands of the extreme South. Adapted to great variety of soil and climate and succeeds well under adverse conditions. Ripens in Southwest Missouri first week in June.

ENGLISH MORELLO (Sour)-Fruit is small, dark red colored, very sour, but loses much of its sourness if left on the tree until fully ripe. First-class for canning and preserving. Stands lower temperature and severer drouth than any of the other leading varieties. Tree is small, round-headed with drooping branches. Bears young. Very productive and hardy but not as healthy nor adapted to many different kinds of soil as Montmorency or Early Richmond. Especially good for gardens where a small-growing tree is desired.

\section{Sweet Cherries}

A sweet cherry planted alone is not likely to bear fruit because it is self-sterile. Plant a Black Tartarian with any other sweet cherry.

BING (Sweet)—Very dark red, almost black; very large; very good quality; ripening midseason; blooms early.

BLACK TARTARIAN (Sweet)-Most widely planted sweet cherry east of the Mississippi. Beautiful, lustrous, purplish-black when ripe. Medium size for sweet cherry. Flesh purplish-red, firm, tender, pleasant flavor, sweet and mild; very good quality. The tree is a very large, vigorous, upright grower; adapts itself to widely different soils and climates. Very productive and regular bearer. Comparatively free from brown rot. Early.

GOV. WOOD (Sweet)-Yellowish-white tinted with crimson; large; very good quality; ripening early, with Black Tartarian; blooms early.

NAPOLEON (Sweet)-The best yellow cherry. Often sold and grown as Royal Ann. Best of the sweets for dessert and canning. Very particular as to soil and climate. Apt to crack in wet weather, and somewhat susceptible to brown rot. Nevertheless, it deserves first place among sweet cherries for home and commercial planting. It is an attractive yellow, with a bright red cheek; very large; long, heart-shaped; firm flesh. Meaty, crisp, mild and sweet; high quality. Tree is a hardy, vigorous, upright grower, with strong, sturdy limbs. Very productive and bears young.

WINDSOR (Sweet)-Dark red, almost black; large; good to very good quality, ripening late; blooms early; very hardy; upright grower.

BEST IN 10 XEARS

"I have been buying trees the past ten years and this lot is the best one-sear trees $I$ ever saw. I have 70 acres in trees:" -Irwin Paul, Michigan. 


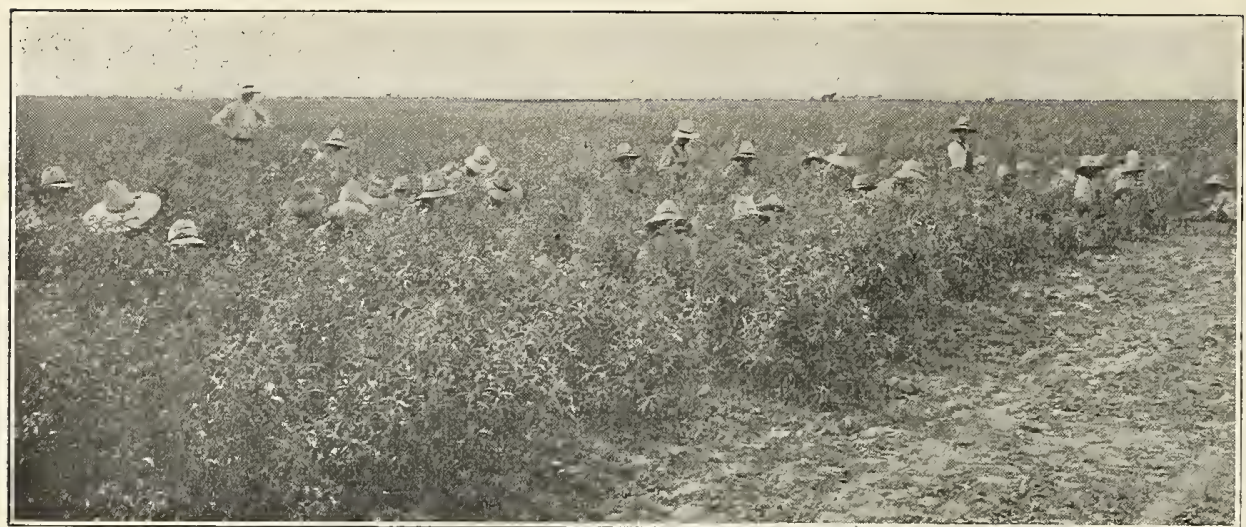

\section{Almost a Million Peach Trees}

(A) This picture was taken July 10th. Our records show that 844,412 of these seedling peach trees were budded that summer. The two pictures below are of the same field a year later.

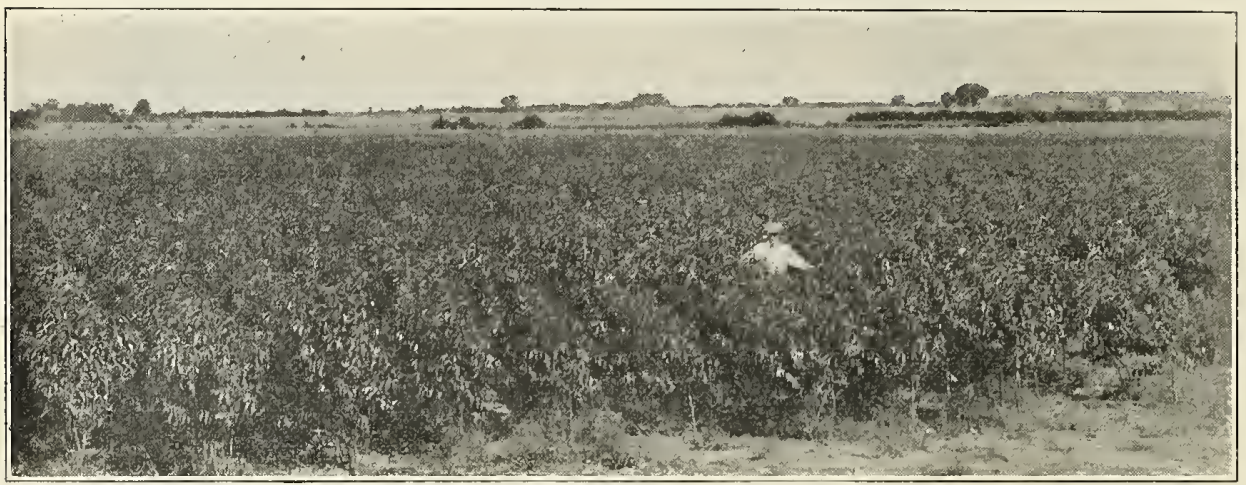

\section{A Wonderful Block of Trees}

(B) This is the same field as shown above in picture (A) taken September 1st. It contains peach, plum and apricot-one-year top, two-year root.

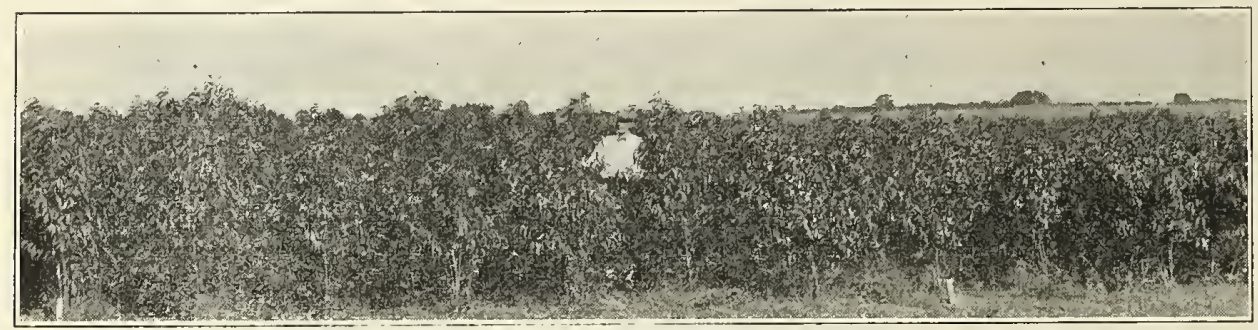

\section{Look at These Handsome Trees}

(C) This is another view of the same field shown in pictures (A) and (B). Yes, they are beautiful trees. Of course you cannot see a most important part, the root, but Neosho Nurseries trees are justly noted for splendid root systems.

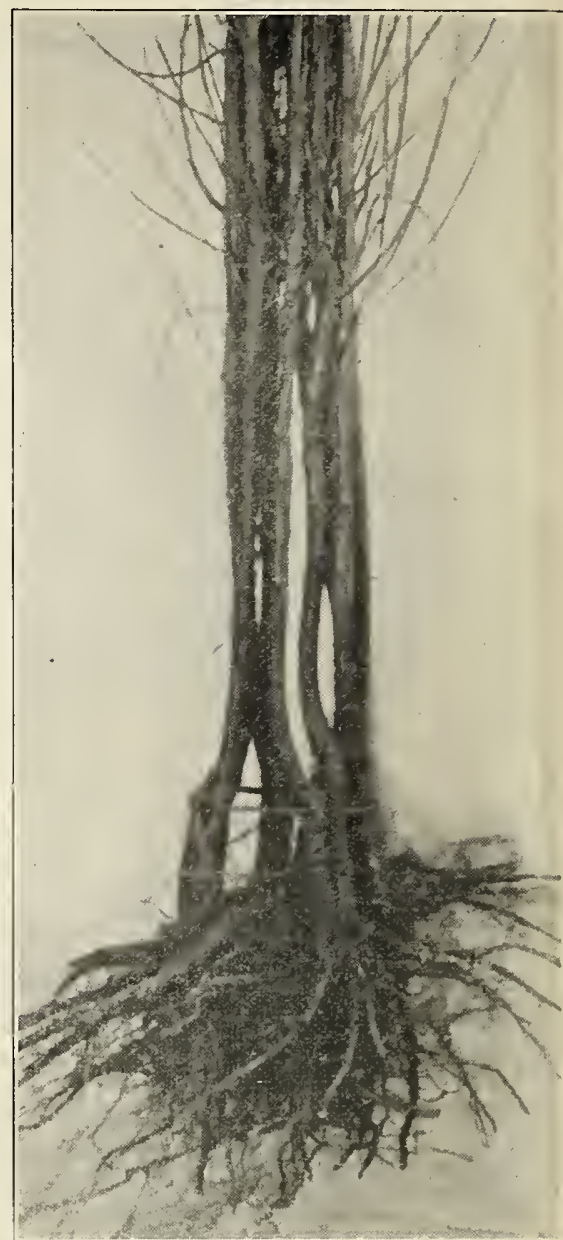

\section{How Do They Look?}

This shows 10 Elberta peach trees. Note the splendid root systems and sturdy trunks. Only two feet of the tops are shown; you would have no use for the parts that are cut off, anyway.

145 PER CENT PIROAIT!

"On the 11th we ordered 250 trees from you. You shipped them on the 12th and ve received them on the $13 t h$. We have never had quite such good service beforc much.

"You will probably be interested to know that our orchard planted in 1920 from sour trees has made four bumper and paid more dividends than any orchard ever grown in this part of the country. it has paid the stockholders their mones back that was put into it to start with and $45 \%$ besides and the orchard is now worth $\$ 100,000.00$. This might be good advertising for your trees."-Apri] 16. 1927. Big Four orchard Company, Hovard Count, Arkansas.

\section{A Yard of J. H. Hale Peaches}

Mr. Steves of San Antonio, Texas, sent ns this picture of fruit grown from Neosho Nurseries trees and wrote us: "These peaches are not the largest-one $I$ had weighed 16 oumees and it was solid and the finest flavor of any peach 1 lave ever eaten. According to my ilea it is the finest peach that has ever been grown in this section."

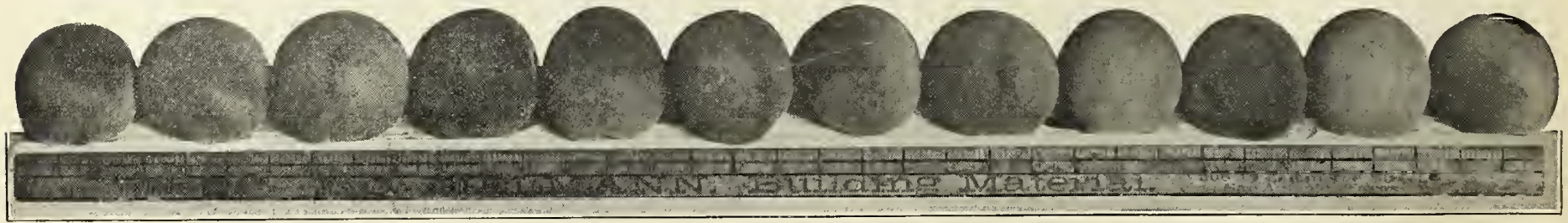




\section{"Growing Satisfaction" Brings More Orders}

You may have the finest orchard in the world and loaded with fruit, yet in order to enjoy a profitable sale from year to year you exercise great care to put up a quality pack.

So it is in the nursery business. We have good soil, a favorable climate and exceptional facilities for hauling, storing and shipping. We also have an organization skilled in producing, grading and handling nursery products. But most important of all is the fact that every move is actuated by the desire to live up to our motto, "Yours for Growing Satisfaction."

This is a sound policy which has proved profitable in many lines of business and the results in our own experience are indeed gratifying. Read the following extracts from letters in our files:

From Tennessee.

"If I am not mistaken this makes fifteen thousand trees I have bought of you in the last 7 years. Our dealings have been so satisfactory that it has been a pleasure to me to mention the Neosho Nurseries t my friends."-Mr. E. T. Russell

From Thode Island.

"The peach trees arrived in very good condition. I was much pleased contributes to the fact that you have established a real true business pol-

From New Jerser. three to 500 fruit trees from you and all are now bearing the finest fruit in the world. I have 150 to 200 Hale peach, that gave me fruit crop last year 100 per cent, full size beautiful fruit which I sold at $\$ 4.00$ per bushel."-J. C. Rudesill.

From North Carolina.

"I have been very much pleased the apple trees I got two years ago and last spring have done extra $\pi^{*} e l l$. this spring all are doing fine, the peach trees drove me off the lot, they have grown so."-J. Y. Bryant. From Ohio.

"I planted over 300 of your trees last year and have lost three trees. some having made a growth of five feet and over."-J. S. Reed. each and every shipment has been very satisfactory. Everything that you have sent me has grown abunFrom Connecticut.

"Will certainly be more than pleased if these trees do as well as for me first, last and all the time." -Lewis R. Eliot.

"Yours for Growing Satisfaction"

NEOSHO NURSERIES CO., Neosho, Mo. with them. The whole transaction icy."-Andrew Walker.

"All told. I have bought some with the stock I have bought of you, with one exception. The trees I got

"Wish to advise that I have received shipment from rou at different times, and wish to state that the others I bought of you. Neosho

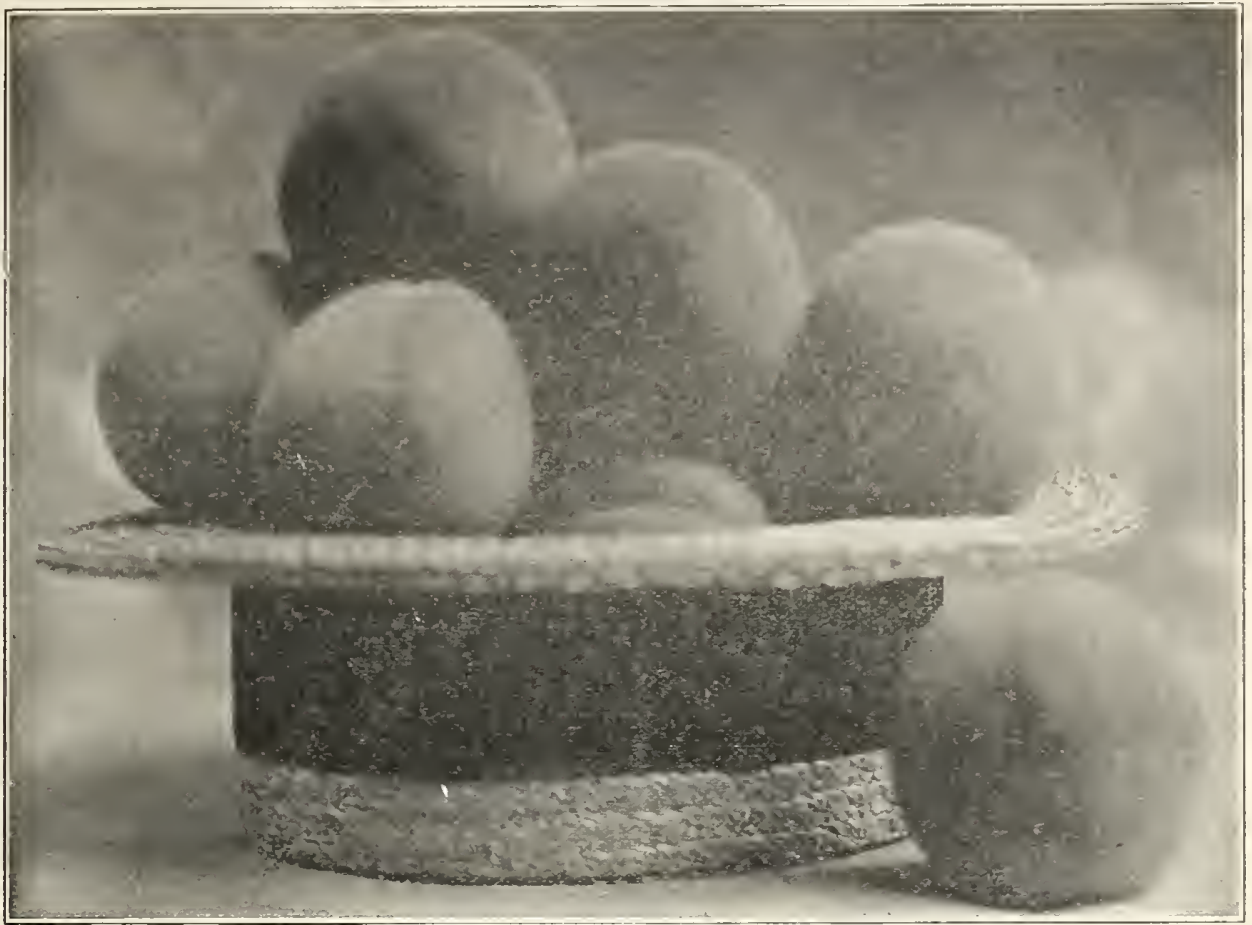

A Hatful of Elberta Peaches

Here are eleven beautiful specimens of Elberta which Mr. Edrington of Osceola, Arkansas, sent us in August, 1926. Another picture of them is at the bottom of the page. They taste even better than they look-truly delectable.

This fruit was grown on trees from Neosho Nurseries. In fact, Mr. Edrington has bought our trees every year except one, beginning with 1917.

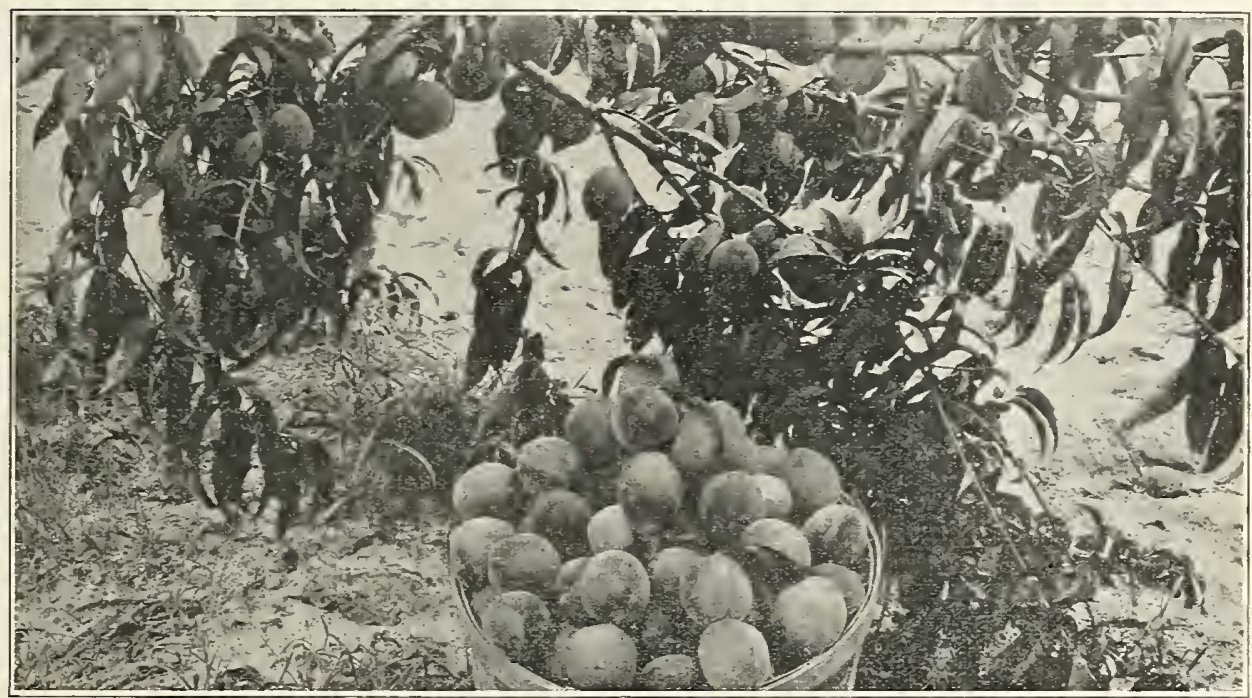

Peaches from Louisiana, from Neosho Nurseries Trees AGAIN TIME PROVES THE VALUE OF NEOSHO TREES

Here is a picture from McNary, La., of Elbertas from Neosho Nurseries trees purchased in the fall of 1921. The new owner sent it to us in August, 1926, also another order in January, 1928.

\section{A Yard of Elberta Peaches}

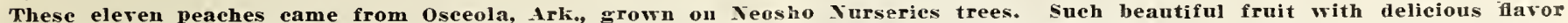
makes the consumex want more regardless of price.

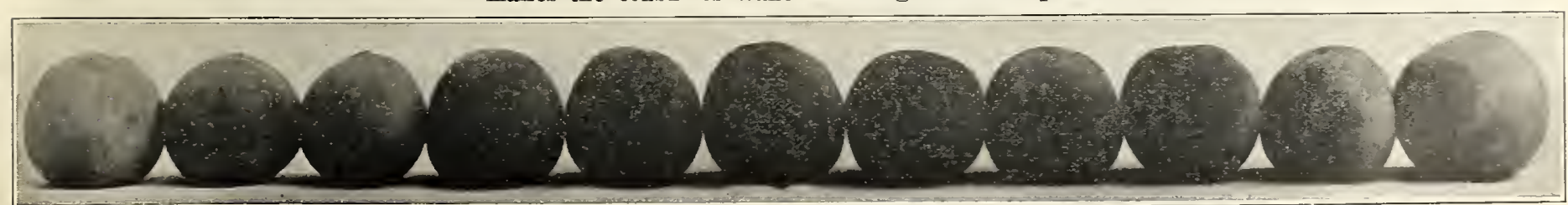




\section{Peaches-None Equal Home-Grown in Flavor}

7 RESH, ripe, home-grown peaches over a season of nearly three months are a most delicious fruit 1 that may be had at little expense. You can never know how good peaches taste until you pick them fully ripened from your trees. They can be grown almost as far north as apples and will succeed farther south. They will do well on a wide range of soil types, even moderately heavy clay loams and clay, but the soil must be well drained. The soil should be moderately fertile. Peaches will not do well on hard impervious clay nor on very alkali soils. Plant largely of midseason and late varieties, but include enough of the earlier and very late kinds to provide an ample supply throughout the season.

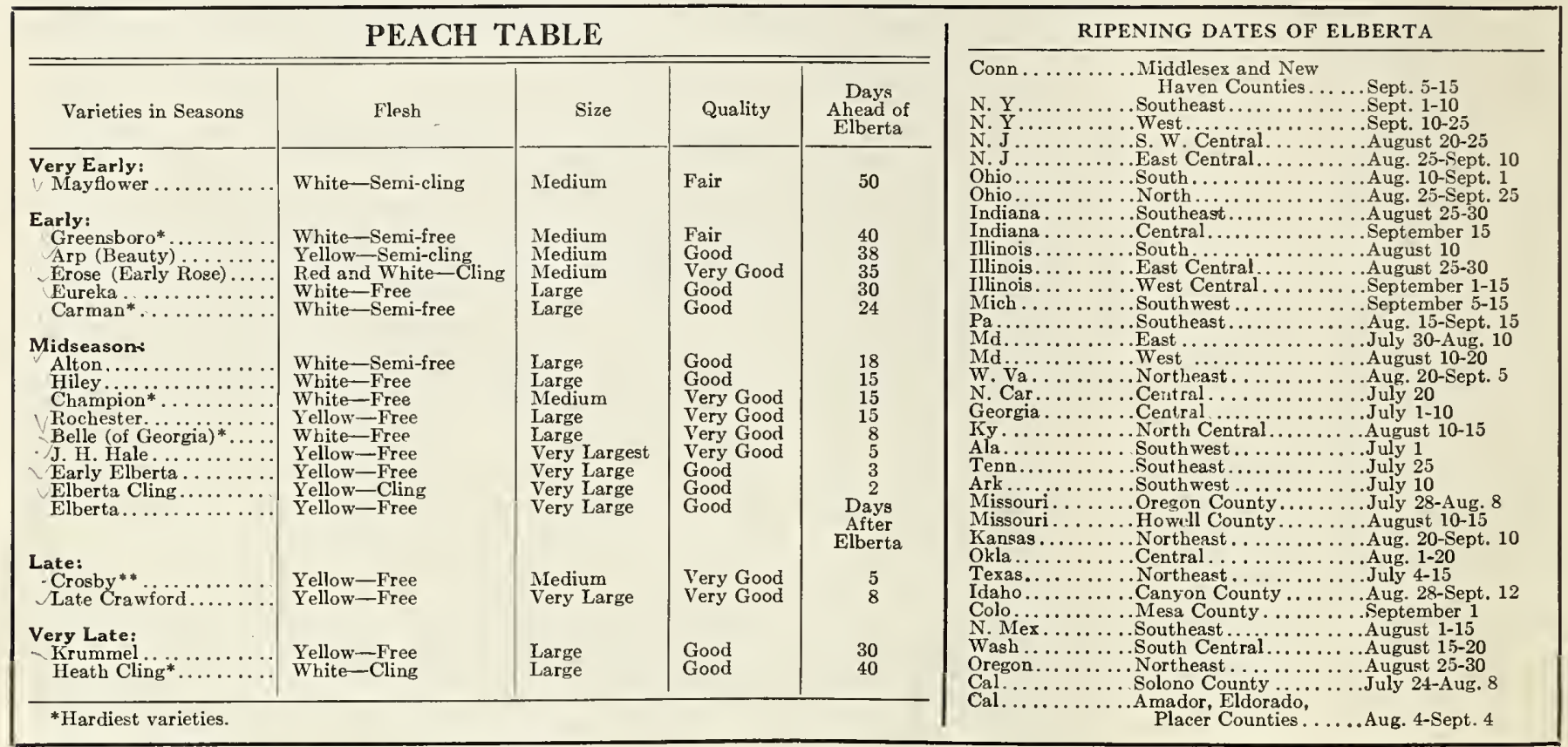

ALTON (White Semi-Freestone) (Midseason)-A large, handsome white-fleshed peach of good quality. Tree is hardy and productive. Blooms early. Grown mostly in Middle West and South.

ARP BEAUTY (Yellow Semi-Clingstone) (Early)-The earliest good yellow peach. Round-oval in shape, heavily blushed with red, excellent quality. Deserves a place in every home orchard. Tree is vigorous, productive, hardier in bud than the average.

BELLE OF GEORGIA (White Freestone) (Midseason)-An unusually handsome large peach. Creamy-white blushed with red, good quality. Tree is large, open headed, hardy. Prefers a Southern or Semi-Southern climate.

\section{One Season's Growth}

Orchard of Peach Trees from Neosho Nurseries at osceola, Ark.,

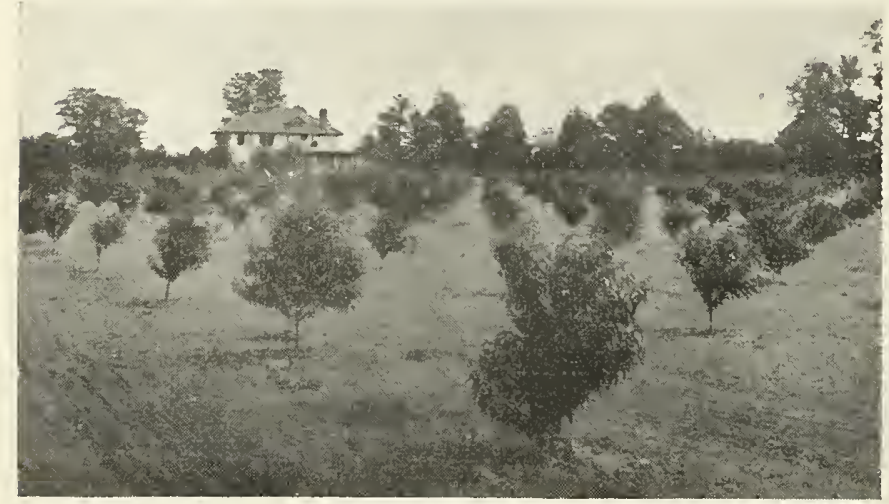

CARMAN (White Semi-Freestone) (Early)-A very general favorite in nearly every peach section as it succeeds in a great variety of soils and withstands trying climates. Tree is an excellent grower, bears abundantly, remarkably hardy in wood and bud. Fruit is brilliant red, splashed with darker red on creamy-white background; good quality for its season.

CHAMPION (White Freestone) (Midseason)-An exceptionally high quality, attractive, hardy white peach. It has a peculiar honeyed sweetness. Not a good shipper but ideal for home use and local markets.

CROSBY (Yellow Freestone) (Late)-Most notable for hardiness of tree and bud. Tree is rather small grower but unusually vigorous, healthy and productive. Fruit is medium size, not attractive, but very delicious for dessert or culinary use.

EARLY ELBERTA (Yellow Freestone) (Midseason)-Very large, high quality, lemon-yellow peach; originated in Utah. Flesh is fine grained, sweet; for home use and local market. Tree is a strong grower of Elberta type. A good bearer under favorable conditions; moderately hardy.

ELBERTA (Yellow Freestone) (Midseason)-The most widely and extensively planted commercial peach. Very large golden-yellow, nearly covered with crimson on the sunny cheek; flesh is firm, rich yellow, fair quality. Tree is a moderately vigorous grower, very productive, yielding large quantities of uniform, highly colored fruit, mediocre in quality; moderately hardy in wood and bud, but its adaptability to all soils, its prolific bearing, large size, splendid shipping qualities, and the tendency to color well before fully mature have made it the great market peach. 


\section{Plant Our Erose For Delicious Early Peaches}

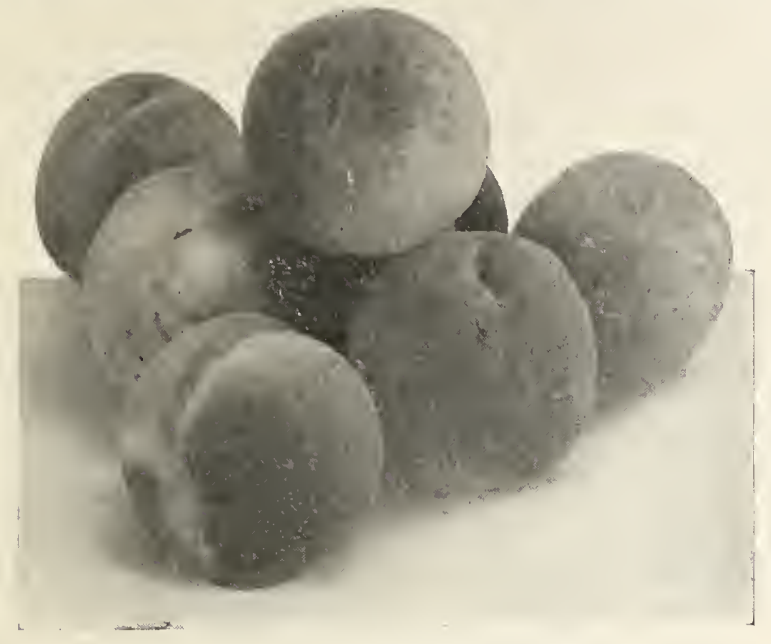

ERosE-A Neosho Introduction.

EROSE (Early Rose) (Red and White Clingstone) (Early)There are several varieties under the name Early Rose. To distinguish ours we are renaming it Erose. This peach originated in Georgia and was introduced by us. It has a delicious sweet flavor, red flesh, medium size and ripens about a month earlier than Elberta. The tree is a medium grower and can be planted closer than such large growing sorts as Belle of Georgia and Carman. Bears young. Most early varieties lack in quality which makes Erose even more appreciated.

EARLY ROSE-(Name changed to Erose. See above.)

ELBERTA CLING (Yellow Clingstone) (Midseason)-The best yellow clingstone; especially fine for canning, preserving and pickling; large, yellow, round, good for dessert. Tree is a strong, vigorous grower, hardy and productive.

EUREKA (White Freestone) (Early)-Very large for an early peach; good quality; white with a distinct red blush on one side; round; flesh is tender, but firm. Tree is above the average size, spreading, semi-hardy to hardy and exceptionally productive.

GREENSBORO (White Semi-Freestone) (Early)-A leading early white peach, owing to its showy fruits and its large, vigorous, healthy trees which are early-bearing and exceptionally prolific. It thrives in a great variety of soil and climates. Somewhat inferior in quality; a good shipper and keeps long.

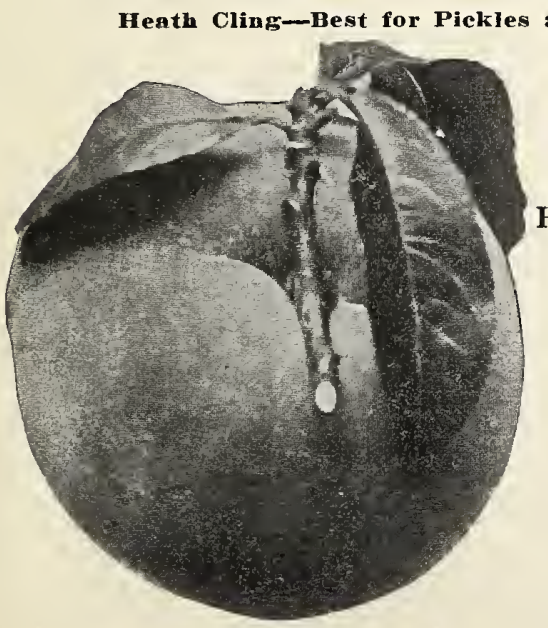

HEATH CLING (White Clingstone) ( $\mathrm{V}$ e r y Late)-The best of all peaches to preserve or pickle whole. The tree is unusually large, healthy and hardy. Exceptionally good keeper, has been known to keep from October to December.
HILEY (White Freestone) (Midseason)-Hiley is the earliest commercial freestone white-fleshed peach; better in quality than most of its competitors; very closely resembles its parent, Belle of Georgia. Flesh is firm, sweet, good quality; a very good shipper; often requires several pickings. Tree is medium size, open, spreading. Productive, but not particularly hardy nor vigorous.

KRUMMEL (Yellow Freestone) (Very Late)-A large, round peach, one side a little larger than the other. A rich golden yellow, blushed with carmine. Flesh is yellow, tinted red at the pit. Firm, melting, rich, subacid, and refreshing. Good quality. A good keeper and shipper. The tree is hardy, healthy and a strong, vigorous grower. It is hardier and more productive than Salway. "The latest peach grown at the station. Ripened October fifth."-Ohio Exp. Station.

LATE CRAWFORD (Yellow Freestone) (Late)-Its high quality, scarcely equaled in richness of flavor, its adaptability to a wide range of soil and climatic conditions make this old variety exceptionally desirable for the home garden. The trees are vigorous, hardy and healthy and the fruit large and very handsome.

MAYFLOWER (White Semi-Clingstone) (Very Early)Earliest peach to ripen. Good size and quality for such an early variety. Creamy white with dark splashes of red; very juicy; fruit ripens unevenly through a long period, making it especially good for home use. Tree is vigorous, upright, spreading and bears very young.

ROCHESTER-Large, yellow freestone with very sweet, delicious flavor. Keeps and ships well. Strong grower, hardy; bears young and regularly.

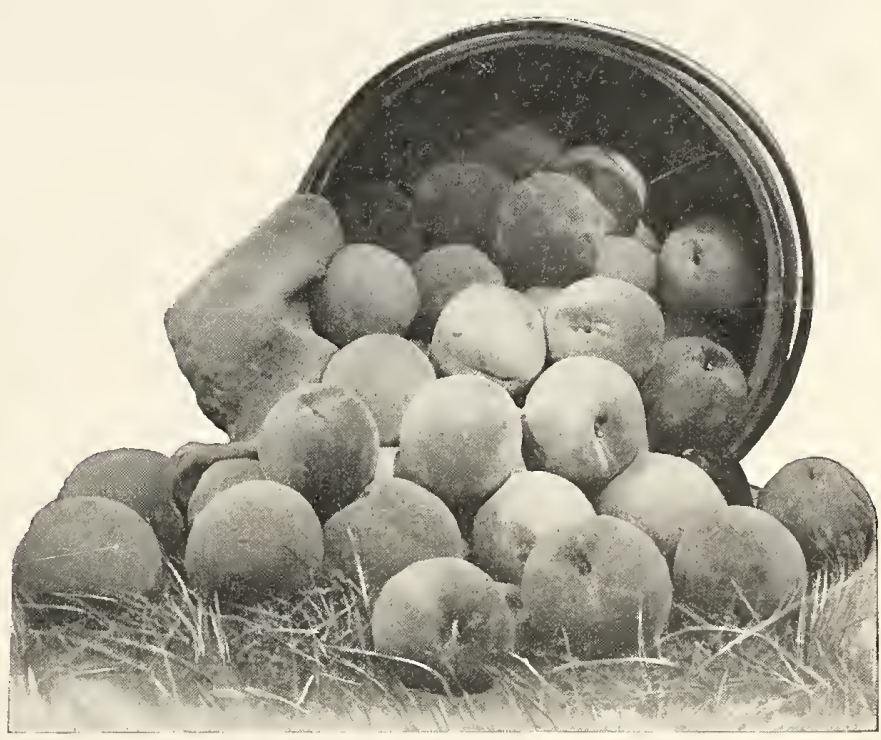

The J. H. Hale (see luside front cover).

J. H. HALE (Yellow Freestone) (Midseason)-This variety was discovered by J. H. Hale over 20 years ago. He sent the fruit from Georgia in an ordinary barrel packed like potatoes to Neosho, where they arrived in splendid condition. Very large in size; it is a beautiful yellow overlaid with red, and has a firm, fine grained yellow flesh of good quality. It colors up a week before maturity, ripens 3 to 7 days ahead of Elberta. The tree is more stocky than the Elberta. It should be planted with some other variety for pollination. 


\section{Pears-Plant a Few in Your Yard}

THE PEAR is one of the highest quality fruits. All pears should be picked before entirely ripe, 1 especially Garber and Kieffer, otherwise the flesh around the core becomes coarse. Pears may be grown wherever apples succeed. They prefer heavy clay and clay loams and on such soils the growth is slower and there is less danger of blight. As a rule, growth should not be stimulated, certainly not with manure. The pear tree is an upright grower and thrives in sod, making it one of the best fruit trees for yard planting.

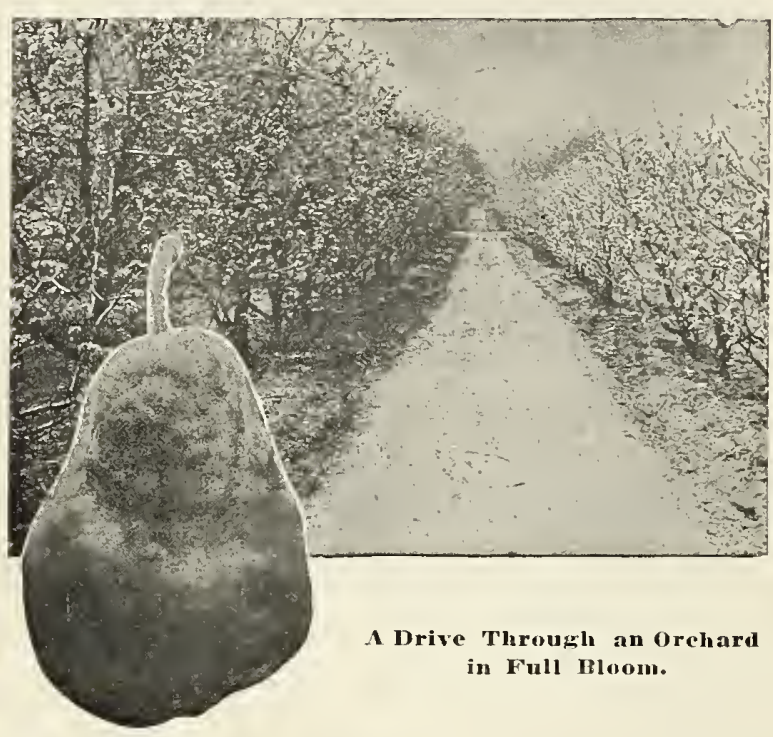

SECKEL (Fall) - The standard of excellence for quality. Small, yellowish brown with russety red cheek; should be first choice for family orchard. Slow grower, dependable, productive and very hardy, notably free from blight. Bears about fourth year. Blooms midseason.

WINTER NELIS (Winter)-The latest, best keeping pear. Can be held in cold storage until spring. Medium-sized, roundish, yellow, russeted pear with a short, heavy neck. Flesh fine-grained, sweet, aromatic, very good quality. Tree is hardy, has wide adaptability, and is a regular bearer. A slender, straggly grower. Blooms late.

\section{Standard Pears}

"Standards" are pears that are propagated on pear roots.

ANJOU (Fall)-Fruit is large, heavy, greenish-yellow with dull red cheek often russeted. Very good quality and keeps late. Tree is hardy, long-lived, productive. Tardy in coming into bearing.

BARTLETT (Late Summer)-The leading commercial variety, one of the most popular for dessert and canning. Large, clear yellow with blush on sunny side. Flesh is white, fine-grained, juicy and sweet. Tree is vigorous, very productive, hardy, bears young.

FLEMISH BEAUTY (Early Fall)-Large, pale yellow, mostly russeted. Very juicy and sweet. One of the choicest when well grown.

GARBER (Fall)-Large, brownish-yellow with red on sunny side; flesh firm, granular, juicy and poor quality. Used for canning. Succeeds farther South where other varieties do not thrive.

KIEFFER (Winter)-Large, yellow russeted; flesh white, rather coarse, poor quality. A market and kitchen variety that succeeds farther South where other varieties fail. If picked when it takes on a slight yellow tint and placed in boxes in a dark place to ripen, they are good to eat out of hand and superior to most pears for canning. Tree hardy, very vigorous, resistant to blight. Blooms early.

LINCOLN (Summer)-Large, yellow, quality good to very good, similar to Bartlett, but more resistant to blight, Succeeds farther south than Bartlett can be grown. It has stood the severest tests of intense, moist, summer heat, and low altitude of the climate at Lincoln, Illinois, where it was originated by W. E. Jones. Comes into bearing early and bears heavy crops annually; very hardy. Blooms midseason.

\section{Picking, Ripening and Storage Dates for Pears}

\begin{tabular}{|c|c|c|c|c|c|c|}
\hline \multirow{2}{*}{ VARIETIES } & \multicolumn{3}{|c|}{ IN NORTHERN STATES } & \multicolumn{3}{|c|}{ IN SOUTHERN STATES } \\
\hline & When to Pick & $\begin{array}{l}\text { When Ripe } \\
\text { Enough to Eat }\end{array}$ & $\begin{array}{l}\text { Latest Cold } \\
\text { Storage Limit }\end{array}$ & When to Pick & $\begin{array}{l}\text { When Ripe } \\
\text { Enough to Eat }\end{array}$ & $\begin{array}{l}\text { Latest Cold } \\
\text { Storage Limit }\end{array}$ \\
\hline $\begin{array}{l}\text { Summer: } \\
\quad \text { Lincoln............. } \\
\text { Bartlett......... } \\
\text { Flemish Beauty.... }\end{array}$ & $\begin{array}{l}\text { July 29-Aug. } 18 \\
\text { Aug. 4-Sept. } 17 \\
\text { Aug. 6-Sept. } 20\end{array}$ & $\begin{array}{l}\text { Aug. } 29-\text { Sept. } 8 \\
\text { Sept. } 10-20 \\
\text { Sept. }\end{array}$ & $\begin{array}{l}\text { Sept. } 15-25 \\
\text { Oct. } 1-15\end{array}$ & $\begin{array}{l}\text { July 19-Aug. } 8 \\
\text { July } 24 \text {-Sept. } 7\end{array}$ & $\begin{array}{l}\text { Aug. 19-31 } \\
\text { Sept. } 1-10\end{array}$ & $\begin{array}{l}\text { Sept. } 5-15 \\
\text { Oct. } 1-15\end{array}$ \\
\hline 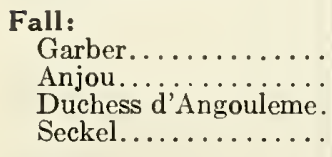 & $\begin{array}{l}\text { Sept. } 4-26 \\
\text { Sept. } 15-20 \\
\text { Sept. } 16-25 \\
\text { Sept. } 17-\text { Oct. } 3\end{array}$ & $\begin{array}{l}\text { Oct. } 6-20 \\
\text { Oct. } 20-30 \\
\text { Oct. } 20-30 \\
\text { Oct. } 6-15\end{array}$ & $\begin{array}{l}\text { Dec. } 1-15 \\
\text { Dec. } 15-25 \\
\text { Dec. } 15-25 \\
\text { Dec. } 15-25\end{array}$ & $\begin{array}{l}\text { Aug. } 26-\text { Sept. } 16 \\
\text { Sept. } 5-10 \\
\text { Sept. } 6-15 \\
\text { Sept. } 7-23\end{array}$ & $\begin{array}{l}\text { Sept. } 26-\text { Oct. } 10 \\
\text { Oct. } 10-20 \\
\text { Oct. } 10-20 \\
\text { Oct. } 15-25\end{array}$ & $\begin{array}{l}\text { Nov. } 10-25 \\
\text { Nov. } 25 \text {-Dec. } 25 \\
\text { Nov. } 25 \text {-Dec. } 5 \\
\text { Nov. } 25 \text {-Dec. } 5\end{array}$ \\
\hline $\begin{array}{l}\text { Winter: } \\
\quad \text { Kieffer ............ } \\
\quad \text { Winter Nelis........ }\end{array}$ & $\begin{array}{l}\text { Sept. } 26 \text {-Oct. } 7 \\
\text { Oct. } 3-20\end{array}$ & $\begin{array}{l}\text { Oct. } 25 \text {-Nov. } 4 \\
\text { Nov. } 6 \text {-15 } \\
\end{array}$ & $\begin{array}{l}\text { Jan. 1-15 } \\
\text { Feb. 1-Mar. } 1 \\
\end{array}$ & $\begin{array}{l}\text { Sep .16-27 } \\
\text { Sept. 23-Oct. } 10 \\
\end{array}$ & $\begin{array}{l}\text { Oct. } 15-25 \\
\text { Oct. } 15-26 \\
\end{array}$ & $\begin{array}{l}\text { Dec. 1-5 } \\
\text { Jan.-Feb. }\end{array}$ \\
\hline
\end{tabular}




\section{Dwarf Pears-Beautiful, Useful in Garden or Yard}

THE PEAR can be grown more satisfactorily as a dwarf than other fruits. It is especially good for planting in small yards and gardens. It is propagated on quince roots, which make the tree a slow, dwarfish grower, and less subject to blight than standard pear trees. The fruit is the same as that of standard trees.

They come into bearing young, often in the second or third year and are very productive. "It is the common belief that dwarf pears are short-lived but this is not necessarily true."-Prof. W. L. Howard. They can be set close together, usually 10 to 15 feet apart; hence they are especially valuable for home gardens and small yards, where they are ornamental as well as useful. They should be planted 4 or 5 inches deeper than they stood in the nursery row. Since they should never be more than 12 feet tall it is often necessary to remove one-half to two-thirds of the annual growth late each winter.

DUCHESS d'ANGOULEME (Fall)-Best when grown as a dwarf. The largest of the good pears; white flesh, rich, good quality. Tree is hardy, upright grower, productive and long lived.

\section{Superb Apricot}
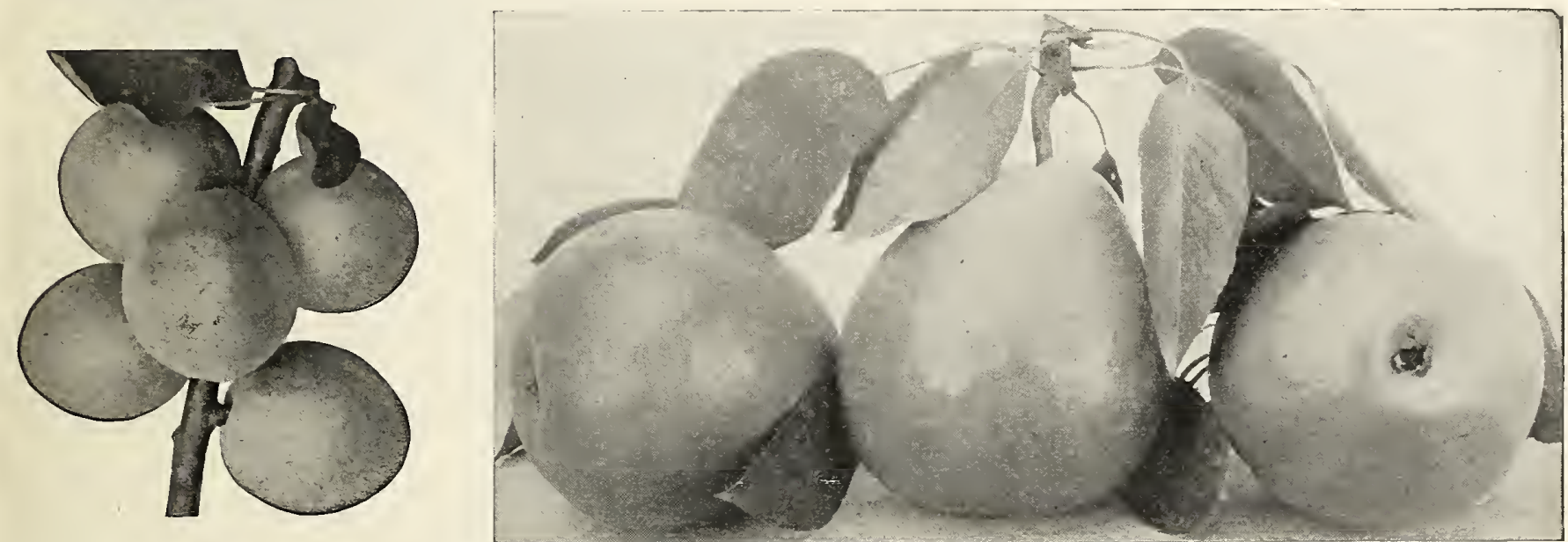

\section{Apricots Have a Flavor Unlike any Other Fruit}

T

HE APRICOT is one of the most delightfully luscious fruits grown, when eaten fully ripe and fresh

from the tree. It is remarkable that such a rich and beautiful, golden, sweet fruit is not planted more, especially since it ripens just after the early cherries and before the best early peaches. Apricots succeed in many localities and will stand more winter cold than peaches, although the bloom is more apt to be injured by spring frosts. The soil should be well drained, the subsoil as well as the surface. A northern or western slope is best so the opening of the buds will be retarded and the danger of frost damage lessened.

SUPERB (Freestone)-The best apricot for Eastern planting; medium size; roundish oval; smooth, light salmon color, with numerous red dots; flesh is yellow, firm, sub-acid; very good. The tree is a very hardy Russian type, a vigorous grower; very productive; latest-blooming apricot; is adapted to peach regions.

\section{Quince Adds a Delicious Flavor to Other Fruits}

THE QUINCE is the ideal fruit for flavoring preserves, jellies, marmalade and cooked fruit. Trees 1 thrive on well-drained, fairly rich soil, are long-lived, and, being small, dwarfish growers, can be planted closely. They are especially suited for yards and gardens.

ORANGE-The most widely grown quince. Golden color, large, roundish shape, short neck. Can be kept until January or February. One of the best for all purposes.

REA'S (Mammoth)-Rich, orange color, roundish, pearshape, tapering neck. Very good quality for flavoring other fruits and for baking; almost fuzzless.
VAN DEMAN-Unusually large, often weighing one pound or more; rich orange color; round, chunky shape; heavy, firm flesh; especially good quality; bears young, often second or third year on fertile ground.

Well cared for trees often bear abundantly for rorty years. 


\section{Plum-A Source of Delight in the Yard}

DLUMS are especially fine for eating fresh, for jeilies, preserves and marmalade, and unexcelled for 1 canning and drying. Some varieties will thrive wherever apples or peaches can be grown. Most of them bear the third or fourth year. One of the best fruit trees for the home garden.

ABUNDANCE (Early)-A pinkish-red Japanese plum, covered with a thin bloom. Medium size, roundish oval. Flesh is yellow, tender, melting, unusually juicy and refreshing; sweet, aromatic; quality good to very good. Tree is a vigorous grower, large, hardy and very productive. Adaptable to wide diversity of soils and climates, bears heavily and regularly. Should be picked before quite ripe; dropping and rot are thus avoided and flavor is better. Blooms early.

BRADSHAW-Medium to large; dark purplish red with yellowish dots and blue bloom. Flesh greenish-yellow. Good quality. Flavor rich, sweet. Midseason. Tree a good grower. Blooms very late.

BURBANK (Midseason)-A dark red, roundish Japanese plum; better quality and shipper and less susceptible to brown rot than Abundance. The flesh is a deep yellow, firm, very juicy, aromatic, and sweet; quality good to very good. The tree is healthy, not quite as fast a grower as Abundance; flat, spreading top. A week later than Abundance. Blooms very early.

FRENCH DAMSON (Late)-Largest and best quality of the Damsons. Dull purplish-black color. Flesh very juicy, tender, sweet, pleasant, and good quality. Tree large, vigorous, spreading, hardy and productive. Ripens a little later than Shropshire. Blooms midseason.

REINE CLAUDE (Green Gage-Midseason)-A large, roundish, oval plum; light greenish-yellow. Firm, sweet, mild, rich flavor, very juicy, aromatic; good to very good in quality. Tree is of medium size and vigor, productive, and hardy. Thrives best on light, sandy soils. Chief defects: Susceptible to sunscald and fruit cracks if showers occur at ripening time. Blooms midseason. Should be in every home garden.

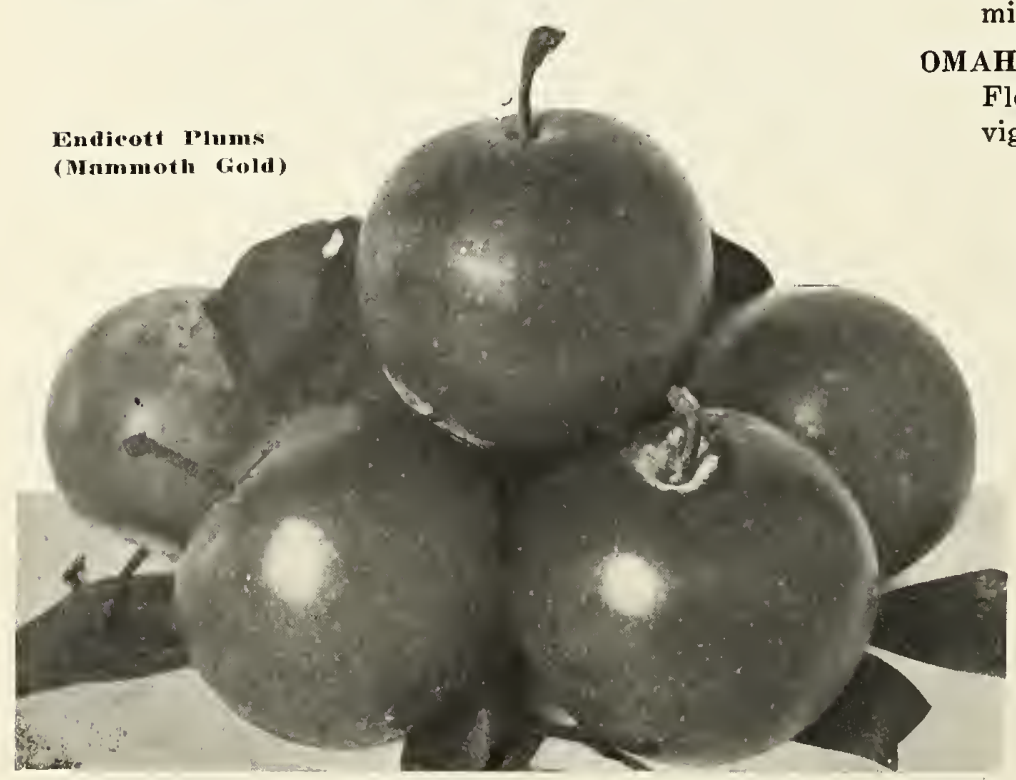

AMERICA (Midseason)-An improved Gold, originated by Burbank; a beautiful waxen yellow, with currantred cheek. Flesh is yellow, juicy, sweet, very good forcooking. Th e tree is a large, strong grower, spreading, o p e $n$ t o p ; extremely hardy and productive, and succeeds where others fail. Considering its parentage, phenomenally f ree from rot. Midseason bloomer.

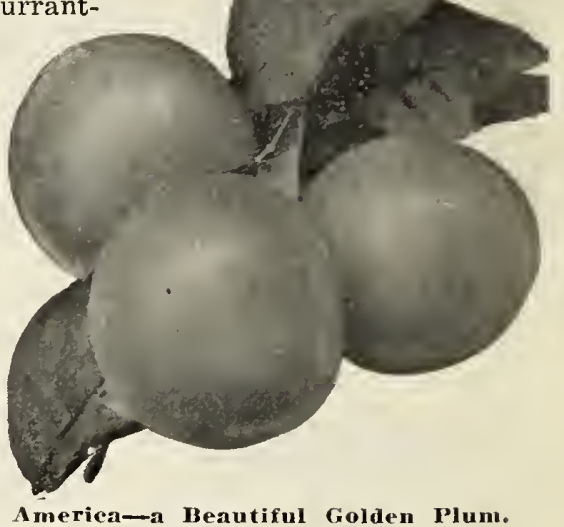

ITALIAN PRUNE (Late)-The Italian, or Fellenburg, is the largest, best and one of the most widely grown of all prunes. Long, oval shape, rich, purplish-black; almost dark wine color, overspread with a thick blue bloom. It is a very large size, flesh firm, yellow, aromatic, juicy, rich, sweet and very good to best quality. Fine flavor for dessert and cooking. Keeps and ships well. Succeeds everywhere except in the more Southern states. Late bloomer.

LOMBARD (Midseason)-The most widely planted plum in America, noted for hardiness and dependability; adaptable to widely different soils and climates, unusually healthy, very productive, regular bearer and fruit is comparatively free from attacks of the curculio. Medium to large size and oval shape; purplish-red or reddishviolet color, overspread with a thin bloom; easily sold because of its beauty. It is inferior in quality, but does very well for cooking, canning and preserving. Blooms midseason.

MAHA (Early)-A large, round, brilliant, coral-red plum. Flesh is firm, yellow, juicy and sweet. Tree is a strong, vigorous grower, hardy and productive.

ENDICOTT (Midseason)-Endicott combines the high quality of the European with the hardiness and adaptability of the Japanese. One of the sweetest, juiciest plums. It averages very large in size, roundish, slightly flattened at the end; dark garnet-red, with a faint bloom. Flesh is a light yellow, firm and rich. Mr. Endicott, the originator, of Southern Illinois, wrote of this plum:

"I have fruited it side by side with Red. June and Gold, and I think it is worth more than both of them put together. In fact, it is the best plum I have ever seen for our low elevation and changeable climate. It generally ripens here about the Fourth of July. By thinning and spraying them with self-boiled lime-sulphur, I have grown them two inches in diameter." 


\section{Plums Are Easy to Grow and Bear Young}

RED JUNE (Early)-A large garnet-red, heart-shaped Japanese plum, pointed at tip. Flesh is light yellow, meaty, sweet, peculiarly aromatic; quality fair to good. Tree is a large, vigorous, upright, spreading grower; very hardy and productive. Should be planted with other varieties for the purpose of cross-pollination. Abundance and Burbank are good pollenizers for this variety. Usually ripens a week before Abundance. Blooms early.

SHROPSHIRE DAMSON (Late)-The most widely planted Damson. Oval shape; purplish-black covered with a thick bloom; flesh is juicy, firm, tender, sprightly and pleasant. Tree is strong, vigorous grower, quite hardy. A standard for productivity and reliability in bearing; fair for eating when fully ripe or after a light frost; one of the best for culinary purposes. Fruit ripens late over a long season. Blooms late.

WILD GOOSE (Very Early)-An old-time favorite; bright red; medium size; flesh is yellow, very juicy, tender, melting, very sweet except slightly acid next to the seed; quality fair to good. This is a very large, strong, flattopped grower; hardy. Good shipper and keeper; comparatively free from brown rot and curculio. The Wild Goose is a native plum and should be planted near other plums of this class for pollenization. Blooms medium early.

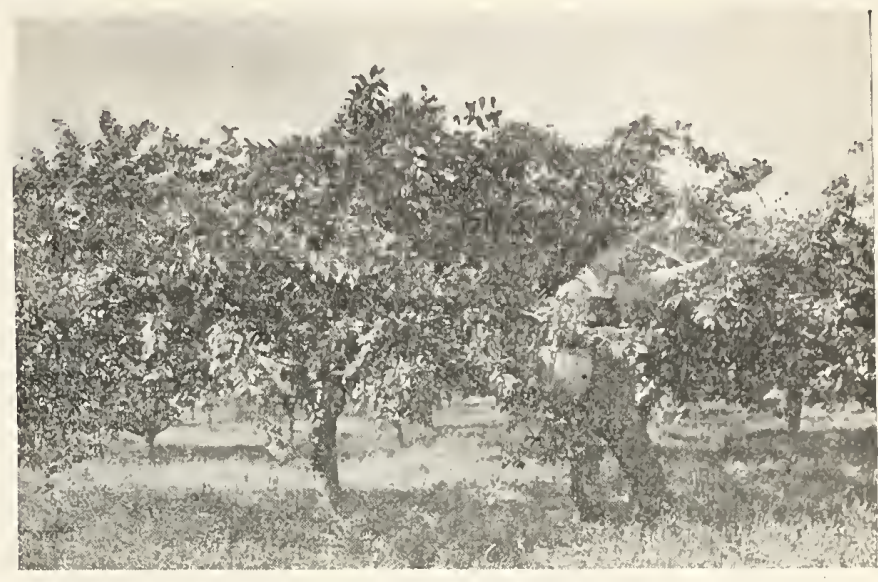

Burbank Plum Trees.

SATSUMA-Large, dark brilliant red. Flesh dark red, good quality. Flavor rather acid. Ripens medium to medium late. Sterile. Not as hardy as Bradshaw. Tree, spreading. Blooms early.

WICKSON_Large to very large, dark red. Flesh yellow, quality good. Flavor sweet. Season medium. Tree upright grower. Blooms early.

\begin{tabular}{|c|c|c|c|c|c|c|}
\hline VARIETIES & RIPENS & BLOOM & QUALITY & SIZE & HARDINESS & COLOR \\
\hline 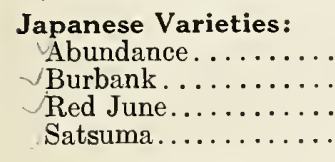 & $\begin{array}{l}\text { Early } \\
\text { Early } \\
\text { Early } \\
\text { Medium }\end{array}$ & $\begin{array}{l}\text { Early } \\
\text { Early } \\
\text { Early } \\
\text { Early }\end{array}$ & $\begin{array}{l}\text { Good } \\
\text { Very Good } \\
\text { Fair } \\
\text { Good }\end{array}$ & $\begin{array}{l}\text { Medium } \\
\text { Medium } \\
\text { Medium } \\
\text { Large }\end{array}$ & $\begin{array}{l}\text { Hardy } \\
\text { Hardy } \\
\text { Hardy } \\
\text { Half-hardy }\end{array}$ & $\begin{array}{l}\text { Bright Red } \\
\text { Dark Red } \\
\text { Dark Red } \\
\text { Dark Red }\end{array}$ \\
\hline 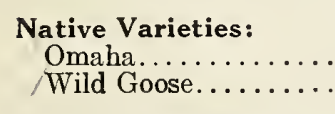 & $\begin{array}{l}\text { Early } \\
\text { Very Early }\end{array}$ & Medium & $\begin{array}{l}\text { Good } \\
\text { Fair }\end{array}$ & $\begin{array}{l}\text { Large } \\
\text { Medium }\end{array}$ & $\begin{array}{l}\text { Very Hardy } \\
\text { Hardy }\end{array}$ & $\begin{array}{l}\text { Light Red } \\
\text { Bright Red }\end{array}$ \\
\hline 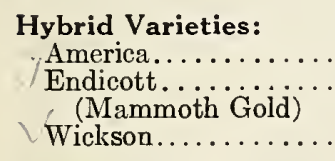 & $\begin{array}{l}\text { Medium } \\
\text { Early } \\
\text { Medium }\end{array}$ & $\begin{array}{l}\text { Medium } \\
\text { Medium }\end{array}$ & $\begin{array}{l}\text { Medium } \\
\text { Good } \\
\text { Good }\end{array}$ & $\begin{array}{l}\text { Medium } \\
\text { Large } \\
\text { Very Large }\end{array}$ & $\begin{array}{l}\text { Half-hardy } \\
\text { Hardy } \\
\text { Half-hardy }\end{array}$ & $\begin{array}{l}\text { Golden Yellow } \\
\text { Dark Red } \\
\text { Dark Red }\end{array}$ \\
\hline 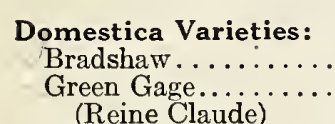 & $\begin{array}{l}\text { Medium } \\
\text { Medium }\end{array}$ & $\begin{array}{l}\text { Medium } \\
\text { Medium }\end{array}$ & $\begin{array}{l}\text { Good } \\
\text { Best }\end{array}$ & $\begin{array}{l}\text { Medium } \\
\text { Medium }\end{array}$ & $\begin{array}{l}\text { Hardy } \\
\text { Hardy }\end{array}$ & $\begin{array}{l}\text { Purplish-Red } \\
\text { Yellow }\end{array}$ \\
\hline $\begin{array}{l}\text { Italian Prune............ } \\
\text { Lombard......... }\end{array}$ & $\begin{array}{l}\text { Late } \\
\text { Medium }\end{array}$ & $\begin{array}{l}\text { Late } \\
\text { Medium }\end{array}$ & $\begin{array}{l}\text { Good } \\
\text { Fair }\end{array}$ & $\begin{array}{l}\text { Large } \\
\text { Medium }\end{array}$ & $\begin{array}{l}\text { Hardy } \\
\text { Very Hardy }\end{array}$ & $\begin{array}{l}\text { Dark Blue } \\
\text { Purplish-Red }\end{array}$ \\
\hline 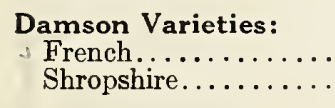 & $\begin{array}{l}\text { Late } \\
\text { Late }\end{array}$ & $\begin{array}{l}\text { Medium } \\
\text { Late }\end{array}$ & $\begin{array}{l}\text { Good } \\
\text { Fair }\end{array}$ & $\begin{array}{l}\text { Small } \\
\text { Small }\end{array}$ & $\begin{array}{l}\text { Very Hardy } \\
\text { Very Hardy }\end{array}$ & $\begin{array}{l}\text { Dark Blue } \\
\text { Dark Blue }\end{array}$ \\
\hline 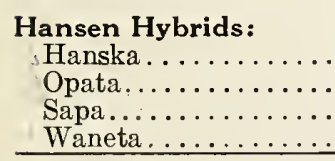 & $\begin{array}{l}\text { Very Early } \\
\text { Very Early } \\
\text { Very Early } \\
\text { Very Early } \\
\end{array}$ & $\begin{array}{l}\text { Medium } \\
\text { Medium } \\
\text { Medium } \\
\text { Medium } \\
\end{array}$ & $\begin{array}{l}\text { Very Good } \\
\text { Good } \\
\text { Good } \\
\text { Very Good }\end{array}$ & $\begin{array}{l}\text { Large } \\
\text { Large } \\
\text { Medium } \\
\text { Very Large }\end{array}$ & $\begin{array}{l}\text { Very Hardy } \\
\text { Very Hardy } \\
\text { Very Hardy } \\
\text { Very Hardy } \\
\end{array}$ & $\begin{array}{l}\text { Bright Red } \\
\text { Dark Red } \\
\text { Dark Purple } \\
\text { Red } \\
\end{array}$ \\
\hline
\end{tabular}

The Italian Prune is a freestone. The others are cling or semi-clings.

\section{Hansen's Hybrid Plums}

$\mathrm{O}$ RIGINATED by Prof. Hansen of the South Dakota Agricultural College. They are exceptionally hardy and also withstand extremely hot, dry weather, bear very young and heavily and are the first plums to ripen. Good for dessert and cooking.

HANSKA-Good size, about $1 \frac{112}{2}$ in. in diameter, bright red. Flesh reddish; flavor delicious. Very good quality. Tree strong, upright; vigorous.

OPATA-Size 1 in. or more in diameter, dark red. High quality. Bears second year. Tree often grown in bush form.
SAPA-Dark glossy purple. Flesh purple-red. Fine flavor. Bears early and heavily. Tree is spreading and handsome in appearance.

WANETA-Very large, 2 in. in diameter. Delicious quality. Regarded as the best of the Hansen hybrids. 


\section{Home Grown Berries Are Truly Delectable \\ Blackberry and \\ Raspberries} Dewberry

City people do not know the really delectable flavor of fully ripe blackberries, since, even for local markets, they must be picked before they are fully ripe and they do not ripen in transit. The cultivated varieties are much juicier and larger and better in quality. They are easily grown and bear abundantly the second year.

EARLY HARVEST (Early)-Glossy black, medium size, good quality not very hardy, requiring protection in the North DORADo (Midseason)-Medium to large, jet black, sweet
and melting, very good quality; very hardy; vigorous and
productive.

McDONALD (Very Early)-A blackberry-dewberry hybrid. It is large, oblong, very good quality; drouth-resistant, vigorous grower; plant in rows eight to ten feet apart. The vine trails on the ground the first season like the dewberry but grows upright the next year. Grown in Missouri, Oklahoma and Texas. Not hardy and is self-sterile. Plant every fourth row with Lucretia Dewberry or Early Harvest to develop good berries.

LUCRETIA (Very Early)-The best known and most widely planted dewberry. The berries are large, long, firm and good quality, very sweet if left on the vines a day or two after they would be picked for shipping.

\section{Cultural Directions}

Where winters are mild flant in the fall but mulch with straw or coarse manure for winter protection.

Plant 3 feet or more apart in rows 5 feet or more apart. Set an inch or two deeper than in the nursery row and cut back the tops to 6 inches or less.

Cultivation should begin as soon as the plants are set and continued every week or two until a month before freezing weather. Pinch off the tops of the young canes when at height of $21 / 2$ feet- 3 feet. Immediately after ficking, old canes should be cut out and burned and also all but 3 or new canes to each plant

A wire trellis is often used. Posts are set 15 to 30 feet apart in the row and the canes tied to a wire about $2 \frac{1}{2}$ feet above the ground.

"Trees and plants from your nursery are thrifty and have proven very satisfactory."-Septcmber 6, 1926, Smith and Ray, Madison County, Mississippi.

\section{Gooseberries and Currants}

Are used chiefly in making jams, jellies, preserves, pies, tarts, etc. They contain a large amount of pectin, which is necessary for jelly making. Gooseberries are grown slightly farther south than Currants, suffering less from hot, dry weather. Bear second or third year.

\section{Currants}

LONDON MARIKET CMidseason to Late)-Very hardy. Medium to large, dark red rather acid. Clusters compact.

PERFECTION (Midseason) Large, bright red berry in lon $g_{\text {, compact clusters }}$ ous and productive.

WHITE GRAPE-The best white currant. Large clusters of white or goldengreen berries, mildly acid in flavor; slender but producive grower.

Cultural Directions

Plant in fall except where winters are severe. If placed permanently among fruit trees the foliage plants more productive in such locations.

Set 4 feet apart in rows 6 feet apart.

Broken roots should be cut off and the tops cut back to within about 6 inches of the they stood in the nursery.

\section{Gooseberries}

DownrvG-The most widely grown variety; medium to large; pale green. Vigorous, and very productive; rarely
attacked by mildew. OREGON (Champion) - A large green berry, season late. Very productive, rarely attacked by mildew. An improved variety which combines the large size and high quality of the Downing with the productiveness

\section{Cultural Directions}

The soil should be cool, well drained and very fertile. Silt or clay loams are best. Cultivate frequently during the growing season After the first year the cultivation should be shallow.

Liberal quantities of stable manure and wood ashes will generally prove profitable.

The currant worm attacks both gooseberry and currant and should be sprayed as soon as they appear with arsenate of lead, $1 \mathrm{lb}$. powder or $2 \mathrm{lbs}$.
paste to 50 gallons of water.
This tempting fruit is easy to grow and is produced the second season after planting.

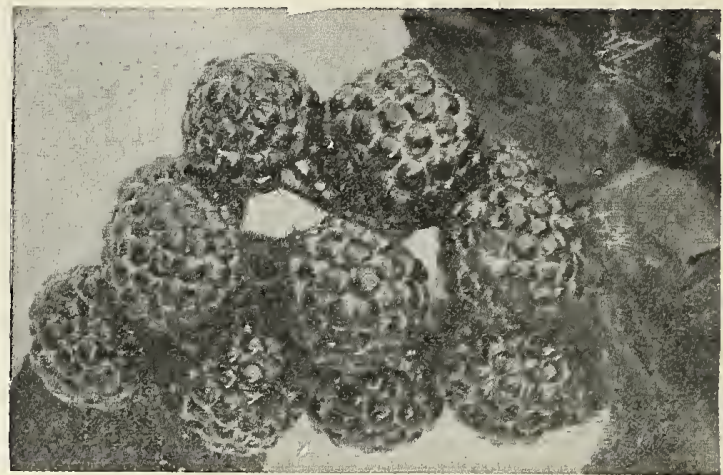

Cumberland Raspberry-Very Productive, Extra Good Quality.

CARDINAL (Purple)-Most popular purfle variety in Missouri. Hardy and drought resistant.

CUMBERLAND (Black) (Midseason)-The most widely planted black raspberry because of its productiveness and quality. Berries are extra large, fine and sweet

CUTHBERT (Red) (Late)-The best red because of its superior quality and flavor. Berries are large, rich crimson, firm and one of the best for canning.

KANSAS (Black) (Early to Midseason)-Large, firm, sweet, well-flavored berries and strong, prolific canes, resistant to drought.

RANERE (St. Regis) (Red) (Everbenring)-Bright red, small to large berries. Canes are hardy, prolific, healthy, drouthresistant. Bears very early; after old canes have borne the young canes begin bearing and produce until frost. of first crop will be small and no second crop may form. Succeeds further south than other varieties.

\section{Cultural Directions}

May be planted in the fall where winters are mild, but hould be mulched with straw or coarse manure for winter protection. Usually spring is the best time, esfecially with black or purple varieties.

Space plants 2 to 4 feet apart, in rows 5 to 8 feet afart, red varieties closer than blacks. Set an inch or two deeper than they stood in the nursery, in good rich soil; ground bone is a good fertilizer. Keep well cultivated and free from weeds and suckers. Pinch back the young canes of black raspto grow on the canes and makes the bushes more stocky and self-supporting. The next spring cut the side branches back a third to a hall.

Red raspberries require no pruning excert where the canes are very tall they may be cut back to 5 or 6 feet in height.

Leave not more than 4 or 5 canes per plant, except possibly with very vigorous growers. Remove and burn old canes when the crop has been picked.

The dewberry trails on the ground and the tops are usually tied to stakes or wires in the spring. In cold climate a mulch of straw or earth is necessary in the winter.

Ranere (St. Regis) Raspberry-Bears two crops, spring and fall.

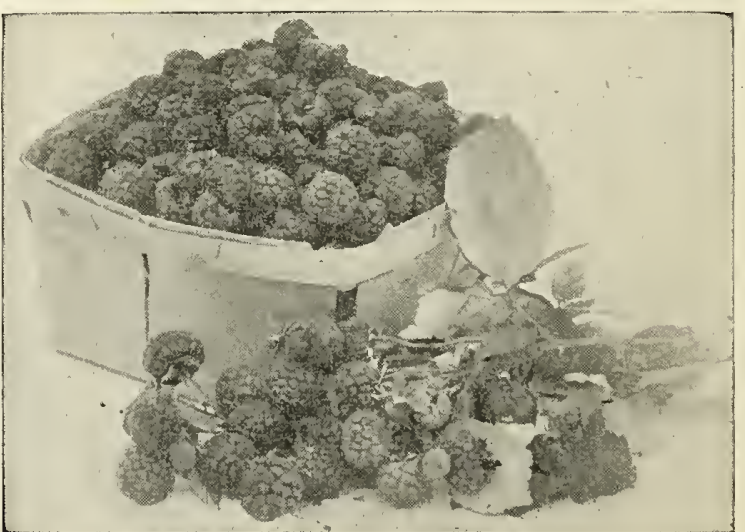

"I will certainly OUR METHODS PLEASE business metlods. You are at liberty to refer to me whenever you vish."-March 21, 1926. George C. Langston, Arkansas. 


\section{Every Garden Should Have These Good Things \\ Strawberries \\ Asparagus}

Are the first fruit to ripen in the spring. Fresh or preserved, they are delicious and healthful, and help out on the grocery bill. Like blackberries and raspberries, they reach their highest quality when fully ripened before picking, which is not the case when grown for market. They do well on almost any soil if well drained, deeply worked, and well fertilized. Standard varieties produce good crops the next spring after planting.

All the following varieties are self-fertile and can be planted alone.

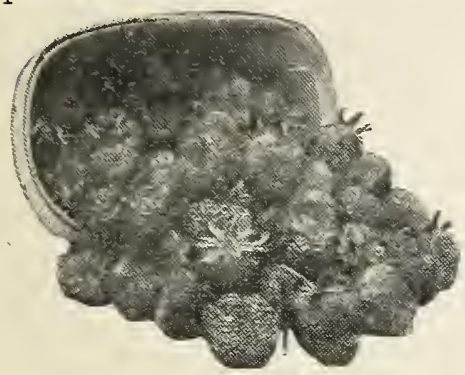

The Everbearing will produce the first summer and fall. The second year they bear in the spring and continue fruiting until severe frost comes. They are particularly fine for the home garden. Fifty to one hundred plants set about a foot apart in beds 4 to 5 feet wide will supply a small family with berries throughthe season.

\section{Standard Varieties}

AROMA (Midseason to Late)-A richly colored, large berry, deliciously aromatic in flavor. Ripens over a long season. dts chief merits are resistance to disease, productiveness Its chief merits are resistance to disease, croductivent. and attractiveness, frm clay soils. 125,000 crates, 24 quarts Best adapted to silt or clay soils. 125,000 crates, 24 quarts each, were shipped out of Neosho ingland, Canada, ColoAroma. They were sent to New Englan

(Senator) DUNLAP (Midseason)-One of the most widely flanted varieties. Noted for dependability and productiveFlanted varieties. Noted for dependability and productive-
ness. A medium sized handsome berry, deep glossy red, ness. A medium sized handsome berry, deep glossy red, hardy and drouth-resistant. Adapted to any type of soil and wide variation in climate.

OZARK (Early) (Extra Early)-Dark red, excellent quality berry, large for their season. The plant is vigorous and productive.

PROGRESSIVE (Everbearing)-Bear first summer and fall, second year in spring and fall. The berries are medium size, dark crimson, and delicious in quality. The plant is unusually healthy, vigorous, very hardy and productive. It needs a rich soil amply supplied with moisture. If an early frost catches one set of blossoms, another is formed
immediately. The first season the blossoms and runners should be cut off until about the middle of July.

\section{Cultural Directions}

Cover the ground with well-rotted manure-a wheelbarrow load to each 100 square feet. Plow or dig the ground and pulverize deeply and thoroughly.

Do not plant in ground that has just been in sod; if you do, the white grubs will probably destroy the plants.

Cut back the roots to about 4 inches and put them in water. Be particularly careful to set plants the correct depth, the crowns just level with the surface, and firm the soil about the roots.

Cultivate about once a week, and only an inch or two deep, but not when the ground is wet.

Keep the blossoms picked off the first season on standard varieties and until about July 1st on Everbearers.

The hill system produces the largest and finest berries. The plants are set 18 to 24 inches apart each way, which allows cultivation both ways, or 15 to 18 inches between plants in rows 24 to 30 inches apart. In either case all runners must be cut off as soon as they appear.

"In the spring of 1925 I got 100 Progressive Everbearing Strawberries from you, also 100 from another nursery. It was an awful dry season with us. Your plants pulled through the drought somehow while the other plants all died but ten. This summer I have enjoyed berries all summer, also set 400 plants from them."September 4, 1926, H. H. Swearingen, Wright Co., Missouri.

\section{Horseradish}

The best quality and largest size is produced in a deep loam, moderately rich, well supplied with humus; good drainage and a fairly open subsoil are essential. 2 Plant about 18 inches apart in rows 3 feet apart and cover needed to keep down weeds and conserve moisture.
Every home garden should have asparagus, one of the earliest and most wholesome vegetables, and when canned retains its flavor better than most vegetables.

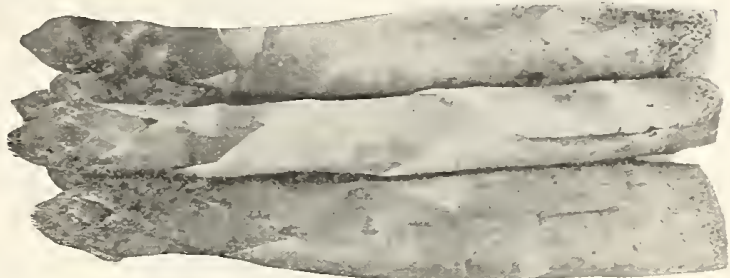

WASHINGTON-The most resistant to rust and is also superior in color, size and flavor.

Prefers a sandy loam but succeeds on nearly all kinds of Plow deep and mix in thoroughly 2 or 3 inches of well-rotted mature. Set plants 15 inches apart in rows 3 feet apart. Cover the erown or top about

Frequent shallow cultivation is necessary to conserve moisture and keep down the weeds.

Early in fall, cut the stalks close to the ground and remove from the patch. Cover with coarse manure 3 inches deep. Early in spring remove all but the fine manure, which should e forked into the ground

cut few, if any, shoots until third season.

Apply a pound of salt to about 128 square feet.

\section{Rhubarb}

Is hardy in all parts of the temperate zone. Comes at an early season when most needed and appreciated.

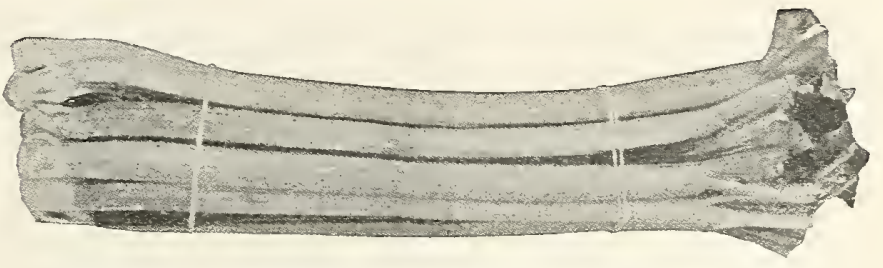

Plant in fall or spring, 3 feet apart in rows 4 feet apart.

The crowns should be barely covered with dirt. If planted deep they are almost sure to rot during the hot weather of the first season.

Thorough cultivation should be given through the summer and liberal afplications of manure every winter.

In gathering the leaf stalks, the base of the stalk should be pulled out, for if broken off at the surface of the ground the rotting of the short piece left causes "stem rot."

The Right and Wrong Way to set Strawberry Plants.

A-Too Shallow B-Too Deep C-Just Right

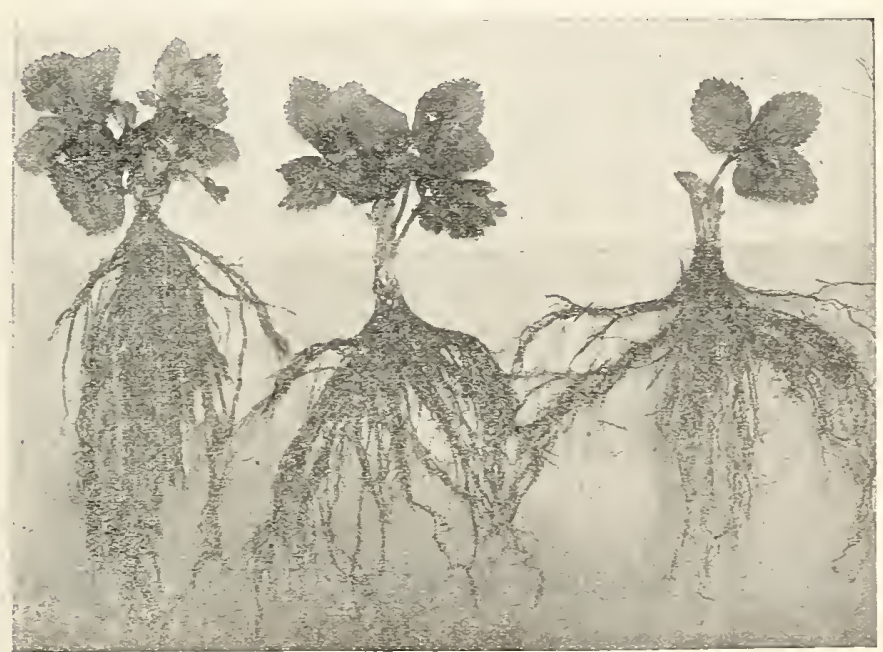




\section{Grapes Give Great Satisfaction and Profit}

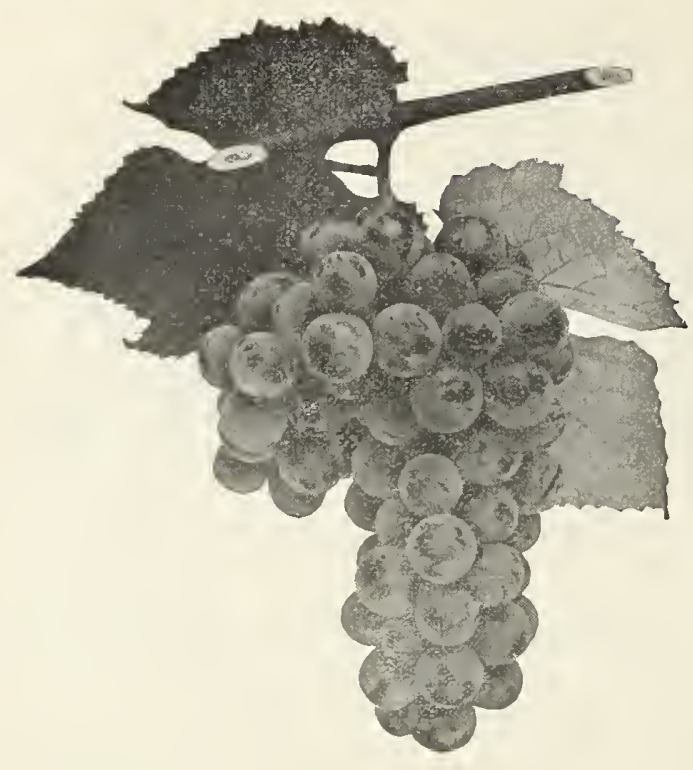

THE GRAPE is the surest, most dependable of fruitshardy, vigorous, productive-and begins to bear the second or third year. Every yard or garden should have a few grapevines. They take little room, are quite ornamental trained over arbors, fences, walls or buildings, and they also produce good fruit in spite of neglect or unfavorable conditions. Of course, they respond quickly to care and attention; especially do they require severe pruning. Some varieties are sterile (marked *) and must be planted near others for cross-pollination.

If the soil is poor or not well drained, the home grower can easily provide a remedy. There are vines still bearing at least 300 years old. It is worth while then if necessary to dig a generous hole 2 feet deep, put a pailful of old bones in the bottom, cover them with good earth and plant the vine.

\section{How to Plant}

Grape vines are usually planted in the spring. If set in the fall, mulch them heavily or mound the dirt up over the top to prevent injury from alternate freezing and thawing. This mulch or dirt must be removed in the spring. Set $8 \mathrm{ft}$. apart in rows $10 \mathrm{ft}$. apart. Cut back the roots to 6 or 8 inches and plant the vine so the lowest bud is just above the ground. Press good soil firmly about the roots. Cut off all but one cane and prune it back to leave only two buds. Frequent and thorough cultivation is necessary. (See page 28.)

AGAWAM (Red)-CThe most widely grown of the Rogers Hybrids. Bunches are large. Berry is large, rich, sweet, and aromatic. Vine is vigorous and self-fertile, but does not yield well in some localities. Ripens after Concord and can be kept much longer, and improves in flavor. Seems to prefer clay soil. Of the red grapes, it is the easiest grown and most dependable. For home use and market. Keeps in storage till midwinter. Blooms rather late.

BRIGHTON* (Red)-A handsome high quality red grape; clusters and berries are large. Vigorous, productive, dependable, adaptable to various soils. Ripens before Concord. Deteriorates rapidly in quality after ripening. Blooms rather late.

CAMPBELL EARLY (Black)-Bunch and berry are large; high quality when mature, but colors before ripe and often marketed in unripe condition; good keeper and shipper. Vine is productive, hardy but not adapted to wide range of soils. Ripens about two weeks before Concord. Blooms midseason.

CONCORD (Black) - The most widely-planted grape. Superior in hardiness, productivity, and regularity in bearing and in ability to withstand disease and insects. Good size of bunch and berry. Very handsome in appearance. The fruit is sprightly and refreshing. It is the leader for making grape juice. No other grape has been able to compete with it on the market, as it can be produced so cheaply. Blooms midseason.

DELAWARE (Red) - The standard of quality; the best table grape. Unusually hardy; adapted to wide variation of soils and conditions, and usually bears abundantly. Ripens a few days earlier than Concord. Ships and keeps well and more immune to black rot than other commercial varieties. Its faults are: Small size of vine and berry, slow grower, and foliage susceptible to mildew, which can be controlled by spraying with Bordeaux mixture. It succeeds best in deep, rich, well-drained, warm soils, and should be planted more closely than most other varieties. It commands the highest prices and is valuable North and South for both home use and market. Blooms rather late.

DIAMOND (Green)--Seldom surpassed in quality and beauty. It is the hardiest. most productive and vigorous of the green grapes, although Niagara bears more heavily in most localities. A good keeper and shipper. It deserves a high place among the best for commercial and home vineyards; unfortunately often sold as Niagara. Medium size; green, with tinge of yellow, but less yellow than Niagara. Can be grown as widely as Concord. Blooms midseason,
MOORE EARLY (Purplish-Black)-The most widely planted early commercial grape. Ripens two weeks earlier than Concord. Fair to good in quality. It is best described as an early Concord. It should be planted on rich, welldrained, loose soil, but succeeds on rocky, hilly ground, where others fail. Blooms midseason.

NIAGARA (Green)-The most widely planted green grape. Larger bunches and berries than Concord, as good, or better in quality, but inferior to Diamond. Productive, vigorous, adaptable; not as hardy as Concord. Ripens about with Concord. Keeps fairly well. Flavor not at its best unless fully ripe. Blossoms midseason.

WORDEN (Black)-Much better quality, larger berries and bunches and handsomer than Concord and is equally healthy, hardy, vigorous, and productive, but often more particular as to soil. Its chief fault is a tendency to crack. Ripens a week to ten days earlier. It does not keep long, but is especially desirable for the home garden and for nearby markets.

"I had about 25 tons of grapes from your vines I set out four years ago. They are prouonnced the best flavor of any grape iu this valley."-W, Wetherell, San Juan County, New Mexico. REST BY COMPARISON

"Best stock (500 grape vines, 2 peach, 2 apricot) for the price we ever bonght and have bought from several nurseries."otto Flowers, Washington County, oklahoma.

\section{Proper Care Brings Great Rewards}

These Concord and Niagara grape vines bore fruit the second season. They were planted by our customer. Mr. Wm. Meyers of Brookfield, Mo., in the spring of 1922 and the picture was taken in Octoher. 10\%3.

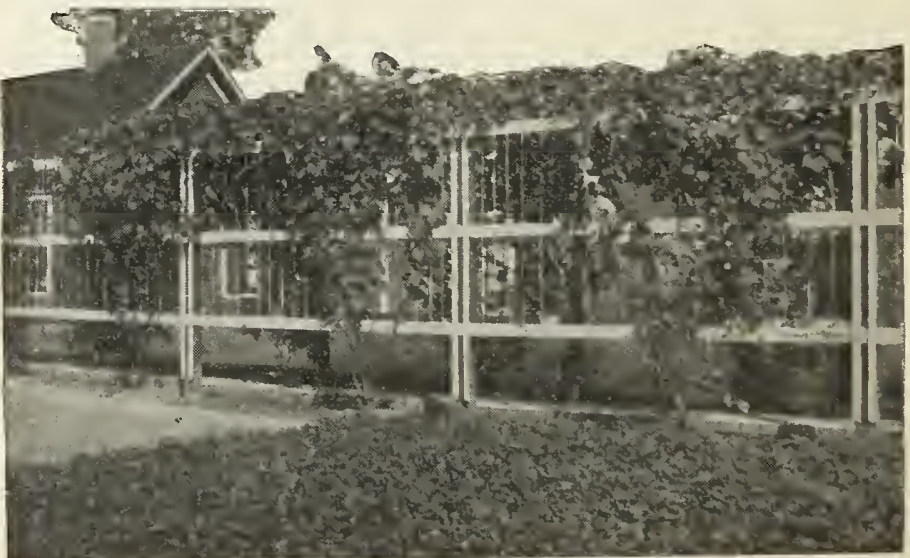




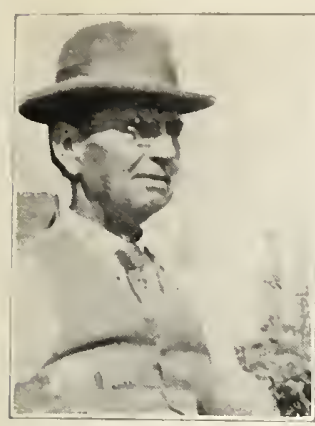

A Californi Aroud of picture.

\section{Let Us Help You to Make Fruit Profits Growing Fruit for Profit}

One of the most striking instances of profit from fruit growing is that of the Big Four Orchards at Nashville, Arkansas. They planted 250 acres of Neosho Nurseries peach trees in 1920 and the president, Mr. B. L. Thompson, wrote us April 16, 1927, as follows:

"It has paid the stockholders their money back that was put into it to start with and $45 \%$ besides."

No doubt you have read of many instances of good profit with other kinds of fruit also. We could tell you about plenty of them. But the question is, "How is it done?"

\section{APPLE ORCHARDS---Opportunities for Thinkers}

One man succeeds where another-with equally good opportunities-fails-management is the main factor.

There is a fine young orchard near Neosho of our trees, while across the road there is nothing left of an orchard planted at the same time. That was due to poor trees at the start.

Compare the average annual cash returns per acre over 5 years of these two Michigan orchards:

A. $\quad \$ 111.50$ - $\$ 151.25 \quad \$ 334.50$

Trees 13 to 20 yrs, old 21 to 35 yrs. old Over 35 yrs. old

B. $21.30 \quad \ldots \ldots . \quad 48.00$

These orchards are a short distance apart, contain the same varieties and the trees are about the same average age. The difference in results lies in management and location.

\section{Here Are The Factors That Govern Profits}

(1) A Good Site-That is a location which is not subject to severe spring frosts-ground that is higher than the adjacent land and has good air drainage. That means regularity of production. We can show you orchards in valleys and in pockets which never have any fruit, or so little as to amount to nothing.

(2) A Good Soil-This calls for fertility and depth. It means heavy yields and lower cost of production.

(3) Next in importance is production of a high percentage of Grade A fruit which commands the best price. That means size and freedom from blemishes. Size is determined by soil and good management. Blemishes are prevented by timely and thorough spraying and by careful handling.

(4) Selection of Varieties-

(A) Heavy yields are the first consideration. Shy bearers increase the cost of production.

(B) Select varieties that bear a large percentage of grade A fruit.

Part of Apple Display, Neosho Harvest Show. Nearly All the Gxhibitors Are Our Patrons

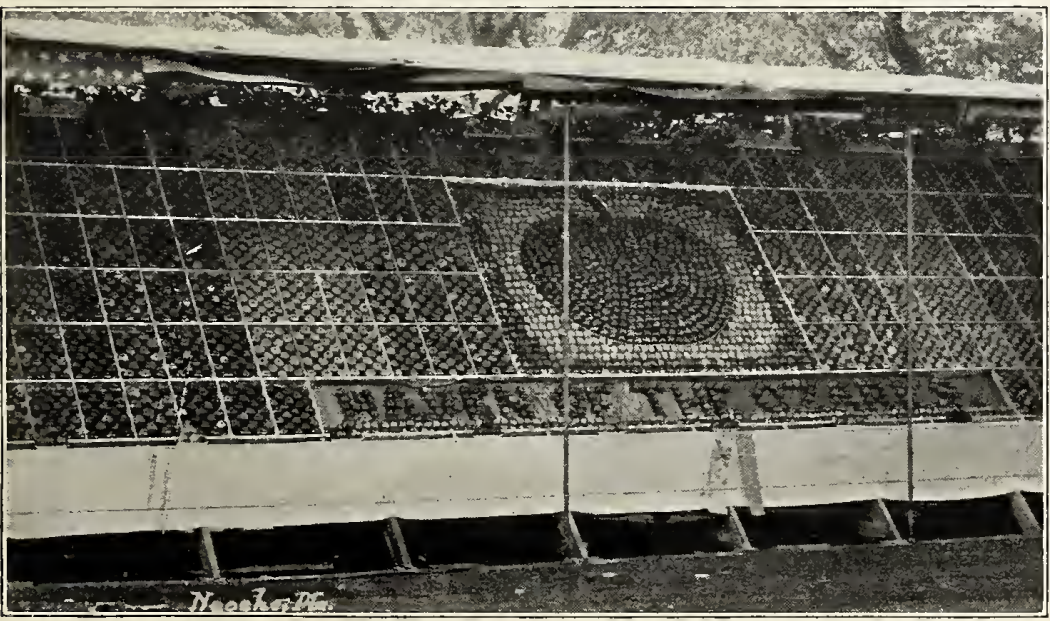

(C) Next in importance is the selection of varieties that command the best prices. The wholesaler and retailer will pay good prices for what he can readily sell. Usually quality varieties are preferred, but there are exceptions-early varieties like Yellow Transparent and Duchess which are used for cooking. Ben Davis, Black Ben, Champion and Gano have proved quite profitable for many growers, but such varieties do not stimulate the demand for apples and there are some better varieties which are usually more profitable in most districts.

(D) It should not be necessary to noint out that varieties must be adapted to one's climate-for instance northern varieties like R. I. Greening have not proved successful in the Ozarks of Missouri. It is certainly a big gamble to plant (except in a small way for testing) varieties whose production and behavior in one's own district are unknown. An orchardist south of Neosho lost 25 three-year-old trees of an untried variety from winter injury, while none of his other varieties were damaged.

(E) There is no perfect variety. All have some drawback such as susceptibility to blight, etc. The Grimes Golden is adapted to a wide range of climate, stands high in production and regularity of bearing, bears a good per cent of grade A fruit and brings good prices on most markets. But it has one bad fault-susceptibility to collar-rot which attacks the trunk near the ground. This trouble can be prevented by planting double-worked trees. (See page 7.)

(F) If you plan to ship to market, about four varieties is enough. For local market it is well to have some early and midseason varieties so as to supply the demand over a long season.

(G) If your varieties are ready to sell when there is the least competition from other fruits or from other growers, your sales will be easier and your prices higher. Neosho is in the heart of a big producing center of Strawberries, practically all Aroma, which ripens at a time when competition from other districts is least.

(5) Next comes the problem of arrangement. Some varieties are more or less sterile so it is wise to plant not more than four rows of one variety alternately with another for crosspollination. The set of fruit will be greatly improved by moving bees into the orchard, about one colony to the acre, avoiding the hazard of poisoning by putting the bees in the orchard between the pink spray and the calyx spray.

(6) Securing Nursery Stock-Since an orchard is a life time investment and the purchase price will be an insignificant item of cost by the time the trees come into profitable bearing, obviously it pays to plant only the best trees-trees that will thrive and produce profitable crops for many years.

(7) Proper Care includes planting, maintenance of soil fertility and moisture, timely and thorough spraying, pruning, etc.

(8) Information-See index page 48 for other data and other fruits, and other sources of in. formation. Tell us your problems. We will help you to solve them to the best of our ability. 
Neosho Products and Service Produce Growing Satisfaction

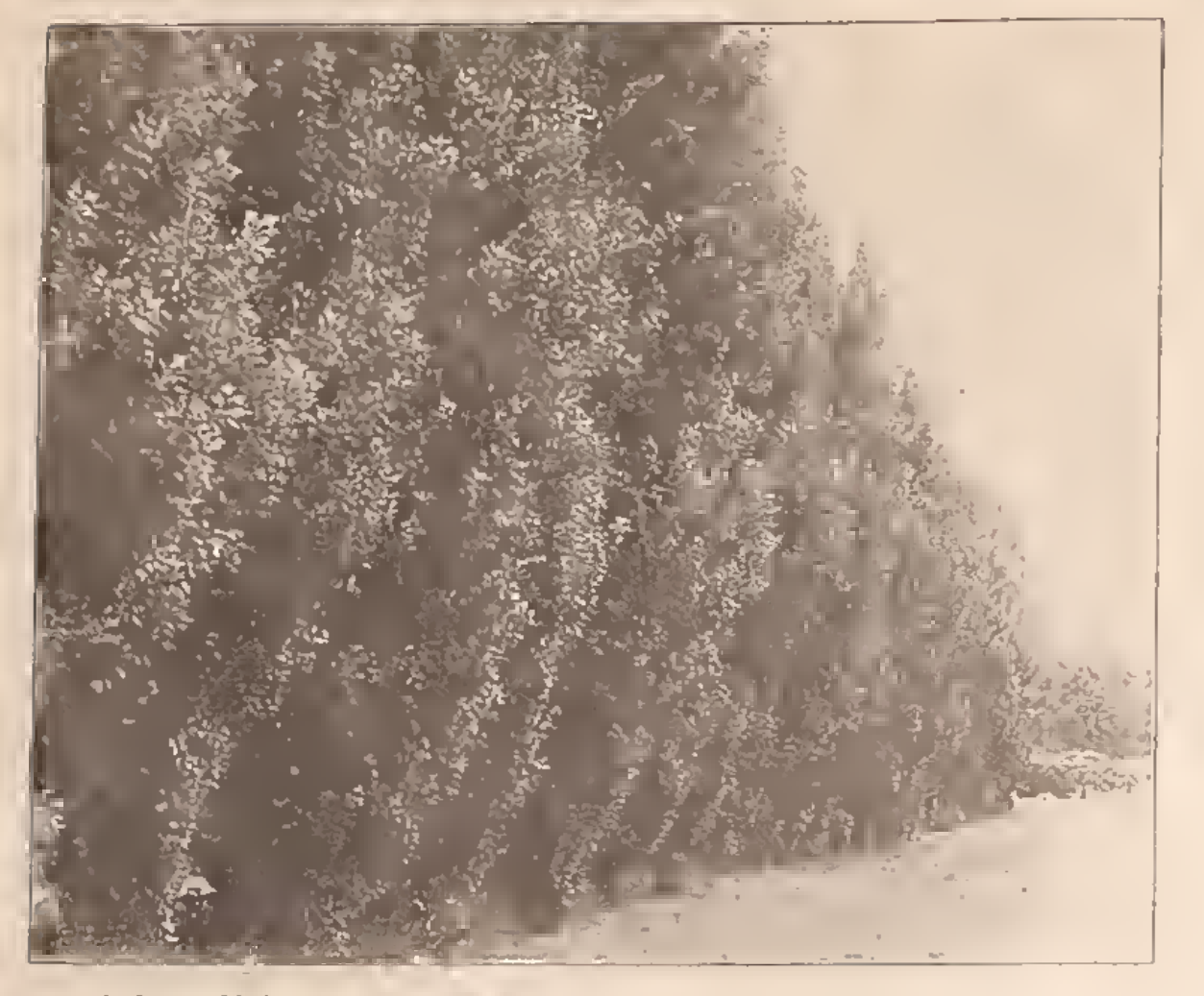

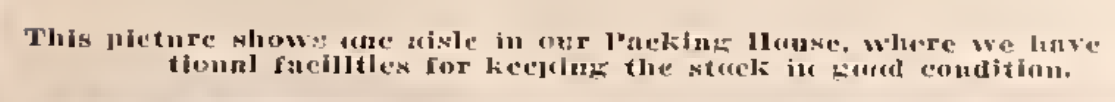

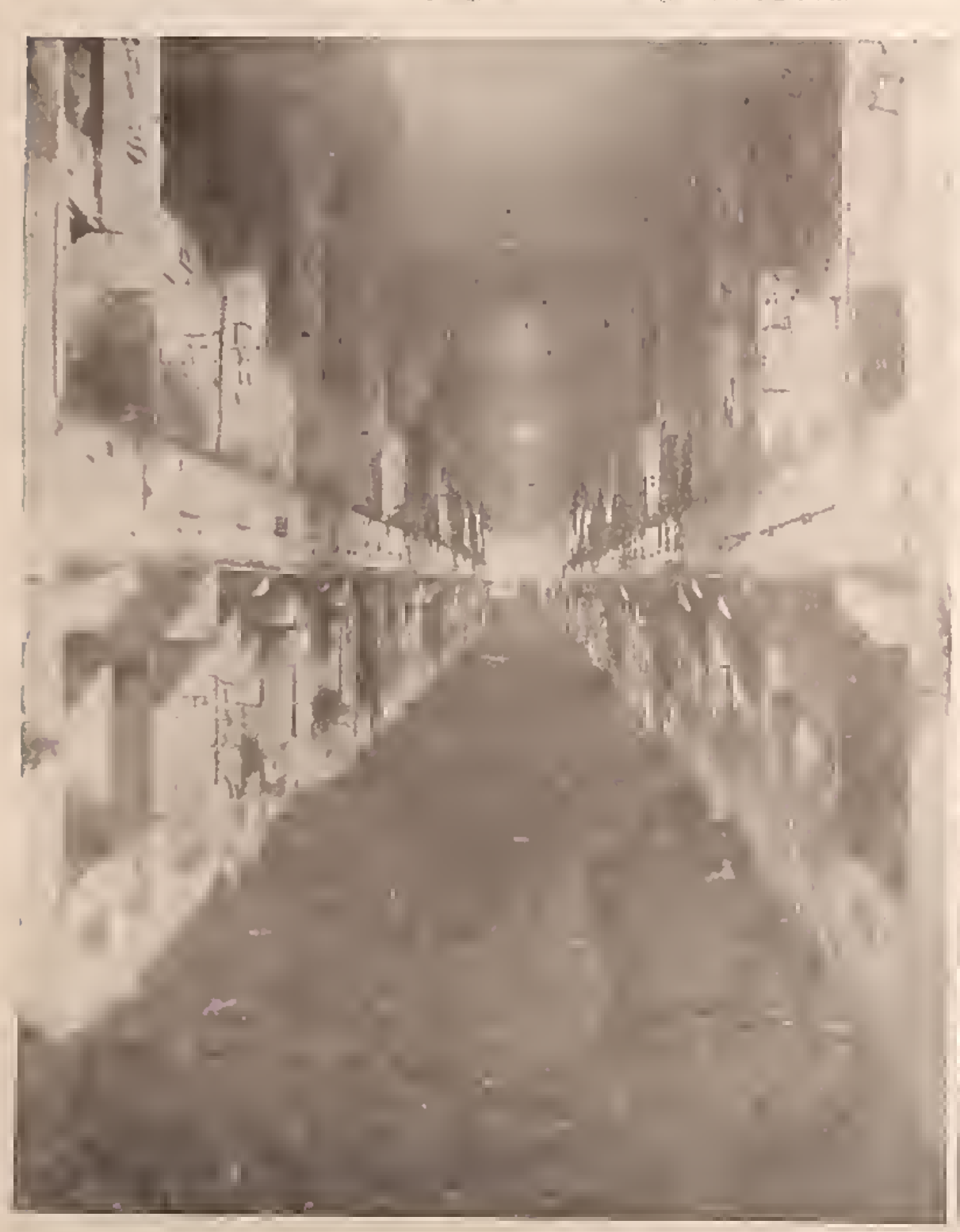

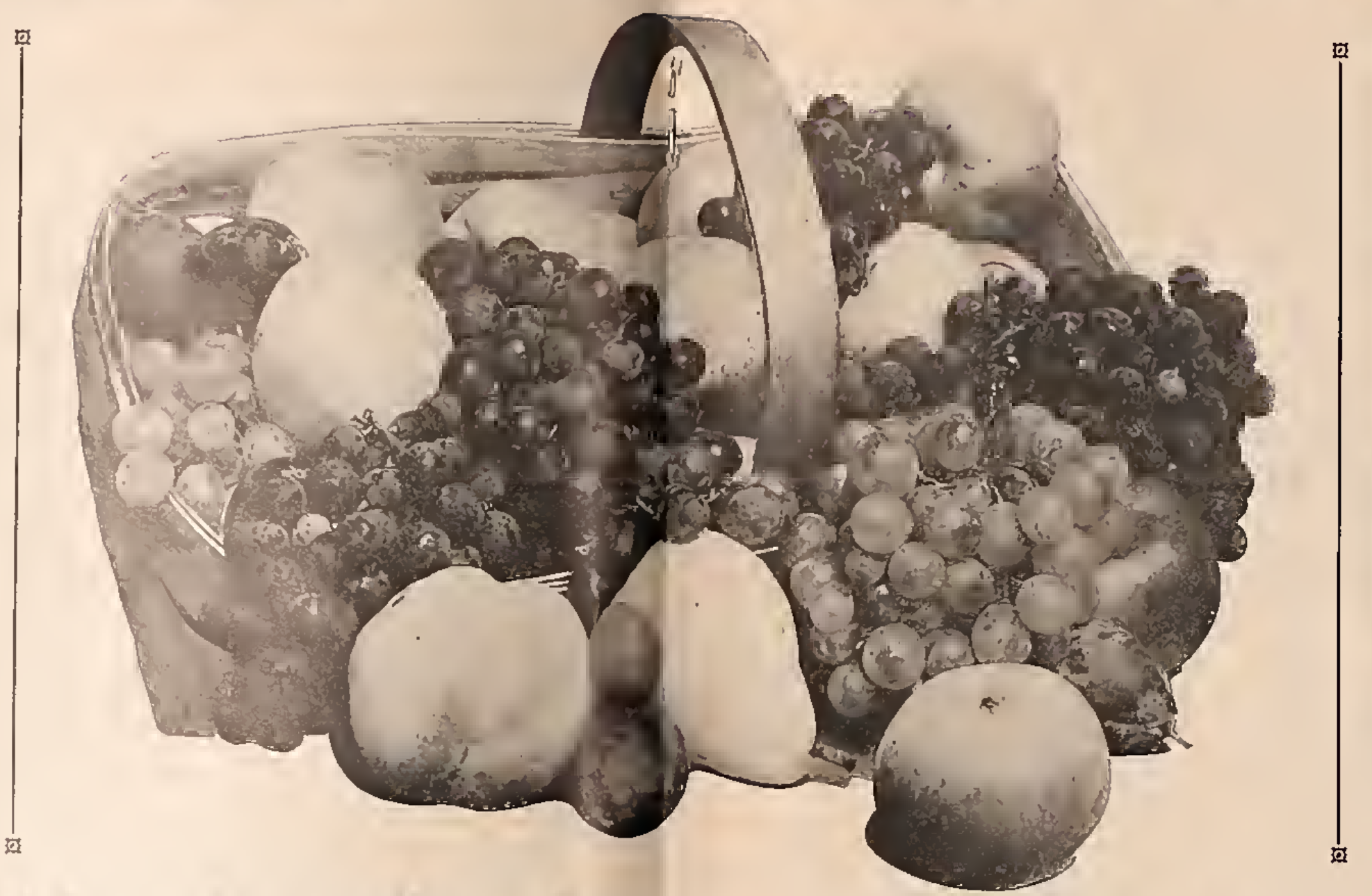

The Neosho Nurseries Company Neosho, Missouri

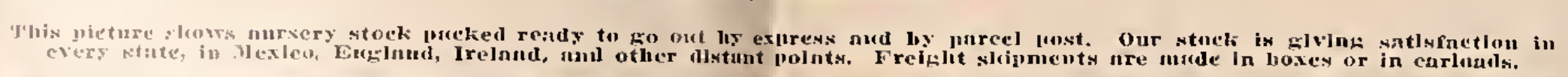

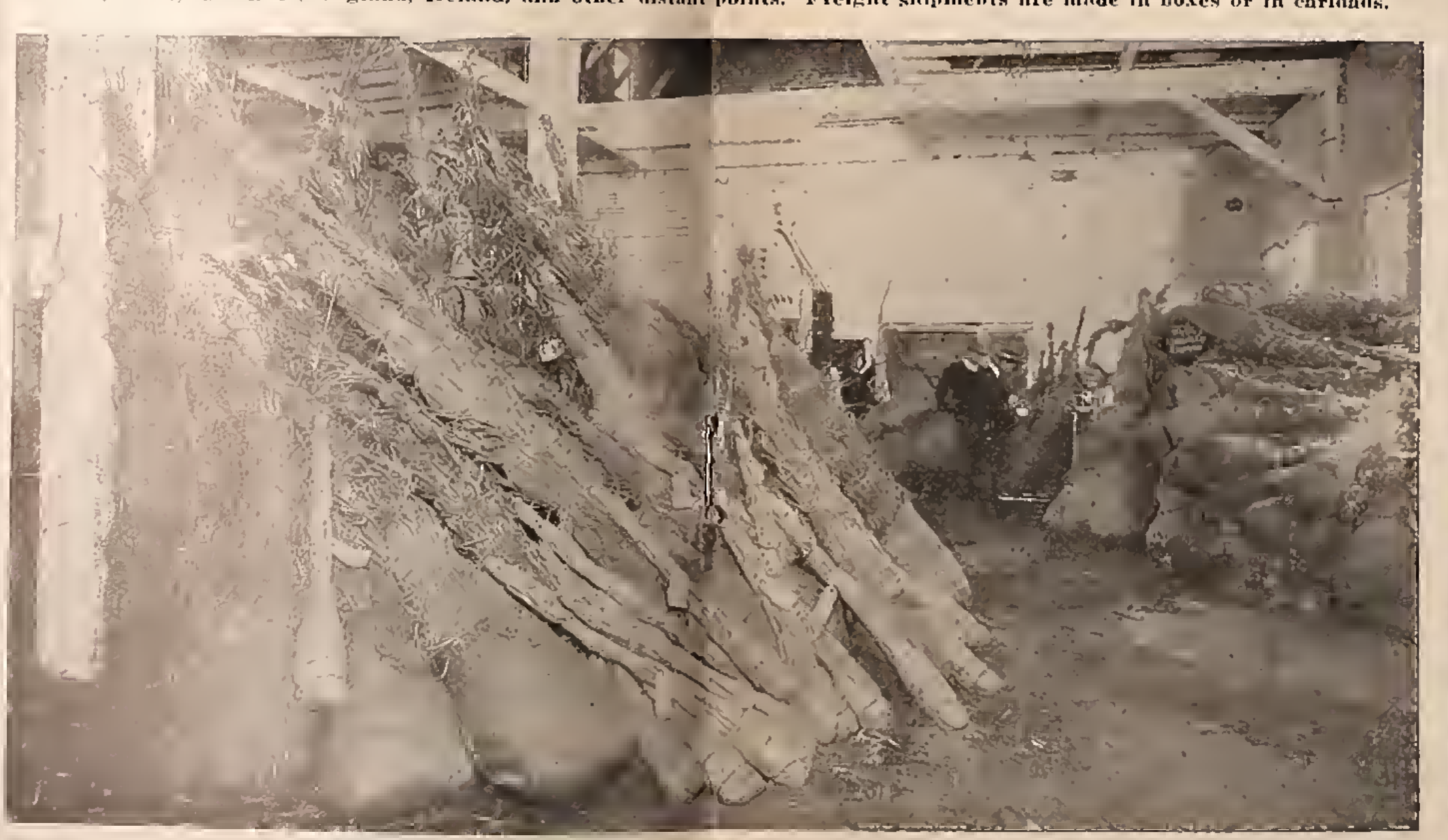

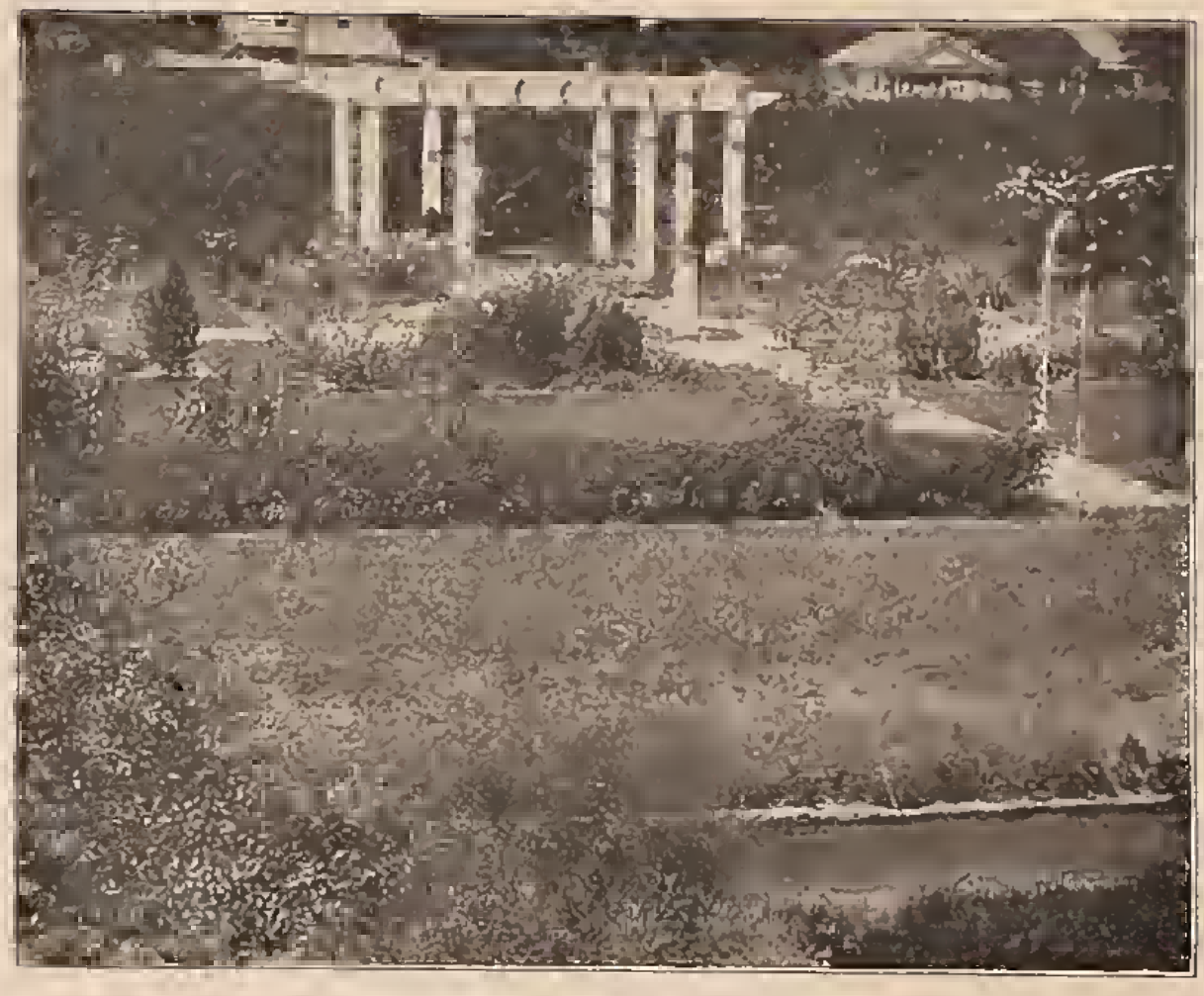

Another view of our Fornal Garden at Nenslat.
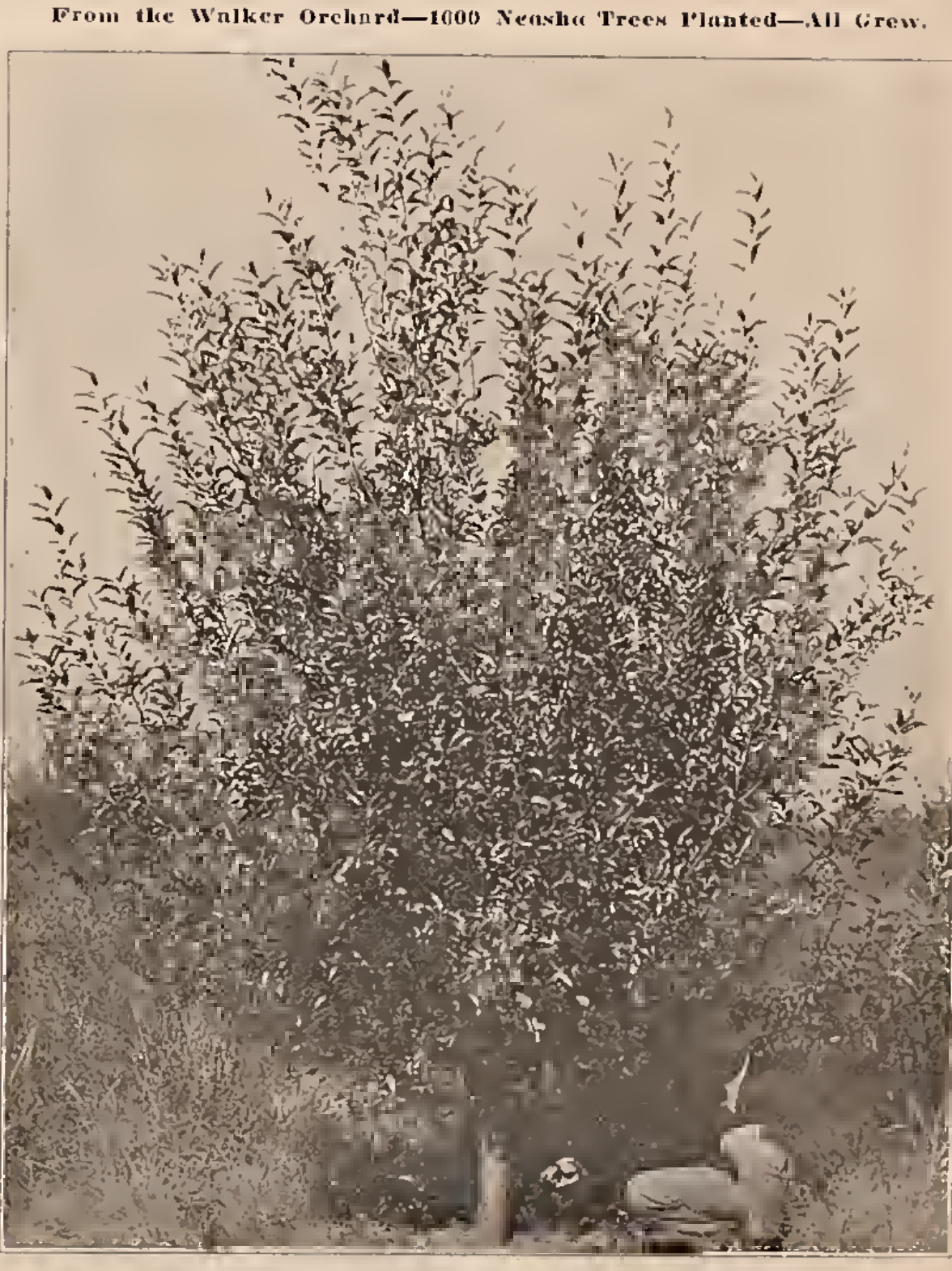


\section{Pruning}

Pruning is the removal from a plant of the part or parts which are undesirable or superfluous, and the object is to improve results or to make them more certain. Nature's purpose is the production of a large number of seed, but the gardener wants quality fruit.

The first thing to develop is a good framework to carry a load of fruit and to make it easiest to spray and harvest. One must picture in advance what one wants to accomplish.

HOW TO PRUNE-Make all cuts smooth, close to the trunk or branch, or close to a bud.

TREATING WOUNDS-The general practice has been to paint wounds over two inches in diameter with a paint of pure white lead and pure linseed oil. Some use creosote, a very thin coating, over the center, but this must not be allowed to touch the young wood or young bark. Some recommend Sodium Silicate ("water glass").

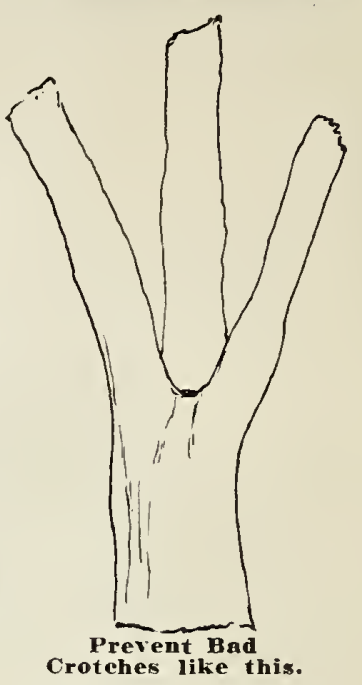

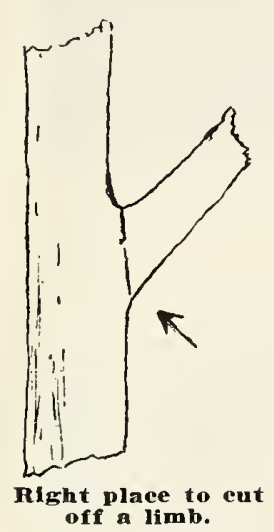

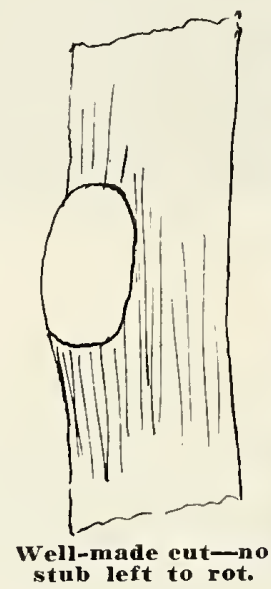

off a limb.

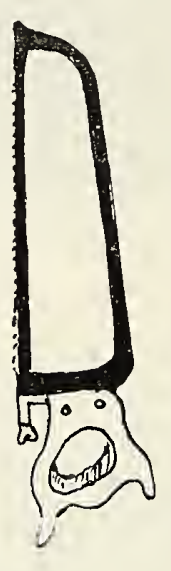

\section{Apple Pruning}

The apple bears on "spurs" and this fruit-bearing wood must be encouraged and preserved.

The best form or shape is the Modified Leader Type, which has more and better fruiting wood, is likely to bear younger, avoids weak crotches and has well-spaced branches and a low, spreading top. The training to this type is as follows:

If the tree you plant is a "whip" (with no side branches), the only pruning is to cut off the top 28 to 30 inches from the ground. This is to restore the balance between the top and the root system since a part of the roots may have been lost in digging and the small fibrous roots have to form again from the larger roots.

Assuming that a whip has been planted, during the first summer pick out the branches you want to keep and pinch back the others. This will cause the selected branches to make a better growth.

At the end of the first growing season, before growth starts in the spring it will be necessary to cut off close to the trunk all the branches except those selected to form the framework of your

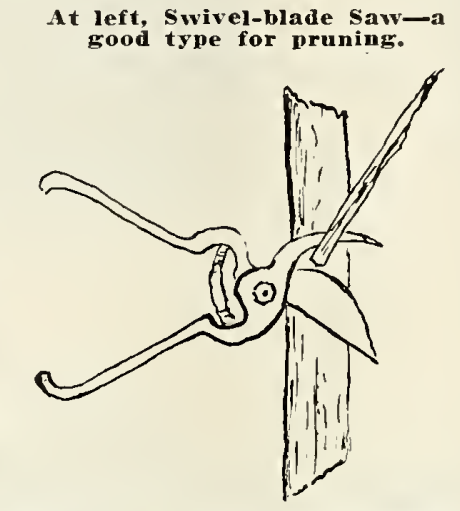

Riglit way to use Pruning Shears -the cutting blade close to part that is left.
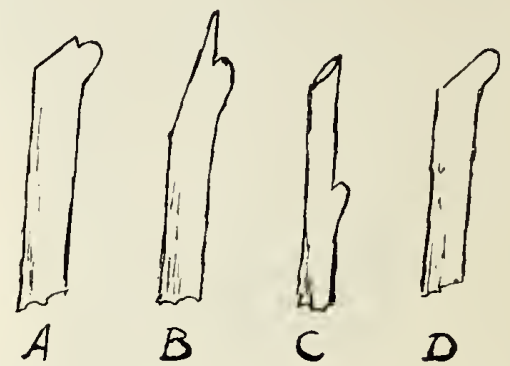

A-Right way to eut twige.

B-Too long a slant.

C-Too long a stub.

D-Too close to bud. tree. Then shorten the leader a little and also any side branches that are too long or unequal in length. See Fig. 1 and 2 .

If you plant a well-branched tree (some varieties of one-year budded apple are well-branched), it will be necessary to remove all but 3 to 5 side branches, selecting those well distributed about the trunk and spaced 6 to 8 inches apart. Also leave one branch growing from the top which will be the leader. This should be shortened a little and the side branches selected also cut back one-third to one-half their length.

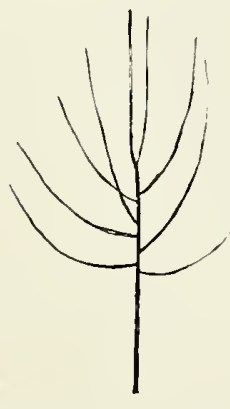

(Fig. 1) At end of first season's growth (if a "whip" wne planted), and before pruning.

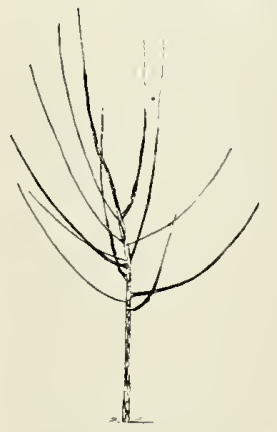

(Fig. 2) Same tree as in Fig. 1, but after pruning. If you could look down on the tree you would see that the three side branches come out on different sides of the trunk.
(Fig. 3) This shows the tree after two seasons' growth and before the second pruning.

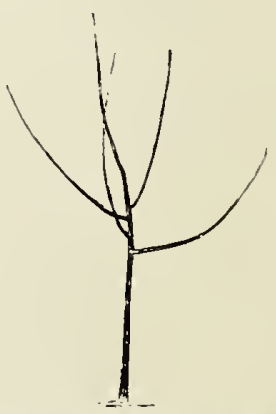

(Fig. 4) The tree in Fig. s after second pruning. Many shoots have been removed. and the lender as well a: the branches have been shortened. 


\section{APPLE PRUNING (See Preceding Page)}

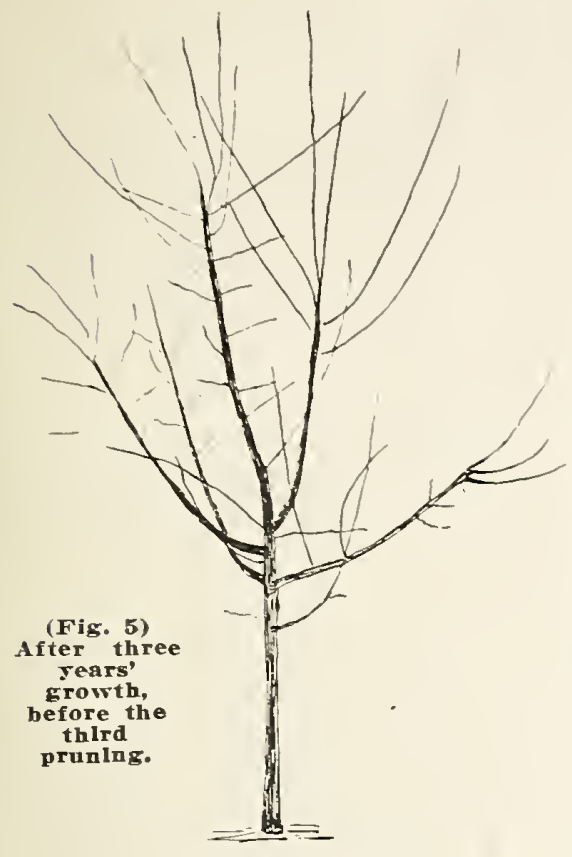

Tlie fourth season two or three more side branches should be selected from the central leader and these may be headed back if they threaten to over shadow the lower limbs. When you about six, the leader should be cut off just above the top side branch.

From then on pruning should be as little as is necessary for the proper spacing of framework branches and keeping them in proper proportion. It will be confined to removal of branches or confined to removal of branches or proportion to other branches.

proportion to other branches. the thinnest and the lowest the densest, to help maintain good wood all over the tree. This calls for checking of the stronger branches and giving the lower limbs an equal chance to grow and fruit well. If, in heading back, cuts are made to relatively good sized lateral branches, there will be less suckering and quicker healing than if cuts are made back to smaller laterals. However, rertilization cure the desired growth throughout the entire tree.

\section{Pruning Pear}

The pear also bears fruit like the apple, on "spurs," and is pruned much the same. Most varieties, however, tend to grow in an upright form and are usually headed lower. Light pruning is outside buds whenever possible. Heavy pruning induces young growth, which is more susceptible to blight.

\section{Pruning Dwarf Pear}

Dwarf Pears are usually trained to pyramid form, which calls for a central trunk with side branches, the longest nearest the ground. The longest branches, called leaders, are severely spring.

This ought to result in growth of side shoots, which should be pinched back during June and July to develop fruit buds. This is done when the shoots have about six leaves, all but three of Which are removed. When these shoot send out other shoots the latter should as three are formed. This pruning is done every year. i main branch leader may be allowed to rebranch leader may be allow th rebranch and these should have the shoots pinched back in the

\section{Pruning Apricot}

Apricot bears fruit on last season's growth and also on fruit spur. Pruning is similar to that of the peach. The old wood needs to be thinned out from time to time and the tops will properly pruned every season.

\section{Pruning Cherry}

\section{Pruning Plum}

Plum bears partly on spurs and partly on last season's growth.

Some growers at planting time prune the same as with peach; others, when setting branched one or two-year olds, select three to five branches, cut them back one-third to one-half and head back the leader proportionally.

Varieties differ widely in habits of growth. The Japanese varieties grow more like the peach and are pruned much the same. The Burbank is a rank sprawling grower and needs more heading back.

As a rule it is better to let the trees taken soliting form. should be remover interfering limbs and thinning out and back should be sideration of the way the tree grows. left, selecting those that are well spaced and on different sides of the trunk.

From then on little pruning is required. It may be necessary to remove some branches that cross, or some that grow back into the trunk, or some that are too close, or to thin out the top before the branches become so thick that they shade and kill out the lower wood. It is desirable to encourage fruiting in the lower part of the tree. Heavy pruning can be avoided by doing a little every year avoided
Hear in Mind-as trees grow older, two puralel branches even 12 to 18 inches apart will crowd each other and one branches to be removed. Also two inches apart near the trunk of the tree. will in time crowd each other and one should be avoided, otherwise they should should be avoided, otherwise the
be remedied as early as possible.

Cutting a branch heavily lessens total growth of that part.

Pruning a branch lightly increases the growth of that part.

Two branches growing out from the one back more than the other, which in time will become the leader or main branch, while the shorter will become a branch.

"Heading back" is cutting off a part of, or reducing the lengtl of, a shoot or oranch.

"Thinning out" means the removal of the entire shoot or branch.

\section{Pruning Peach}

The fruit is borne on last year's wood. After the tree is planted, cut off the top 18 to 24 inches above the ground and cut off any side branches about an inch from

During the first season when the growth is four to six inches long, choose sides of the trunk and well spaced. Assuming that you select three branches, suming that you select three branches, above the ground and the lowest branch about a foot. Every three or four weeks tip ends of all the other branches. If these are very numerous, some of them may be cut off close to the trunk. If this pinching is don

During the second summer select two or three shoots growing outward, not upright, on the main branches and pinch back the others.

During the third summer, less pinching back is required and during the sary. All that is needed can be done in the winter pruning.

The result should be a tree low-headed, spreading, with a well-balanced framework that will produce large crops of
quality fruit and come into bearing quality

This style of pruning causes growth at many different points rather than much growth at a few points near the cuts. Severe pruning only seems to produce better gro the expense of the lower parts of the tree and the total growth of the tree is diminished.

As the trees get older it will be necessary to prune the tops more heavily in late spring (some growers delay this pruning until the trees are in full lower down in the tree begins to die out lower down in the tree begins to die out it indicates that the centers and top are not open enough. If these twigs and velop a long growth it shows the top and centers are too open.

If you have old trees that seem to need heavy pruning, cut back moderately, say three to five feet. making a smooth cut
to a good sized limb extending outward. to a good sized limb extending outward. new growth is one or two feet long, remove the strong sprouts that pus
where new limbs are not desired.

\section{Pruning Quince}

The fruit is borne at the tips of shoots that grow out the same season from last year's wood. They should be headed low, trunk up to the lowest branch.

Pruning should aim to keep the top open and well spread out by removing superfuous interior branches and oy desired. 


\section{GRAPE PRUNING}

The fruit is borne on shoots that put out from last year's growth. When the plants are set, cut off the tops so as to leave two or three good buds, and shorten the roots to about eight inches. The first summer the vines are allowed to grow at will.
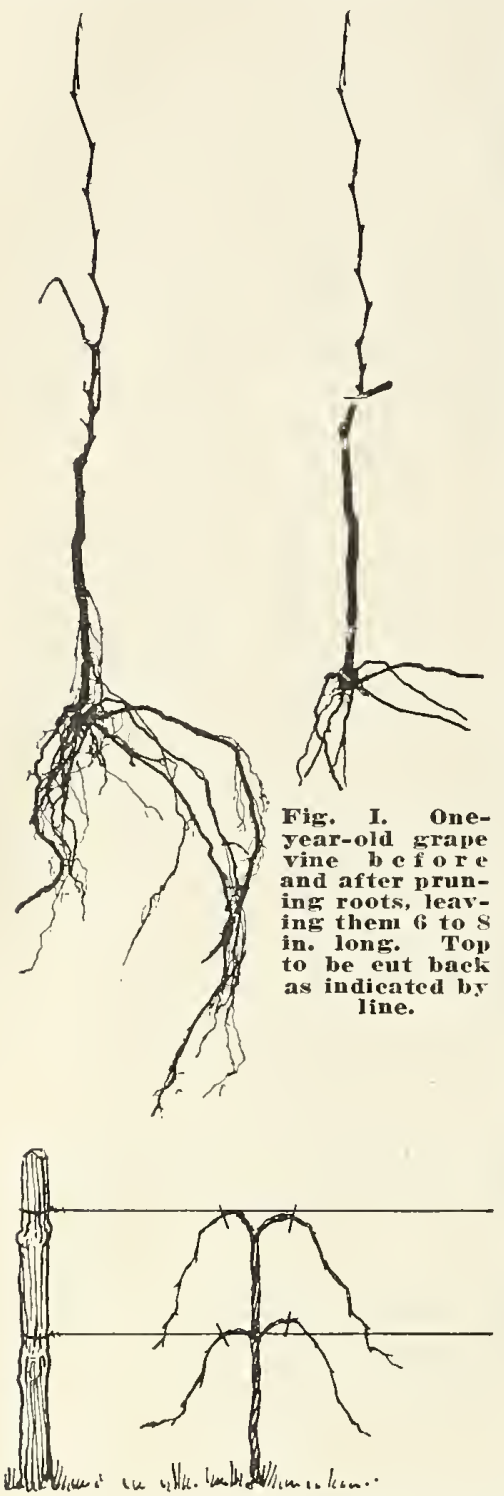

Fig. II. End of second summer. During that summer the top of the cane was pinched off and also all where canes are pruned the following vinter.
The following spring before growth starts select the most vigorous cane, cut it back, leaving two good buds and remove entirely all the other canes. If a strong growth has been made the cane selected may be cut back only to the height of two and one-
half to three feet. It will then be necessary to decide on a definite system of training.

The most popular is the four-arm Kniffin system. This calls for a trellis of two wires. Posts about six to seven and one-half feet tall are set 18 to
24 inches deep and 10 feet apart. The end posts 24 inches deep and 10 feet apart. The end posts is stretched tight on the posts, the lowest wire two and one-half to three feet from the ground and the other wire two to two and one-half feet
higher.

The second summer when the new shoots are about a foot long, select the straightest and strongest and cut off the other shoot or shoots. This selected shoot or cane should be tied to the wire, or a stake if the trellis has not already been put up. When this cane reaches the top wire it should be tied to that wire and growth above that wire pinched or cut off. This will force out side branches, which should be removed as soon as they

The following spring before growth starts, choose two side branches or laterals to run along each of the two wires. Shorten these back so as to leave 10 to 12 buds to each lateral and cut off the other laterals to one bud.

The third year, remove in summer the shoots that come out on the trunk between the wires, between the lowest wire and the ground, and any that come up from the roots. In the spring select four laterals, two for each wire, shorten them other laterals to one bud.

\section{Pruning Bearing Vines, Kniffin System}

Save four strong canes, one on each side of the trunk for each of the two wires.

Cut these to about 3 feet long for the top wire and a little shorter for the lower wire. Make cuts about an inch beyond the last bud.

Cut off other canes, except that two as near the wires as possible should be cut back to two buds to make fruit bearing wood for the next season.

Winter pruning may be done any time after the leaves fall until growth starts in the spring, but with small plantings it is better to wait until just before growth starts. In any case do not prune when vines are fro.

The amount of fruiting wood to leave when pruning varies with the vigor of the vine. An average Concord vine can produce about 15 pounds and still grow good fruiting wood for the next should be left.

\section{RABBIT AND MICE PROTECTION}

The best way is to put around the trunk a roll of galvanized wire cloth of one-fourth inch mesh. Many use paper but remove it in late spring. Some have found it effective to paint the trunks with Lime Sulphur and Arsenate of Lead or White Lead and Linseed oil.

Mice injury can be prevented by keeping any weeds or grass away from the trunk or by wire protectors which should be pushed into the ground a couple of inches.

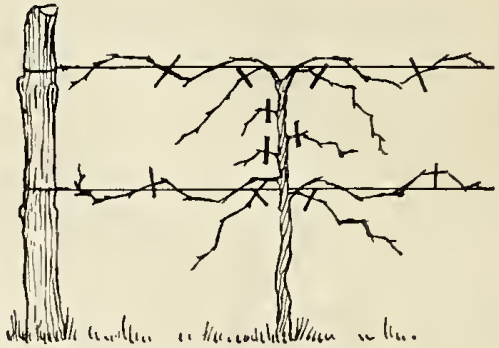

Fig. III. Shows growth during third season. Lines show praning the winter following.

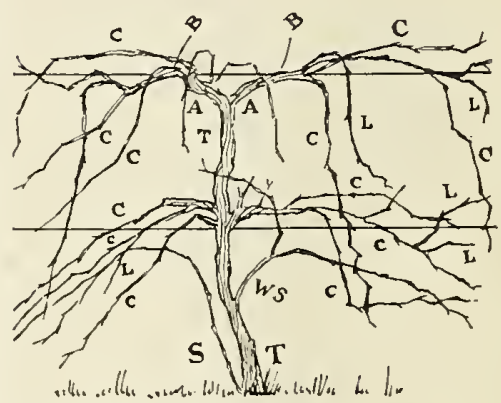

Fig. IV. Mature Vine.

\section{T-Trunk. \\ Sprouts. \\ S-Suckers. \\ A-Arms.}

L-Laterals which are secondary shoots of a eane.

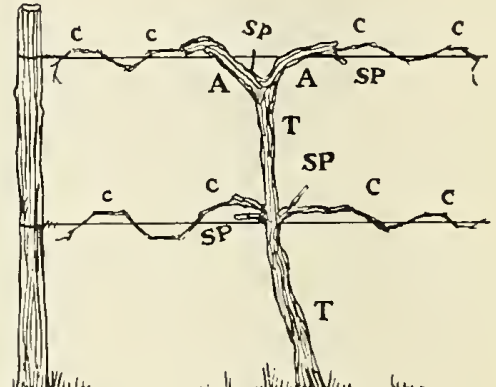

Fig. V. Iature Vine Pruned. T-Trunk.

A-Arms. SP-Spurs from which canes vill grow for fruit the next year.

\section{INTERCROPS}

\section{WHY TREES FAIL TO BEAR}

The blossoms of some varieties are more or less self-sterile, that is, the pollen of the variety will not fertilize its own blossoms. Home orchards usually consist of several varieties of the same kind and this difficulty is not often
present. In commercial planting it is present. In commercial planting it is wise to plant say four rows of one variety, alternately with four rows of another. That is the best plan even with
self-fertile varieties like Grimes and

Lack of pollination, and therefore a crop failure, may be due to cold, wet weather at blossoming tim

Failure to bear may also be due to the condition of the trees. If the tree makes a small amount of new growth, the fruiting wood will also be weak. This condition may be remedied by cultivacon fertilizers containing a large percentage f trees may be making too vigorous trees may be making too vigorous producing wood. In such cases less producing wood. In such cases less pruning, less cultivation or less fertilization, or even planting to grass wil pruning is also practiced by some experienced orchardists.

Fruit buds may also be killed by extreme winters, or may be injured by late spring frosts. If the trees are kept in a healthy condition the buds will be hardier.
Fruit trees do not the first few years and various crops are sometimes used to secure earlier returns from the land. Annual crops such as early beets, turnips, radishes, peas and beans are good, but late vegetables should be avoided since they require late cultivation, which prevents the trees from maturing properly before cold weather. Currants, gooseberries, strawberries and raspberries have also produced good results. With strawberries there is danger that the trees will not receive proper cultivation after the first season.

Grain crops should never be used.

A space 6 to $8 \mathrm{ft}$. should be left unplanted along each row of trees and increased in width each year.

of course, if intercrops are grown more liberal fertilization must be given. 


\section{Planting Plans}

The Square Plan is the simplest and most commonly used, and under it the operations of cultivation, spraying and harvesting are conveniently done.

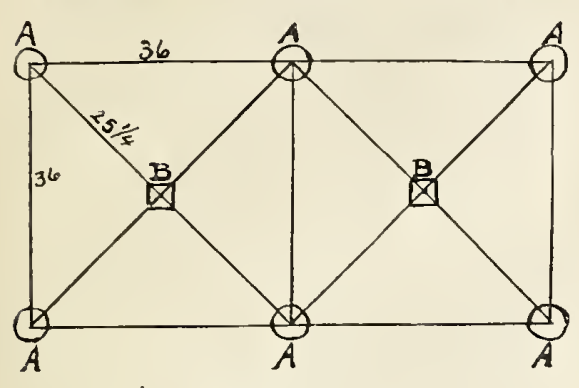

Square Plan

The permanent apple trees are set at $A$ and young-bearing smaller growing apple trees at $\mathbf{B}$.

\section{Fillers}

Fillers are trees set between apple trees, and may be cherry or peach or young-bearing, smaller growing apple trees like Yellow Transparent, Duchess of Oldenburg, Wagener, Wealthy, King David. Cherry and peach are not as desirable as apple because the methods of handling, especially spraying, are different.

Of course, filler trees must be removed when they begin to crowd the permanent trees. There should be no more hesitation about cutting out the fillers than in removal of a limb at pruning time.

There are various ways of setting fillers as suggested under Planting Plans.

\section{Cover Crops}

Any crop grown in the orchard the first two years should be one that requires frequent cultivation, such as small fruits, potatoes, melons, tomatoes, etc. With the last cultivation in midsummer it is a good plan to sow a cover crop. These aid in ripening the trees for winter, prevent washing and leachfor winter, prevent washing and leachspring add humus and fertility to the soil, hold snow and rain in winter and early spring and protect the roots from injury from freezing and thawing.

The legumes make the best cover crops, as they gather nitrogen from the air and deposit it in the soil, the tops rot and supply humus, and the roots decay and improve the soil. Cowpeas are the best for Southern states, south of New York City and Omaha. It is a hot weather plant, thrives remarkably well weather plant, thrives remarkably well on light solls, and in dry seasons. $11 / 2$ to 2 bushels is the usual quantity of seed used per acre and is sown broadcast
or in drills. Soy beans, preferably early maturing varieties, are often used in Northern states. It is a good plan to sow them early enough so they can be cultivated the last one or two times the trees would be cultivated. Sow $11 / 2$ to 2 bushels per acre.

Vetches are very good; hairy or winter vetch, 1 bushel to the acre, thrives well at low temperatures, is adapted to heavy soil but also does well on lighter soils that have been carefully prepared.

Buckwheat is one of the best nonleguminous cover crops used chiefly in northern and northeastern states. It grows rapidly in late summer, on poor soils, and has a pulverizing influence on the soil but adds very little vegetable matter to the soil. It is best to delay sowing buckwheat until August ist or later, about 1 bushel to the acre. Rye is later, about 1 bushel to the acre. Rye is where other crops fail. A good growth of weeds is better than no cover at all.

Constant tillage year after year exhausts the humus in the soil. This must hausts the humus in the soil. This must
be replaced by cover crops or manure.

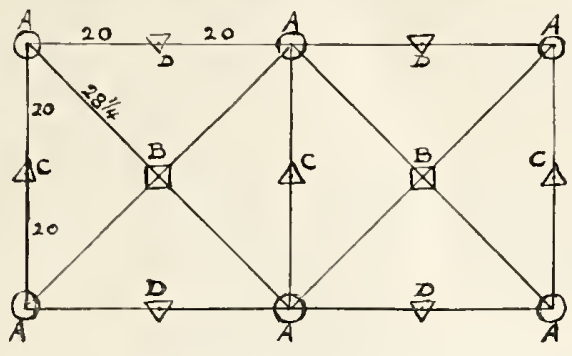

Square Plan

The permanent apple trees are set at $A$ and filler trees at B, C and D. Those at $\mathrm{C}$ will need to be removed earliest, then those at $D$ and lastly those at $B$.

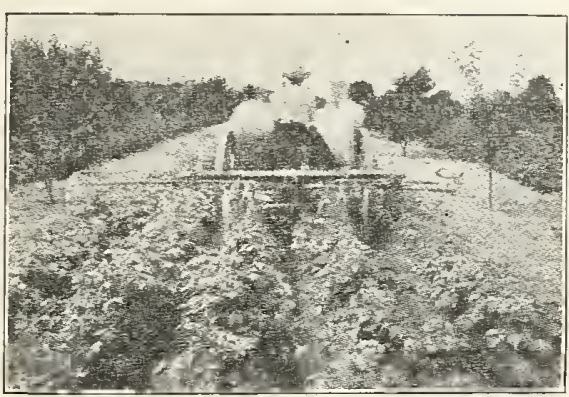

Make the land between the young trees pay dividends.

\section{Fertilizers}

If the growth is poor and the leaves small and yellowish, plant food is needed. Barnyard manure is the best allround fertilizer and also supplies humus. eral fertilizers may be applied at any time. For quick results nitrogen in the form of Nitrate of Soda or Sulphate of form of Nitrate of Soda or sulphate of Ammonia is used early in the spring when the buds show green. The amount required varies with the age, size and condition of the tree, 5 or 6 oz. of Nitrate
of Soda for one-year-olds, up to 4 to 6 of Soda for one-year-olds, up to 4 to 6 lbs. for old trees. Bear in mind that the feeding roots are not close to the trunk of the tree, but extend out beyond the
spread of the branches. Sulphate of spread of the branches. Sulphate of Ammonia contains more nitrogen and should be used in smaller quantities than
Nitrate of Soda, about 25 per cent less.

\section{Soil Management for Apple}

In the sod-muleh system, all grass is cut and left where it falls or is gathered and piled around the trees. It is the most successful method on slopes so steep that serious soil washing would result if the land were cultivated. It and cherry.

Under the nulch system, sufficient straw or hay is placed around the trees from the trunks out to the ends of the branches to keep all growth down. It is claimed that in severe climates winter injury is likely to result with this

The tillage cover-crop system is doubt less the most satisfactory. The ground is kept cultivated during the first part a crop that remains on the ground all winter and is turned under in the spring. Advantages claimed for clean cultivation are: The yields are higher; the fruit is larger and matures later; the trees grow larger, having larger trunks and twigs; the foliage is better, a richer darker green; that the trees have more vitality, resulting in regular crops.

The advantages claimed for sod culture are: It is less expensive; the fruit keeps longer; the fruit is more highly
colored; there is less washing on hill- sides; the ground is in bettcr shape for spraying: windralls are in better condition ( $w$ hich is of course more important with early varieties).

In any case, constant tillage without cover crops exhausts the humus in the

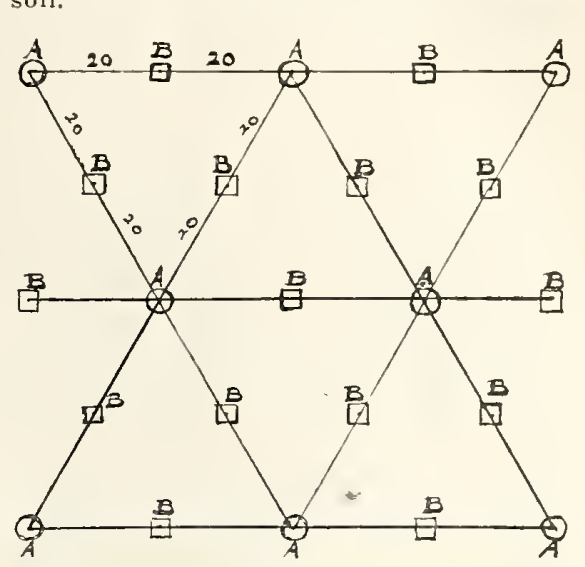

Triangular or Hexagonal Plan

Permanent apple trees are set at A, flller trees at B. The Triangular or Hexagonal plan uses more of the land and permits cultivation in three directions. The trees are set at equal distances from each other in all directions, and 15 acre than by the Square Plan.

\section{Sources of Information}

Each individual must solve his own problems in growing fruit and ornamental plants, but will, of course, deothers.

Information may be secured from the U. S. Department of Agriculture at your Congressman. And also from your State Experiment Station and Agricultural College.

Here are the addresses of the State Agricultural Colleges and Experiment Stations:

ALABAMA-Auburn.

ARIZONA-Tueson

ARKANSAS-Fayetteville.

CALIFORNIA-Berkeley.

COLORADO-Fort Collins.

DELA WARE-Newark.

FLORIDA-Gainesville.

IDAHO-Moscow.

ILLINOIS-Urbana.

INDIANA-La -La

KANSAS-Manhattan.

KENTUCK Y - Lexington.

LOUISIANA-Baton Rouge.

MAINE-Orono.

MARYLAND-College Park.

MICHIGAN-East Lansing.
MINNESOTA-University Farm, St. Paul.

MISSISSIPPI-Agricultural College. Grove.

MONTANA-Bozeman.

NEBRASKA-Lincoln.

NEVADA-Reno.

NEW HAMPSHIRE-Durham.

NEW MEXICO-State College.

NEW YORK-Geneva.

NORTH DAKOTA-Agricultural College. OHIO-WOOSter.

OKLAHOMA-Stillwater.

OREGON-Corvallis.

PENNSYLVANIA-State College.

RHODE ISLAND-Kingston.

SOUTH CAROLINA-Clemson

TENNESSEE-Knoxville.

UTAH-Logan.

UTAH-Logan.

VERMONT-Burlington.

WASHINGTON-Pullman.

WEST VIRGINIA-Morganstown

WISCONSIN-Lardison. 


\section{Control of Insects and Disease}

Fating Inseets-Eating Insects are controlled by a stomach poison. Arsenate of lead, powdered form, $1 \frac{1 / 2}{2}$ los. to 50 tablespoon to 1 gallon of water.

Sucking Inseets-Sucking Insects are controlled by a contact body poison (nicotine sulphate or miscible oils). For
soft bodied sucking insects, nicotine sulphate is used, $1 / 2$ pint to 50 gallons of water and 2 lbs. of soap. For small of soapy water.

Hard shell scale types of sucking insects are controlled by spraying with a strong mixture of lime sulphur

Fungous Diseases, such as apple scab, blotch, bitter-rot, cherry leaf spot and peach and plum brown-rot are controlled by either lime sulphur or Bordeaux
mixture. Use summer strength so as not to injure fruit or foliage.

\section{SPRAY MATEIRALS}

Lime Sulphur, a commercial preparation, can be secured in either liquid or Dormant strength, 1 pint to one gallon Dormant strength, pint to one gallon summer strength, 1 gallon to 33 gallons water, 1-33.

Self-boiled Lime Sulphur is prepared y putting 8 libs. of fresh stone lime in a barrel and nearly covering it with water. When the lime begins to slake, add 8 lbs. of powdered Sulphur which has been previously sifted to remove all
lumps. Stir this mixture constantly, lumps. Stir this mixture constantly, adding more water as needed until a thin paste is secured. Then add immediStrain the mixture thoroughly.

Bordeaux Mixture is used in differen strengths. $4-4-50$ is considered standard strength and indicates 4 lbs. copper sulphate, 4 los, unslacked lime to 50 gallons of water. Prepare mixture by dissolving 4 lbs, of copper sulphate in one vessel, slacking 4 lbs. of lime in another, pour together, stir well and add enough water to make 50 gallons preparations can be purchased.

Heavy Engine oils are being used of late years in dormant spraying for con trol of scale. Write to U. S. Dept. of for directions. (See page 29.)

Spray Equipment-The size of the spray outfit depends on the work to be accomplished. In general for shrubs and small garden work a 3 gallon compressed-air tank will be sufficient. For large gardens and home orchards, a barrel sprayer. For commercial orchards, you in touch with reliable manufacturers of spray outfits.
CONTROL OF BORERS

These pests of apple and peach trees must be killed by a wire thrust into their tunnels, disclosed by removing a few inches of dirt around the base of the tree. Go over your trees in April or Aay and in late August or september. After cutting out the borers mound up high.

The Flat-head Apple Tree Borer is usually found from the ground up to the limbs and

The Peach Borer can be destroyed in trees 5 years old up by spreading about an oz, of Paradichlor-benzine in a narrow ring around the tree, not closer than two inches from the trunk, and covering this chemical with several inches the fall when ground is dry.

\section{EIRE HLIGHT}

This disease sometimes attacks certain varieties of apple and pear. The small shoots turn brown and die and the bark method of control is to cut out the affected parts, making the cut six inches below any sign of the disease and burning the blighted parts. The tools and the wounds are disinfected with bichloride of mercury, corrosive sublimate, a deadly
poison, one tablet to a pint of water applied with a sponge or rag.

\section{Spray Calendar Apple, Pear, Quince}

(1)-Dormant or Seale Spray. Any time ing pleasant weather in winter and until growth starts in spring.

For-San Jose Scale, Other Scale Insects,

Use-Plant Lice (Aphids) to 7 or miscible oils. This spray may be omitted if scale is not present. Arsenate of lead is not required.

(2) - First Summer or Cluster Bud Spray. When cluster buds are separated fore the blossoms op

For-Plant Lice (Aphids), Apple Scab. Curculio, Canker Worms, Apple

Use-Lime-sulphur (11/2 to 50 ) plus 1 lb. of dry arsenate of lead. Nicotine sulphate ( $1 / 2$ pt. to 50 gal. are abundant)

(3') - Seeond Summer or Calyx-Cup Spray. and finish before the blossom ends close. Most important summer spray, apply thoroughly. (Aphids),

For-Codling Moth, Plant Lice (Aphids), Canker Worms, Lesser Apple

Use-Lime-sulphur $\left(1 \frac{112}{2}\right.$ to 50$)$, see note, plus $1 \mathrm{lb}$. of dry arsenate of lead. Nicotine, sulphate $(1 / \mathrm{pt}$. to 50 gal. of spray mixture

(4)-Third Summer Spray. Within 12 to 15 days after Calyx spray. If Cur-
culio injury is severe apply within culio injury

For-Apple Blotch, Sooty Blotch, Leaf Apot, Curculio, Codling Moth, Lesser

Use-Lime-sulphur ( $11 / 2$ to 50$)$, see note plus 1 lb. of dry arsenate of lead. If apple blotch is severe use Bordeaux

(5)-Fourth Summer Spray. Apply 5 or 6 weeks after the Calyx spray, or
if No. 4 is made within 6 to 10 days, apply No. 5,2 to 3 weeks later.

For-Apple Blotch, Sooty Blotch, Curculio, Codling Moth, Lesser Apple Worm, other biting insects.

Use-Lime-sulphur ( $1 \frac{1 / 2}{2}$ to 50$)$, see note, or Bordeaux $3-4-50$, plus i lb. of dry is severe, use Bordeaux $3-4-50$.

Fifth Snmmer Spray. Apply about 2 or 3 weeks after No. 5 or 7 to 9 weeks after Calyx spray. Make later sprays at intervals of 10 days or weeks, where

For-Coddling Moth, Lesser Anple Worm, Apple Blotch, Bitter Rot, Sooty Bloteh, Curculio, other biting insect.

Use-Lime-sulphur ( $11 / 2$ to 50 ), see note or Bordeaux $3-4-50$, plus $1 \mathrm{lb}$. of dry arsenate of lead. If apple Bordeaux $3-4-50$

\section{Spray Calendar-Grapes}

(1) - In the spring before buds begin to swell.

Use-Lime-sulphur solution, win ter strength for both Scale and Antriple strength for Anthracnose.

(2) -As buds are swelling. Repeat in For-Flea Beetle onl

Use-Lead Arsenate (dry) 3 lbs. to 50 gallons.

(3) - When shoots are showing second or

For-Black Rot, Anthracnose, Flea Beetle.

Use-Standard, Bordeaux for rot. Lead Arsenate (dry) 3 lbs. to 50 gallons for insects, if needed.

(4)-Before blossoms open.

For-Black Rot, Anthracnose, Curculio, Flea Beetle, Berry Moth. Standard Bordeaux for rot. Add 2 lbs. of soap to each 50 gallons. Use gallons for insects.

(5)-After blooming.

For-Black Rot, Anthracnose, Curculio, Berry Moth.

Use-Same as for preceding application.

(6) - 10 to 14 days after blooming.

For-Black Rot, Anthacnose, Insects.

Use-Same as for preceding application.

(7) -3 to 4 weeks after blooming.

Use-Same as for preceding application.

(8)-A bout 6 weeks after blooming. One later application may be necessary. application

For-Black Rot, Insects.
Use-Same as for preceding application.

The spray program for grapes centers around the treatment for black rot. The usual recommendations include three
spraying, before blooming, after blooming and two weeks after blooming. In vineyards where the disease is of mod- erate consequence, three sprayings may be sufficient, but where it is severe, five to seven may be required.

Sprays Required-The apple sprays ordinarily needed' are 2, 3, 4 and 5 in the northern half of Missouri, while in the southern half 5 or more sprays are genshould study carefully the conditions in his own orchard. including the insect pests and plant diseases, in order to be able to work out a spraying program

\section{Spray Calendar Cherry, Peach, Plum}

(1)-Any time after leaves drop in fall, during nice weather in winter and

For-Peach Leaf Curl, Brown Rot, San Jose Scale.

Use-Commercial lime-sulphur (1 to 7 ). If scale is not present use Bordeaux solution (2 to 50 ).

(2)-Apply after blossoming and when most of the shucks and blossoms are off the fruit.

For-Curculio, other biting insect, Peach Scab, Cherry Leaf spot, Brown Rot, Plant Lice (Aphids).

Use-Arsenate of lead, dry, $3 / 4$ lit. in selfboiled lime-sulphur $(8-8-50)$, or in milk of lime, from 2 to 3 is added stone lime. Add nicotine sulphate $1 / 2$ pt. to 50 gal, spray if plant lice are injurious.

(3)-Apply 6 to 10 days after shucks and blossoms are aff. If curculio is
not serious, 2 weeks after shucks not serious, 2 weeks

For-Curculio, other biting insect, Brown Rot, Peach Scab, Cherry Leaf Spot, Plant Lice (Aphids)

Use-Self-boiled lime-sulphur (8-8-50)

(4) - plus 3/4 lb. of dry arsenate of lead. at

For-Curculio, other biting insect, Brown Rot, Peach Scab, Cherry Leaf Spot.

Use-Self-boiled' lime-sulphur $(8-8-50)$ plus $3 / 4$ lb. dry arsenate of lead.

Stone Frults-Where San Jose Scale and Peach Leaf Curl are not present, sprays No. 2 and No. 3 will generally

During wet season, Elberta and later varieties of peaches may need later applications of self-boiled lime-sulphu $(8-8-50)$, but in no instance should any
variety of stone fruit be sprayed with this mixture later than 3 weeks before picking time. 


\section{A Good Hedge Adds Distinction to a Home}

Hedges are desirable for their beauty, for screens, for windbreaks and for barriers. They are also used effectively to outline flower gardens and for edging garden walks, pools, and planting beds. Some make a dense, solid growth and may be kept sheared in a formal shape. They are cheaper and more attractive than iron or picket fences that require painting.

\section{SHEARED HEDGES}

Japanese Barberry is the best low growing protective hedge. Its thorns keep out children and dogs but do not tear the clothes. Grows 3 to $4 \mathrm{ft}$., usually pruned lightly, plant 12 to 18 in. apart.

Privet is the most popular hedge plant and may be kept pruned at the desired height. They grow 8 to $12 \mathrm{ft}$. tall. Plant 8 to 12 in. apart. Set plants a few inches deeper than they were in the nursery and cut the tops off about 4 inches above the ground. Trim in spring before growth starts and lighter several times in summer, keeping the widest part at the base.

California Privet is the most attractive but is not very hardy. Amoor River Privet is very hardy, but loses its leaves earlier. Ibota is also very hardy.

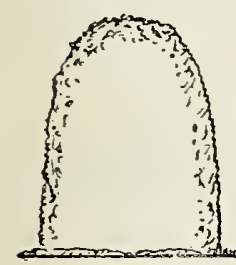

3

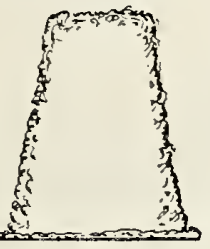

4

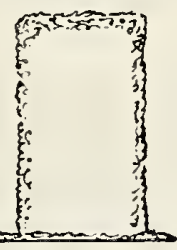

5

These are Correct Forms of Privet Hedge

FOR EDGINGS FOR WALKS AND DRIVES Japanese Barberry; Deutzia Gracilis grows 2 to $3 \mathrm{ft}$., has white flowers in May, is kept trimmed; plant 12 to 18 in. apart. Regel's Privet grows 3 to $6 \mathrm{ft}$., holds foliage into winter, is kept trimmed; plant 12 to 18 in. apart. Crimson Spirea and Dwarf White Spirea grow 1 to $2 \mathrm{ft}$. tall and blossom nearly all summer; plant 8 to 12 in. apart, untrimmed.

\section{OTHER SHRUBS USED FOR HEDGES}

The Golden Bells, Intermedia, Fortunei and Viridissima; Althea, Bush Cranberry, Snowball, Mock Orange, are planted 2 to $21 / 2 \mathrm{ft}$. apart. Hydrangeas and Conrad F. Meyer Rose are set 18 to 24 inches apart.

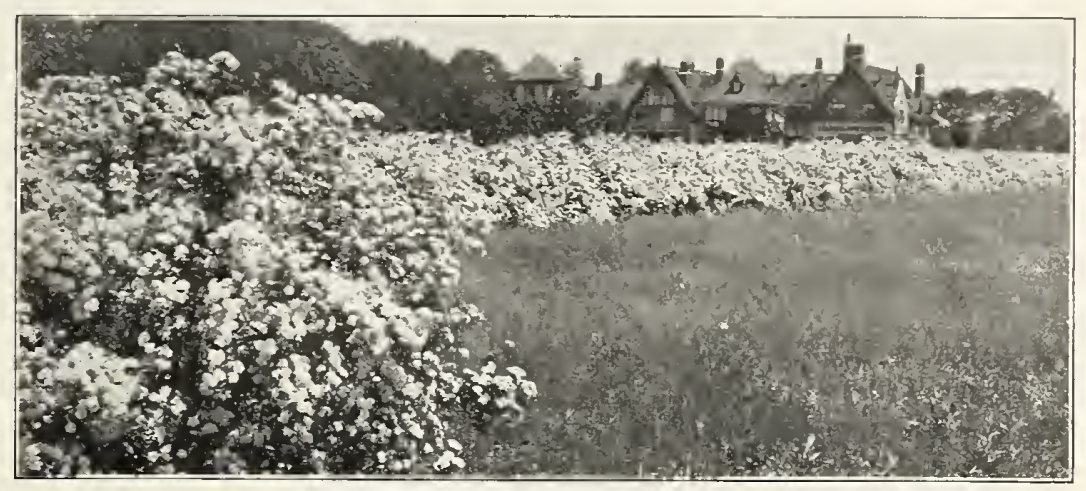

Spirea Van Houttei. Makes a Very Graceful, Free-Growing Hedge

\section{UNSHEARED HEDGES}

Japanese Barberry and the following are most used for unsheared hedges. Spirea Van Houttei has graceful arching branches, attractive green foliage and is a mass of white flowers in April or early May. Grows 6 to $8 \mathrm{ft}$. Plant 18 to 24 in. apart.

Rosa Rugosa-Very hardy, dense-growing shrub 4 to $5 \mathrm{ft}$. with shining dark green corrugated leaves, and red or white flowers followed by orange-red seed pods; endures partial shade; plant 15 to 18 in. apart.

Snowberry-Valuable for good foliage; white berries in late summer into winter; grows 3 to $5 \mathrm{ft}$; endures partial shade; plant 15 to 18 in. apart.

Coralberry-Has good foliage and graceful arched branches with clusters of red berries all winter; grows 3 to $5 \mathrm{ft}$; endures shade; plant 15 to 18 in. apart.

Barberry (Japanese). The Best Low-Growing Protective Hedge

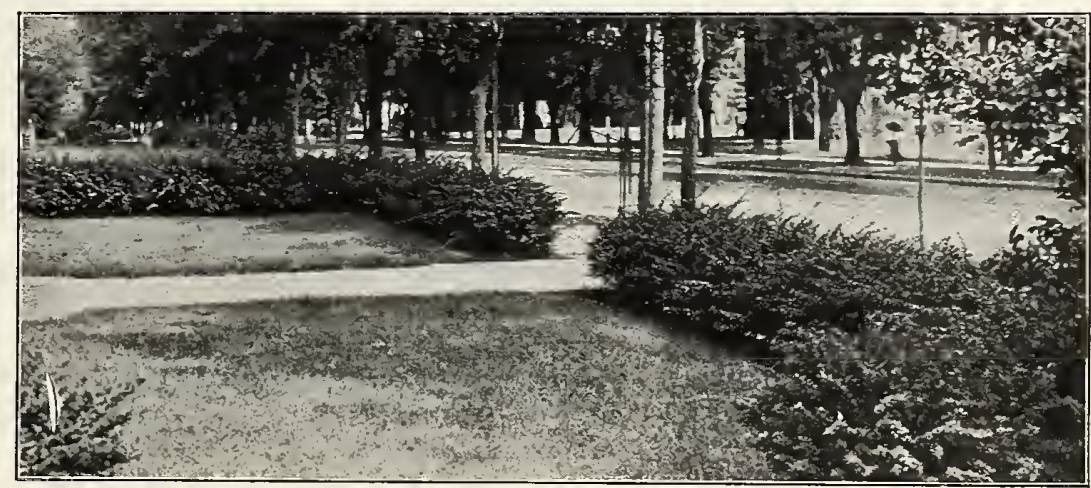

\section{Neosho Landscape Service Gives Great Satisfaction}

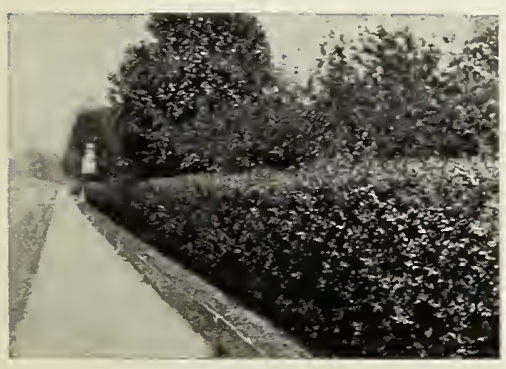

"I wish to say we were pleased with the landscaping plan. It gave many plants and groupings which were unfamiliar to us. We feel these will keep us from having that 'ordinary look' so often found in homes. Although we can not get all plants now we know in the end we will have that distinguished appearance which all desire."-March 15, 1926 , Mary Harris, Okmulgee Co., Oklahoma.
"Your drawing and suggestions for the planting of my place have been duly received and to say that I am pleased with the attention that you have given me; is putting it mildly. May. I advise that it was through the kind offices of Mr. Fred Sloan
of this place that I got in touch with your firm. Mr. Sloan owns a 13,000 apple and peach orchard here and has repeatedly told me that the best trees on his place were purchased from your firm."-John W. Jackson, Alleghany County, Maryland.

"I am pleased to report that your shrubbery and trees supplied last April proved to be very satisfactory with exception of the raspberry bushes and one cherry tree. These failures I do not attribute to you since the other stock was 100 per cent
good and beyond my expectations."-John W. Jackson, Alleghany County, Maryland. "Ny grounds are very beautiful, considering all planting was
done this spring. Practically everything was furnished by you done this spring. Practically everything was furnished by you Mexico. 


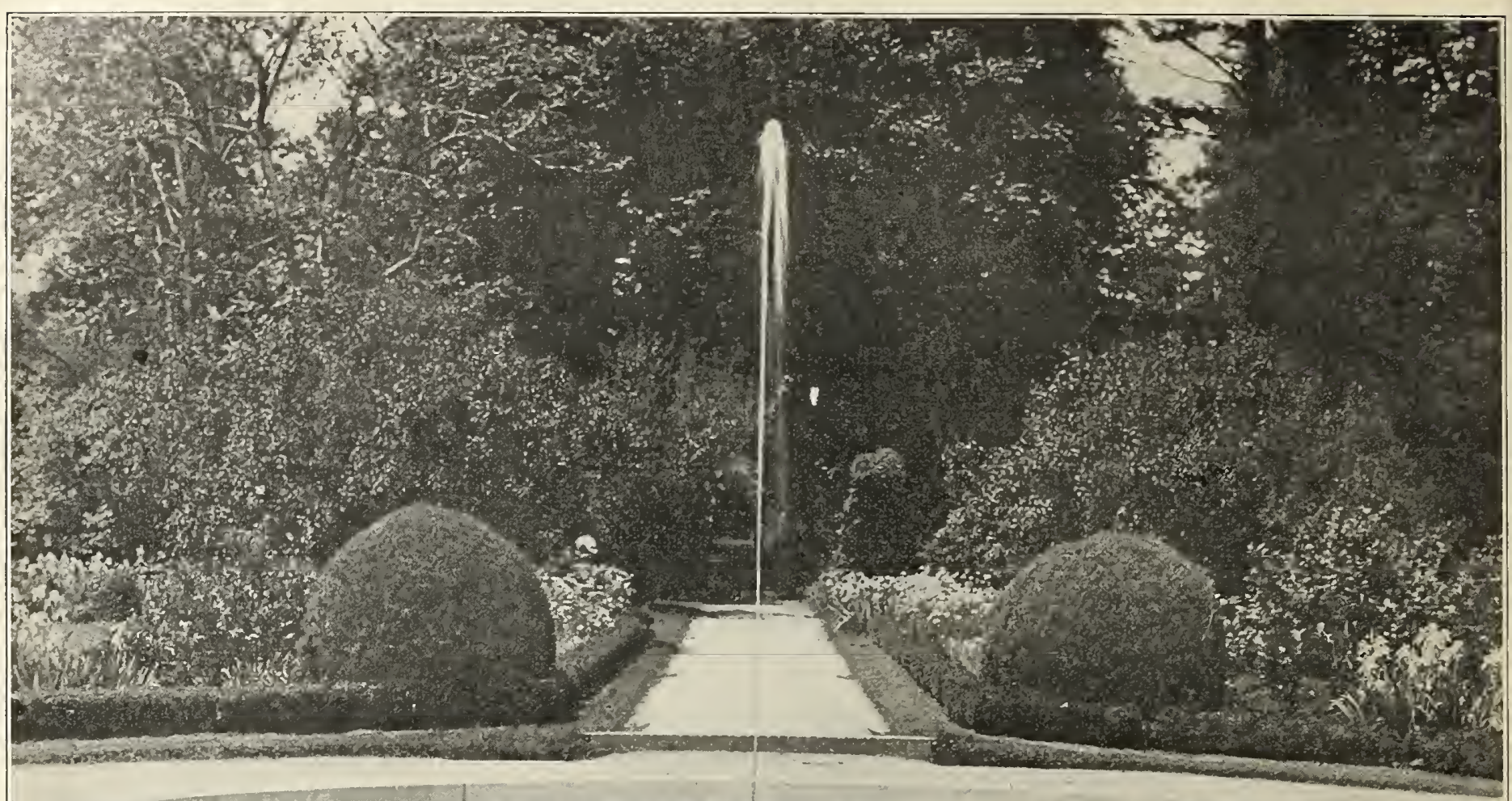

\section{Good Examples of Formal and Informal Plantings}

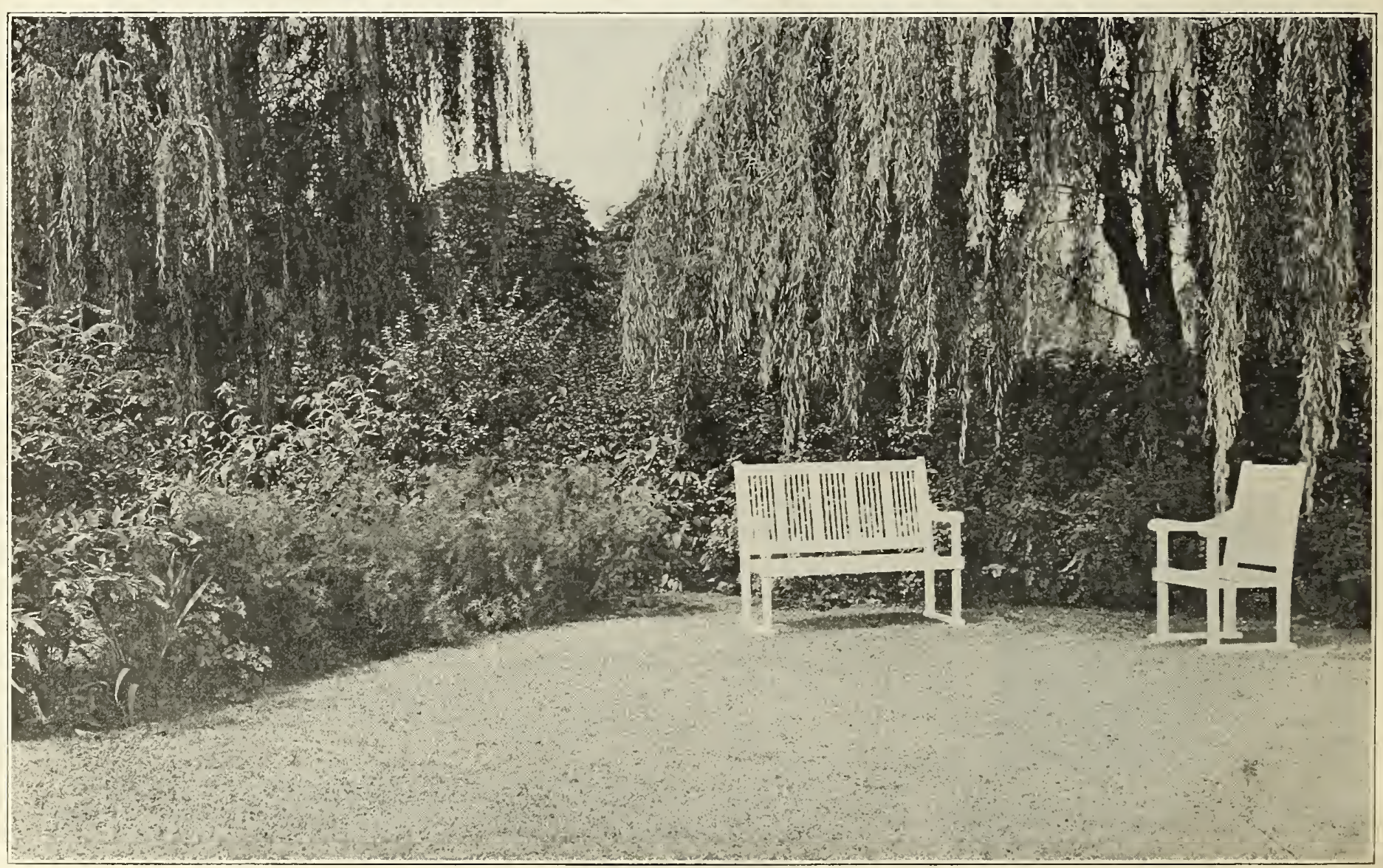




\section{The Selling Price of Beauty}

Statistics show that for every $\$ 100$ spent in proper beautification of the home grounds the owner can add $\$ 1,000$ to his sale price. Very likely you know of instances which confirm this statement, extraordinary as it may seem. In any case it is a fact which is not generally known in some sections. However, a marked change is taking place. People who a few years ago said they did not want "brush" around their homes have increased the comfort, attractiveness and value of their properties by proper use of plant materials.

Now the word "proper," as applied above, is all important because improper choice and arrangement of trees, shrubs, etc., produce results which are far from the object desired. Examples of such results are all too frequent because the designer was not familiar with the fundamental principles of landscaping nor with the habits of growth and characteristics of plant materials. For instance, Evergreens which ultimately attain a height of 40 feet obviously do not belong in a foundation planting; the Butterfly Bush, lovely as it is with its lilac flowers, is not suited for plantings around the house or where it is seen at close quarters.

There are, generally speaking, two types of landscaping-formal and informal. The latter might be termed the English style since it is used so extensively in England and in the United States. It is the natural style conforming more nearly to an imitation of Nature.

Usually home grounds are divided into three areas. First, the public area which usually is best kept open, with trees located for framing the house and along the street with possibly a hedge or mass plantings in the corners or along the sides. Suitable planting around the porch and the house will link the house to the ground. The corners will be softened and the architectural features emphasized by proper selection and arrangement of plant materials. Second, is the private area which is more or less screened from public view and may include a flower or rose garden, shrubs along the boundaries, a pool, a pergola or a tennis court. Third, the service area where the "wash" will not be flaunted to public view and where other homely but necessary operations are carried on.

The best results are obtainable only when a complete plan is carefully worked out in advance. In no other way can a harmonious effect be produced. As a matter of fact this plan should be made before the house is built or grading done or walks and drives laid.

Such a plan requires study, knowledge, experience, and good taste. The owner will need particularly to guard Formal Garden on Neosho Nurseries Ground.

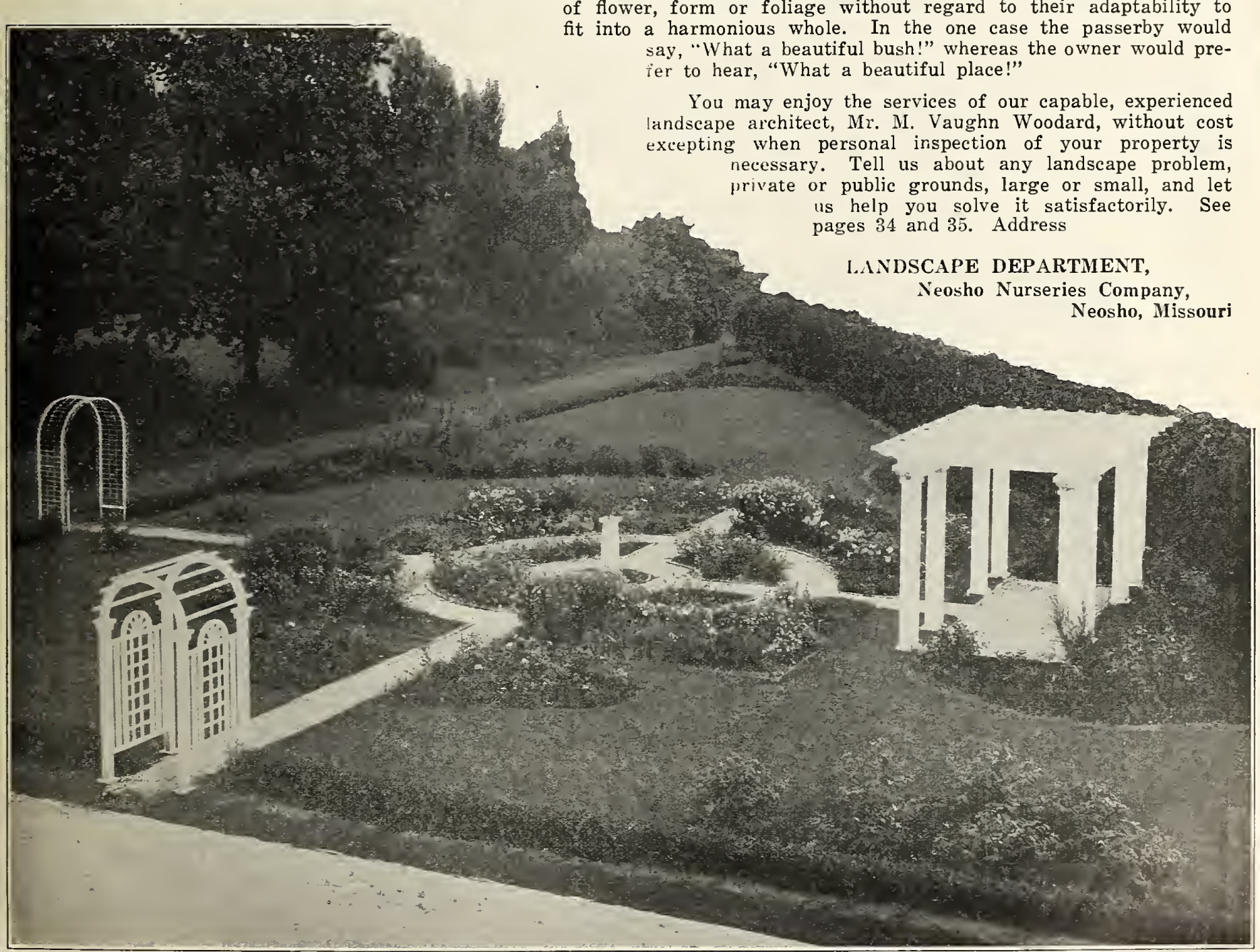




\section{Let Us Add Beauty and Value to Your Property}

Here is an example of rough sketch as sent in by a customer with pictures and other information. Be sure to answer ALL the questions on opposite page.

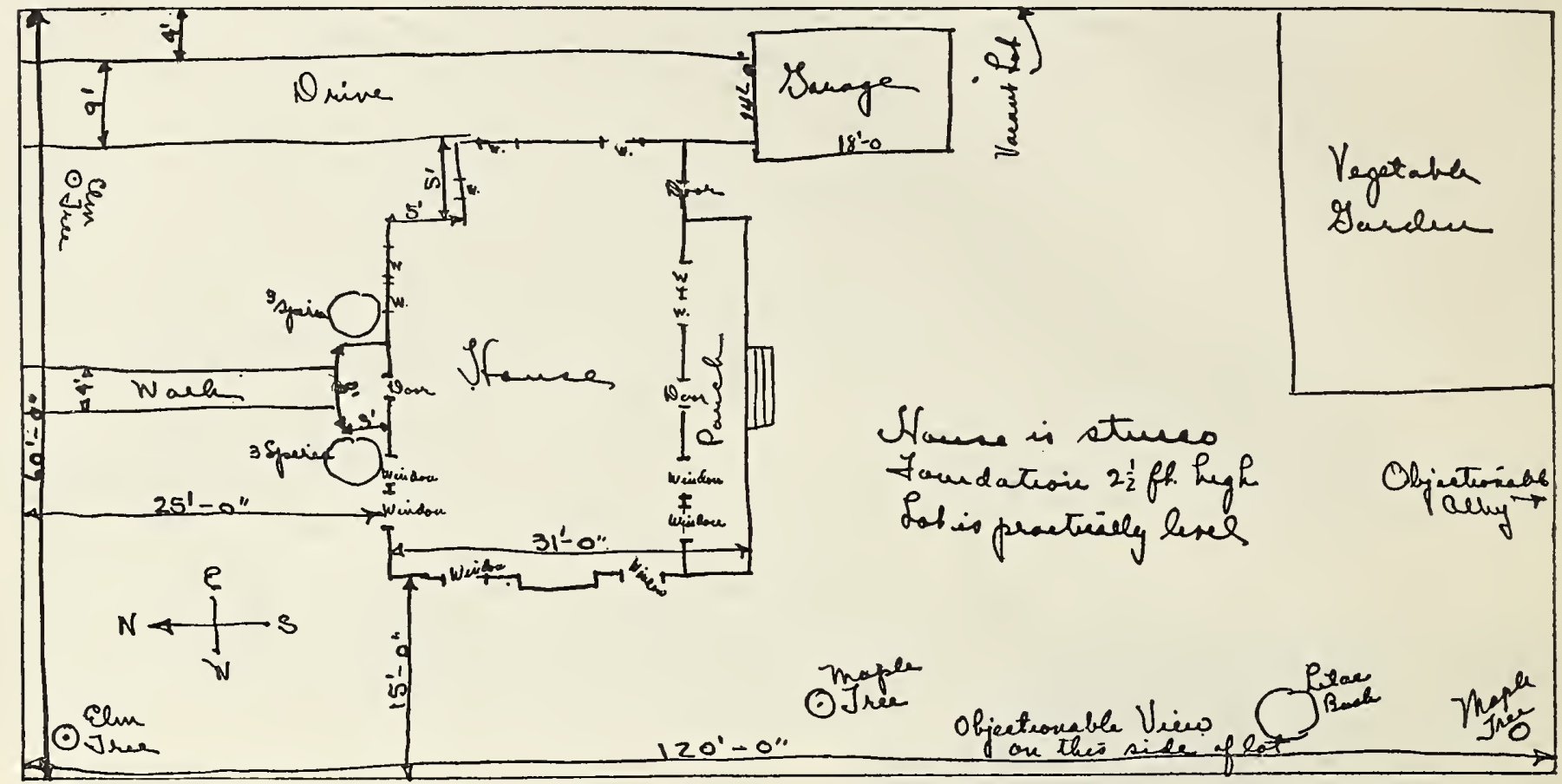

Below is an example greatly reduced of a complete plan or design as developed from above rough sketch. As submitted to the customer it would show the location and variety of each tree, shrub, vine, etc.

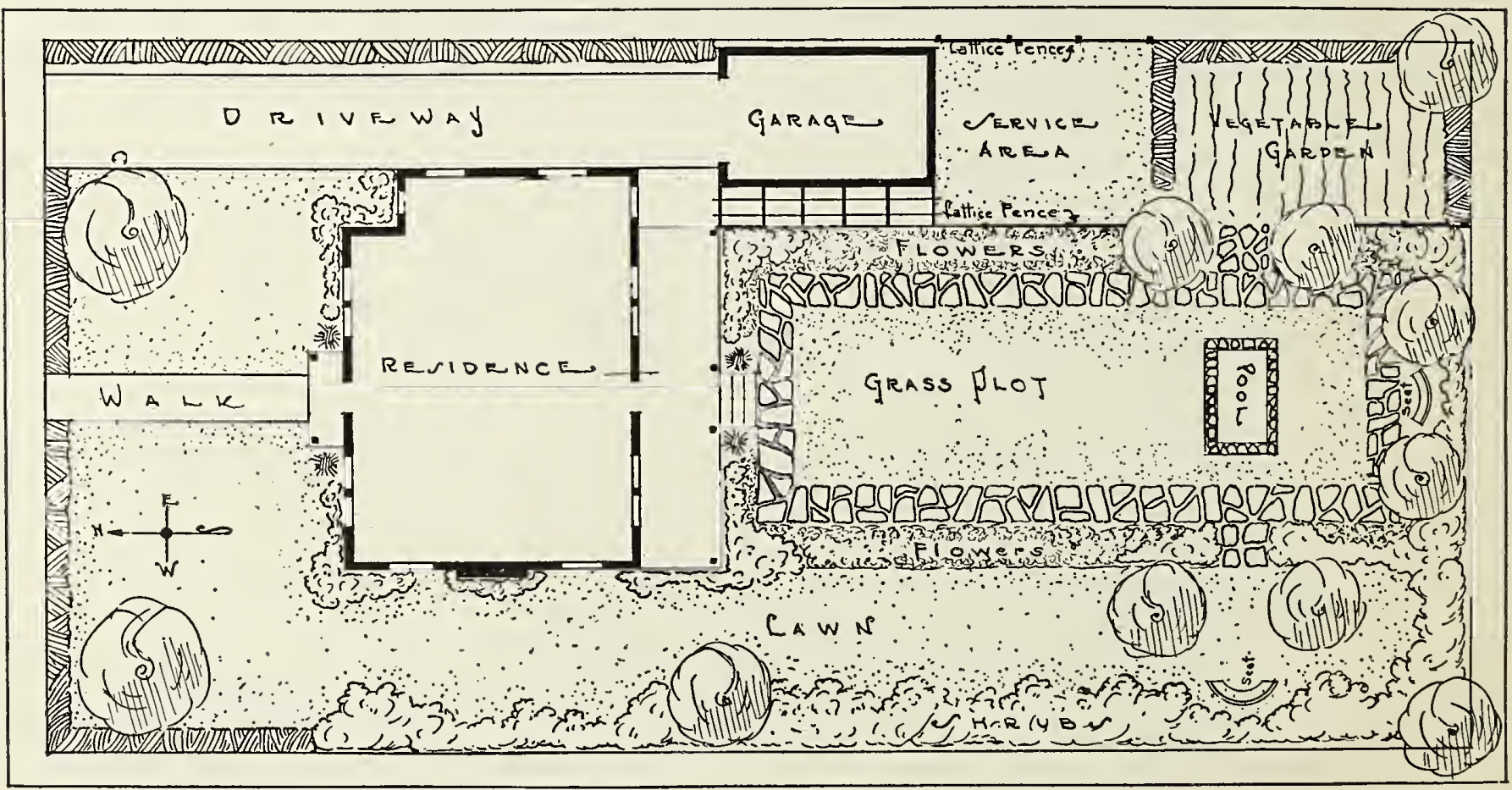




\section{Beautify Your Home Grounds the Neosho Way!}

Upon receipt of sketch and information as outlined below, we will prepare a plan for you, incorporating original ideas, giving you a practical and artistic effect throughout the year. Such a complete plan would be drawn on a larger scale than shown at bottom of opposite page and each group would be keyed and data given as to height, color and season of bloom. The location of each tree or shrub would be indicated so that the plan enclose $\$ 1.00$ at the time of mailing your sketch. This $\$ 1.00$ will be deducted on an order of $\$ 10.00$ or more. Thus you really receive this service free of charge. This offer is subject to change without notice.

\section{Send Just a Simple Sketch With This Information}

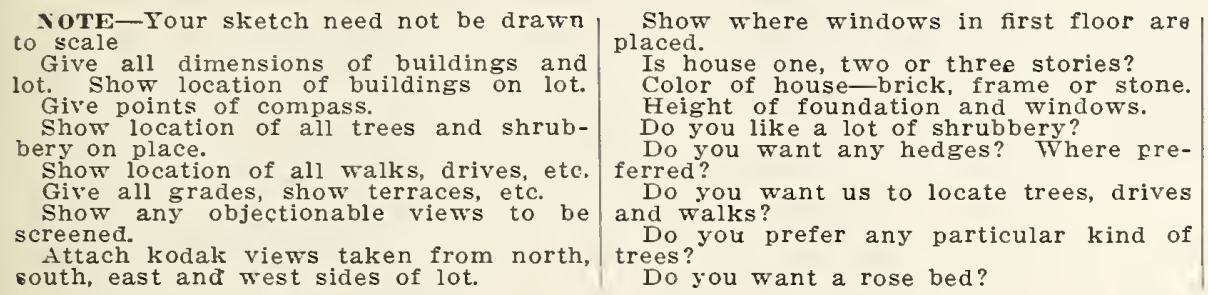

NoTE-Your sketch need not be drawn phow where windows in first floor are

Attach kodak views taken from north, south, east and west sides of lot.

\author{
Is house one, two or three stories? \\ Color of house-brick, frame or stone. \\ Height of foundation and windows. \\ Do you like a lot of shrubbery? \\ ferred? \\ Do you want us to locate trees, drives \\ and walks? \\ Do you prefer any particular kind of \\ Do you want a rose bed?
}

Do you want a formal flower garden? Do you want any fruit trees?

Do you want a vegetable garden? Where preferred?

What is the character of soil?

NoTE-For owners of larger placesSchools, Parks, etc.-We are prepared to make plans by mail, but suggest a perOur terms are reasonable for such services and will be stated in correspondence.

\section{A Beautiful Place! The Creation of An Artist}

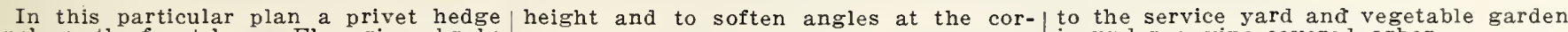
encloses the front lawn. Flowering shrubs ners.

along part of the west side and the The service yard and vegetable garden south end provide an attractive back- are separated from the flower garden by secure privacy. The house is linked to lattice fence on which are planted climbthe ground with low growing shrubs and ing roses and Boston Ivy. Evergreens at each side of the front A Japanese Barberry hedge around the

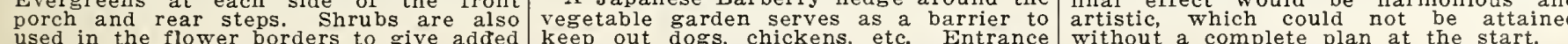

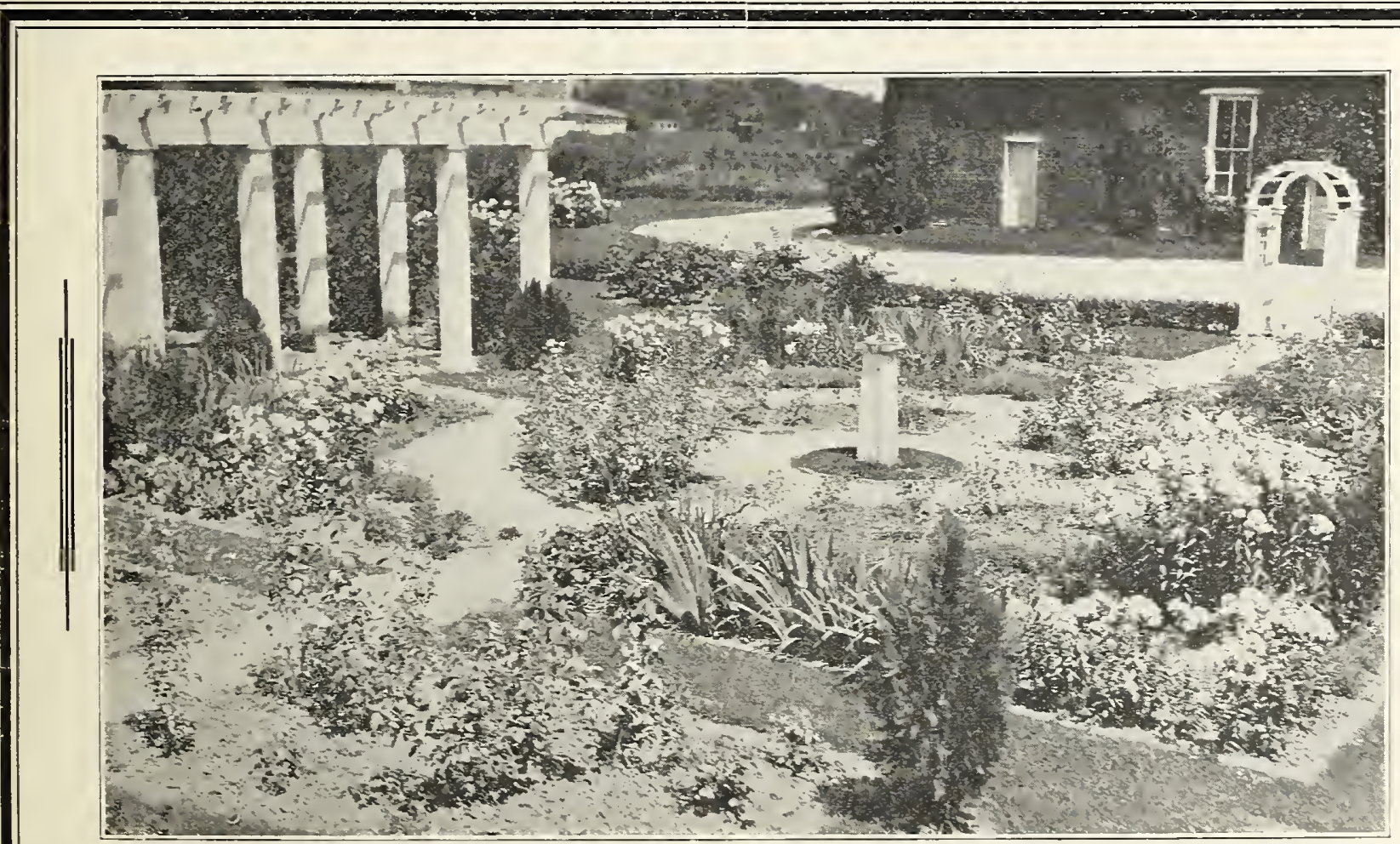

Our Formal Garden at Veosho Fourteen.Months after Planting. Designed by . H. Vaughn Woodard 


\section{How to Select the Right Shrubs For Your Grounds}

\section{Season of bloom is for Southwest Missouri and varies from year to year.}

*Indicates endures partial shade.

TALL GROWING

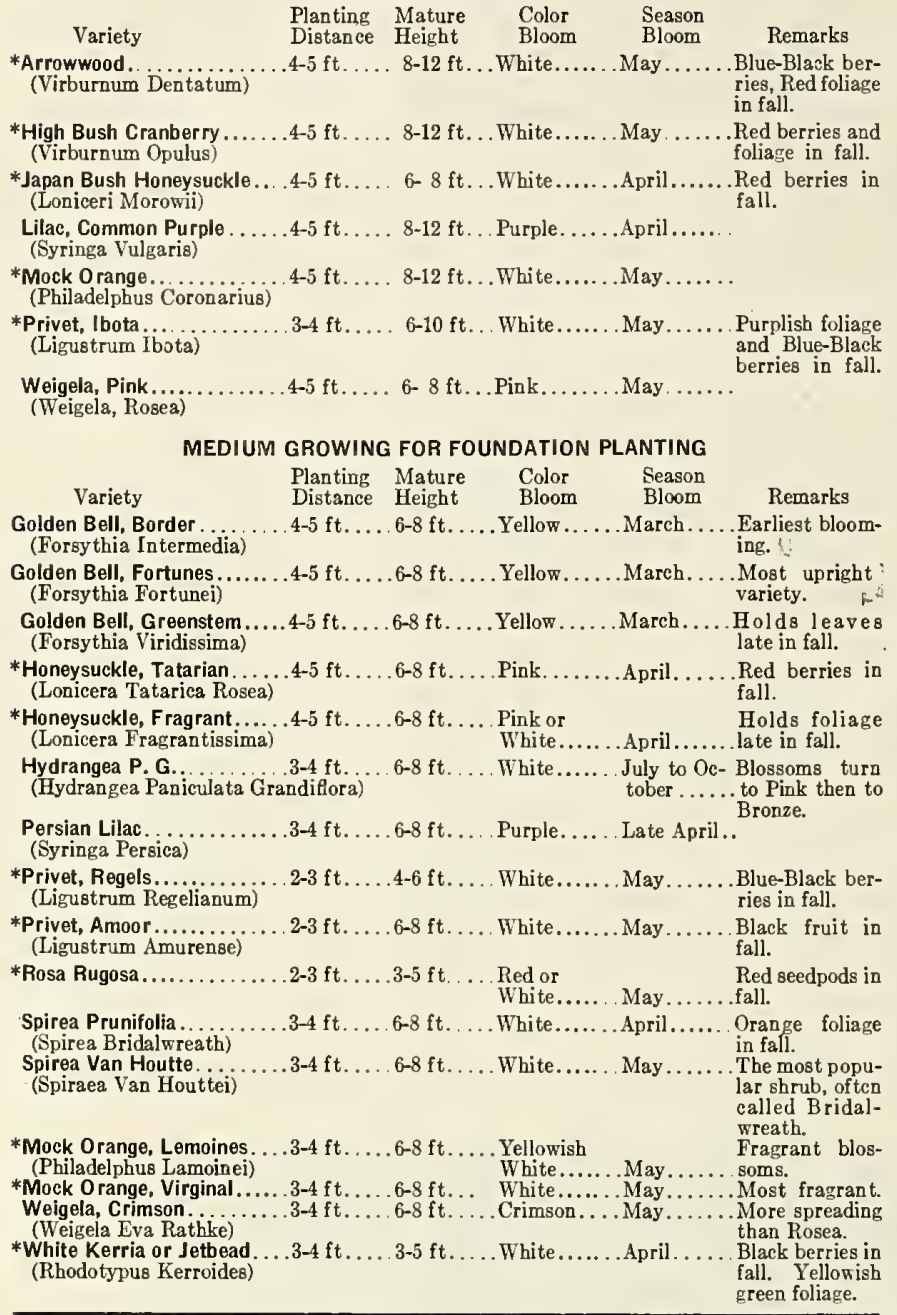

"I can report that everything (22 Shrubs) sent me last year has done well-all living and healhy. If I can mil any business your way, I certainly will."-M Mr. Kenneth P. Beattie, Allegan County,

"What stock I bought from you last spring or rather last wintrr has simply done great. The spirea boll red and white is wonderful: has a mightll fine growlh, and mos very full of blomm this the first year. Couldn't possibly be better satisfied."-Mr. Roy McGhee, ottawa County, oklahoma.

Let Your Shrub Plantings Be Curved in Ontline. Don't Cut Up Your Lawn with Flower Beds and Specinen Plants.

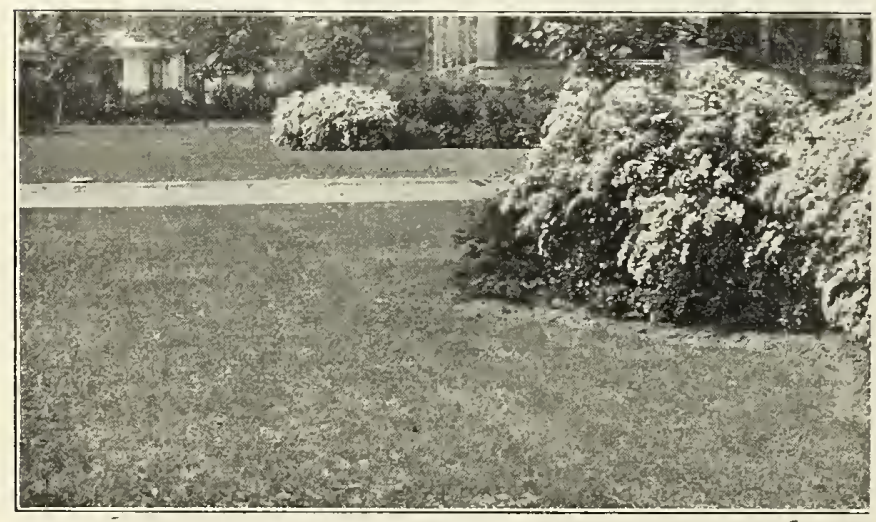

\section{LOW GROWING FOR FOUNDATION PLANTING}

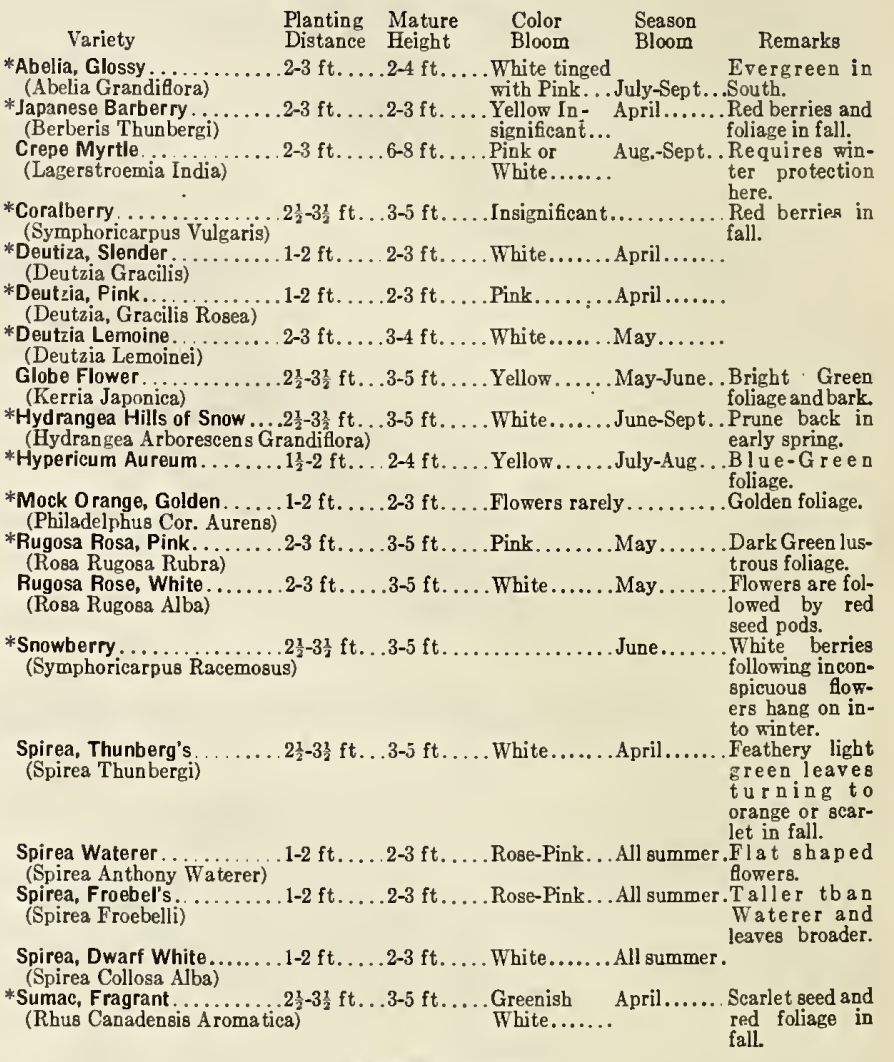

EVERGREEN SHRUBS

*Evergreen Burning Bush ....2-3 ft. . . .3-5 ft....Valuable for lustrous deep grcen leaves (Euonymus Japonicus)
and upright bushy habit. Needs winter protection fur ther north.

\section{For Border Planting}

All of Shrubs in Foundation Planting List

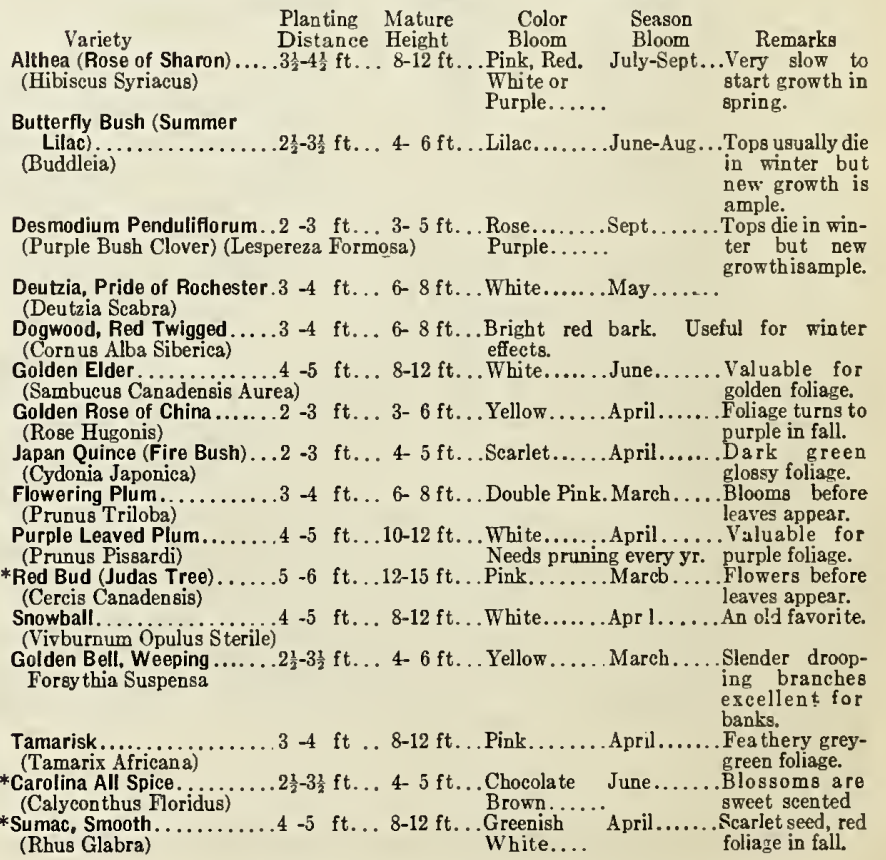




\section{Plan Your Own Grounds-Our Experts Tells You How}

Some prefer to make their own plans even though our service in presenting designs is free in most cases. Therefore we offer the following suggestions:

Locate on paper, using a scale of 8 to 20 feet to the inch, an outline of your property, putting in their proper locations the house and all existing buildings, trees, etc. You can then mark the locations for planting trees, shrubs, etc.

Too great a variety is not desirable, and most varieties make a more pleasing effect if planted in groups.

A simple lawn is best, bordered by trees, shrubs and flowers, placed to frame desirable views, screen undesirable views or objects or to secure privacy.

Plant in masses or continuous borders along the boundaries, the heavier masses at the corners.

Leave the center of the lawn open,the place for flower beds is in the back yard.

Use few varieties and a considerable number of each. Use specimen plants sparingly.

Well mowed and neatly edged lawns require shrubs that are neat in outline, with interesting foliage, flowers or fruit and that make a compact mass. The taller shrubs need lower growers in front and the texture of the foliage should harmonize, avoiding the placing of shrubs with fine texture of foliage in front of those of a coarser nature.

The lists on page 36 will help in selecting varieties of shrubs.

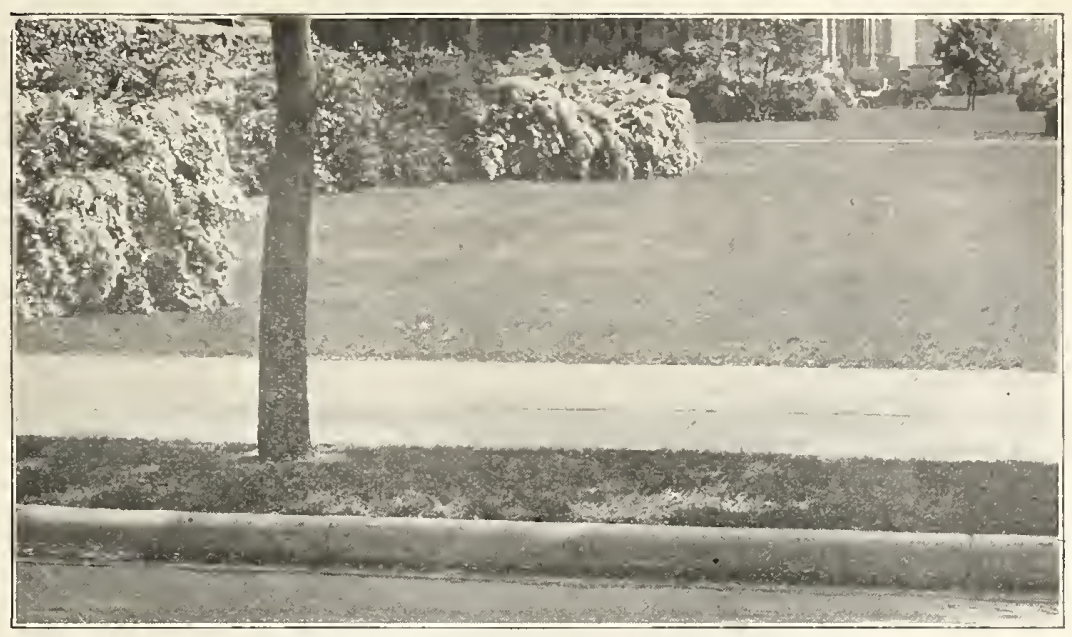

A Beautiful Combination of Lavn and Shrubs.

Lawn or border plantings are more difficult to arrange so that they will be in harmony. Whether a hedge is to be used to enclose the property or a part of it, whether groups or shrubs should be placed at the corners in the front lawn or along walles cr drives, depends upon the property.

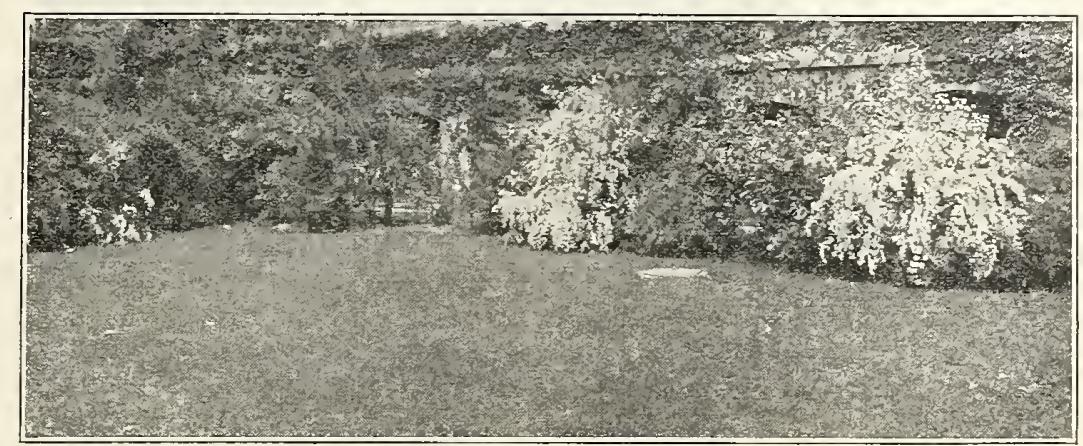

In Atrative Corner-Inviting fer Rest or Play.

If the house is set close to the ground, plantings are made only at the corners; otherwise there is need of low-growing shrubs like the Japanese Barberry, Deutzia Gracilis, Deutzia Lemoinei, Hypericum, low-growing Spireas, along the foundation, with medium growers at the corners like Golden Bell, Hydrangeas, White Kerria, Spirea Van Houttei, Weigela. Make the outline sinuous, extending out at the corners.

The shrubs on the borders should be arranged to avoid stiff, regular lines, the taller growing in the rear, smaller growers in front.

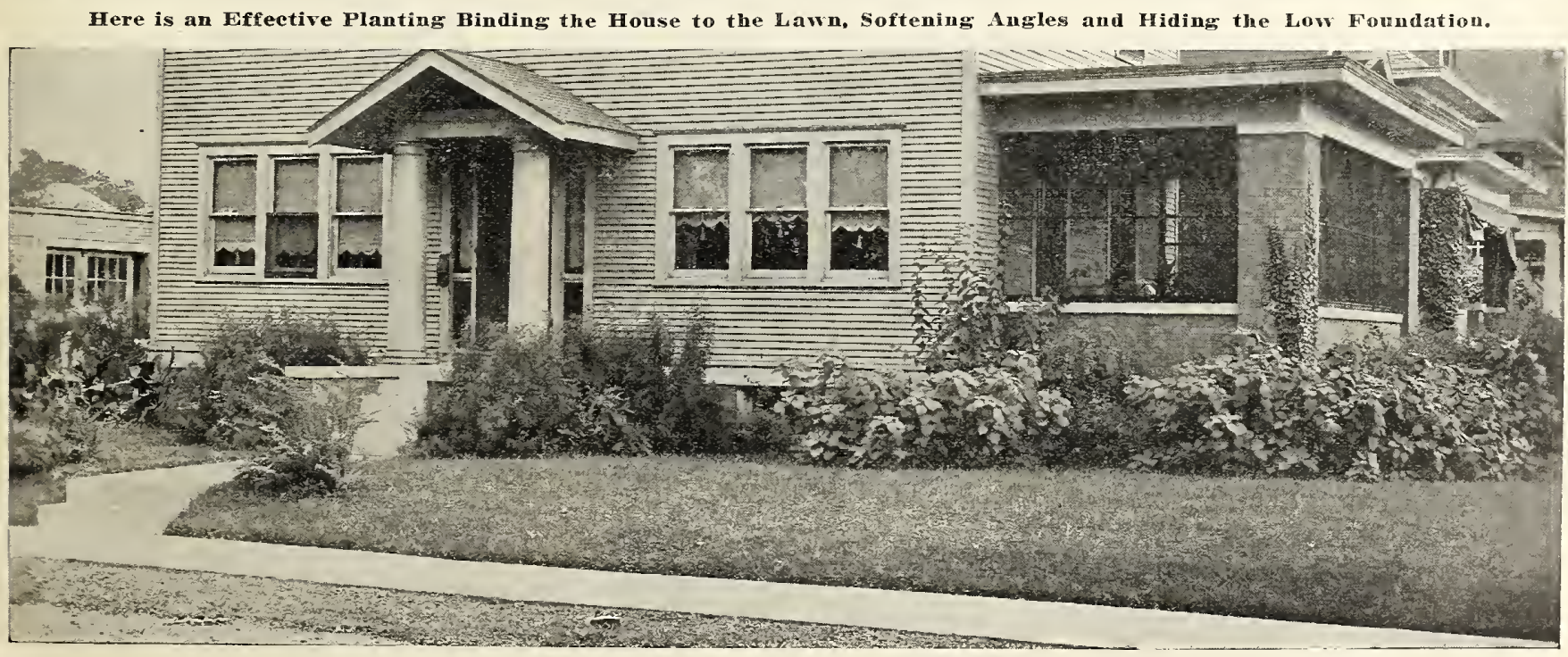




\section{Shrubs Lend Beauty and Finish to the Home}

GHRUBS are the most important ornamentals and give quickest results. They are invaluable as speci$\checkmark$ mens; in groups or continuous borders; as screens against objectionable views or to secure privacy; as barriers or windbreaks; for flowering effects, for attractiveness of foliage or fruit. They have the greatest range of color and bloom, and increase in attractiveness, usefulness and value from year to year. They relieve the harshness where house and lawn meet and the sharpness of corners. The home nestles cozily in a nest of green, instead of springing suddenly from the lawn like a Jack-in-a-box.

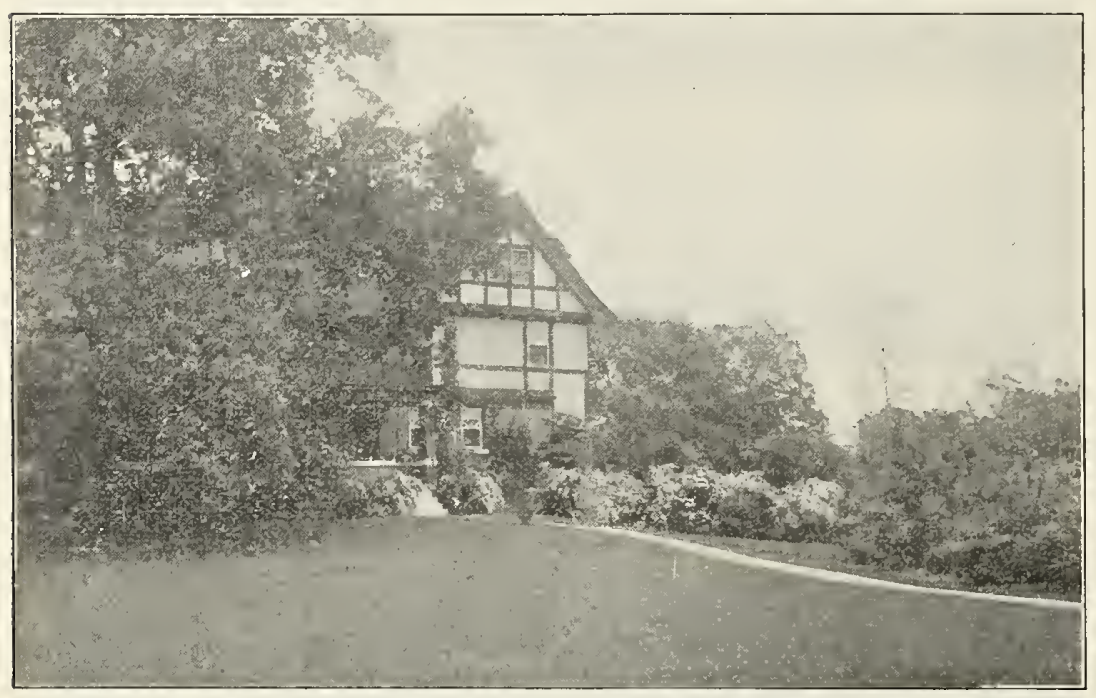

Lawn View and Shrubbery Planting.

\section{Planting Distances}

One must look ahead and picture in mind the effect when plants are mature, generally about three years.

For planting in masses or groups, spacing varies with variety and effect required:

$\begin{array}{cc}\text { Close } & \text { Normal } \\ \text { Planting } & \text { Distance }\end{array}$

Large

shrubs 3 ft. apart 4 to $5 \mathrm{ft}$. apart Medium

shrubs $2 \frac{1}{2} \mathrm{ft}$. apart 3 to $4 \mathrm{ft}$. apart Low

Sizes of Shrubs

In the purchase of nursery shrubs the average sized plants are better for transplanting than extremely large sizes. The latter have to be pruned and cut back severely and will require as much time to produce the desired effect as the average sized. Bear in mind that a small specimen of large growers like Althea or Mock Orange would be large for small growers like Crimson Spirea or Deutzia Gracilis. shrubs 2 ft. apart $2 \frac{1}{2} \mathrm{ft}$. apart

\section{Preparation of Soil}

A shrub or plant crowded into a hole dug out of the sod cannot be expected to produce satisfactory results. Beds should be dug at least a foot deep and the soil made loose and friable. Unless the soil contains plenty of fertility, well-rotted manure should be thoroughly mixed with the dirt, but never put in contact with the roots.

\section{Planting Seasons}

Plants can be moved with greatest success during their dormant period unless transplanted with a ball of earth about roots. Shrubs are dormant after buds have ripened and leaves have withered or dropped. This varies with different seasons and varieties.

Within a radius of 300 miles of Kansas City, Mo., planting is done ordinarily through November up to the middle of December, and from about March 15th to May 1st. Further South planting is done later in fall and during winter. The earlier planting is done when soil is in good condition the better will be the results.
Most trees cannot be planted close to a house without robbing it of light and air, but tall shrubs, as a background for lower ones grouped around them, take off the sharpness of the corners, and let the sunshine stream in at the windows. The tall shrubs planted as a boundary make an effectual screen, and even on the larger estates an undergrowth of shrubbery is usually planted under the trees along the boundary. Shrubs are the natural complement of trees, filling in the gap between their branches and the ground, and it is possible to get homelike results from shrubs that it would take years to acquire with trees alone.

It is cheaper to use shrubs to hide a steep bank or a deep cavity than it is to grade them. Many a house set on a narrow ridge or hilltop would appear to be less in danger of falling over the edge if the slopes around it were broadened by shrubs.

\section{Pruning When Transplanted}

Shrubs with heavy tops should have at least one-third of the tops removed. Some reduce the tops by removing entirely some canes, others partly cut back all tops. This pruning should be done in early spring before growth starts, if planting is done in the fall.

\section{Planting}

If not ready to plant when stock arrives, handle as described on page 3 . Some "puddle" roots to prevent drying out from sun or wind. This is dipping roots in a molasses-like mixture of water and loamy soil.

Bruised or broken roots must be cut off smoothly.

Set plants at about same depth as they stood in nursery. In lighter soil plant a little deeper.

Pack good soil firmly about roots. Wet soil, if needed, when hole is partly filled. Then shortly after, unless ground is moist, shrubs should be watered, but in heavy soils too much water will injure the plants.

Leave soil level with surface of ground, except a ring of dirt may be left to form a basin for watering.

\section{Winter Protection}

It is alternate freezing and thawing that does the damage. Prevent this by a heavy mulch of straw, leaves or manure put on after ground freezes.

\section{Care of Shrubs and Trees}

\section{After Planting}

Keep surface soil loose and moist and at even temperature by a 3 to 4 inch mulch of manure or by keeping a dust mulch by repeated cultivations. During a drought, water thoroughly even though mulch is applied. 


\section{Attractive Plantings Increase Property Values}

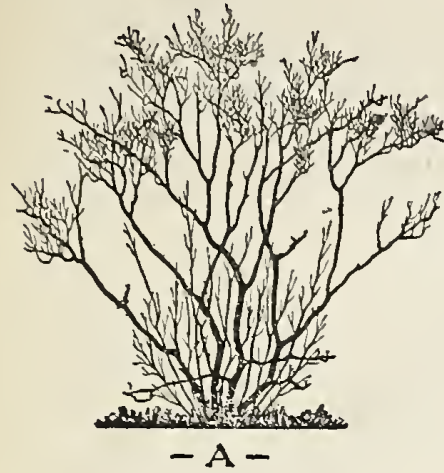

These illustrations are from "The Complete Garden" and are used by permission of the author, Mr. Albert D. Taylor.

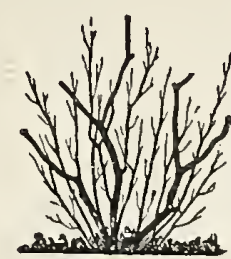

- B -

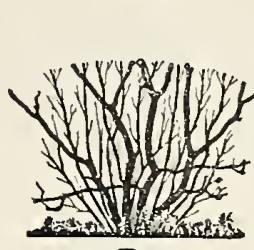

- D -

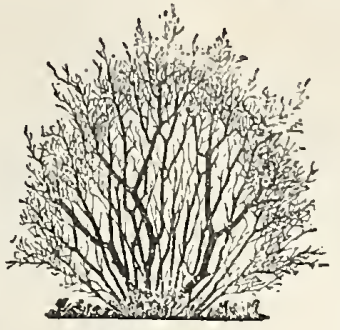

$-\mathbf{C}-$

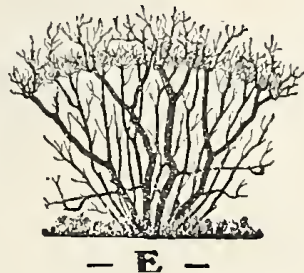

\section{Correct Pruning of Shrubs}

The object of pruning is to maintain the natural form and to preserve the flower and fruit bearing wood. Shrubs that bloom in spring or early summer should be pruned within two weeks after flowering. Those that bloom in late summer or fall, like Althea, Butterfly Bush, Hydrangeas and Snowberry, should be pruned in late winter or early spring before growth starts.

Most pruning may be confined to removing dead wood, cutting out short weak growth and heading back branches that are too long and tend to destroy the natural form of the shrub.

With old shrubs it may be necessary to cut out the old wood down to the base of the plant, encouraging the new growth from the roots.
Fig. A shows a large, overgrown shrub which is "leggy," i. e., presents a bare effect at the base. Flowers are borne in the top branches on the old wood.

Fig. B. The same shrub properly pruned to permit the new shoots to develop from the base of the shrub and to form a new top.
Fig. C. The same shrub two or three years after proper pruning, a more handsome shrub in form and with better bloom.

Fig. D shows incorrect pruning of shrub in Fig. A.

Fig. E shows the results of incorrect pruning illustrated in Fig. D.

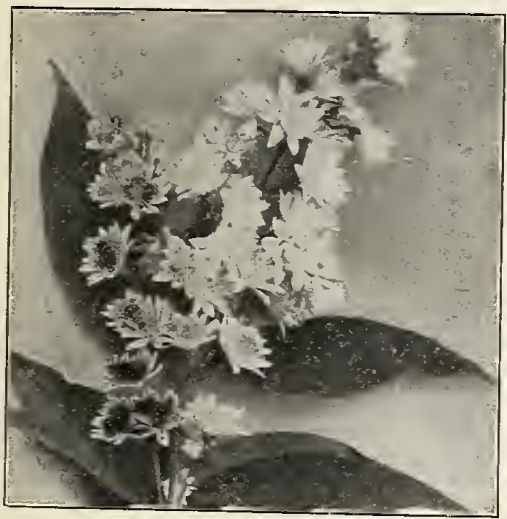

Deutzia, Pride of Rochester

ABELIA GRANDIFLORA-A very pretty shrub of unusual value. Mature height 2 to $4 \mathrm{ft}$. Blooms profusely from July to September. Leaves glossy green turning coppery red in the fall flowers tube-like, about an inch long, white blushed with pink; fragrant. Holds its foliage all winter as far north as Tulsa. Deciduous farther north but hardy as far north as Kansas City.

ALMOND, FLOWERING (Amygdalus)Grows 3 to $6 \mathrm{ft}$ tall. In late April the branches are covered with beautiful double, pink flowers before the leaves appear.

ALTHEA OK ROSE OF SHARON (Hibiscus Syriacus)-These popular shrubs have a compact, upright growth, attainin a height of 8 to $12 \cdot \mathrm{ft}$. Abundant flowers in white, pink or red, according to variety, a ppear in July to September when few other shrubs are in blossom. Valued as specimens, in shrub masses, as screens and for hedges, trimmed or as screens and for hedges, trimmed or after transplanting, sometimes showing no signs of life for 30 days.

ARROWWOOD (Viburnum Dentatum) Attractive green leaves turning red in fall, white flowers in May followed by dry or moist soil and grows 6 to $8 \mathrm{ft}$.
BARBERRY, JAPANESE ( Berberis Thunbergi)-One of the most valuable all-purpose shrubs, will grow in almost any soil, in sun or shade, dense growing: three to five feet; perfectly hardy. The leaves are small, perfectly hardy. spring and summer, scarlet in fall into winter. The twigs are thorny and covered with scarlet berries in fall and winter. Its yellow flowers are inand winter. Its yellow flowers are into plant against foundation of house to plant against foundation of house or porch, in front of taller shrubs and the best low hedge. Minor)-A dwarf form which makes a small, compact hedge, one to two feet high.

BUSH CLOVER (Desmodium Penduliflorum)-Valuable for great profusion of pea-shaped, rose-purple flowers in September to late October. Grows 2 to $3 \mathrm{ft}$.; tops die down in winter. Usefu. in shrub masses or borders.

\section{DEUTZIA}

These well-known shrubs bloom profusely in spring or early summer, have good foliage and are very useful in groups, in mass plantings, and the dwarf arieties for foundation plantings.

Deutzia Gracilis-A dense upright grower in April or early May. Very hardy, in April or early May.

Deutzia, Lemoinei. One of the Best Low Shrubs.

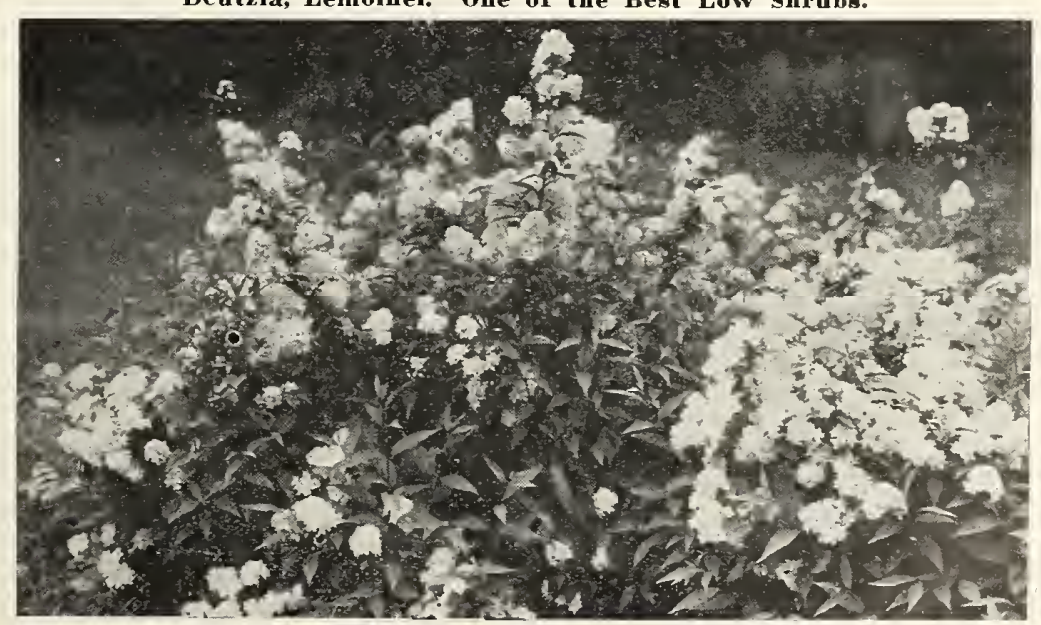

Dentzia Lemoinei-Hardy spreading grower 3 to $6 \mathrm{ft}$. With showier late white flowers than Gracilis. Endure partial shade.

Dentria, Pride of Rochester-A fast upright grower 6 to $8 \mathrm{ft}$. Double flowers, pink in bud, white when fully opened. CTERE (Buddleia)-This shrub, 3 to $6 \mathrm{ft.}$ is valued for its dark
blue "lilac" flowers borne in long spikes in late July and August. It is usually cut back to the ground in late winter, and makes a quick, bushy growth. (Symphoricarpus vulgaris)-This shrub grows 3 to $5 \mathrm{ft}$, has good foliage till late in fall; graceful, arching branches studded with small clusters of dark red berries that remain all winter. The small green flowers in August are incoil Excellent for banks to prevent

DOGWOOD, SIBERIA (Cornus Alba Sibirica)-Valued especially for coralred stems. Some of older stems should be cut out each spring to encourage has white that shows color best. It berries into winter. It is fast grow ing, 6 to $8 \mathrm{ft}$., and is used for screen effects. Endures partial shade screen varieties have grey, green and yellow 


\section{Buy Neosho Shrubs, Well Branched. See Price List}

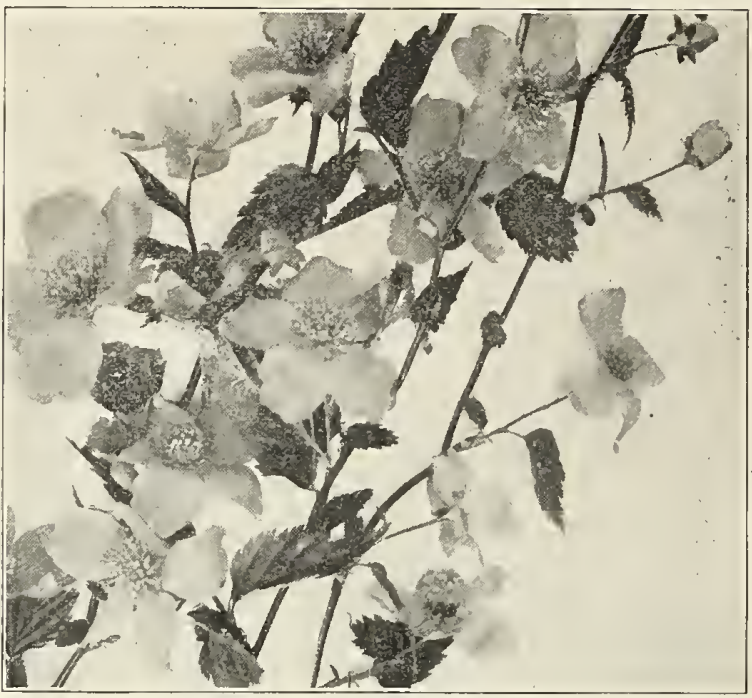

Globe Flower (Kerria Japonica).

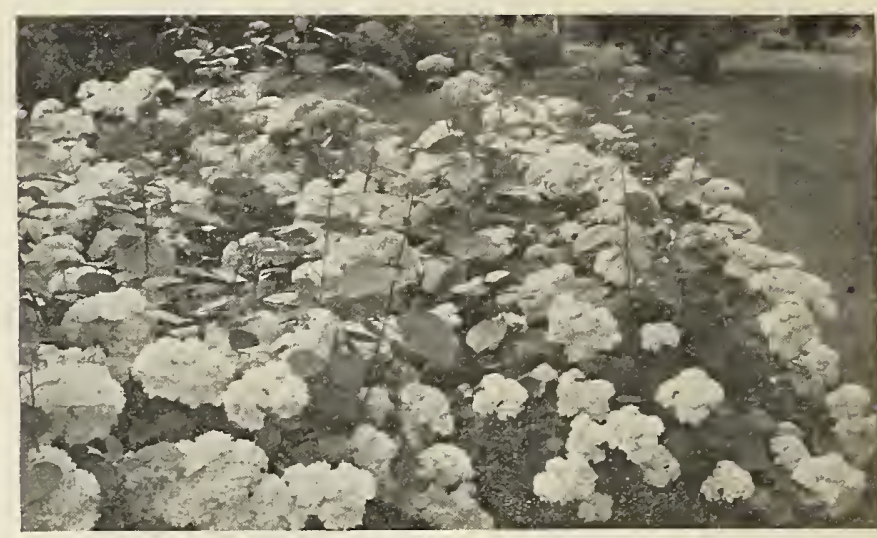

Hydrangea Arborescens (Hills of Snow).

HYDRANGEA

These deservedly popular hardy shrubs with showy white blossoms and long blooming season are used in groups, in masses with other shrubs and as specimens. Prune in late winter or early
spring, severely for large flowers, lightly for greater quantity of smaller blossoms.
hLowering PLUM (Prunus Triloba)Valued for its wealth of double pink flowers on slender branches in late April or early May.

GLOBE FLOWER (Kerria Japoniea)Valuable for beautiful yellow flowers in May, for bright green foliage in winter. Grows 4 to $5 \mathrm{ft}$.

GOLDEN MELL (Forsythia)-Golden Bells are hardy, fast growing shrubs with good foliage which follows showy

The yellowish green branches are attractive in winter. Grows 6 to $10 \mathrm{ft}$ Used in mass and border plantings.

Border (Intermedia)-The tallest grow-

Fortunes (F. Fortunci)-The most upright growing, makes good hedge.

Greell Stem (F. Viridissima)-Leaves turn purplish in autumn. Not as hardy as other Golden Bells.

Weeping (F. Suspensa)-G r a c e f $u$ branches, long slender, drooping. Used to trail

GOLDWN ELDEIR (Sambuens Canadensis Iurea)-Valuable for golden foliage throughout the summer. Grows $s$ to 12 ft.

HFGH-IBUSH CRANEERRY, MERICAY (Viburnum opulus oxycoceos) Valuable for good foliage and red berries summer and slender green of twigs in yellow flowers. ing, earliest to bloom

ing, 8 to $12 \mathrm{ft}$ tall. White flowers in flat clusters in May. Endures shade.

\section{HONEYSUCKLE (LONICERA)}

The Bush Honeysuckles are hardy, fast growing, have fine foliage and are usefu in mass plantings. They endure partial shade.

Morrows (L. Morrovi)-Its early white flowers are not showy but are followed by attractive red berries that hang on into winter. Grows 6 to $8 \mathrm{ft}$. tall broad and spreading.

Ioink Tartarian (L. Tartarica IRosea)Attractive pink flowers are followed by bright red berries. Taller growing and more upright than Morrowi.

Frogrant (L. Fragantissima)-Its pinkish-white flowers appear early in the spring, but are not showy but are green leaves hang on into winter.

Hugonis Rose, a Chinese Briar "The Golden Rose of China"), is a very attractive shrub valuable as specimens and with other shrubs. Mature height up to $6 \mathrm{ft}$. and the same in width. Quite hardy. In late April the slender branches of previous season's growth are covered with clear, yellow, single flowers. The abundant new growth from the roots are reddish-maroon and

Hydrangea Paniculata Grandiflora.

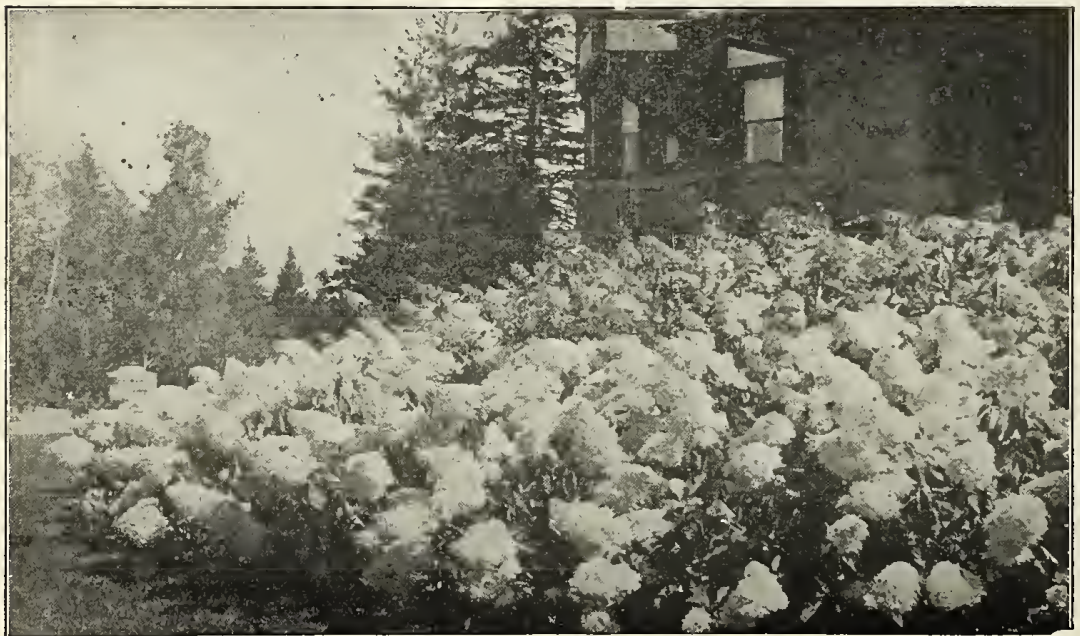

Hills of Suow (H. Arborescens Grandiflora)-Grows 4 to $6 \mathrm{ft}$. tall, and endures partial shade. Dense balls of small white flowers in June and July.

Peegee (H. Paniculata Grandiflora)Grows 6 to $\delta$ ft., large panicles of white flowers July to September changing to pink and bronze after frost. Grown in bush and also tree form.

HYPERICEM, GOLDEN S'T, JOHNS WORT (Hyperieum Aureum) - A stiff, dense shrub 2 to $3 \mathrm{ft}$., with bright yellow flowers in July and early August globe shaped top and grey-green leaves. Endures partial shade.

\section{LILAC (SYRINGA)}

The Lilacs are valuable for fragrant flowers and rich green foliage, used in groups, in masses and for hedges, requires sunny location. Prune only after blooming, removing the dead blossoms.

Common Purple (S. Vulearis)-This oldfashioned shrub is still a favorite with its fine follage and fragrant tawers The variety S. Vulgaris Alba has white flowers.

Hybrid Lilacs-The following budded Lilacs grow 6 to $8 \mathrm{ft}$. tall, have smaller leaves and larger blossoms. Lemoinei, double white; Pres. Grevy, double light blue.

Persian Lilaes (s. Persica)-Have slender branches, narrow leaves and grow 4 to 6 fi. tall. Fragrant pale lilac flowers. There is also a white variet S. Alba.

Honeysuckle, Mush (Lonieera Morrowi).

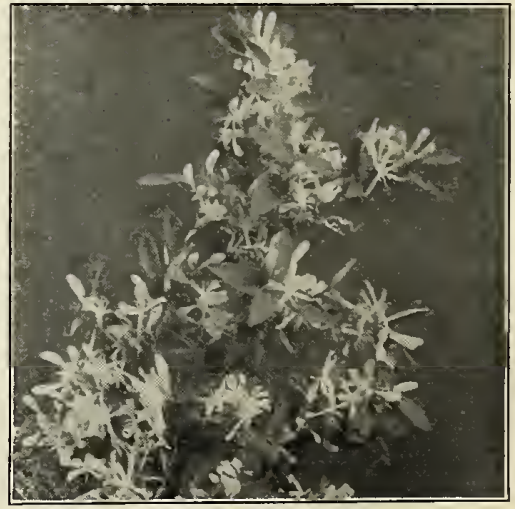




\section{All Home Grounds Need Some Beautiful Shrubs}

MOCIS OR.ATE (PHIL.ADELPHIS)

These attractive shrubs are justly popular for attractive foliage and creamy white fragrant blossoms. They are valuable as specimens, for screens and in shrub groups, Sometimes incorrectly called syringa.

sweet Mock Orauge (Philadelphus Coronarius)-This is the well-known Mock Orange with fragrant white flowers in May. Grows $s$ to 12 ft., endures partial shade. Used for hedges in shady places.

(iolden Hock Orange ( 1 . C. Iureus) Twarf habit, grows 3 to 5 ft. Used for edging walks and for garden borders.

Lemoines llock Orange (P. C. Lemoinei -More graceful, lower growing, 6 to $s$ ft. and smaller leaves than Sweet or Common Mock Orange. Wh

Virginal Jock Orange (P. Virginiualis) - A new variety with large whit flowers, very fragrant, in bloom ovel a wers, very fragrant, in bloom over growth is compact, 6 to $\mathrm{s}$ ft. tall.

IRIGOSA ROSES (ROSA RUGOSA) Are exceptionally hrady, healthy and thrive under most difficult conditions of soil and climate. The branches are spiny and the leaves are shiny dark green, curiously wrinkled and not susceptible to attacks by insects, endure dry soil and partial shade. The flowers dry soll and partial shade. The flowers come in May and are followed by red or orange-scarlet fruits which hang on other shrubs as for low unsheared hedges. Rosa Rugosa Alba-Has large, clear White flowers. Mature height 3 to $5 \mathrm{ft}$.

Rosa Rugosa Rubra-Has large rosycrimson flowers. Mature height 3 to $5 \mathrm{ft}$.

Conrad F. Meyer-Has large silvery pink, fragrant flowers, and grows 6 to $10 \mathrm{ft}$.

\section{PRIVETS (LIGUSTRUMI)}

Regels Privet (Ligustrum Ibota Regelianun)-This shrub is useful for border planting and low-sheared edg ings for walks and for garden borders and to fill in with other shrubs which has white flowers and blue-black has whit

Other Varieties, see page - under Hedges.

QLIXCE, JAPAX (Cydonia Japonica)Attractive for scarlet-crimson flower in April, and glossy green foliage as specimens and for hedges. 4 to $6 \mathrm{ft}$. SXOWBAL (Viburnum Opulus sterile) white flowers in large globular cluster White flowers in large globular cluste
in May or June; grows 8 to $12 \mathrm{ft}$.

Snowball (Viburnau opulus sterile).

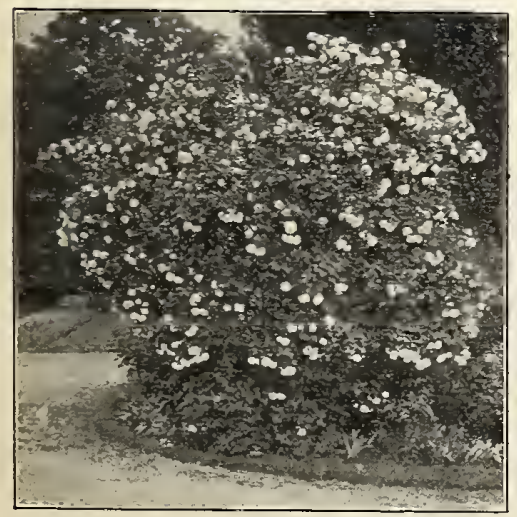

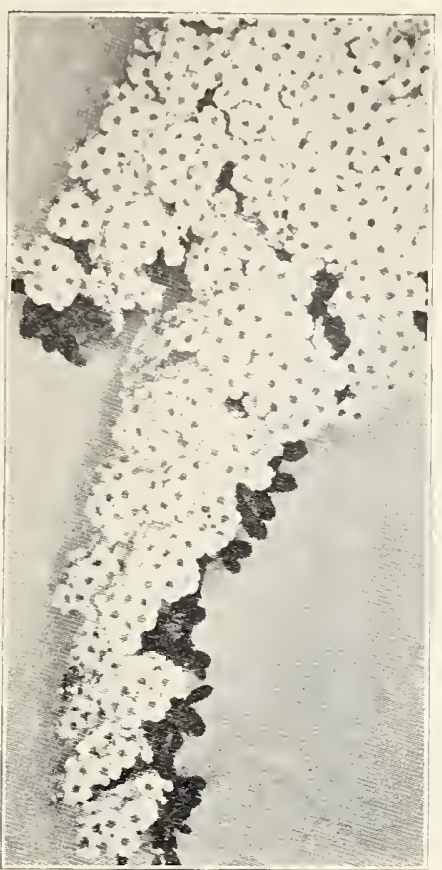

Spirea Vau Honttei.

SYOWHERRT Asmphoricarpos Racemosus -Valuable for good foliage and for white berries into winter. Flowers white in July are inconspicuous. Endures partial shade; grows 3 to $6 \mathrm{ft}$. Used for border plantings, for low, unprosion.

SUYAC, FRAGRANT (Rhus Canadensis Iromatica ) This low-spreading shrub, about $3 \mathrm{ft}$. high, is valuable for good foliage turning to red in autumn, and foliage turning to red in autumn, and dor attractive red berries. Adapted to plantings. Leaves are fragrant when plantings.

SUMAC, SMOO'TH (Rhus Glabra)-Attractive fern-like foliage, with red leaves and fruit in fall. Grows 8 to $12 \mathrm{ft}$. Adapted for banks and rocky mass plantings.

\section{Spirea (Spiraea)}

This is a large family of valuable shrubs varying in size, in habits of growth, and in color and season of bloom. A fertile soil and sunny exposure protheir best development.

Billards Spirea (S. Billardi)-Upright grower, 6 to $S$ ft.. with pink flowers

Rosa Rugosa-1lba.

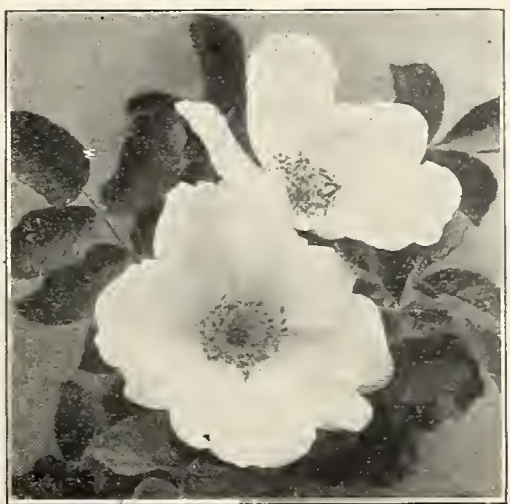

IBridal Wreath (s. I'runifolia) - Often graceful shrub with white flowers in great profusion in April. The folia is bright green turning orange-red in the fall. Grows 6 to ft. The variet "Flore Plano" has double flowers.

Crimxon spirea is. Bnmalda inthom Waterer,-Flowers nearly all summer,
bright red in flat clusters, narrow bright red in flat clusters, narrow leaves, upright grower, 1 to 2 ft.
often used for edging walks and for
garden bolders.

Dwarf White spirca (S. Callosa llba) The white flowers in flat clusters are borne nearly all summer. Grows 2 to $3 \mathrm{ft}$. Often used for edging walks and for garden borders.

Dwari link spirea (S. IBumalda)-A spreading bush 2 to $3 \mathrm{ft}$. tall with dark leaves and bright pink flowers in May

roebel's spirea (s. Frobeli)-Is one of the finest Spireas, similar to Anthony Waterer but somewhat taller and with is covered with bright crimson flowers and the leaves turn purple in fall.

Thunberg"s Spirea (S. Thunbergi)-Sometimes called Snow Garland-A spreading grower, 3 to 6 ft., with feathery ing grower, 3 to 6 ft., with feathery in profusion in April. Foliage turns in profusion in April. F

Van Houtte's spirea (S. Van Houttei)The most popular shrub. It is valuable as specimens, in groups, in border plantings, and for hedges. The with white flowers in April or early May, and the leaves are small and light green. It grows 6 to $8 \mathrm{ft}$. and is unsurpasse

TAMARISK. IFRICAN (Tamarix Africana)-A graceful shrub or small tree. light pink flowers in May.

WEIGELA, EVA RATHKE-Large trumpet-shaped crimson flowers in May and June. Bush is upright, but more spreading with age, grows 6 to $8 \mathrm{ft}$. tall. Very

WEIGELA ROSEA-Abundant showy flowers vary from white to deep ros pink in May or June. Grows 6 to $8 \mathrm{ft}$ border plantings.

WHITE KERRIA IRhodotspus Kerroides, - Valuable for bright green foliage and white flowers in May and age and white fowers in May and Endures shade; grows 6 to $8 \mathrm{ft}$. tall; hardy.

Weigela Rosea.

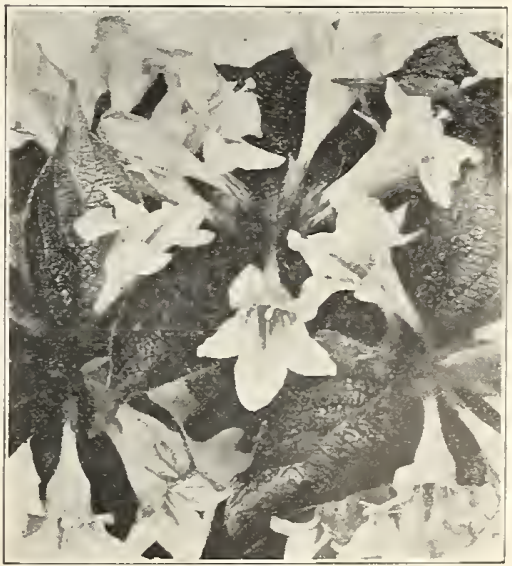




\section{Have Roses of Rarest Beauty This Summer}

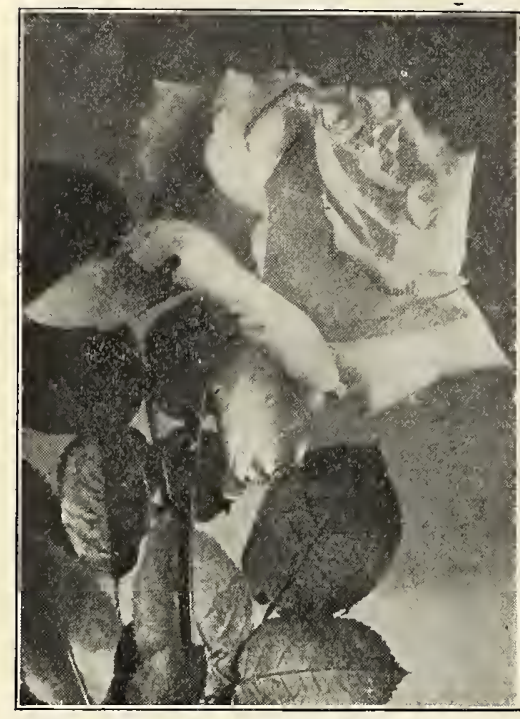

Maman Cochet

\section{Hybrid Tea Roses}

The Hybrid Tea Roses bloom more constantly than the Hybrid Perpetuals, but are not as hardy, requiring winter protection north of St. Louis.

GRUSS AN TEPLITZ-Dazzling scarlet; fragrant; one of the best deep red roses for continuous bloom; hardy.

KAISERIN AUGUSTA VICTORIA-Flowers are full double; creamy white; fragrant; continuous bloomer on long stems. Very hardy.

KILLARNEY - Clear, bright pink on long stems; excellent for cutting. Very hardy.

LA FRANCE-Light, silvery pink, very double and fragrant. Strong grower, moderate bloomer.

MADAME CAROLINE TESTOUT-Large size, bright pink, fragrant. Not a prolific bloomer, but very hardy.

OPHELIA-Deep yellow on opening but quickly fades lighter except in the center. Tall but not bushy plant; dependable but not profuse bloomer. Quite hardy. Excellent for cut flowers.

RADIANCE-One of the best and most popular pink roses. Grows bushy and tall, is one of the hardiest, resistant to disease and a liberal bloomer.

RED RADIANCE-A brilliant crimson. In other respects the same as Radiance.

SUNBURST-Bronze-yellow; fine for cutting. Growth low and somewhat spreading. Has few thorns.

\section{Tea Roses}

MAMAN COCHET-The best of the tea roses; moderately hardy; rosy, coral-pink; large, exquisitely tapering buds, very fragrant; continuous bloomer.

WM. R. SMITH-Silvery white and pink toned with peach-pink flowers freely produced. Foliage is sparse but very healthy, bush branching; long, strong

\section{Hybrid Perpetual Roses}

This class do not require winter protection. They bloom very profusely in June and early July and again in the fall if properly pruned and fed.

MARSHALL P. WILDER-Deep dark red; large perfect flowers good for cutting; a vigorous grower; fragrant; hardy.

FRAU KARL DRUSCHKI-"Snow Queen." White American Beauty. Universally acclaimed the best white rose. A pure snow-white double flower, often 4 inches or more across and last a long time. Fine for cutting. Blooms almost continuously. Strong, vigorous grower, often $5 \mathrm{ft}$. or more in a season. It is best pruned moderately. Perfectly hardy.

GENERAL JACQUEMINOT- "General Jack" is one of the most popular red roses; bright crimson-scarlet, fragrant; perfectly hardy. Needs quite severe pruning. Good for cutting.

Gruss an Teplitz

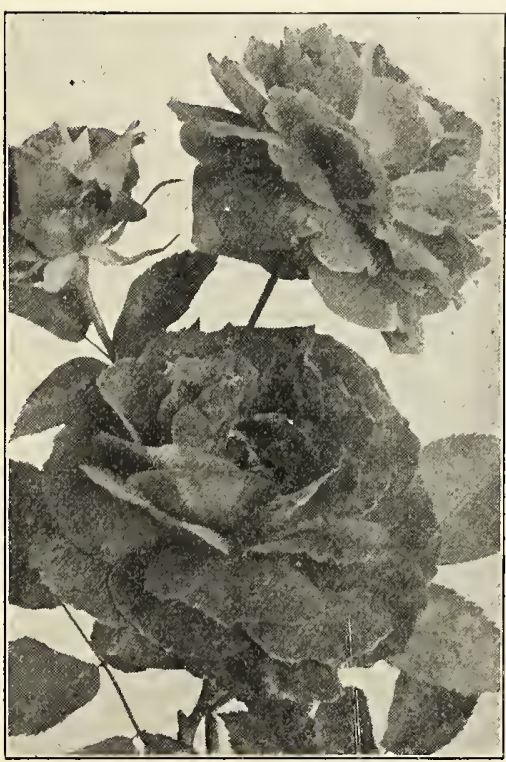
stems; one of the hardiest Teas.

PAUL NEYRONVery large, fragrant, bright fectly hardy and a strong grower.

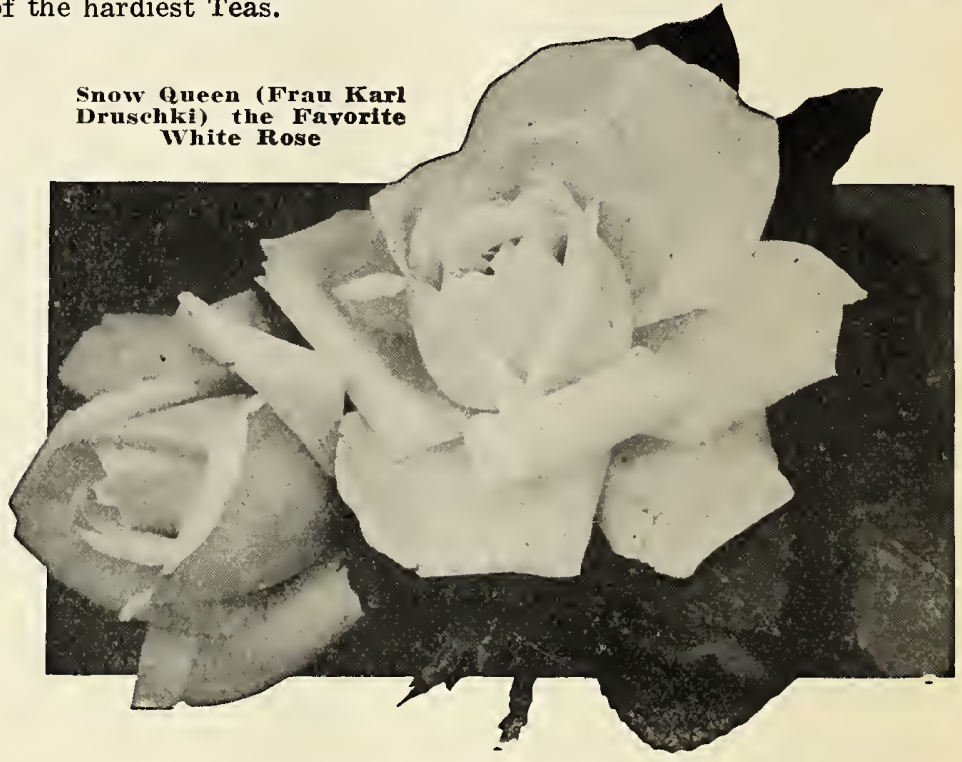

\section{Dwarf-Polyantha Roses}

These are perfectly hardy, constant and profuse bloomers in clusters nearly all summer, bushy growth of 18 to 24 inches; useful as bedding roses, to edge garden borders or walks, and in front of shrubbery masses. Can be transplanted to pots in fall to furnish winter blooms indoors. Prune lightly in late winter or early spring. ANNIE MILLER-Brilliant. shining pink flowers, larger than Baby Rambler. CRIMSON BABY RAMBLER-Bright crimson pink.

BABY DOROTHY - A beautiful shell pink.

\section{Hardy Rugosa Roses Will Thrive Everywhere}

The hardiest of all roses, very thorny, with shining, dark green, very wrinkled leaves; will grow almost anywhere, even on barren, wind-swept slopes and seashore sand. Seldom attacked by insects or diseases.

Excellent for hedges, for planting with other shrubs or as specimens. They require little attention except thinning out the dead wood and keeping them in bounds. CONRAD F. MEYER-Large, fragrant, silvery pink flowers, in June and occasional blooms thereafter. Should be planted not less than $3 \mathrm{ft}$. apart. Its 6 to $10 \mathrm{ft}$. growth may be trained over an archway or against a building.

ROSA RUGOSA ALBA-Large, white, fine-petaled flower, followed by attractive orange-red seed pods; a dense grower, 3 to $5 \mathrm{ft}$. tall.

ROSA RUGOSA RUBRA-Large, very fragrant. bright pink to deep carmine flowers, followed by orange-red seed pods. A dense grower, 3 to $5 \mathrm{ft}$. tall. 


\section{Good Plants Plus Good Care Bring Rich Rewards}

\section{Climbing Roses}

They are very hardy, resistant to insects and disease, vig. orous in growth, making canes $10 \mathrm{ft}$. or more in height, and adaptable to many uses-trained on a trellis, a porch, a house, over banks, on stakes 4 to $8 \mathrm{ft}$. high, or even allowed to grow at will as a rambling bush.

CLIMBING AMERICAN BEAUTY-Rose crimson flowers in profusion suitable for cutting. A vigorous grower, very free from attacks of insects and disease. Older canes should be pruned out each year.

DR. VAN FLEET-Pure apple-blossom-pink flowers, good for cutting. A very profuse bloomer.

SILVER MOON-Large, silvery white, with yellow stamens. Foliage glossy, dark green; very vigorous grower.

DOROTHY PERKINS-Double, shell-pink flowers in clusters; vigorous and dependable.

EXCELSA-Sometimes called "Red Dorothy Perkins"; far superior to the old Crimson Rambler. Radiant, bloodred double flowers in large clusters. Very vigorous and quite free from attacks of insects and disease.

GARDENIA-The buds are bright yellow, the flowers creamy with yellow centers; early, in small sprays; fragrant.

PAULS SCARLET CLIMBER-Bright, vivid scarlet double flowers in clusters of three to six. No other rose can compare with it in brilliancy of color.

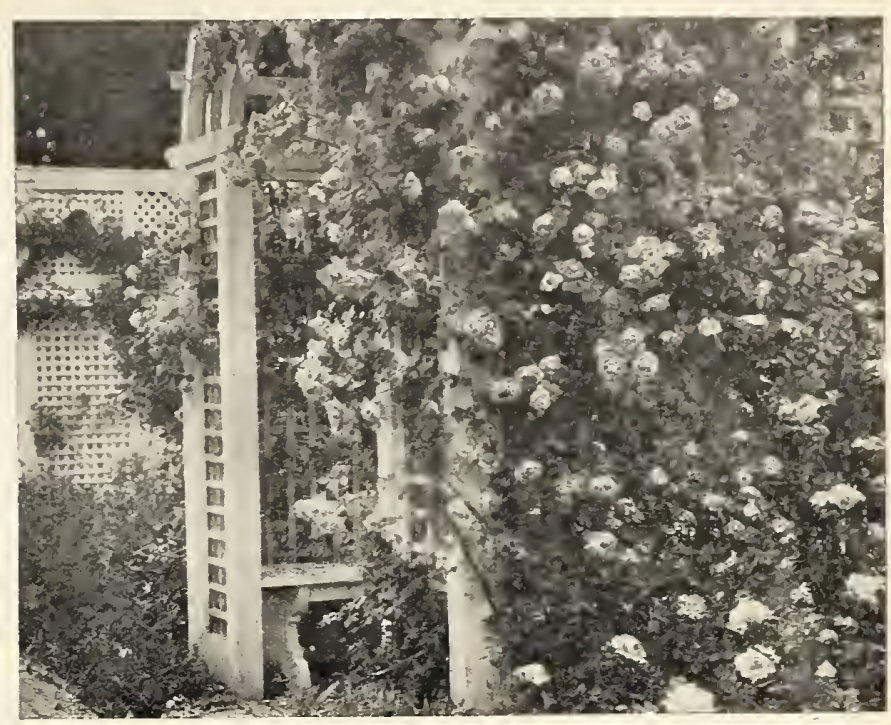

Climbing American Beauty Rose.

\section{Roses}

Of course you want roses blooming in your garden next summer. You can have them if you will do your part.

First. Select a location where the roses will have at least a half day's sunlight and where they will not have to compete with the roots of trees for food. Lay out the bed with the bushes about 10 inches from the edge of the beds and spaced $2 \frac{1}{2}$ to $3 \mathrm{ft}$. apart for the larger growers like the Hybrid Perpetuals, and 18 to 24 in. for Hybrid Teas. For a single row a bed about 18 inches wide is sufficient.

Second. Send us your order for our first class 2-yr. field grown plants.

Third. Prepare the beds at once. Dig the bed 18 to 24 inches deep, putting the good top soil to one side. If your soil is mostly clay, dig the bed 6 inches deeper and put a 6 inch layer of stones or crushed rock in the bottom. Fill in with good soil thoroughly mixed with well rotted manure. If your soil is quite gravelly or sandy, mix in some clay. One-third each of top soil, clay and rotted manure is a good mixture.

Fourth. When your roses arrive if you cannot plant at once, "heel" them in, i. e., dig a trench and spread out the bushes and cover them root and top. Pack the dirt closely about the roots and mound up the dirt 6 inches or more above the surface of the ground. They will then be ready to transplant when the weather is favorable.

Fifth. Planting and Mulching-Do not expose the roots to drying sun or winds. Keep them well covered with damp earth, moss or bags. Dig a generous hole. Set budded roses so that the point where the bud was inserted is one to two inches below the surface. Set own-root roses, including the Climbers, about an inch deeper than they stood in "he nursery. Spread the roots carefully and tamp the dirt firmly around them. The tops will be cut back to not more than a foot before shipment. Water thoroughly if the ground is dry.

After Care. Keep the ground cultivated lightly, or use a mulch of peat moss or strawy manure. Feed the plants with bone meal worked into the soil or with liquid manure. Soak the ground thoroughly whenever the surface becomes quite dry. Prune in early spring. With strong growing varieties, cut back the larger canes to five or six buds or eyes, the weaker canes to 3 or 4 buds. With the smaller growing varieties leave 3 to 4 buds on strong canes and 2 to 3 on weak growths. Climbing roses are pruned just after blooming, cutting out old wood according to growth and tie up the new canes to the position desired.

Winter Protection. Before the ground freezes put a mound of dirt about 6 inches high around each plant. After freezing, cover with dry leaves or heavy litter of manure and straw. Remove this soil and mulch in the spring.

To prevent mildew and black-spot, dust every week or two as soon as the leaves put forth with 9 parts dusting sulphur and 1 part of powdered lead arsenate. To kill plant lice or aphis, spray with a nicotine solution like Black-Leaf-40.

"My vines and roses sure are nice They are blooming this summer, and I don't think I ever saw any nicer roses than they are."-Fannie King, Murray Co., Okla.

"I never had such grand looking roses before, and if they live and bloom we'll be singing your praises every time we bury our 'noses' in them to smell the fragrance, in which I think rcses excel all else."-Myrtle M. Stafford, Washington Co., Arkansas.

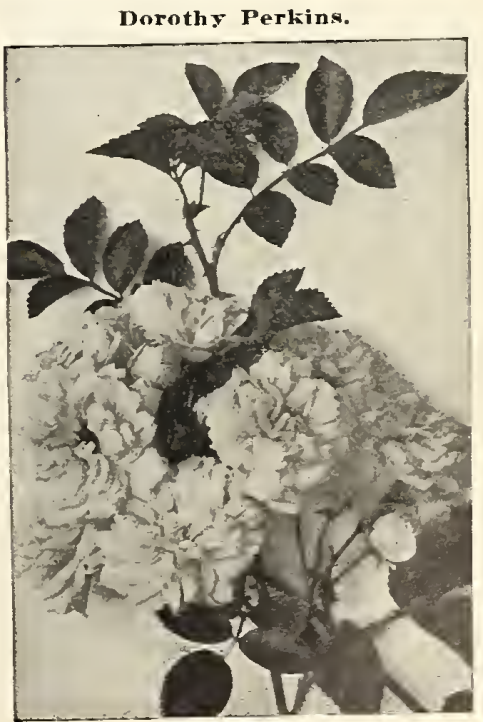




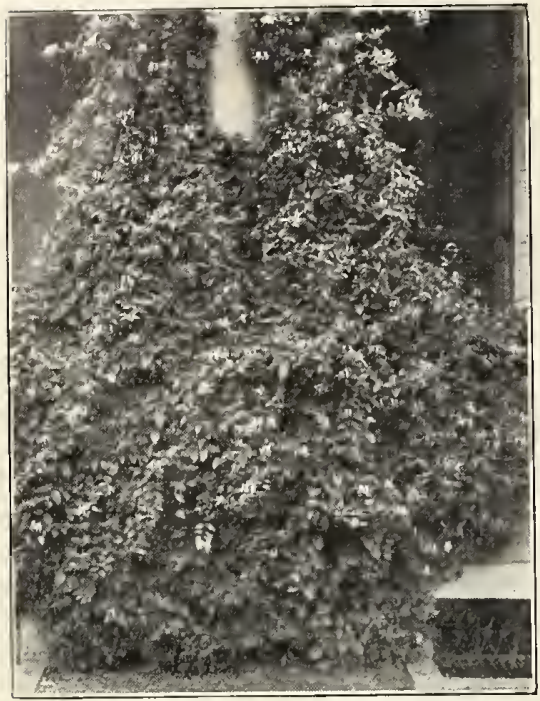

Hall's Honeysuckle

\section{Climbing Vines}

Vines add so much to the beauty, grace and comfort of the home, it is strange they are not used more freely. They are invaluable for toning stiff angles of buildings, to provide shade and flowers over veranda or trellises, to prevent washing on steep slopes and banks, and to cover unsightly objects.

If planted next to walls, dig the soil out for 18 to 24 inches and fill in with good dirt. In such locations they are likely to need watering and fertilizing with bone-meal or well-rotted manure.

Climbing vines are pruned after blooming to remove dead wood and straggling growth, except that vines with ornamental fruit like Japanese Clematis, Virginia Creeper, etc., are cut back severely in the spring.

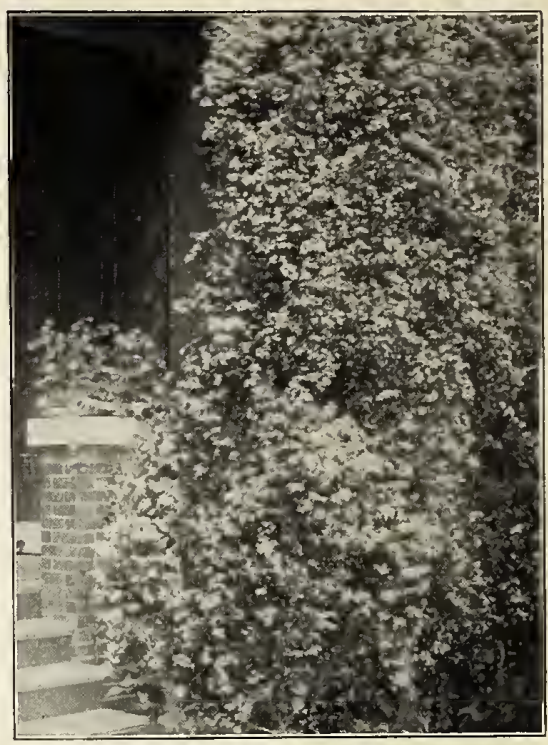

Japanese Clematis
BOSTON IVY (Ampelopsis Tricuspidata Veitchi)-Bright attractive foliage turning to crimson in the fall; clings firmly even to smooth surfaces; hardy.

VIRGINIA CREEPER (American Ivy) (Ampelopsis Quinquefolia)-Beautiful, large five-lobed leaves turning brilliant crimson in fall, contrasting handsomely with its blue berries.

ENGLISH IVY (Hedera Helix)-Has attractive evergreen leaves, waxy, dark green. Clings to walls or trees. Not hardy north. Does best on north or east side of house.

CLEMATIS, JAPANESE (C. Paniculata)-Bright foliage with countless little star-shaped white flowers, very fragrant; blooms late. Support on trellis; grows ten to fifteen feet.

CLEMATIS, JACKMANI-Violet-purple blooms in July and August.

HONEYSUCKLE, HALL'S (Lonicera Japonica Halliana) Shiny green foliage; pure white, trumpet shaped flowers with sweet perfume; used to cover fences, embankments, arbors, etc. Blooms in late fall. Hardy. Thrives in heavy soil. Endures shade.
TRUMPET FLOWER (Bignonia Radicans) - Long, trumpetshaped orange-scarlet flowers, beautiful light green foliage. Especially good for covering walls, fences and embankments.

W I S T E R I A, JAPANESEBeautiful foliage, long clusters of pear-shaped, purple flowers; makes a heavy vine; grows very tall.

HONEYSUCKLE, SCAR L E T TRUMPET (Lonicera Sempervirens); orange-scar le $t$ flowers $1 \frac{1}{2}$ to 2 inches long.

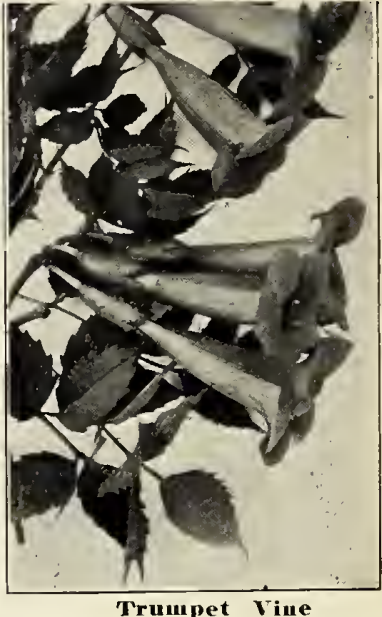

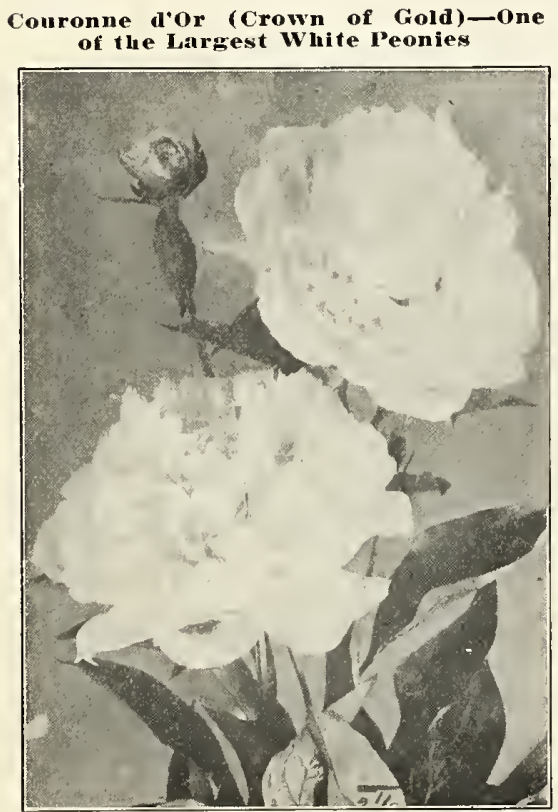

\section{Peonies}

Peonies rival the rose in perfection of form and color. The flowers are lasting and some varieties are fragrant. They are very free from disease and insect pests. Perfectly hardy and easily grown. All they ask is a good soil and a winter mulch. The blooms increase in size and number with age. They are permanent and do not have to be moved or transplanted. They are used singly, as specimens, in massed beds, or in perennial or shrub borders.

Can ship in September on to May 1st.

Peonies should be planted from 18 to 36 inches apart, and set so that the eyes will be not more than two to three inches below the surface of the soil. Bone meal is the best fertilizer.

\section{WHITES}

COIRONVE llor-White with gold stamens and carmine tips. Late. FESIYI MAXIMA-White carmine tips at center. Very early. DUCHESS DE NGMoUrs-White, green tips at center. Fragrant. Mid

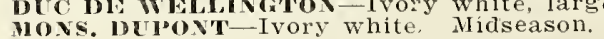

PINKS

DOHCHESTER-Pale pink, large, fragrant. Very late FIrIENIE VERDIER-Pink, large. Late.

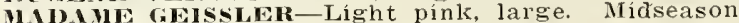

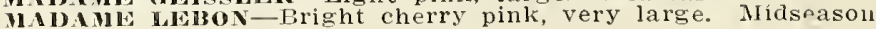

\section{REDS}

DEL ICHEI-Deep purple-crímson. Late.

Flid Crilliant ruby-red, large, fragrant. Midseason Mlissonier-Brilliant reddish purple, Midseason.

IIR

II

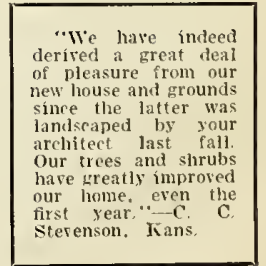




\section{Beautiful Grounds Need These Plant Materials \\ Spring Bulbs \\ Hardy Perennial Plants}

Plant after frosts are over, in rich, well-drained soil. It helps to set each bulb on a handful of sand. Don't put manure in contact with bulbs.

CANNAS are most effective when used in masses with varieties of a kind grouped together, tall growers at the back, lower growers in front. Set 4 to 5 inches deep, 18 to 24 inches anart. For a round bed $7 \mathrm{ft}$. in diameter, set 18 inches apart, one in the center, six in the inside row and twelve in the outside row.

GLADIOLUS are easily grown, have a great range of color and as cut flowers keep for a week. They mature in about 90 days so that successive plantings provide blooms from July till frost. Plant in beds, in rows, or in clumps among perennials. Plant 2 to 4 inches apart, 4 to 5 inches deep in heavy soil and 7 to 8 inches deep in light soil.

DAHLIAS should be set about 4 inches deep and 4 to 5 ft. apart. When they have made their first leaves cut away all but one or possibly two strong shoots. When a foot high tie to a stake. Side shoots can be made to put forth by pinching off the top.

\section{Fall Bulbs}

Hyacinths, Tulips, Narcissus, Jonquils, are set 4 to 6 inches apart. Cover Tulips 4 inches deep; other kinds 5 inches. Plant in October or November in deep, well-drained rich soil. Mulch with straw or leaves 4 to 6 in. after ground is frozen. Remove mulch carefully in spring before warm weather.

\section{IRIS}

Sometimes called Hardy Orchids because of their exquisite coloring.

Iris will thrive in spite of neglect where other flowers fail but does best on fertile well-drained soil. May be planted in the spring but give better results and more bloom first season if set in the fall from August until first frost.

Put the crown of the root about two inches below the surface. For planting along borders or in masses they are spaced 8 to 10 inches apart. inches apart in rows 3 feet wide.

\section{VARIETIES}

Named in Order of Blooming

American Black Prince-Dark furplish blue; blooms nearly 30 days. beginning almost a month ahead

Perfection-Purple and lavender; very beautiful.

Queen of May-Lilac with rose tint.

Sans Souei - Canary yellow and crimson brown.

Celeste-Pale azure blue, large.

Madame Chereau - White frilled with clear blue.

Flavescens-Creamy white; sweet scented.

Orientalis-Intense blue, narrow leaves.

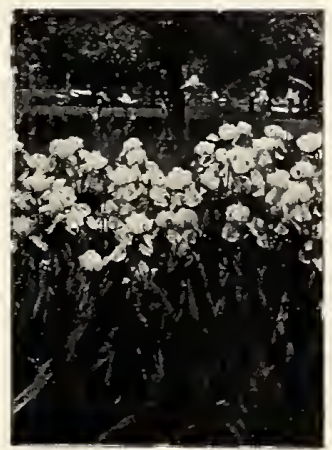

\section{Other Hardy Perennials} CoNvallaria MAJALIS (Lily of the Valley)-Plant in spring
in partial shade.

LILIUM AURATUM (Gold Banded Lily)-Plant in spring, 18 in. apart, 6 in. deep. Flowers in July and August.

LILIUy CAXDIDUM (Madonna Lïy)-Plant in fall, 18 in. apart, 4 in. deep. Flowers June 15 th to July 15 th.

IRIS KAEMPFEIR I (Japanese I IRis)-Various colors, June 15 to 2 uly 15 th. 2 to $3 \mathrm{ft}$. stalks. Plant 12 to 18 inches apart. 2 inches deep.
These plants will bloom for you abundantly the first summer and in succeeding years without replanting, although some varieties need to be taken up and the roots divided after several years.

Plant in masses bordering driveways, fences, or the lawn; along shrub borders, or in the garden. Our Landscape Department will gladly help you plan your plantings upon request.

lt pays to mix in thoroughly well-rotted manure or bone meal in good soil that has been deeply dug. The ground should be kept well stirred and soaked with water occasionally during the hot dry weather. Apply a covering of manure in the fall and mix it into the soil in the spring.

In northern states, varieties that bloom late in the season are better transplanted in the spring.

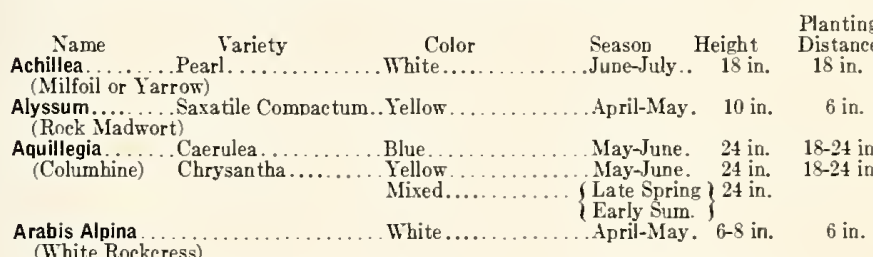

(White

Asters

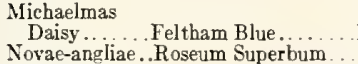

Baptisia Australis

(False Indigo)

Bellis Perennis.......

Campanula ........Carpatica........... B

(Bellfower)

Campanula Media.

(Canterhury Bells)
Coreopsis.............................

(Golden Daisy)

Chrysanthemum...Hardy Garden. . . .

Chrysanthemum

Maximum..... Alaska.
(Shasta Daisy)

(Larkspur)

Belladonna

anthus.

Bellamosa

(Pinks)

Plumarius....

Dianthus

Barbatus

(Sweet
William)

Digitalis....
(Foxglore)

Newport Pink

Nigricans.

Giant Hyhrids

(Plain tain Lily)

Gaillardia

Caerulea.

(Blanket Flower)

Grass

Gypsophila

Grandiflora..

(Bahy's Breath)

Hemerocallis....Flava

(Yellow Day Lily)

ollyhocks

Lathyrus

latifolius

(Perennia

Lupinus

grandiflorus.

(Lupine)

April-May. 6-8 in.

6 in.

Lychnis Viscaria ...Splendens .

(German Catchfly)

Myosotis.......Palustris ...

apaver

Orientale ... Hyhrids.

(Poppy).

Phlox paniculata

Richard Wallace

Miss Lingard.

Rheinlander. .

Rijnstroom.....

Phlox subulata... Alha

Ground or

Mioss Pink).. Rosea...

Platycodon

Grandiflorum.

(Ballonn Flower

Rudbeckia

(Golden Gilow)

Py rethrum.... Hyhridum

(Pain ted Daïsy)

Sedum...

(Stonecrop)

Blue

Red...
Blue.

White

Blue.

Mixed..

Yellow.

Mixed..

August.... 3-5 ft. $\quad 18-24 \mathrm{in}$.

April in to

June...... $3-6$ in. $\quad 6$ in

July-Aug. . 24-36 in. $24 \mathrm{in.}$

June-July.. 24 in. 24 in.

Sept.-Oct. 36 in. 24 in.

White..

July-Aug .

24 in.

18 in.

Light Blue

Dark Blue.

Mixed.

Pink.

Summer

48 in. 24-36 in

. 48 in. 24-36 in.

$\begin{array}{rrr}48 \text { in. } & 24-36 \text { in. } \\ \text { ummer... } & 8 \text { in. } \quad 12 \text { in. }\end{array}$

Rose

Red....
Mi.sed

Mised...
Various

May-June

May-June

May-June
June-July

18 in.

12 in.

Blue.

Jul

18 in.

12 in.

Yellow.

24 in.

12-18 in.

summer

24 in

12 in

May-June $24-36$ in

12 in.

White.

Jure.

30 in

12-18 in

Mixed.

July-Aug. . 36-48 in

24-36 in

White
Pink.

July-Aug

$4-8 \mathrm{ft}$.

$8 \mathrm{ft}$.

May 15-

Blue
Pink

Rosy-Red

June 15.

May 15-

$2-5 \mathrm{ft}$.

18-24 in.

Blue

8 in.

$18-24$ in.
$12-18$ in

Crimson.

May-June

Various

Summer.

White,

Salmon, Claret Eye.

Carmine, Claret Eye

Bright Crimson Pink

White.....

Pink

April-

May 15

Blue.

Yellow

Mixed...

July, Aug.
Sept.
July-Aug.

36 in.

6 in.

(Cornflower Aster)

May-June

.

12 in.

12 in.

12 in.

12 in.

12 in. 


\section{Evergreens}

\section{A Few Evergreens Correctly Placed Produce Distinctive Effects}

Evergreens never drop their foliage and hence do not go into a dormant condition. Necessarily they must be transplanted with a ball of earth around the roots. Frequent transplantings with root prunings are necessary in the nursery row to develop a mass of fibrous feeding roots within the ball. Neosho evergreens are carefully hand dug, the balls of earth wrapped with burlap.

The specimens offered below are graded by height measuring from the level of the ground to the tip of the specimen. In a few instances they are offered by spread. Our guarantee is to deliver good, thrifty specimens that will meet your approval on arrival. There is positively no guarantee as to growth.

\section{When to Plant Evergreens}

The two seasons for planting, fall and spring, are equally satisfactory, the fall season running from September 15th to November 15th, spring from April 1st to June 1st. These dates may vary slightly with different seasons, and also with location, according to whether one is situated in the extreme northern or southern zones.

\section{Adaptability of Evergreens}

Most all Evergreens do well in both sun and shade and readily adapt themselves to a wide variety of soils and climatic conditions. In general one will find the American types of Arbor Vitae (Thuya Occidentalis) the hardier from Kansas City north. Both types do well in the intermediate zone, while the Chinese types (Biota Orientalis) are more satisfactory for southern planting where they have to withstand the hot summer suns and protracted drouths. All the specimens listed below are

COMMON CHINESE ARHOR VITAE (Blotg Orientalis) - A fast growing Evergreen which has the typical pressed foliage of the Arbor Vitae family, branches uprigh and parallel. Inclined to be rather open but can be made compact by shearing.
Color bright green. Seedling tyfe.

BAKER'S PYRAMIDAL ARBOR VITAE (Biota orientalis Pyramidalis)-A very well-formed, compact, uniform, pyramidal tree. It grows broeld at the base and tapers to a point at the top. Deep green in color. Does not require shear-
ing. Desirable for accent points at entrances and in formal work.

CHINESE COMPACT ARBOR VITAE (Blota Orientalis Compaeta)-Compac dwarf type of the Biotas, the foliage being finer and more graceful than the plain Chinese. Color deep green.

BERCKMAN'S GOLDEN ARBOR VITAE (Biota Orientalis Aurea Nama)-Form and foliage very similar to Biota Compacta but the tips carry a conspicuous bright golden color. Very attractive. Desirable in groups, as specimens or in foundation plantings where added color is desired.

MAYHEW'S GOLDEN ARBOR VITAEA beautiful light green type of compact Biota Orientalis with the golden tip but
not so pronounced as on the Berckman's not so

ROSEDALE ARBOR VITAE (Biota Orientalis Hybrid)-The foliage is quite different from the otlier Biotas, resembling more a cross between the Arbor
Vitae and Juniper. It is a bluish color Vitae and Juniper. It is a bluish color
during the winter, new growth in the spring coming out bright green. It is compact, globe shaped.

AMERICAN GLOBE ARBOR VITAE (Thuya occidentalls Globona)-A wellknown, very dwarf, compact, globe-
shaped type of the native species. The shaped type of the native species. The spread is as broad as the helght. Sel-
dom gets over 3 to $4 \mathrm{ft}$. Maintains its

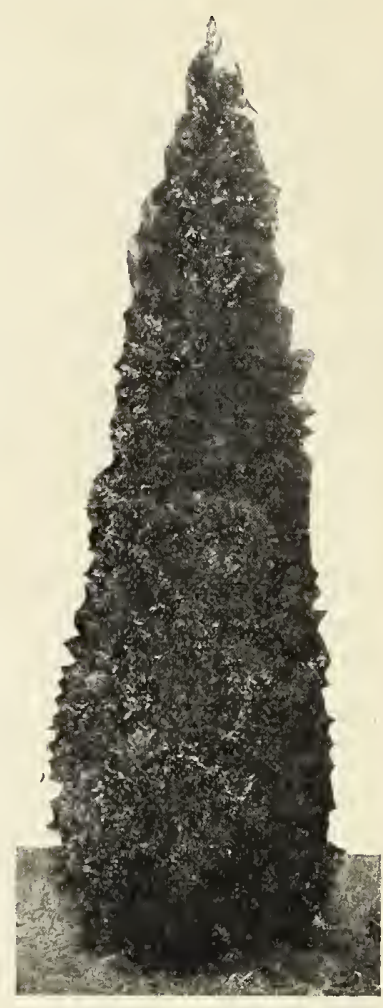

American Pyramidal Arbor Vitae

globe shape without pruning. Dark green. Splendid for tubbing and entrances. Stands severe temperatures. Measured by spread of specimens.

MERICAN PYRAMIDAL ARBOR VITAE (Thuya occidentalis Pyramldalis)-The same type of foliage as the American Globe but pyramidal in shape and grows to a height of 12 or $15 \mathrm{ft}$. Is often used for sentinels at entrances. Good for formal effects. Keeps its y y ramidal form without pruning. Dark green. Stands severe temperatures.

PFITZER'S JUNIPER (Juniperus Chinensis Pfitzeriana)-This is a low spreading Juniper, very hardy, standing both very hot and cold temperatures. It is strikingly graceful, long plume-like branches, foliage a bright silvery green. May be trained in an upright form by staking a leader if desired. Measured by spread of specimens. 12-18 in. spread.

IRISH JUNIPER (Juniperus Hibernica) Juniper of formal habits. Grows to height of $15 \mathrm{ft}$. Foliage sage color or bluish green.

NORWAY SPRUCE (Picea Excelsa)-A Most widely planted and the hardiest of Most widely planted and the hardiest of
the Spruces. The branches are spreading and drooping. The color is very dark green, the rafid new growth each season being light green. Grows to a height of $40 \mathrm{ft}$. Used mostly as a specimen. Not suitable for foundation planting.

RETINOSPORA PLUMOSA-A handsome, feathery, medium growth Evergreen shape. Bluish green, lace-like foliage. suitable for groups or foundation plantings the exception of Norway Spruce.

One should bear in mind that it is not the Ireezing that hurts Evergreens, but

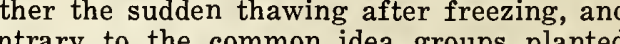
n the north side are less susceptible to injury than those planted on the south.

\section{Planting Instructions}

Plant as soon as possible after receiving hipment. As soon as received, unpack, suberge the earth ball in a tub of water for 30 inutes. Do not stand in the sun, but place cool, shady place out of the wind. Prepare soil well. Dig holes several inches wider ball. Set the trees straight slightly deeper than they stood in the row. Leave the burlap around the all but cut the strings after placing in . Tramp the dirt firmly around the cuple of pails of water. Fill the balance of the hole with loose dirt. They should be kept ell watered throughout the summer, cultivating the surface for a foot or eighteen inches round the trees. Do not put stable manure in the holes when planting. Loose straw or wellrotted leaves used as a mulch on top of the round make a good fertilizer and help protect them against winter injury.

EUONYMUS JAPONICA-A fine broad leaved upright evergreen plant with dark shiny, green foliage similar in appearance to Boxwood, though of more rapid growth, of moderate size and rather compact growth. Hardy as far north as Southern Missouri. Succeeds in almost any situation. Can be sheared to any desired form.

BELIA GRANDIFLORA-A very pretty shrub of unusual value. Blooms profusely from July to Sertember. Leaves glossy green turning coppery red in the fall; flowers tube-like, about an inch long, white on inside, delicate pink out; fragrant. Holds its foliage all winter as far north as Tulsa. Deciduous farther north but hardy as far north as Kansas City.

APANESE NANDINA (Nandina Domestica) - A very handsome shrub of moderate size and rather slow growth Leaves light green tinged with red in summer, turning to vivid red during the fall. The flowers are white, small, but in good sized erect panicles followed by bright crimson berries. Particularly striking in the fall with the bright red berries and darker red foliage. Not very hardy; would require winter protection north of Neosho.

PHotiniA-A large, broad-leaved, semievergreen of rounded form. Holds its foliage all winter as far north as Tulsa. Leaves drooping, 6 or 7 inches long, dark green upper surface, glossy, turning vivid red in the fall. Blooms in profusion in early spring, small white flowers in broad clusters 6 or 7 inches broad. 


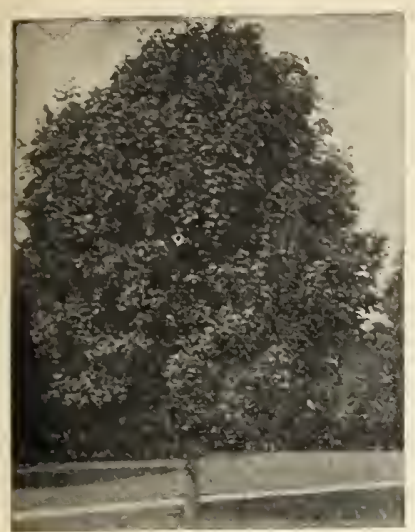

Norway Iaple

\section{Trees For Shelter, Shadeand Beauty}

Trees help to make our outdoor living rooms for leisure or play. They are needed as backgrounds and to frame the house. They add to our pleasure with beauty of form, foliage, flower and fruit, as specimens, in groups and in combination with shrubbery.

As backgrounds they are placed well back of the house line. To frame the house they are planted at both ends forward of the front line of the house. Along straight drives they are set not less than $35 \mathrm{ft}$. apart, alternately, and 5 to $10 \mathrm{ft}$. from the edge of the driveway. Along curved roads or paths they should be in groups rather than in lines.

ASH, GREEN (Fraxinus Viridis) - Shapely, rou nd headed tree with slender, spreading branches; rapid growing; 50 to $60 \mathrm{ft}$.

ASII. WHITE (Fraxinus Amerieana) - Quick growing with broad, spreading for street planting; grows over $60 \mathrm{ft}$.

BOX ELDER or ASH LEAVED MAPLE (Acer Negundo)-A rapid-growing, spreading tree, 30 to $60 \mathrm{ft}$., which endures dry soil. Often used for windbreaks.

CATALPI, WESTERN (Catalpa speciosa)-Has bright green leaves and beautiful white or yellowish-white, fragrant ft. up.

ELI, A MERICAN (Ulmus Americana)-This is a majestic and graceful tree. Valuable as specimens near house and as street trees; 80 to $100 \mathrm{ft}$; yellow fall foliage.

ELM, SIBERIAN (Ulmus Pumila)-A very fast grower, enduring drought and extremes of temperature, very free from diseases and insect injury. Leaves out early in spring and sheds them late in fall. Leaves smaller, branches more slender than American Elm. Hardier than Chinese Elm (Ulmus Parvifolia).

LINDEN, AMERICAN (Tilia Amerieana)-Basswood or Whitewood. A stately tree with large shining leaves and yellow flowers which attract honey bees. A rapid grower to $60 \mathrm{ft}$. A good street tree.

MAPLE, HARD or SUGAR (A. Saccharum)-Slow growing but long-lived with beautiful foliage turning red and yellow in early autumn. Excellent for shade and lawns, also as

MAPLE, NORWAY (Acer Platanoides)-Handsome, low-headed, compact growing with broad, deep green foliage holding its color late into fall. Valuable for lawns and parks; 30 to $60 \mathrm{ft}$.

MAPLE, SILVER or SOFT (Acer Dasycarpnm [Saccharinum])Very fast growing, valued for producing quick shade. Over $60 \mathrm{ft}$

oAK, PIN (Quercus Palustris)-Very desirable for lawn, street and park planting. Grows rapidly, 30 to $60 \mathrm{ft}$. Branches are drooping in form with age. Foliage is deep green, turning to scarlet and yellow in fall.

Poplar, Caroliva (Populus Eugenei)-Very rapid growing, healthy, hardy tree with large, glossy, pale to deep green leaves; pyramidal in form; grows 25 to $40 \mathrm{ft}$. Useful for temporary results.

POPLAR, Lombardy (Populas Nigta Italica)-A narrow steeple-like tree, strikingly picturesque, attaining a height of $60 \mathrm{ft}$. or more; valuable as specimens, as screens, in mixed plantings for contrast with broader trees, and behind buildings. Rapid growing.

SYCAMORE (Platanus occidentalis)-Called also Buttonball or Button wood.

TULIP (Liriodendron Tulipifera)-Sometimes called Whitewood or Yellow Poplar. A large, magnificent tree, $60 \mathrm{ft}$. up. Glossy green foliage turns yellow in fall; tulip-like, green ish-yellow flowers with orange center appear in June.

WEEPING WILLow, WISCONSIN (Salix Blanda)-A hardy tree, 25 to $40 \mathrm{ft}$., with slender, drooping branches.

\section{Nut Trees}

BLACK WALNUT-Thrives in nearly every state. The nuts of the following budded or grafted varieties are of ex-

OHIO-Early bearer. Nuts medium to large and thin shelled.

THOMAS-Grows larger than ordinary Black Walnut. Nut is very large.

ENGLISH WALNUT-The Franquette is doing well in the Eastern, Middle and Southern states, in Oregon and Wash ington. It makes a large ornamental tree and bears a medium to large fine flavored nut with fairly thin shell at Lancaster, Pennsylvania, bore two bushels of fine nuts.
PECAN-Grows wild from southern Indiana and Clinton, Iowa, to the Gulf coast on a wide range of soils. Northern varieties such as Butterick and In Indiana are adapted
for Ozarks and North. Southern varieties, Stuart, Money-

\section{Small Trees}

ASH, MOUNTAIN, EUROPEAN (Sorbus Aucuparia)-Hardy tree 20 to $40 \mathrm{ft}$ tall, not particular as to soil, well suited to
rocky hillsides. Handsome foilage turning to orange-red in fall. White flowers in May are followed by red fruits which hang on all winter.

BECHTEL DOUBLE FLOWERING CRAB (Malus Ioengis) Grows 8 to $15 \mathrm{ft}$. Large, double, pink flowers resembling roses, and very fragrant, in late May.

DOGWOOD FLowering (Cornus Florida)-A large shrub or small tree, up to $20 \mathrm{ft}$. Valuable for white flowers in May; dark green foliage, bright red berries and brilliant autumn color. Grows in sun or shade.

MULBERRY (Morus Alba Pendula)-Teas' Weeping; hardy, beautiful weeping trees. Grafted on a straight trunk, the branches droop to the ground.

PLUM, PURPLE-LEAVED (Prunus Pissardi)-Valuable for purple foliage. Grows 10 to $12 \mathrm{ft}$. See page 36.

PLUM, DoUBLE-FLoweriNg (Prunus Triloba)-Valuable for double pink bloom. Grows 6 to $8 \mathrm{ft}$. See page 36 .

RED BUD (Cereis Canadensis)-10 to $15 \mathrm{ft}$. tall, with irregular head, with mass of small fink fowers before the leaves appear. Leaves are large, nearly round, dark green. Endures shade. Used as specimens or in border plantings.

UMBRELLA CATALPA (Catalpa Bignonioides Nana)-Roundheaded tree used for specimens and formal effects. Can be kept compact and symmetrical by late winter pruning.

Lombardy Poplars in Our Nursery

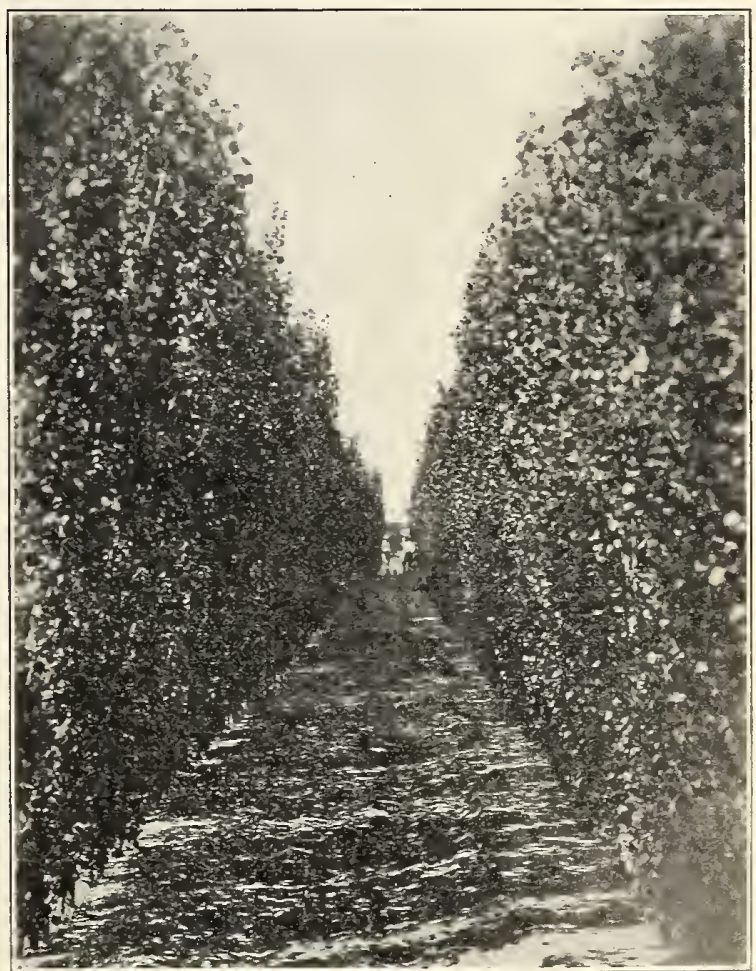




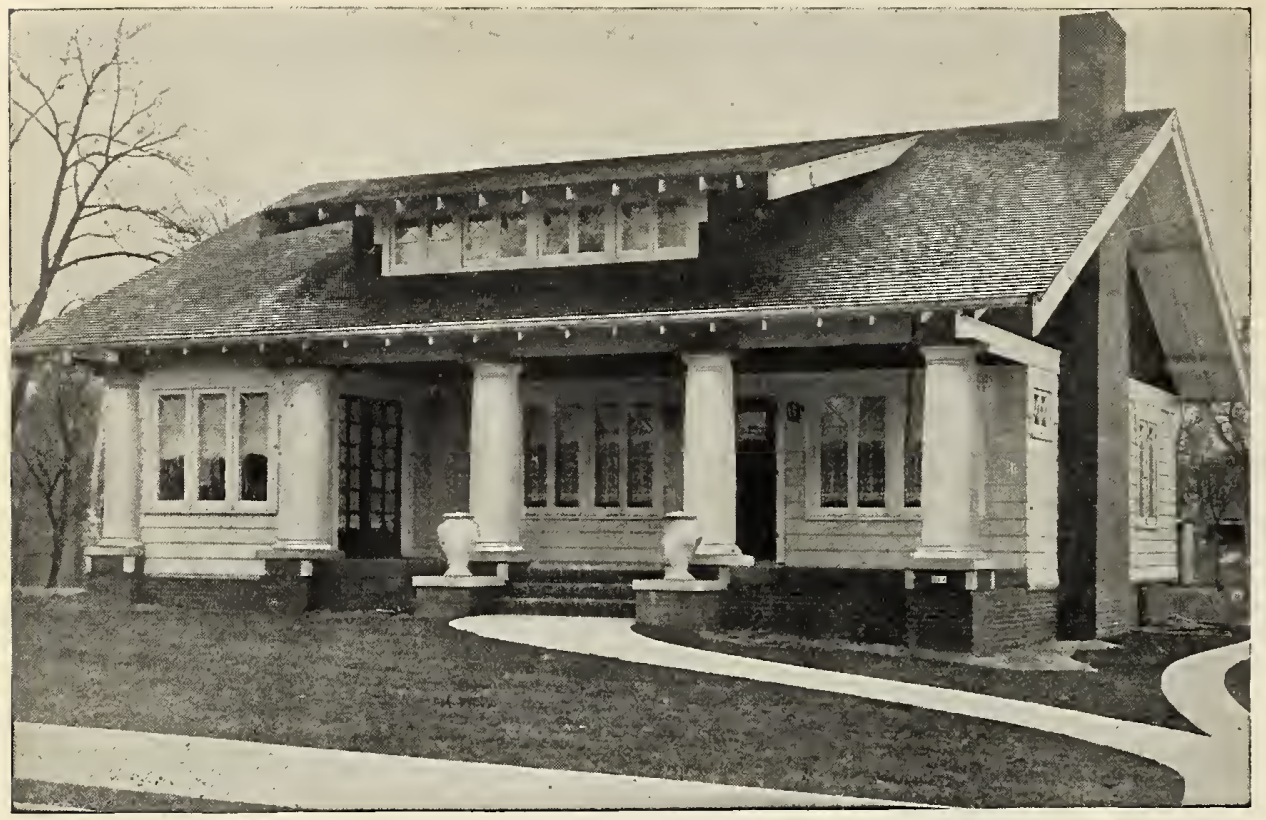

\section{LOOK AT THIS SAME HOUSE ON OPPOSITE PAGE!}

A striking example of increased attractiveness and enhanced value by the tasteful use of plant materials, and at comparatively little expense.

"The landscape service that you render is of the highest type. In addition the personal interest manifested through your representative has made it a pleasure for us to do business with you. Your abiltiy in landscaping and furnishing good in landscaping and furnishing good appreciated by those requiring your services."--Sam M. Degen, Pittsburg, Kansas.

\section{Pointers}

Many people love trees, roses and other plants for their own sake-for their beauty of form, foliage, flower or fruit-for shade and for protection. And rightly so. But these benefits may be enjoyed all the more when these plant materials are correctly placed so that a harmonious and pleasing effect is produced. You prefer others to say "what a beautiful home" rather than "what a beautiful shrub."

When you plan to beautify your grounds or someone solicits that privilege, it is well to discover the answers to such questions as the following:
How should walks and drives be laid out? Their purpose is utility and should be direct. Curves should have a reason or excuse, and be graceful in outline.

What three distinct areas should a home property have? A public, a private and a service area. (See page 25.)

How should a foundation planting be made? The taller shrubs in wider groups are used at the corners to scften the angles.

Pyramidal types are used to accent the entrances.
Leave part of the foundation exposed to view to give stability.

How should border plantings be arranged? The outline should be irregular-producing an effect of greater width to the property. The heights should be varied $t$ ) break the monotony of a straight regular surface. Knowledge of the habits of growth, character of foliage, and blossom hardiness, etc., are essential.

Be sure the plant will not outgrow its position. Norway spruce, for in- stance, are sometimes planted close to the house where they are soon out of place.

Why should flower beds be kept out of the lawn? They destroy the harmony of the scene, are too conspicuous, and make the grounds look smaller.

Why did an owner wish to change Spirea Van Houttei to Crimson Spirea at the corner of his house? Because he liked the crimson bloom, but did not realize its mature height is only about two feet.

\section{Table of Contents}

GENTR I IVFORUIT Page Causes of Failure to Grow......... 3 How To - Prepare ground - Handle Stock on arrival-Prune tops and roots-Set trees-Care for stock $r$ planting.

Introduction.

rietures of Nursery . . . . 12, $13,24,25,35$ FRUIT DEPARTMEN'

General Information

Adaptability of Varieties.

Buy by Diameter.

Cover Crops.

Distances to Plant.

Double-worked Trees.

Experiment Stations (Addresses)......

Fillers.

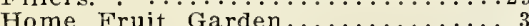

Intercrops.

Locations.

Profit Making.

Pruning.

Planting Plans

Rabbit Protection.

Soil Management.

Spraying.

Why Trees Fail to Bear.

$\ldots 2.23$

$26,27,28$

.28
Apples

Page

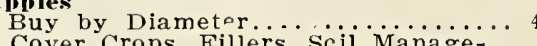

mer Crops, Filler.

ment, Planting.

Double-worked Grimes.

5 Varieties on One Tree.

Location.

Planting.

Pruning.

Spraying.

Varieties.

Apricots.

Crabapples.

Cherries.

Peaches.

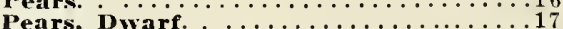

plums, Dwarf. $\ldots \ldots \ldots \ldots \ldots \ldots \ldots, 18,19$

Plums.

Nut Trees.

nall Fruits

Blackberries.

Currants.

Dewberries.

Gooseberries.

Grapes.

Raspberries.

Strawberries.
Giarden Roots

Page

Asparagus. . ...............21

Horse Radish. $\ldots \ldots \ldots \ldots \ldots \ldots \ldots \ldots \ldots \ldots \ldots \ldots \ldots \ldots$
Rhubarb. $\ldots \ldots \ldots \ldots \ldots \ldots \ldots$ ORN I MENTALS

Bulbs.

Evergreens. . . . . . . . . . . . 46

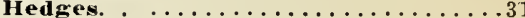

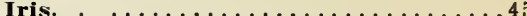

Landscape Service........ $33,34,35$

Peonies. . . . . . . . . . . . . . 4

Perennials. . ................. 45

Plantings, Formal and Informal.... 32

IRoses, Culture and Varieties...44, 43

Shade Trees. ...............

Shrubs

For Foundations. . ............

For Masses. ....................

How to Arrange..............

Making Your Plan............

ning. . .................

When to Piant............ $36,40,4$

Value of Beautifying............33

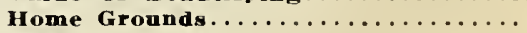

Vines. . .................. 


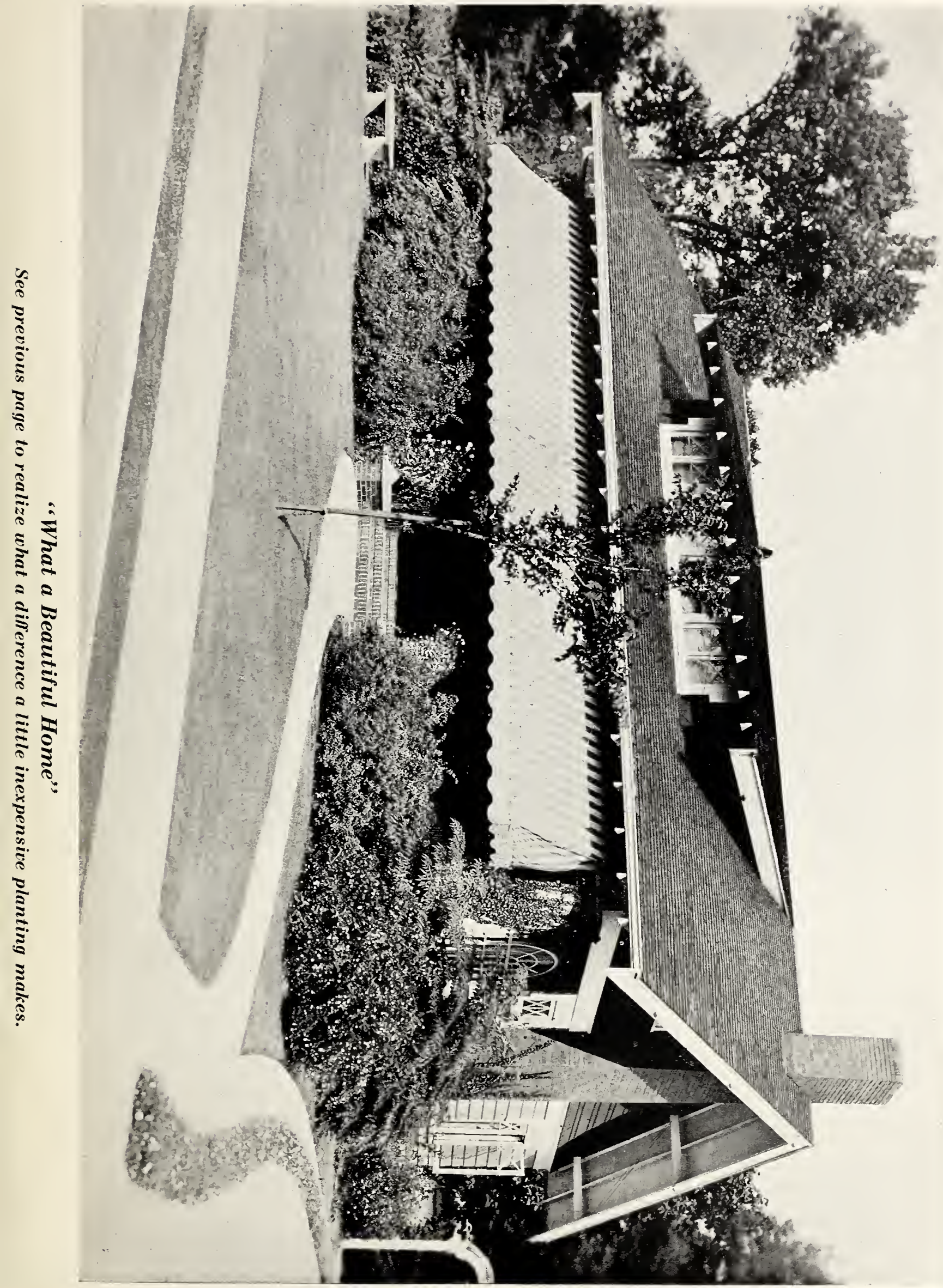




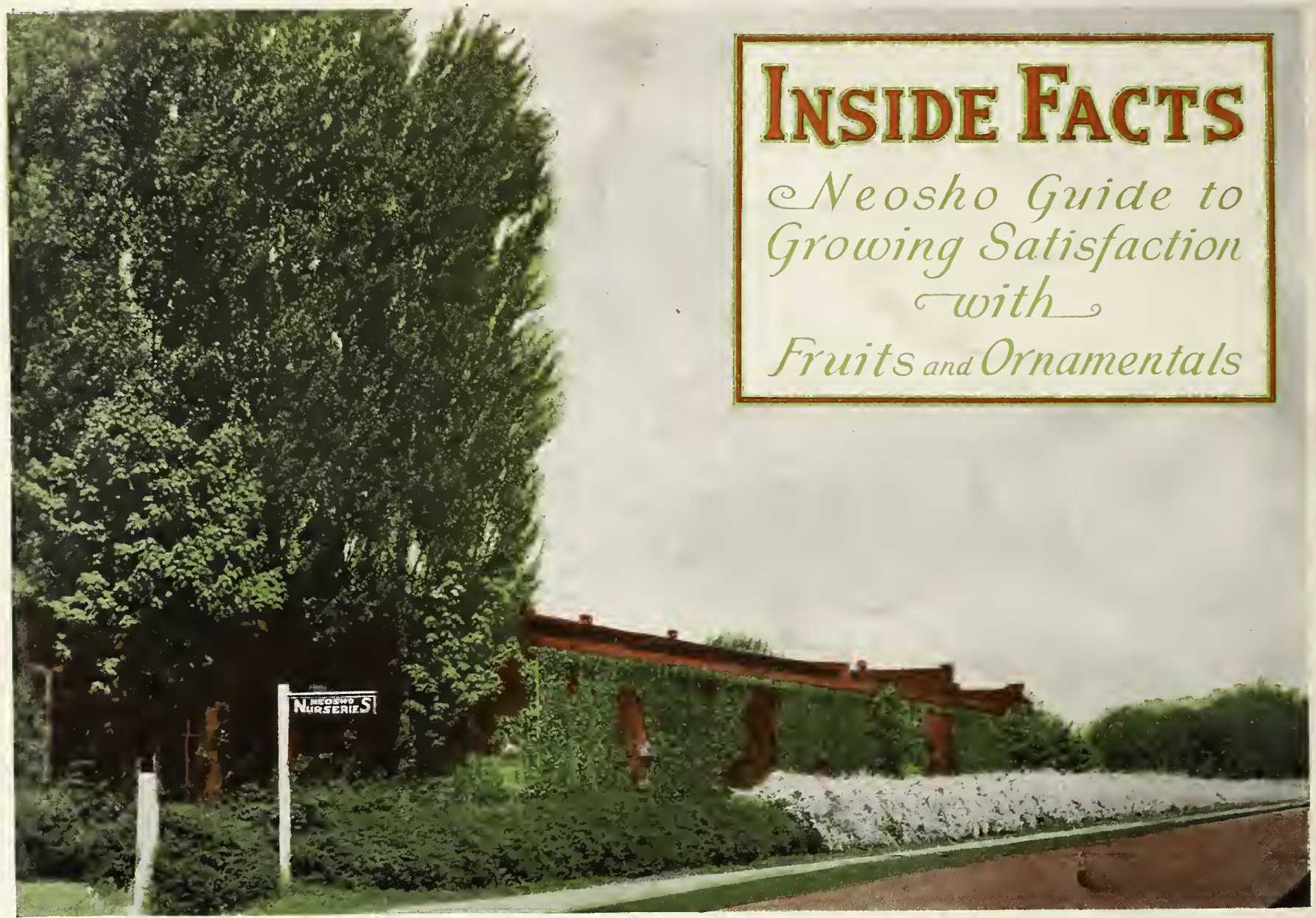

East view of Office and Packing House.

Showing Barberry and Spirea V. H. in full bloom, Lombardy Poplars, Boston Ivy and Sugar Maple.
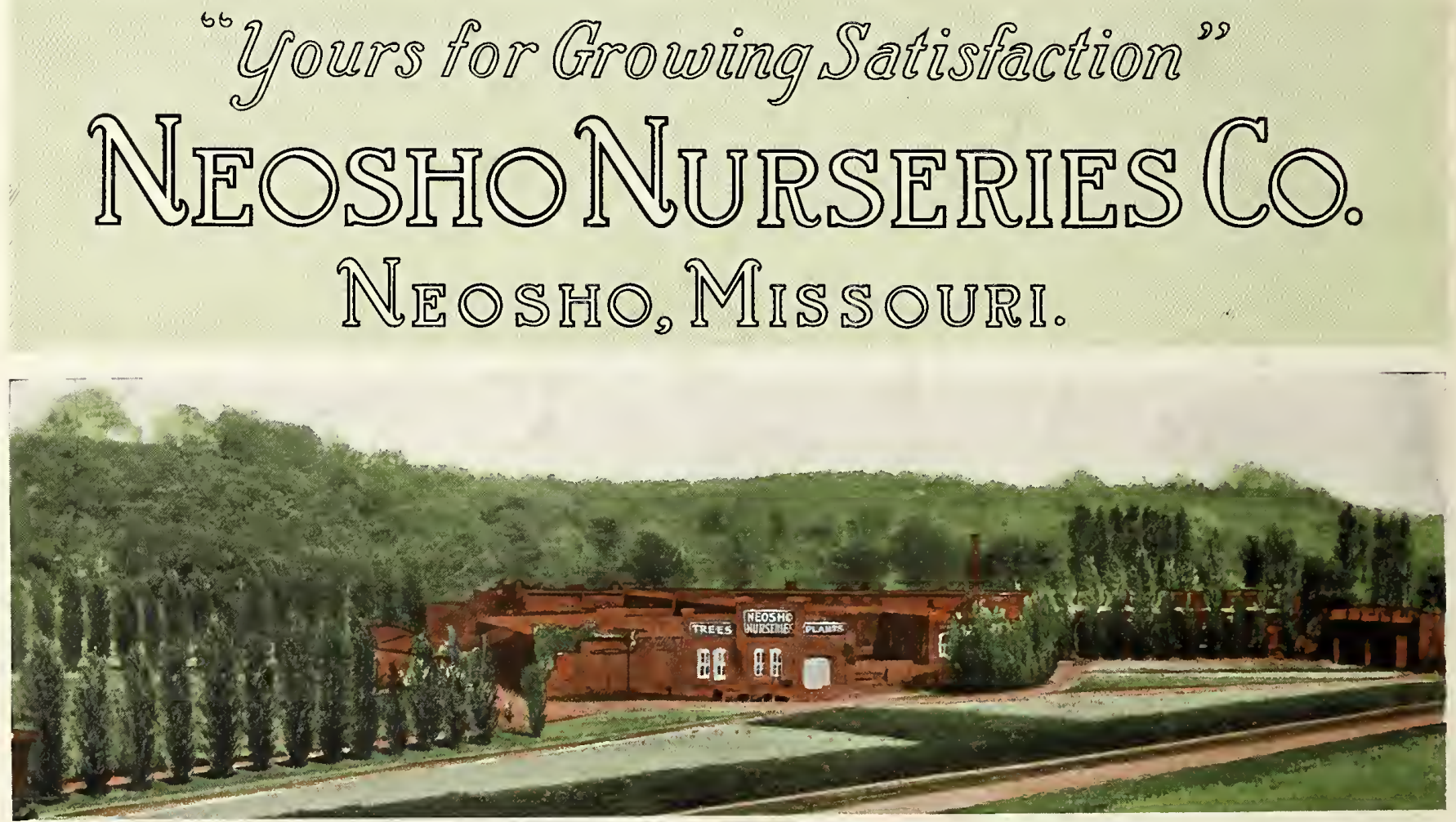

Track in foreground is Kansas City Southern Railway-Spur track comes to our door. 